University of Louisville

ThinkIR: The University of Louisville's Institutional Repository

$12-2017$

\title{
Norton Commons, Clifton, and social equity : a neighborhood, inter-neighborhood, and regional comparison of new urbanism and "old" urbanism.
}

Aaron J. Stephenson

University of Louisville

Follow this and additional works at: https://ir.library.louisville.edu/etd

Part of the Social and Behavioral Sciences Commons

\section{Recommended Citation}

Stephenson, Aaron J., "Norton Commons, Clifton, and social equity : a neighborhood, inter-neighborhood, and regional comparison of new urbanism and "old" urbanism." (2017). Electronic Theses and Dissertations. Paper 2875.

https://doi.org/10.18297/etd/2875

This Doctoral Dissertation is brought to you for free and open access by ThinkIR: The University of Louisville's Institutional Repository. It has been accepted for inclusion in Electronic Theses and Dissertations by an authorized administrator of ThinkIR: The University of Louisville's Institutional Repository. This title appears here courtesy of the author, who has retained all other copyrights. For more information, please contact thinkir@louisville.edu. 


\title{
NORTON COMMONS, CLIFTON, AND SOCIAL EQUITY: A NEIGHBORHOOD, INTER-NEIGHBORHOOD, AND REGIONAL COMPARISON OF NEW URBANISM AND “OLD” URBANISM
}

\author{
By \\ Aaron Stephenson \\ B.A., University of Kentucky, 2007 \\ M.A., Spalding University, 2012

\begin{abstract}
A Dissertation
Submitted to the Faculty of the

College of Arts and Sciences of the University of Louisville in Partial Fulfillment of the Requirements

for the degree of
\end{abstract} \\ Doctor of Philosophy \\ Urban and Public Affairs \\ Department of Urban and Public Affairs \\ University of Louisville \\ Louisville, Kentucky
}

December 2017 

NORTON COMMONS, CLIFTON, AND SOCIAL EQUITY: A NEIGHBORHOOD, INTER-NEIGHBORHOOD, AND REGIONAL COMPARISON OF NEW URBANISM AND “OLD” URBANISM

By

Aaron Stephenson

B.A., University of Kentucky, 2007

M.A., Spalding University, 2012

A Dissertation Approved On

August 18, 2017

by the following Dissertation Committee:

Dissertation Co-director: David Imbroscio

Dissertation Co- Director: Cynthia Negrey

Committee Member: David Simpson

Committee Member: Jasmine Farrier 


\section{ACKNOWLEDGEMENTS}

I would like to thank my dissertation co-chair, Dr. David Imbroscio, for his role in the completion of this dissertation and his role in the program in general. It has been Dr.Imbroscio’s teaching which has most shaped my interest in urban social equity and his progressive localist views have had a significant influence upon the strategies proposed in this dissertation. Additionally, his patience as this dissertation has undergone many overhauls is greatly appreciated. My co-chair, Dr. Cynthia Negrey, has been an enormous help methodologically, both in refining technical aspects of the study and in spotting more efficient and complete ways of measuring social equity. The remainder of the committee, Dr. David Simpson and Dr. Jasmine Farrier, have shown great flexibility in meeting considering the shifting timetable of the study. They have also provided an additional layer of constructive criticism and offered wonderful input during the prospectus defense, which is reflected in this dissertation. As Department Chair, Dr. Simpson has gone above and beyond to make certain that I have access to departmental resources in completing my research.

There are additional faculty and students I want to thank as well as expressing my appreciation with the Department of Urban and Public Affairs in its entirety. Professor Carrie Donald, my supervising professor for Graduate Research Assistant duties, did an excellent job in terms of broadening the scope of my academic experience. While my first love is urban studies, doing research in labor law has opened up further 
opportunities. Additionally, Professor Donald became a great friend over the years. Unfortunately, Professor Donald passed away only a couple of weeks after the completion of my work with her. She will be greatly missed. While all of the students from the Department of Urban and Public Affairs have been wonderful, I particularly want to thank Craig Barham, Wes Grooms, and Emmanuel Frimpong Boamah. Whether it be recharging over lunch and conversation, fighting through the foreign language of statistics, working to increase student engagement, or having brainstorming sessions about various research possibilities, it has been great knowing that they have been there for me.

Finally, I would like to thank my family for the role they have played over the years as I worked to complete my doctorate. My father and stepmother, Robert and Kathy Stephenson, have provided a nice respite from my work life through our casual family dinner and game nights. They have shown a sincere interest in getting to know what I have been up to in my work while providing me with the opportunity to engage in spirited debates with compassionate conservatives regarding politics and policy. My partner, Audrey Chen, the love of my life for the past decade, has been supportive throughout the different stages of this process and has taken a great interest in the subject matter despite being outside of the field. She has also generously agreed to lend her editing experience to my cause by editing a portion of this dissertation and providing valuable editing advice. Last but not least, I want to thank my mother, Donna Chandler, who is one of my biggest fans. She has been a bedrock of unconditional love and emotional support my entire life. Regardless of how busy life can get, she is always there to encourage and cheer me on every step of the way. 


\begin{abstract}
NORTON COMMONS, CLIFTON, AND SOCIAL EQUITY: A NEIGHBORHOOD, INTER-NEIGHBORHOOD, AND REGIONAL COMPARISON OF NEW URBANISM AND “OLD” URBANISM
\end{abstract}

Aaron Stephenson

August 18, 2017

This dissertation examines two paradigms aimed at restoring urban vitality-grassroots neighborhood revitalization and New Urbanism. New Urbanism is comprised of progressive goals, but unfortunately the relevant literature suggests that these goals have not been achieved. As such, this study focuses upon the degree to which each of these paradigms, New Urbanism and grassroots revitalization, may impact social equity on a spatial level. This dissertation explores this through a comprehensive micro-level comparison of two neighborhoods in Louisville, Kentucky- Clifton and Norton Commons. Clifton is an activist urban neighborhood that has been revitalized in recent decades, to become one of Louisville’s most vibrant urban neighborhoods. Norton Commons is in many ways the prototypical New Urban community, in terms of affluence, suburban location, and density.

This dissertation focuses upon spatial social equity specifically as it relates to providing access to daily essentials for people of all income groups. Previous research on New Urbanism’s relationship with spatial social equity can be pieced together looking at things such as housing costs, location within metropolitan areas, and to some extent, business presence. This research is important because of its complete synthesis 
of all elements of spatial social equity, and the resulting findings. The findings ultimately question New Urbanism's ability to address spatial social equity, given its weak performances in the following areas: access to affordable housing, consumer goods access, access to employment, and transit-orientation. This opens the question as to whether New Urbanism's ideas about spatial social equity might be better achieved by fundamentally different strategies, such as grassroots urbanism. 
TABLE OF CONTENTS

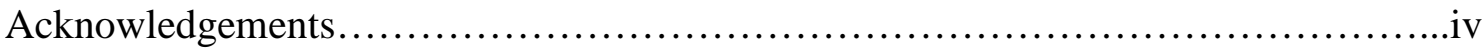

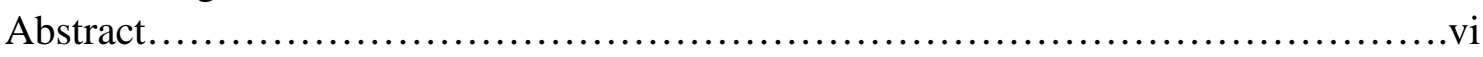

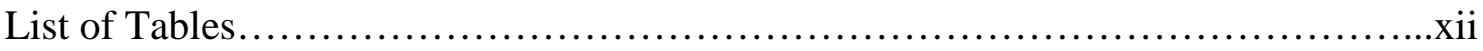

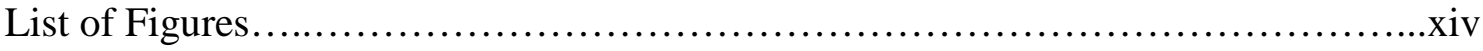

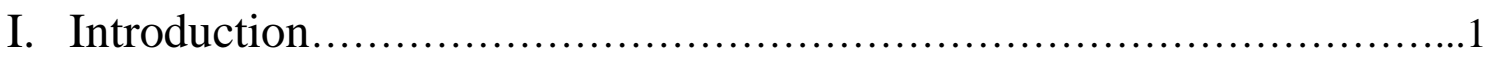

II. Background Information on Louisville, Clifton and Norton

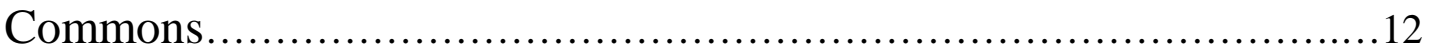

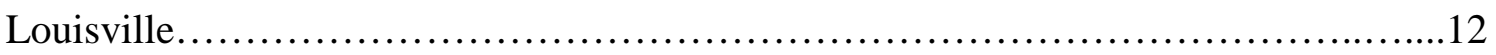

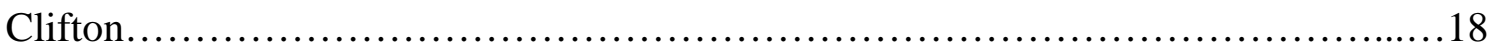

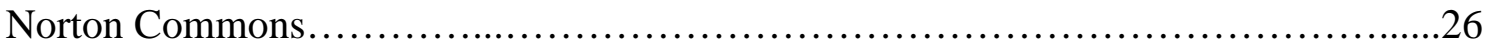

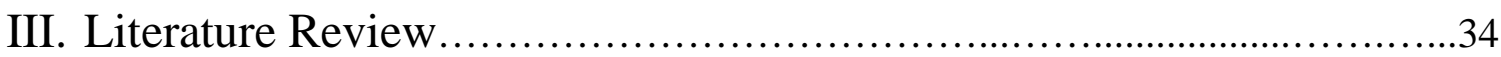

New Urbanism and Re-creating Urbanism from Scratch: What does it do for

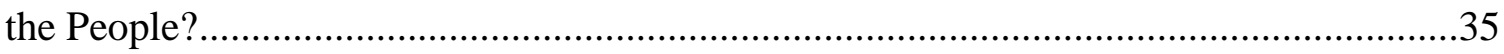

Alternatives: Fixing the City through Grassroots Efforts...............................44

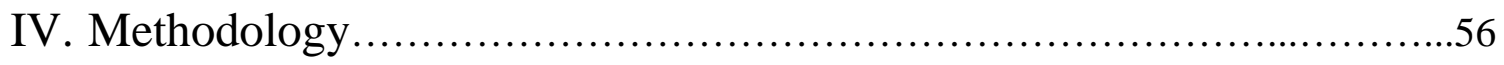

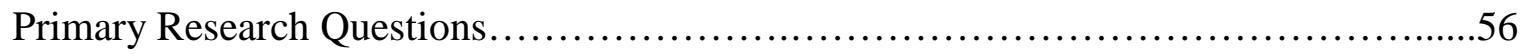

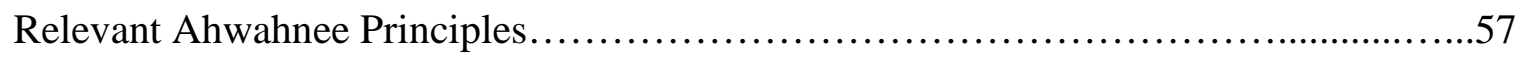

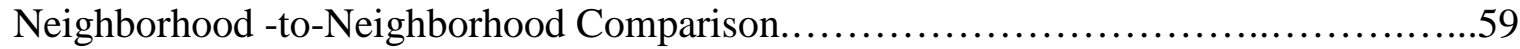

Potential Inter-neighborhood Contributions...........................................66 


\section{TABLE OF CONTENTS--CONTINUED}

Regional Comparison........................................................ 70

Data Collection/Sources..................................................... 75

Hypotheses........................................................... 77

Benefits of Research.......................................................78

Limitations of Research..........................................................

IRB Considerations....................................................... 79

V. Neighborhood Comparison of Social Equity Indicators

for Clifton and Norton Commons..........................................80

Central Importance Indicators.............................................81

High Importance Indicators............................................... 84

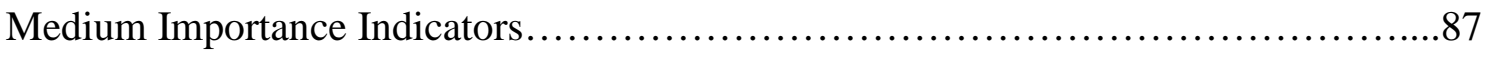

Low Importance Indicators.............................................98

Industry Types by Neighborhood.........................................101

Comprehensive Analysis of Social Equity Indicators at the Neighborhood

Level for Clifton and Norton Commons........................................107

VI. Comparison of Social Equity Indicators for the Respective

Nearby Areas of Clifton and Norton Commons.............................110

Central Importance Indicators............................................110

High Importance Indicators..............................................112

Medium Importance Indicators...........................................115 


\section{TABLE OF CONTENTS--CONTINUED}

Low Importance Indicators

Industry Types by Neighborhood

Comprehensive Analysis of Social Equity Indicators for Nearby

Areas.

VII. Regional Comparison of Social Equity Indicators for Clifton And Norton Commons and Comprehensive Overview of

Findings

Regional Transit Orientation................................................133

Potential Demographic Reach.................................................137

Comprehensive Analysis of Social Equity Indicators at the Regional Level for

Clifton and Norton Commons

Comprehensive Overview of Neighborhood, Surrounding Area, and Regional

Comparison.

VIII. Counterarguments within New Urbanism....

Counterargument Number 1: New Urbanism may not Positively Impact Social Equity, but it is Innocuous.

Counterargument Number 2: New Urbanism may not Positively Impact Social Equity, but it Positively Impacts the Environment

Counterargument Number 3: New Urbanism will Work as a Means of Revitalizing Public Housing through HUD

Counterargument Number 4: A Marriage between Private New Urbanism and the Dispersal Consensus will Aid in Creating Spatial Social Equity....

Chapter Summary 


\section{TABLE OF CONTENTS--CONTINUED}

IX. Exploring the Grassroots Alternative for

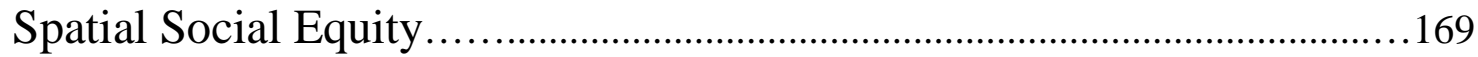

Proposed Federally-funded Urban Advocacy: An Overview.........................171

Proposed Federally-funded Urban Advocacy: Discussion...........................176

Two Types of Urban Revitalization.............................................177

Comparison to Progressive Localism...........................................178

Louisville and Neighborhood Organizations......................................180

Cost of Plan/Counterargument for Non-spatial Redistribution...........................181

Lessons from the Past: The Great Society and Community Organization..............184

How the Plan for Federally-funded Urban Advocacy will Work.......................189

Proposed Plan's Relationship with Existing Research...............................196

Concluding Thoughts on Federally-Funded Urban Advocacy..........................200

X. Conclusions.............................................................206

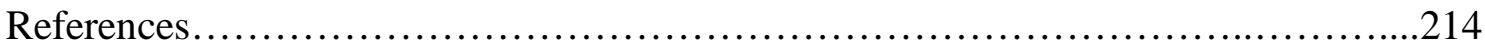

Appendix A- Primary Data Log: Specific Amenities of Clifton, Norton

Commons, and the Surrounding Areas of Each Neighborhood.........................231

Appendix B- Census Tracts within Transit Range of Clifton and Norton Commons....................................................................... 250

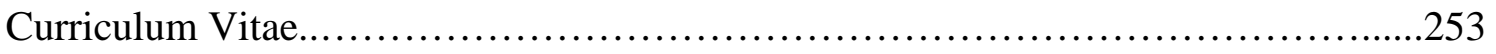




\section{LIST OF TABLES}

4.1 Ahwahnee Principles Used for Study....................................57

4.20 Central Importance Indicators (Methods)................................60

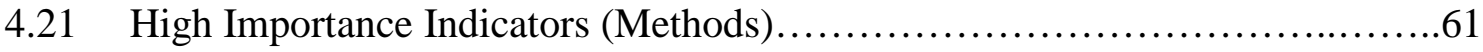

4.22 Medium Importance Indicators (Methods)...............................62

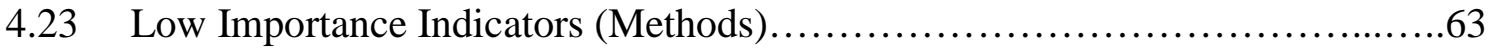

4.3 Regional Comparison (Methods)..........................................74

4.4 Primary Data Collection Tool........................................75

5.1 Results for Central Importance Indicators of Social Equity at the

Neighborhood Level................................................81

5.2 Results for High Importance Indicators of Social Equity at the

Neighborhood Level....................................................84

5.3 Results for Medium Importance Indicators of Social Equity at the

Neighborhood Level....................................................87

5.4 Results for Low Importance Indicators of Social Equity at the

Neighborhood Level......................................................98

5.50 The Six Types of Service Industries...................................... 102

5.51 Industry Types by Neighborhood: Clifton and Norton Commons..............103

5.52 Industry Types as Percentage of Neighborhood's Total Industry................104

6.1 Results for Central Importance Indicators of Social Equity for the Nearby Areas of Clifton and Norton Commons..................................110

6.2 Results for High Importance Indicators of Social Equity for the Nearby Areas of Clifton and Norton Commons..................................112

6.3 Results for Medium Importance Indicators of Social Equity for the Nearby Areas of Clifton and Norton Commons. 


\section{LIST OF TABLES--CONTINUED}

6.4 Results for Low Importance Indicators of Social Equity for the Nearby Areas of Clifton and Norton Commons....................................122

6.50 Industry Types for the Nearby Areas of Clifton and Norton Commons............124

6.51 Industry Types as a Percentage of Total Industry for the Nearby Areas of Clifton and Norton Commons................................................

7.1 Results for Social Equity Indicators Related to Regional Transit Orientation for Clifton and Norton Commons.

7.2 Households and Income Demographics of Census Tracts located within Five Miles of Clifton and Norton Commons.............................137

A.1 Clifton’s Specific Amenities............................................231

A.2 Clifton Heights' Specific Amenities......................................238

A.3 Crescent Hill’s Specific Amenities.........................................240

A.4 Norton Commons' Specific Amenities......................................242

A.5 Specific Amenities for Suburban Shopping Area South of Norton Commons.........................................................247

A.6 Wolf Trace Subdivision's Specific Amenities..............................249

B.1 Census Tract within Transit Range of Clifton...............................250

B.2 Census Tracts within Transit Range of Norton Commons......................251 


\section{LIST OF FIGURES}

2.1 Poverty Distribution in Louisville, Kentucky...............................17

2.20 Photographs of some of the many neighborhood businesses that line Clifton’s Frankfort Avenue...............................................21

2.21 Photographs of various housing types within Clifton

2.22 Street Map of Clifton...................................................22

2.3 Street Map of Clifton, with nearby portions of

Clifton Heights and Crescent Hill.......................................26

2.40 Norton Commons Town Plan.............................................28

2.50 Norton Commons’ 2016 Homearama Advertisement..........................28

2.51 Upscale Amenities in Norton Commons...................................29

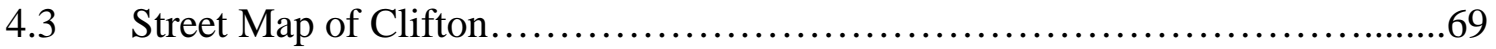

5.20 Neighborhood to Neighborhood Ratio of Select High

Importance Indicators of Social Equity...........................................85

5.30 Neighborhood to Neighborhood Ratio of Select

Housing-Oriented Medium Importance Indicators of Social Equity.............89

5.31 Neighborhood to Neighborhood Ratio of Select Employment-Oriented

Medium Importance Indicators of Social Equity....................................90

5.32 Neighborhood to Neighborhood Ratio of Select Amenity-Oriented

Medium Importance Indicators of Social Equity............................91

5.4 Neighborhood to Neighborhood Ratio of Low Importance Indicators of

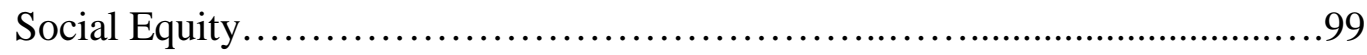

5.5 Neighborhood to Neighborhood Ratio of Various Industry Types..............104 


\section{LIST OF FIGURES--CONTINUED}

6.2 Ratio of Select High Importance Indicators of Social Equity

for the Nearby Areas of Clifton and Norton Commons.......................113

6.30 Ratio of Select Medium Importance Employment-Oriented Indicators of Social Equity for the Nearby Areas of Clifton and

Norton Commons.......................................................117

6.31 Ratio of Select Medium Importance Amenity-Oriented Indicators of Social Equity for the Nearby Areas of Clifton

and Norton Commons.................................................. 118

6.4 Ratio Automobile Lanes for the Nearby Areas of Clifton and Norton

Commons............................................................123

6.5 Ratio of Various Industry Types for the Nearby Areas of Clifton and Norton

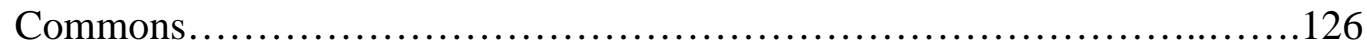

7.1 Ratio of Transit Times for Clifton and Norton Commons.......................134

7.2 Ratio for Clifton and Norton Commons of Various Indicators of Potential Regional Reach.......................................................138 


\section{CHAPTER I}

\section{INTRODUCTION}

Despite scholars claiming New Urbanism has shifted towards a focus upon the environment and community-orientation in recent years (Trudeau, 2013), promoting social equity continues to be a key component of what New Urban proponents hope to accomplish. New Urbanism’s founders have advertised New Urbanism as a response to the decline of the American dream, due to suburban sprawl (Duany, Plater-Zyberk, and Speck., 2000). Additionally, proponents of New Urbanism claim that it addresses the spatial segregation of social groups, while scholars have alluded to the Congress of New Urbanism's desire to end the separation between the rich and the poor (MacLeod, 2013).

At face value, some of the social goals of New Urbanism appear to be in line with urban scholars who for decades have lamented the general deterioration of urban environments (Jacobs, 1961), and later posited that severe social inequality results from suburban sprawl and related poverty concentration (Dreier, Mollenkopf, and Swanstrom, 2014). There has been some debate as to whether concentrated poverty has decreased thus far in the $21^{\text {st }}$ century (Jargowski, 2013). However, it is likely the case that there are simply slightly lower levels of poverty spread out over a larger number of census tracts, resulting in similar problems as those identified in the latter part of the $20^{\text {th }}$ century (Calste, 2005). Thus, the social concerns related to deteriorating urban areas that New Urbanism seeks to address appear to still be relevant. 
Many of the Ahwahnee Principles, the principles in which New Urban communities are rooted, call for an environment sensitive to these issues. The Ahwahnee Principles stipulate that neighborhoods have characteristics such as affordable housing for a mix of income groups, walkable access to facilities that address one's daily needs, and transit friendliness (Fulton, 1996).

Despite the principles and goals of New Urbanism, for the most part scholars have found a proliferation of New Urban communities that lack the aforementioned social necessities. Perhaps this state of New Urbanism is due to the very expansive and unclear definition of New Urbanism that has been attributed to the movement by planning staffers (Jepson, Jr. and Edwards, 2000). Whatever the case, scholars have found New Urban developments to be typically located on the suburban fringe, and largely unaffordable to even middle-income residents (Eppli and Tu, 1999 and 2014). Certainly, there is evidence of the diversification of suburban America, with nearly half of the increase in poverty between 2000 and 2008 occurring in suburbs (Garr and Kneebone, 2010). However, the prototypical New Urban community could best be described as suburban and affluent (Talen, 2010), in sharp conflict with the concerns about exclusion and sprawl expressed within the movement.

It is worth noting that there is a sizable contingency of New Urban communities that are located in poor urban areas, often in an attempt to create more dignified public housing units (Ellis, 2002). These neighborhoods were mostly built under the United States Department of Housing and Urban Development's (HUD) Hope VI program, beginning in 1992 (Levy, 2004), until it was replaced by a similar program, Choice Neighborhoods, in 2013 (Couch, 2015). However, by all indications, private, affluent, 
suburban New Urban communities still represent perhaps three-quarters of New Urban communities (Leinberger, 2007). Thus, they appropriately remain a focal point when studying New Urbanism. Certainly, there are potential issues to be evaluated regarding this portion of New Urban communities produced through Hope VI and Choice Neighborhoods. However, evaluating these concerns requires a substantially different focus beyond the scope of this study.

Issues regarding the affordability and location of New Urban communities speak to a larger question about the degree to which New Urbanism can potentially contribute to social equity. As planning frequently looks at things in terms of sustainability, equity is certainly a paramount concern. Within the "Three E's" of sustainability, regarding economic, social, and environmental sustainability (World Commission on Environment and Development, 1987), the "E” for social sustainability refers to equity. Scholarship has identified certain neighborhood characteristics that contribute to social equity and social sustainability, including fair distribution of income, employment opportunities, and general accessibility (Dempsey, Bramley, Power, and Brown, 2008). Though social sustainability has a myriad of definitions, another way in which it has been defined is the existence of provisions facilitating daily life operations within a neighborhood or area (Chan and Lee, 2008). In congress with housing affordable to all within a neighborhood and resident access to the remainder of the metropolitan area, it could be argued that provisions for daily operations provide the final link for what is necessary for social equity to exist, spatially.

In examining the degree to which New Urbanism does, or does not, potentially contribute to social equity, it is necessary to choose a community to serve as the 
prototypical private New Urban community. The New Urban community selected for this purpose is Norton Commons, in Louisville, Kentucky. Norton Commons is a New Urban community typically referred to as upscale (Norton Commons LLC, 2016), located 13 miles east of downtown, in the affluent community of Prospect.

It is useful to have a point of comparison when evaluating this New Urban community, to provide context. For these purposes, this study will focus upon Clifton, an urban neighborhood located two miles east of downtown Louisville, with a recent reputation of revitalization (Garr, 2017), potentially addressing the aforementioned hallmarks for spatial social equity: affordability, neighborhood access to provisions for daily goods, and regional access. As New Urbanism aspires to recreate many of the things lost by urban decimation, it makes sense to compare Norton Commons to a neighborhood that is urban in the traditional sense, which has done a relatively good job of staving off decline.

As it is in the same county, Clifton may represent an achievable model for Louisville and Jefferson County to replicate in creating spatial social equity. Comparing a New Urban neighborhood in Louisville to a vibrant urban neighborhood in Manhattan, for example, would serve very little point.

With the active Clifton Community Council, the grassroots presence of Clifton also makes it an interesting choice for this comparison. Grassroots efforts, in a variety of forms, are direct, on-the-ground involvement with the urban environment, and have great capacity for replication. Many such efforts, through dogged activism, are able to set the tone for their own neighborhood agenda, rather than being dependent upon substandard, top-down agendas (Sirianni and Friedland, 2001). Proponents argue that grassroots 
community development leads to social partnership and asset-building (Gindin, 2002), strategies more likely to uplift communities as a whole (Imbroscio, 2016). Some argue that grassroots efforts to combat competing regional government interests allow for collective and community-based remedies to be pursued (Self, 2003).

There is some scholarship that suggests similarities between New Urbanism and grassroots urbanism. Pyatok (2000) compares the work of New Urbanists to grassroots progressive planners and academics of the 1960s, who worked to shape the communities of the underclass. It is the argument of this dissertation, however, that these two paradigms are dramatically opposed in nature. New Urbanism is top-down in nature, and thus highly removed from the on-the-ground aspects of grassroots revitalization.

The results of this study suggest that New Urbanism may not be a viable strategy for generating social equity, so alternative pursuits must be explored. As such, my dissertation will explore grassroots efforts as an alternative, due to the direct involvement with urban areas of such movements, as well as their capacity to be replicated. It is, however, beyond the scope of this study to establish a direct link between the grassroots presence of Clifton and whatever potential the neighborhood has the potential to contribute to social equity. While Clifton is a fitting choice for this study, all that can be empirically stated about Clifton is that the results demonstrate certain characteristics that relate to the potential contribution to social equity of a viable urban neighborhood in Louisville. Additionally, it must be noted that the demographics of Clifton are not necessarily minority-oriented in nature, as is often the case with grassroots movements discussed in literature (DeFillipis, Fisher, and Schragge, 2010). Nonetheless, it is likely 
the case that many practices and conditions that take place within Clifton may be relevant to urban regeneration on the whole.

This dissertation evaluates the potential contribution to social equity of two neighborhoods, with four structural considerations embedded within the study:

1) What economic groups are able to live in the neighborhood?

2) What provisions for daily life operations exist in the neighborhood?

3) How many people, and what types of economic groups, within the region are able to access the neighborhood without an automobile?

4) How has the neighborhood positioned itself, regionally, for neighborhood residents to benefit from opportunities throughout the rest of the region?

For the purposes of this study, any potential contributions to social equity are being evaluated in terms of how they can be made spatially, or through the built environment. There are three levels of space are evaluated in an attempt to address these considerations:

1)The neighborhood level, 2)The inter-neighborhood level, 3)The regional level.

The aforementioned structural considerations demonstrate why this study is evaluating these contributions to social equity at the neighborhood and regional level. In terms of evaluating social equity contributions at the inter-neighborhood level, such an evaluation is based upon the consideration that certain aspects of neighborhood boundaries are arbitrary (Peterman, 2000). Thus, nearby areas to a neighborhood may be able to function as if they are part of the same neighborhood, in many ways. The dichotomy of urban neighborhoods and New Urban neighborhoods in this regard makes the inter-neighborhood portion a worthwhile addition to the study. New Urban communities have adopted a principle of clear neighborhood delineation, which has been 
criticized by scholars (Talen, 1999), and also are typically surrounded by areas that may not be urban in nature (Garde, 2004). This lack of inter-connection potentially impact who, across neighborhood boundaries, might be able to access a neighborhood in a fashion similar to those actually living in the neighborhood. Additionally, lack of focus upon nearby areas can potentially impact the degree to which residents of the neighborhood in question might have access to additional provisions for daily life operations. The nearby area in question could range from a bustling urban neighborhood to vacant farmland, so the contribution of employment and consumer goods by a nearby area can vary greatly.

Due to the scale involved in this study, neighborhood and inter-neighborhood contributions to social equity can be evaluated quite thoroughly. The Ahwahnee Principles upon which New Urbanism is based have ten principles that, to varying degrees, address social equity through consideration for all income groups and provisions for daily life operations. The remaining five Ahwahnee principles are largely environmental principles, advocating for things such as design for solar use (Fulton, 1996). While these environmental principles may serve a valuable purpose, they are beyond the scope of this study. In looking at the ten relevant Ahwahnee principles, considerations such as a mix of housing prices, jobs for a variety of economic groups, neighborhood-based consumer goods, civic facilities, green space, walk-ability, and transit access are the primary focal points (Fulton, 1996). Thus, there are enough commonalities between the Ahwahnee Principles and social equity considerations, such as access for all income groups and provisions for daily life operations, for these principles to serve as an effective measure for spatial contributions to social equity. 
Additionally, given the close ties between the Ahwahnee Principles and New Urbanism, there is not only a relationship between these principles and social equity, but also an acknowledgement that New Urbanism seeks to achieve what is outlined by the principles. So, while a strong argument can be made that principles behind New Urbanism have social equity in mind, the ultimate question is whether or not New Urbanism actually reflects these principles.

By incorporating an urban neighborhood such as Clifton into the comparison, consideration is being given into whether New Urbanism's goals may be more achievable in an older, traditional urban environment, which has been maintained by methods other than New Urban design. With this in mind, this study will use the Ahwahnee Principles as a guideline for comparison of contributions to social equity for both Norton Commons and Clifton at the neighborhood level, as well as at the inter-neighborhood level (as this level of space can also be judged in this fashion). Regional Ahwahnee Principles do not heavily focus upon provisions that potentially provide social equity (Fulton, 1996), so to evaluate social equity considerations at the regional level, it is best to develop an independent measure. Evaluation of the spatial orientation to social equity of Norton Commons and Clifton at this level will relate to the ability of each neighborhood to be reached through public transit from poor downtown areas; how many people, and from what economic groups, may be able to easily reach each respective neighborhood without an automobile; and the degree to which these neighborhoods have public transit access to employment opportunity throughout the region. Detailed description of exactly how these neighborhoods were evaluated according to these standards will be provided in the methodology chapter (Chapter IV). 
Low-income residents may be more reliant upon using their neighborhood as a center for activity than higher income residents, who may use the entire city to meet their needs (Peterman, 2000). For this reason, throughout this study, primacy will be given to characteristics that potentially contribute to the needs of lower income residents. In the methodology chapter, the social equity proxies derived from the Ahwahnee Principles will be given a hierarchy on this basis as well.

It is worth briefly noting, considering this study's focus upon social equity, what portion of the concept of social equity, as a whole, this study is examining. There are components of spatial social equity that are not accounted for by this study (discussed below). Additionally, social equity in a non-spatial sense is entirely beyond the scope of this dissertation. In addition to issues of access, there are a myriad of potential problems that scholars suggest occur due to a lack of income mixing, which cannot be captured by this study. There are many assertions within urban studies that concentrated poverty heavily contributes to an undesirable social environment for an area's residents. In theory, such concentrations, as associated with problems like dysfunctional schools, the prevalence of crime, mass incarceration, and other issues (Wilson, 1987 and 1996; Wacquant, 2002). To acknowledge the prevalence of this argument, the New Urban Ahwahnee Principles do broadly describe the need for income mixing (Fulton, 1996). However, the primary focus of New Urbanism, and this study, is the use of space.

These issues regarding concentrated poverty remain a necessary focus for urban regeneration paradigms such as New Urbanism and grassroots neighborhood revitalization. Though much of the scholarship regarding poverty concentration began in the 1980s and 1990s (Wilson 1987 and 1996; Jargowski, 1997), there are indications that 
the problem has remained strong through the first decade of the $20^{\text {th }}$ century. Jargowski (2013) notes that mid-sized cities saw a 2.8 percent increase in high-poverty neighborhoods between 2000 and 2010. This increase disproportionately affected African-Americans, with a 4.4 percent increase in predominantly-black, high-poverty neighborhoods between 2000 and 2010 (Jargowski, 2013). Additionally, Jargowski (2013) argues that high-poverty neighborhoods are more spread out within the metropolitan area than in 2000, making it even more difficult for the poor to access redistributive services.

Beyond social equity being a spatial issue, it is also a matter that comes under considerable scrutiny, in a non-spatial sense, as it relates to the political economy. Scholars point to issues such as increasing income disparity, corporate control, and the reduction of social programs, as neoliberal developments that have wrought havoc over American social equity in recent decades (Katz, 1996; Alperovitz, 2004; and Kenworthy, 2014). As the elements of this study are largely approaching social equity in a placebased fashion, as opposed to looking at broader issues of the political economy, this in some ways could be viewed as a "place matters" study. "Place matters" is a reference to the book written by Peter Dreier, John Mollenkopf, and Todd Swanstrom (2014) that thoroughly argues that urban sprawl and concentrated poverty have resulted in the destruction of opportunity for lower-income individuals. It must be acknowledged that a compelling argument could be made that the effects of the political economy upon social equity are even stronger than place-related effects (Sclar, 2002). However, this study simply assumes that there is some meaningful impact that place-based problems have upon social equity. As long as social sustainability and social equity remain a component 
of urban planning and urban studies, urban scholars must assume that social equity is at least in part a spatial issue. Otherwise the conversation regarding social equity would simply be left to other social scientists outside of urban studies.

The central contribution to the literature offered by this study is that it expands upon the debate regarding the affordability of New Urbanism (Talen, 2010; Trudeau and Kaplan, 2015), delving into the overall impact of New Urban communities upon accessbased social equity.

Ultimately, the primary objective is for this study to serve as a microcosm that can address the following broader question: How do New Urban communities compare to viable, existing urban areas in terms of spatial provisions that can potentially contribute to social equity? In building towards this question, Chapter II presents a more in-depth picture of Clifton, Norton Commons, and Louisville as a whole. Chapter III presents a literature review of New Urbanism, grassroots neighborhood revitalization, and the relationship with social equity of each paradigm. Chapter IV presents this study's methods for exploring social equity within these neighborhoods. Chapters V-VII present the related findings for social equity indicators for the neighborhood, nearby area, and regional comparisons between Clifton and Norton Commons. Chapter VIII examines the counterarguments within New Urbanism that could result in light of the hypotheses of this study (to be introduced in Chapter IV) being correct. Chapter IX details the exploration of a grassroots alternative to the potential shortcomings of New Urbanism. Finally, Chapter X provides conclusions (regarding the ineffectiveness of New Urbanism at providing spatial social equity and the need for a grassroots alternative), tying the dissertation together. 


\section{CHAPTER II}

\section{BACKGROUND INFORMATION ON LOUISVILE, CLIFTON, AND NORTON COMMONS}

In order to provide more context for the comparison between Clifton and Norton Commons, as well as their interaction with the Louisville region, it is helpful to have background information about both neighborhoods and the city itself. This chapter is broken down into sections about Louisville, Clifton, and Norton Commons.

\section{Louisville}

To provide a brief picture of Louisville in a national context, it is a mid-sized city, which is primarily known as the site of the Kentucky Derby. Louisville is situated on the Ohio River and shares elements of both Midwestern and Southern culture. Major employers and industries include UPS, General Electric, Ford, Yum! Brands (this company is comprised of several fast food chains), Papa John's, several healthcare and health insurance companies, and the Catholic Church ${ }^{1}$. As it relates specifically to the issues of this study, there are many elements of Louisville that may be similar to other cities across the country, among them its population as a whole, urban sprawl, and poverty concentration. Thus, Louisville will be frequently used as a point of reference

\footnotetext{
${ }^{1}$ Derived from “Top 20 Private Sector Companies" at GreaterLouisville.com.
} 
throughout this dissertation in addressing issues of spatial social equity raised by the study.

As a consolidated city-county, the population of Louisville is just under 600,000 residents (United States Census Bureau, 2010), placing Louisville as the $30^{\text {th }}$ largest city in the country. This figure is somewhat misleading, under the complexities of Louisville's city-county consolidation. For one, there have been attempts to count incorporated cities in the population total, which would raise the population total to over 740,000 residents (United States Census Bureau, 2010). Additionally, the 2003 consolidation drastically altered the amount of land that is actually considered part of the “city”, cosmetically creating an almost threefold increase in the population count from the pre-merger population of just under 260,000 residents (United States Census Bureau, 2000). Current population counts, after the 2003 consolidation, mostly amount to simply taking many of the county's suburbs and then shifting their population totals into the population total for the central city. As there have been only four major city-county consolidations in the past hundred years (Savitch and Vogel, 2004), using Louisville’s official city population count as a basis for comparison to other cities is somewhat misleading. Looking at the city’s pre-merger population, or comparing its metropolitan area population of just under 1.3 million residents to other metropolitan areas (United States Census Bureau, 2010), probably provides the most substantive picture as to the size of Louisville as an American city. In terms of metropolitan area ranking, Louisville places $43^{\text {rd }}$ nationally (United States Census Bureau, 2010). While many of the counties comprising Louisville’s metropolitan area are of low density, comparing metropolitan 
areas is at least a uniform means of comparing cities, as opposed to comparing citycounties to pure cities.

Demographically, the racial breakdown of Louisville is $75 \%$ white, $22 \%$ AfricanAmerican, and 3\% other ethnicities (United States Census Bureau, 2010). However, this racial breakdown is likely altered by suburbs being consolidated into the city; the premerger Louisville racial breakdown was 60\% White, 35\% African-American, and 5\% other ethnicities (United States Census Bureau, 2000).

Despite a relatively high population ranking of $43^{\text {rd }}$ among 382 United States metropolitan areas, by other metrics Louisville could be considered to represent the average American city in terms of population. Approximately 64 percent of Americans in metropolitan areas live in a metropolitan area larger than Louisville, while conversely Louisville has nearly twice the population of the average United States metropolitan area (United States Census Bureau, 2010). Considering that depending upon the metric, Louisville could either be classified as somewhat large, or somewhat small, perhaps it is appropriate to conclude it lies somewhere in the middle in terms of size. In terms of economic vitality, Louisville may be considered somewhat below average. Louisville ranks $48^{\text {th }}$ nationally in terms of GMP (United States Census Bureau, 2010). Additionally, the median household income is just over 39,000 dollars, only threequarters of the median household income nationally (United States Census Bureau, 2010). Thus, Louisville could be considered slightly below average in economic performance, in this regard. However, as it relates to this study, the biggest reason why Louisville can be classified as a mid-sized, average American city, is because it is the appropriate population size to feel the destructive forces of urban decline which 
especially plague the mid-sized American city. It is not so small that only a minimal urban population and infrastructure was damaged by urban decline and sprawl in the latter half of the twentieth century (Ewing and Hamidi, 2014). Nor is it so large and prominent, on the national level, to experience the urban vitality of many top-ten, global American cities, which function as centers of innovation, such as New York; Chicago; Washington, D.C.; San Francisco; Boston; and other prominent American cities (Florida, 2002; VonHoffman, 2004; and Sassen, 2006). As a mid-sized American city which aligns with conditions typically associated with issues of urban decline and urban sprawl, Louisville is an appropriate choice for evaluating strategies which hope to reverse the effects of such urban phenomena. In the case of this study, such strategies are present in New Urbanism and grassroots neighborhood revitalization.

As it relates to the issues of urban decline and urban sprawl, metrics suggest that Louisville strongly possesses elements of both. In comparing available statistics, Louisville's population declined from approximately 360,000 residents in 1970 (United States Census Bureau, 1970) to approximately 270,000 for the pre-merger 2000 census (United States Census Bureau, 2000). During the same period of time, Louisville’s urban area population grew from approximately 740,000 in 1970 (United States Census Bureau, 1970) to approximately 970,000 in 2000 (United States Census Bureau, 2000). When defining the city population as "urban" and the remaining urban area population as “suburban”, Louisville went from suburban residents accounting for 51 percent of the urban area population in 1970 to 72 percent of the urban area population in 2000. Additionally, within the urban area, the suburbs went from outnumbering the urban population by 20,000 residents in 1970 to outnumbering the urban population by 430,000 
residents in the 2000. It is certainly suggestive of urban sprawl for such a swing to occur during the final three decades of the twentieth century.

In addition to urban sprawl, perhaps to an even greater extent, metrics suggest that Louisville strongly feels the effects of urban decline. One of the most prominent signs of urban decline, which is often a focal point for urban scholars, is concentrated poverty (Pendall, Theodos, and Hildner; 2014). Over 80 percent of Louisville’s census tracts with over 25 percent of the population in poverty (a poverty level double the rate for the city as a whole; see United States Census Bureau, 2010), are part of a contiguous sea of thirty-plus impoverished census tracts, located immediately west of downtown Louisville. The scope of concentrated poverty areas in Louisville is exceptionally high, as in 2000 Louisville ranked third nationally in terms of proportion of census tracts with concentrated poverty, behind Fresno and New Orleans (Berube and Katz, 2005). The reference to census data from 2000, rather than 2010, is necessary due to Louisville’s 2003 consolidation with Jefferson County. Incorporating suburbs into the city makes it difficult to establish a post-merger ranking regarding concentrated poverty. However, there has been no evidence that Louisville's concentrated poverty problem has undergone meaningful change since 2000 (Louisville Metro Government, 2015). Certainly, Louisville is emblematic of the decimated urban core struggling with concentrated urban poverty which inspires such efforts as New Urbanism and grassroots neighborhood revitalization.

Figure 2.1 displays the concentrated poverty distribution in Louisville. On this map, it is worth noting that over half of the Louisville census tracts with extremely low poverty levels (below 5 percent) are located in the contiguous tracts in the northeastern 
corner of Louisville, as well as along the eastern edge. This pattern is demonstrative of the distribution of suburban affluence within Louisville, particularly throughout these areas. It is also worth noting that Norton Commons is located in this affluent northeastern corner of the city-county.

Figure 2.1: Poverty Distribution in Louisville, Kentucky. (Source: American Community Survey, United States Census Bureau, 2006-2010)

NEIGHBORHOOD POVERTY IN LOUISVILLE Percentage of People Whose Income in the Past 12 Months is below the Poverty Level, by Census Tract, 2006-2010

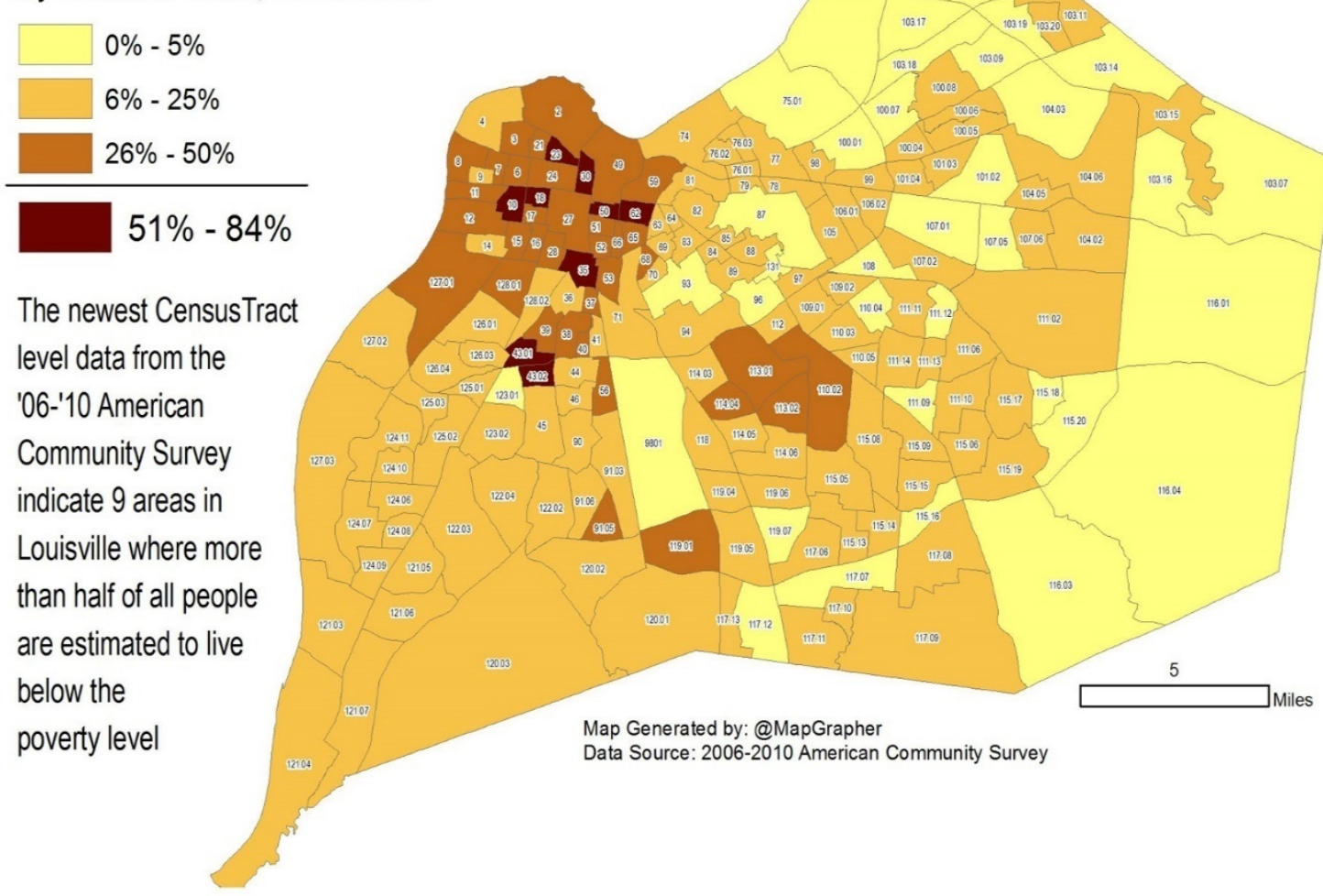

With rather typical issues surrounding urban sprawl, and severe issues regarding concentrated poverty and urban decline, Louisville exemplifies the problems that urban strategies such as New Urbanism and grassroots revitalization hope to address. It was 
argued in Chapter I that New Urbanism envisions itself to be a remedy for the decline of the American dream due to urban sprawl, as well as the end of the separation between the rich and poor. Thus, Louisville offers ideal circumstances for the capacity of New Urbanism to be tested. Such urban conditions allow alternative strategies for revival of the urban environment, such as grassroots revitalization, to be observed as well.

\section{Clifton}

As an urban neighborhood that has experienced revitalization over the past two decades, spurred by the highly active Clifton Community Council, Clifton serves as an appropriate choice to represent a renewed urban area, revived through grassroots efforts. In contributing to spatial social equity, revitalization efforts such as those in Clifton potentially have an advantage over prototypical New Urban neighborhoods like Norton Commons, through relationship with the marketplace, design, and location. These potential advantages will be reflected in the hypotheses presented in Chapter IV, the "Methodology" chapter of this dissertation.

Clifton is located two miles east of downtown Louisville, with close to 2,500 residents (National Park Service, 2010). Its boundaries are Brownsboro Road to the north, Ewing Drive to the east, I-64 to the south, and Mellwood Avenue to the west. The racial composition for Clifton is $87 \%$ white, $8 \%$ African-American, and 5\% other ethnicities (National Park Service, 2010). The largely white composition of Clifton is quite different than the black neighborhoods which typify the grassroots revitalization efforts to be discussed in this study's literature review. However, this study primarily deals with issues such as affordability and access, as opposed to the sociology of race. As such, there are important observations to be made regarding the characteristics of a 
viable urban neighborhood, such as Clifton, regardless of racial composition. Clifton’s median household income of $\$ 40,044$ is barely higher than the median income for Louisville as a whole (National Park Service, 2010). The neighborhood's rate of collegeeducated adults, at 32 percent (National Park Service, 2010) is higher than Louisville as a whole, at 21 percent (United States Census Bureau, 2010).

In prior coursework, spending several months attending Clifton Community Council meetings produced an understanding of the evolution of the neighborhood. Prior to the beginning of revitalization efforts in the 1990s, according to long-time residents and council members, Clifton was a white working-class neighborhood. Council members referred to achieving preservation district status in 2003, as well as the active involvement of the council in neighborhood affairs, as the catalyzing forces behind the neighborhood's revitalization. In describing its revitalization, council members describe Clifton as an up-and-coming neighborhood, bustling with vibrant shops and eateries.

The council believes that through achieving preservation district status, it was able to control the character of the neighborhood. This preservation, in turn, allowed the neighborhood to thrive by remaining appealing to business owners and residents. Additionally, the presence of the council has promoted general neighborhood engagement, and a close relationship between the neighborhood and its city council representative. The council and Clifton have created makeshift parks, encouraged frequent neighborhood festivals, promoted a trade relationship between local restaurants and the community garden, and worked hard to create safe conditions for the many blind residents that live in the neighborhood. The Clifton Community Council's meeting minutes for 2013-2014 further demonstrate the council’s passion for political 
involvement, documenting the organization's fundraising to host debates for local government officials (Clifton Community Council, 2014). It is worth noting that local political involvement has a high correlation with reinforcing neighborhood advocacy (Hays and Kogl, 2007). It may not seem intuitively apparent how all of the aforementioned events could potentially result in things such as access and incomemixing, which are being evaluated by this study. However, it is frequently the case that creating an atmosphere of activism and cultural vibrancy attracts an influx of residents to boost revitalization efforts (VonHoffman, 2004). Such a revitalization ultimately serves to enhance the small business presence of a neighborhood (which impacts access on multiple levels, which will be discussed further in the "Methodology" chapter) and potentially diversifies its income distribution.

, Figure 2.20 shows photographs of the frequent distribution of business establishments within walking distance within Clifton’s existing infrastructure. Figure 2.21 displays some of the mix of housing which exists within Clifton, potentially demonstrative of mixed-income within the neighborhood. Finally, Figure 2.22 provides a street map of Clifton, delineating the boundaries by which Clifton will be measured within this study. 
Figure 2.20- Photographs of some of the many neighborhood businesses that line Clifton’s Frankfort Avenue. (Retrieved October 25, 2016, from bing.com/images)
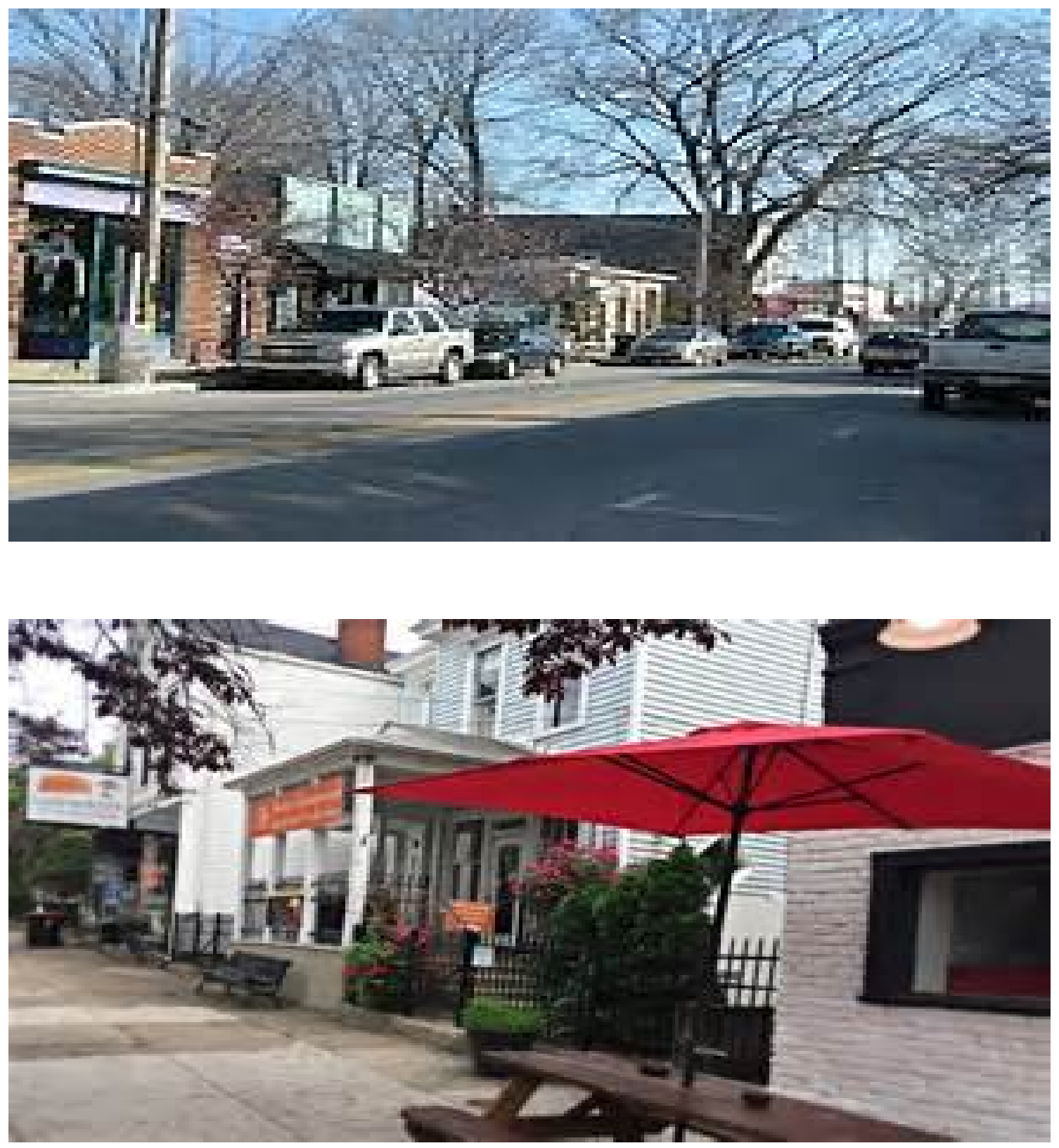
Figure 2.21- Photographs of various housing types within Clifton. (Retrieved October 25, 2016, from bing.com/images)

This Page: Large Victorian home, perhaps requiring above average income (though it could also be divided into apartments).

Next Page Top: Modest duplexes.

Next Page Bottom : Amp apartment complex, constructed in Clifton in 2015.

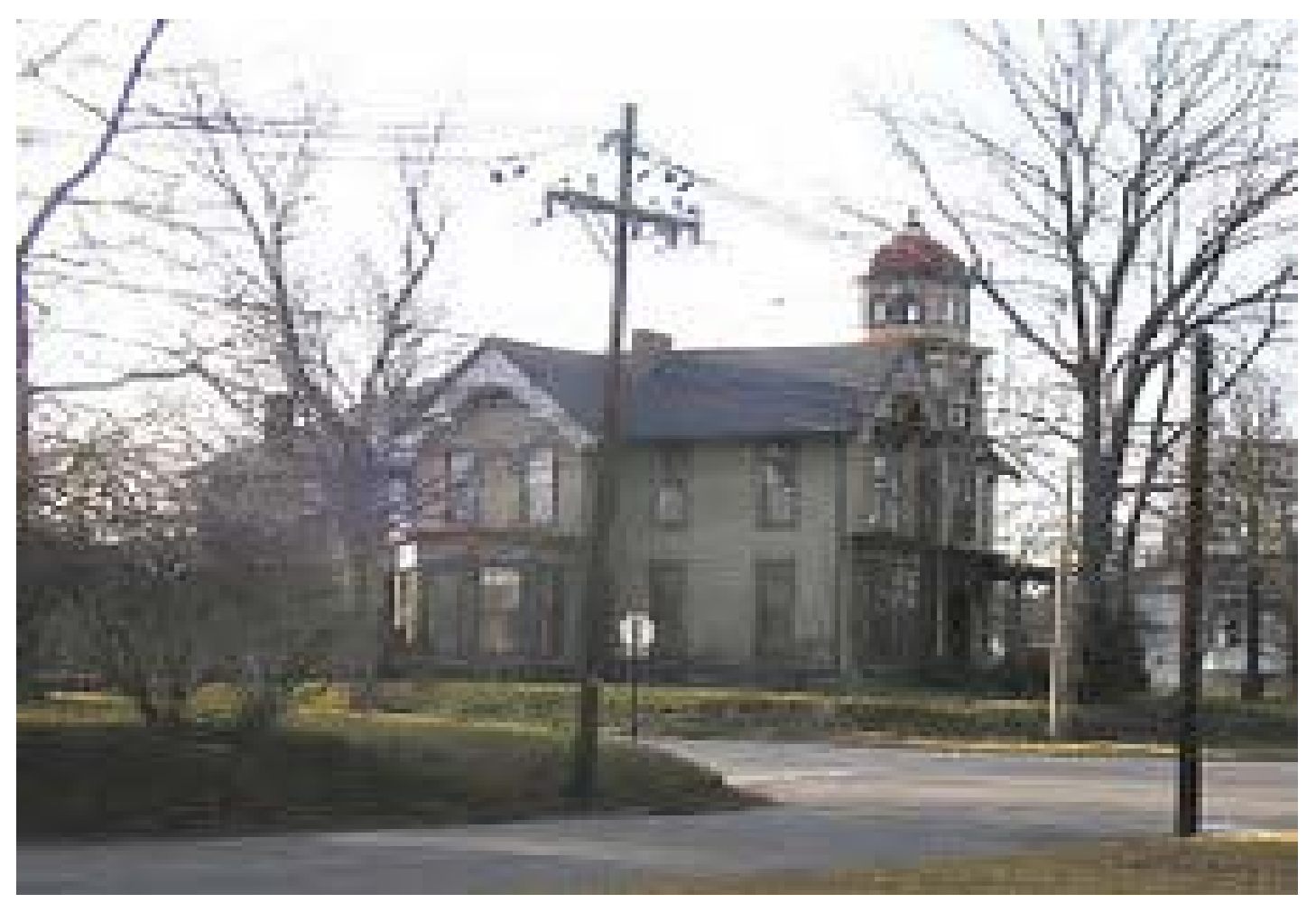



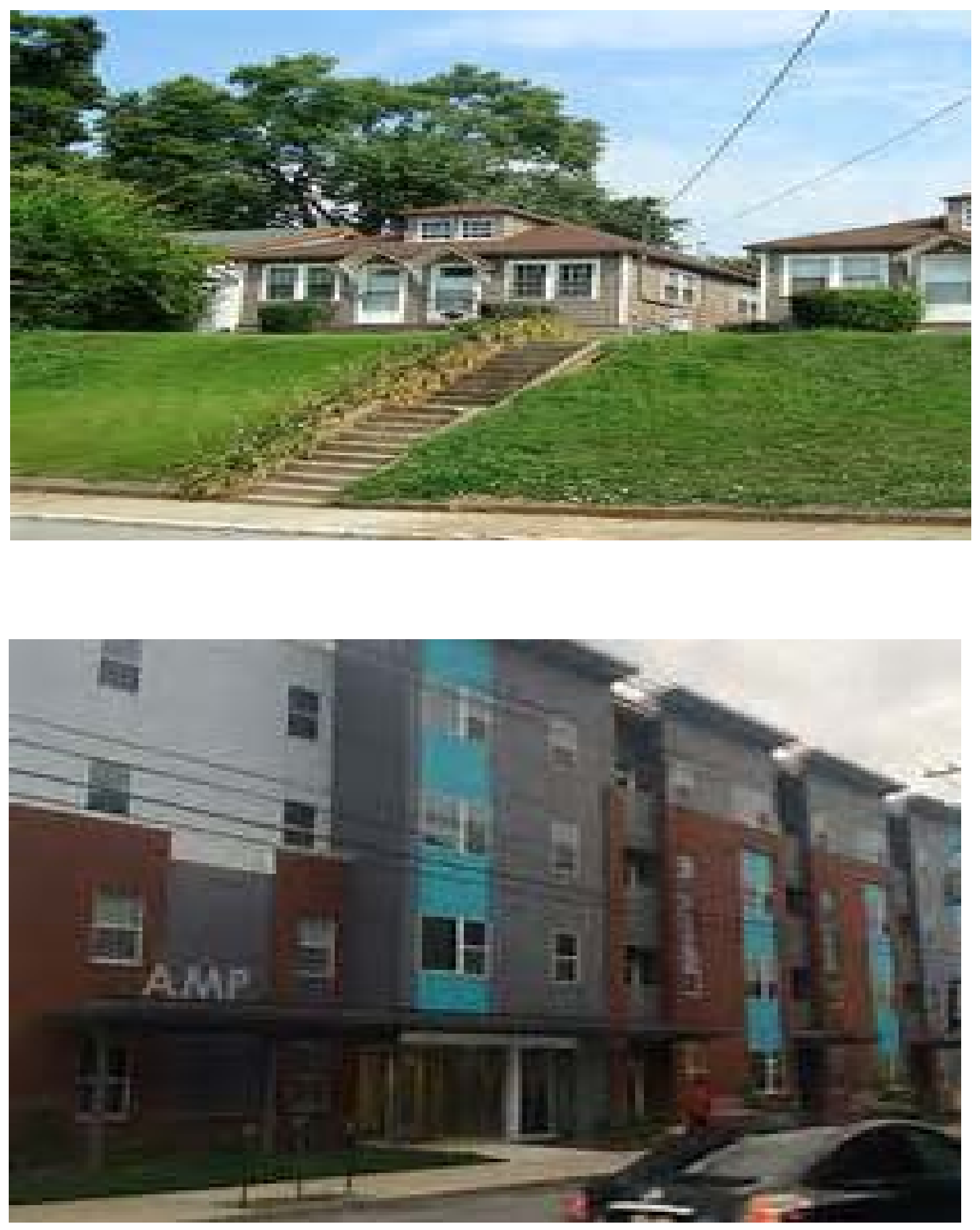
Figure 2.22- Street map of Clifton. Boundaries of Brownsboro Road to the north, Ewing Avenue to the east, I-64 to the south, and Melwood Avenue to the west. (Retrieved October 26, 2016, from bing.com/images, "Map of Louisville”)

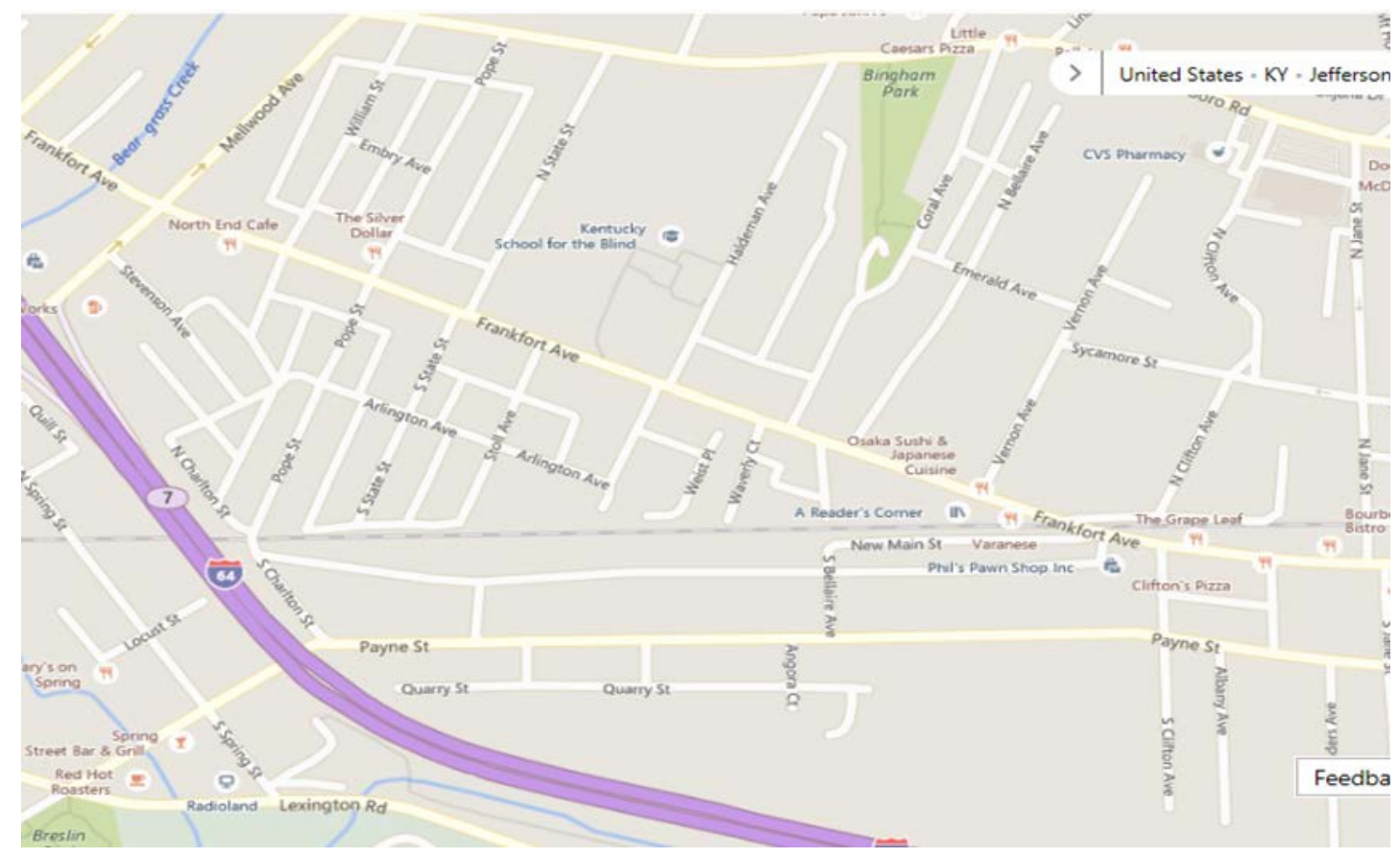

My work with the Clifton Community Council demonstrated the degree to which Clifton is, in some ways, a shared community with its nearby neighborhoods (particularly regarding Clifton Heights to the north and Crescent Hill to the east). The community council worked with the Louisville Metro Council in efforts to improve safety in crossing Brownsboro Road, as residents of the area traverse from Clifton Heights to Clifton, or vice versa. Additionally, the community council discussed the degree to which Clifton Heights residents were often employed at the businesses that exist on the Clifton side of Brownsboro Road. To some degree, designating a business as being part of one neighborhood on one side of a street, as opposed to being part of a different neighborhood on the other side of the street, may seem arbitrary. Fundamentally, 
however, this inter-neighborhood employment is indicative of how within urban areas the effects of development or revitalization can easily extend beyond arbitrary neighborhood boundaries (Peterman, 2000). As it concerns Crescent Hill, the Clifton community council frequently sells crops from its community garden to Crescent Hill restaurants. Additionally, the community council describes festivals along Frankfort Avenue, which passes through both Clifton and Crescent Hill as shared events between the two neighborhoods. Also, Crescent Hill uses the Clifton community newspaper, The Clifton Quarterly (developed by the Clifton Community Council), to advertise events, its summer camp, and real estate ${ }^{2}$.

Figure 2.3 shows a map of Clifton, along with the portions of Clifton Heights and Crescent Hill that will be evaluated within the inter-neighborhood portion of the study (to be discussed further in the "Methodology" chapter). The additional area extends 1/6 of a mile northward and eastward of Clifton's neighborhood boundaries, in an effort to represent an additional five minutes worth of walking distance within the area. Of interest to this study are the areas to the south of Edith Road and west of Mt. Holly Avenue in Clifton Heights, as well as the areas to the east of Hite Avenue and south of Brownsboro Road in Crescent Hill.

\footnotetext{
${ }^{2}$ Obtained from Clifton Quarterly, 2016 Summer edition, community newsletter created by Clifton Community Council.
} 
Figure 2.3- Street Map of Clifton, with nearby portions of Clifton Heights, to the north, and Crescent Hill, to the east. (Retrieved October 26, 2016, from bing.com/images, "Map of Louisville")

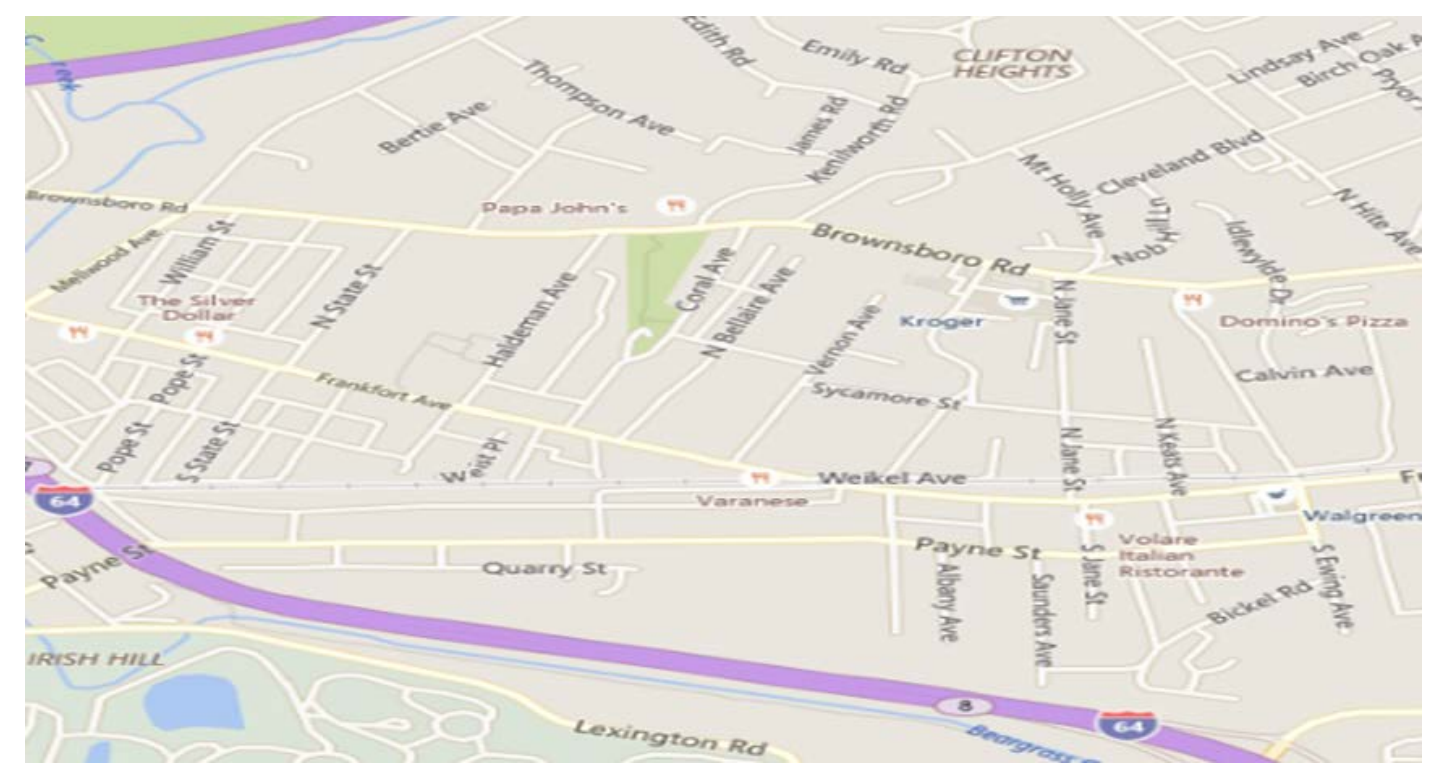

\section{Norton Commons}

Norton Commons is a private New Urban neighborhood located in the affluent suburban community of Prospect, 13 miles away from downtown Louisville, in northeastern Jefferson County. While Norton Commons is not yet old enough to have block level data available regarding the neighborhood's income distribution, it is reasonable to define it as an affluent neighborhood. Prospect, as a whole, has the third highest median household income of any community in Kentucky, at \$111,170 (United States Census Bureau, 2010), and Norton Commons refers to itself as “upscale” (Norton Commons LLC, 2016). Ultimately, Norton Commons is representative of the prototypical New Urban community, given its suburban fringe location and level of affluence (Talen, 2010). 
Norton Commons opened in 2004, on land previously known as the WAVE farm. This farm was initially owned by George Norton, founder of the local WAVE news channel and member of the prominent Norton family of Louisville (Norton Commons LLC, 2016). George Norton’s heirs, in honoring his progressive nature, hired New Urbanism founder, Andres Duany, to create a place where the rich and poor can go to work, school, and shop, within the same neighborhood (Norton Commons LLC, 2016). Some potential challenges for Norton Commons in supporting spatial social equity might relate to the conflicting narratives of being an "upscale neighborhood" and a neighborhood designed for the rich and poor. Ultimately, the neighborhood's development moved forward with the approval and feedback of regional leaders, such as the local government, planning officials, business leaders, and the media (Norton Commons LLC, 2016).

Below, Figure 2.4 displays the neighborhood or "town” plan for Norton Commons. There is a focus upon green space in the center which is reminiscent of Ebenezer Howard's utopian Garden City Model. Howard's model advocated for green space in the center of a community, in order to increase equal access for residents to said space (Howard, 1902). Figure 2.50 presents a poster for the annual "Homearama" event in Louisville, with Norton Commons being showcased in 2016. This event is often a celebration of top-of-the-line or cutting edge homes, so the inclusion of Norton Commons provides some indication of the degree to which the neighborhood is seen as "upscale" throughout Jefferson County. Additionally, Figure 2.51 demonstrates some of the upscale amenities within Norton Commons, including intricate, mansion-style housing, and an idyllic lakeside amphitheater. 
Figure 2.40- Norton Commons Town Plan. (Source: Norton Commons LLC, 2016)

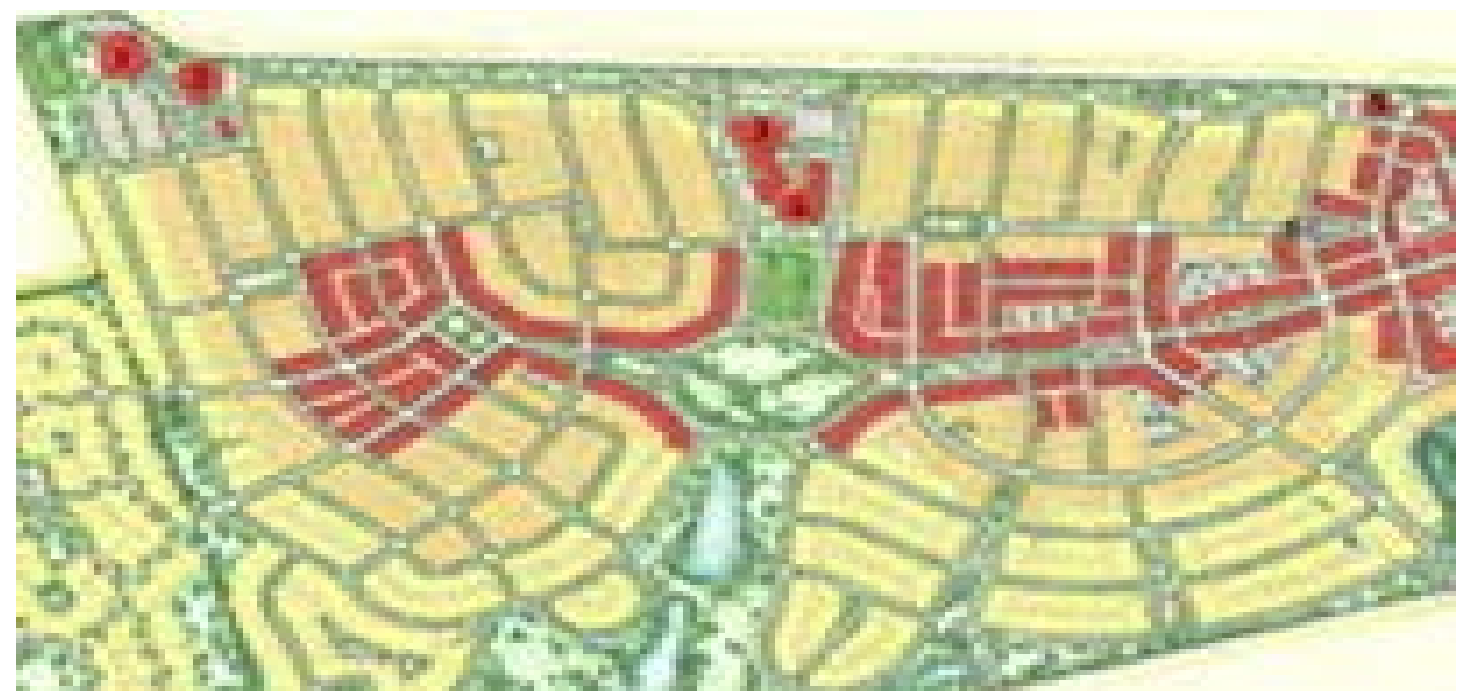

Figure 2.50- Norton Commons’ 2016 Homearama Advertisement. (Retrieved October 28, 2016 from bing.com/images)

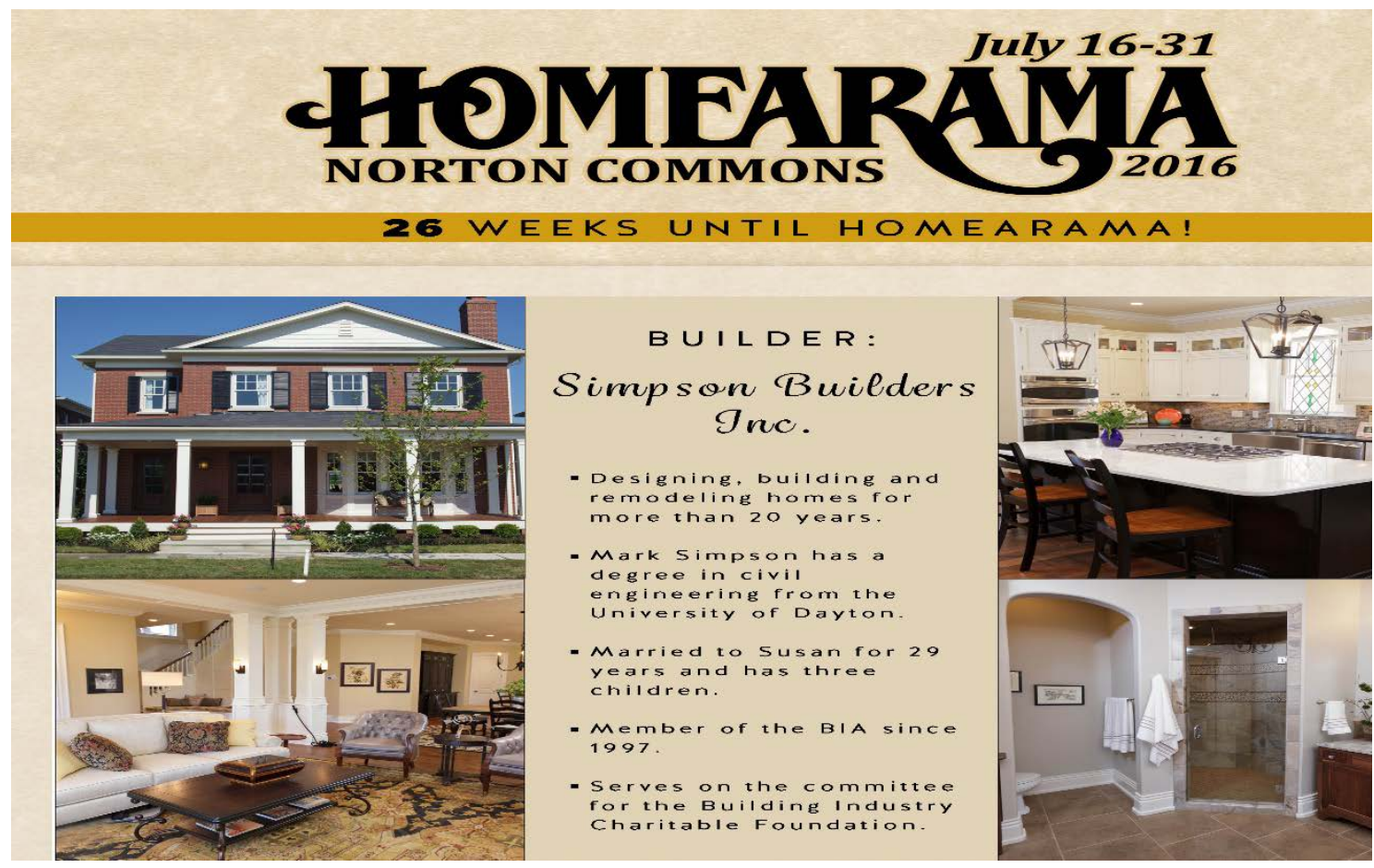


Figure 2.51- Upscale Amenities in Norton Commons. (Retrieved October 28, 2016, from bing.com/photos)

Top: Large mansion in Norton Commons.

Bottom: Norton Commons’ lakeside amphitheater.
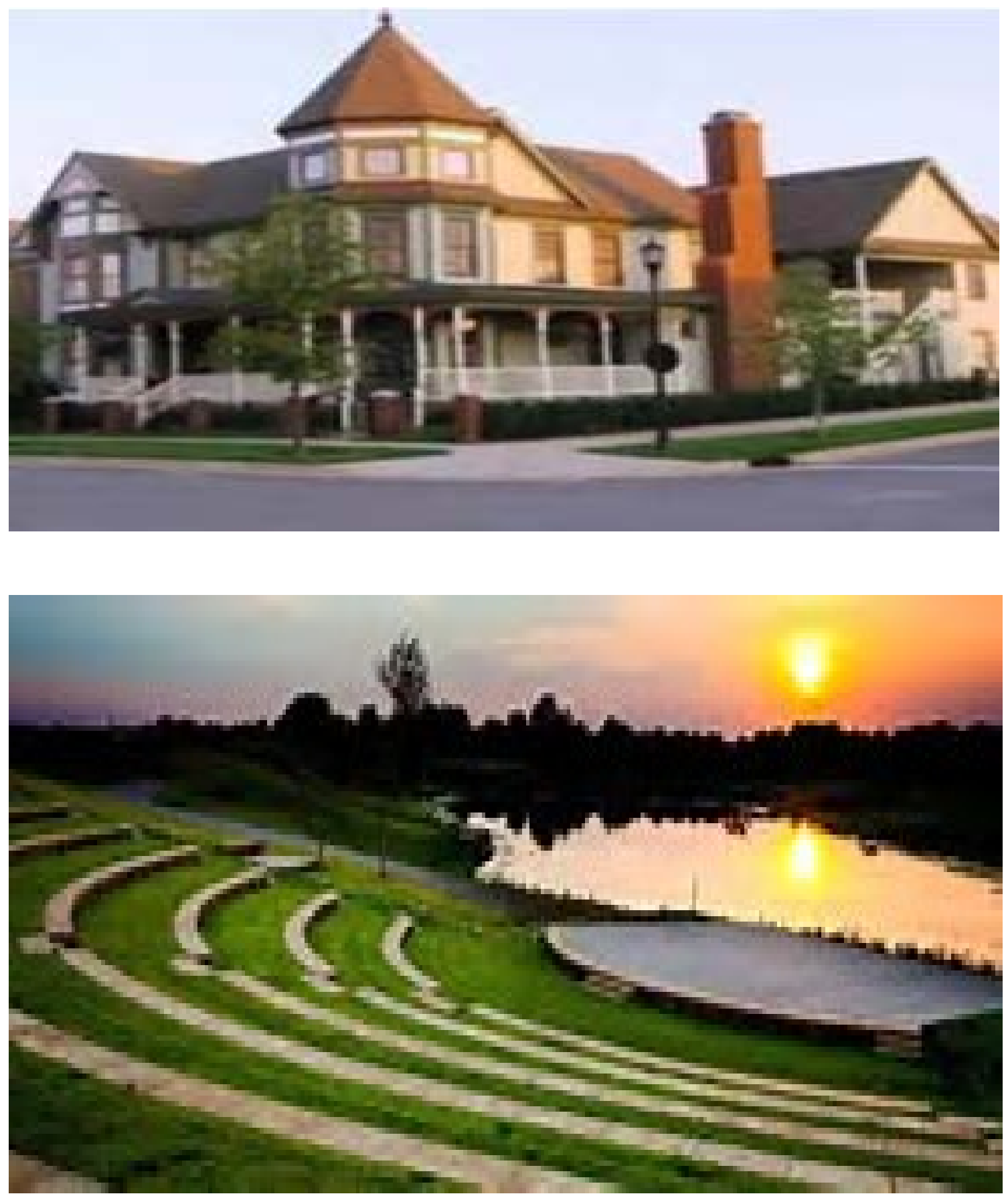
As is potentially the case with any neighborhood or area, the conditions in Norton Commons and northeast Jefferson County are not static. The Louisville Metro Government and Norton Commons are working together on a project to add 21 threebedroom apartments affordable to households making between \$28,000 and \$44,000 annually ${ }^{3}$. Within the context of this study, most of this housing would be categorized as lower middle-class housing, rather than low-income housing. However, these price points are likely significantly more affordable than typical housing in Norton Commons, given the "upscale” focus of the neighborhood. As such, efforts will be made in the presentation of results in this study (to be discussed more in the "Methodology" chapter) to reflect how the addition of this housing may impact the mix of income within the neighborhood. While Norton Commons deserves credit for what is a clear attempt to take progressive action (whether or not it will be effective is open to debate, but certainly, the intentions appear to be good), most likely the impact it has on the mix of income within the neighborhood will be minimal. Only a small portion of the neighborhood population that will be accounted for by this new housing. As such, these changes are unlikely to impact the appropriateness of Norton Commons serving as an example of the prototypical private New Urban neighborhood.

While Norton Commons is making an attempt to increase its affordable housing, it must be noted that there is severe opposition to this project from its residents. A neighborhood survey obtaining 100 responses, showed that 98 respondents opposed the project 3. Often reasons such as the potential decrease of property values or the

\footnotetext{
${ }^{3}$ Obtained from the website of local news station, WFPL. Ryan, J. September 14, 2016. "Fight over Affordable Housing Erupts in Norton Commons". WFPL.org.
} 
perceived inability of incoming residents to fit in were cited as motivation ${ }^{4}$. Many angry residents announced plans to bombard the development office with complaints and emails; some residents expressed disdain, feeling that they had earned Norton Commons' upscale environment, while believing these new residents are simply looking for a free ride $^{5}$. This attitude reflects something known as NIMBY-ism (an acronym for "not in my backyard"). This concept is a mentality in which residents do not mind the pursuits of a city, region, or other entity until it happens near where they live (Dear, 2007).

Ironically, this attitude is quite in line with the spirit behind exclusionary zoning and development. Such measures are in direct opposition to the goals of New Urbanism, in that exclusionary zoning constitutes a further proliferation of suburban exclusion (Pogodzinski, 2008). Exclusionary zoning, as a tactic, excludes certain types of land uses from a given community. The beginning of American suburbanization in the mid-20 $0^{\text {th }}$ century led to an increase in exclusionary zoning (King, 1978). Exclusion of low-income groups has often been achieved by setting standards such as minimum lot size and square footage for homes (Gyourko et al., 2008). Sentiments in Norton Commons sympathetic to exclusionary zoning indicate that New Urbanism may, at times, have to deal with a disconnect between the attitudes of the residents attracted to their neighborhoods and the goals of the movement itself.

However, to his credit, the Republican city councilman who represents Norton Commons has stated that he refuses to fight the project and that he believes that no community, anywhere, allows people to choose their neighbors ${ }^{6}$. Given that it is atypical

\footnotetext{
${ }^{4}$ Ryan, J. September 14, 2016. "Fight over Affordable Housing Erupts in Norton Commons". WFPL.org.

${ }^{5}$ Ryan, J. September 14, 2016. "Fight over Affordable Housing Erupts in Norton Commons". WFPL.org.

${ }^{6}$ Ryan, J. September 14, 2016. "Fight over Affordable Housing Erupts in Norton Commons". WFPL.org.
} 
for a Republican to stick up for a progressive cause in conflict with the interests of his own affluent constituency, such an action is particularly worth noting. The councilman's assertion is also backed up by legal precedent, which states that it is illegal for a neighborhood to exclude affordable housing options (Hochschild and Danielson, 1998). Thus, despite community unrest regarding the project, it must be assumed that these units will be constructed. While there may be many sociological questions as to how all of this process will play out, within the context of this study, the primary question about the housing project is how it impacts access to necessary facilities for low-income residents. There have also been recent regional events which will impact access in the northeastern portion of Jefferson County, where Norton Commons is situated. Interstate 265, an expressway that has long surrounded the outer edge of Jefferson County, was recently connected to Southern Indiana via a new bridge. It would be reasonable to expect that this bridge could radically accelerate development in the area beyond what it would have been otherwise. The bridge is tolled, and the development and access that are likely to result from the bridge would be what many urbanists may consider sprawling, undesirable development. However, for the purposes of this study, it must be acknowledged in some way how this new bridge may impact access.

The bridge development will come into play particularly in the regional portion of the study. Some accommodations can be made to the methodology to address this development, while there are also some limitations to the degree to which these changes can be captured. To address the range in which regional residents can access the respective neighborhoods of Clifton and Norton Commons by a short transit ride, the distance of this range has been extended to reflect the construction of the bridge. 
Addressing how long it may take for low-income residents in Norton Commons to reach major employment centers in Southern Indiana, through public transit, must be excluded from the study, however. This exclusion is necessary due to the lack of bus routes across the bridge. One such notable facility is Jeffersonville, Indiana’s Amazon Fulfillment Center, a facility with over 3,000 employers (there is also a satellite operation in Bullitt County, to the south of Louisville) $)^{7}$.

This chapter has provided background information on Louisville, Clifton, and Norton Commons, to provide context for the remainder of the study. The next chapter, Chapter III, will provide a review of the literature regarding the relationship between New Urbanism and some of the indicators that this study used to evaluate spatial social equity. Additionally, the review will cover the mechanisms behind grassroots neighborhood revitalization, as an alternative to New Urbanism in creating spatial social equity.

\footnotetext{
${ }^{7}$ Retrieved July 17, 2017, from integritystaffing.com. "Integrity Warehouse Jobs". Integrity Staffing Solutions.
} 


\section{CHAPTER III}

\section{LITERATURE REVIEW}

The forthcoming sections of this chapter discuss the relevant literature regarding New Urbanism and grassroots neighborhood organizations. As this dissertation deals with social equity, the next section evaluates the literature regarding New Urbanism's commitment to social equity. Additionally, the literature on the affordability, success at generating business, and transit-orientation of New Urbanism is covered in this section, as all of these arenas relate heavily with spatial social equity. Proxies for these considerations will be further detailed in the next chapter, the "Methodology" chapter.

The second section of this chapter deals with grassroots neighborhood organization. This paradigm is presented within this dissertation as an alternative to New Urbanism, in creating the urban atmospheres which cater to the spatial social equity for which New Urbanism advocates. As will be discussed further in the next chapter, it is hypothesized within this dissertation that the prototypical New Urban neighborhood will not achieve favorable results as it relates to spatial social equity. As an alternative to this movement, it is important to know the mechanisms by which grassroots organizations can potentially achieve success. This section discusses three ways in which neighborhood revitalization can occur: due to existing residents, due to the influx of bohemian outsiders, or due to outside organizations stepping in. Additionally, this section covers what strategies, economic models, and challenges may be part of the process of grassroots revitalization. 


\section{New Urbanism and Re-creating Urbanism from Scratch: What does it Provide the People?}

In addition to the Ahwahnee Principles, further understanding of the design mission of New Urbanism can be found through other sources, such as the Congress for the New Urbanism. CNU has outlined that New Urban communities should be aesthetically-sensitive to local architecture styles; possess higher density built environments; be transit and walker-friendly; create use policies which allow for a mix of non-residential land use, specifically civic and open spaces, along with multiple types of housing to create a demographically diverse place; designed consistent with regional progressive planning goals; and sensitive to environmental impact and the effort to promote environmental conservation and increase regional density (Congress for the New Urbanism, 1996). Slight variations may exist, but consistently embedded within goals attached to New Urbanism are aspirations for diversity of income, mixed use, and regional transit access-- all focal points of this study. Even today, the Congress for New Urbanism maintains its goals to create economically diverse neighborhoods, while claiming that any failure to accomplish this goal is a result of ineffective political environments (Congress for the New Urbanism, 2016).

Somewhat early into New Urbanism's tenure as an official design movement, Eppli and Tu established that the market value of New Urban homes was considerably higher than typical American housing (Eppli and Tu, 1999). Eppli and Tu determined that New Urban communities, when controlling for differences in building materials, square footage, and other factors, possess a 33 percent higher market value than property in surrounding areas (Eppli and Tu, 1999). In terms of the income of residents, early 
research on New Urbanism indicated that household incomes for New Urban residents ranged from 111,000 to 191,000 dollars a year (Converted to 2015 dollars; see Fulton, 1996). Scholars argue that trends toward expensive housing and affluent residents occur because the demand for walk-able urbanism is so high (Leinberger, 2007). Further, some question the legitimacy of the social goals of New Urbanism, arguing that it may simply be a design structure which allows developers to make more money by squeezing more property out of less land (Talen, 1999).

In scholarly evaluation, New Urbanism continues to be criticized for its lack of affordability. Talen has found that less than one percent of private New Urban communities have a single home which is affordable to lower income workers (Talen, 2010). Only 15 percent of private New Urban communities have a single home which is affordable to median income residents; while over 50 percent of homes, nationally, are affordable to median income residents (Talen, 2010). According to this research, New Urban communities have not only failed to achieve affordability for lower income residents, but they are also substantially less affordable than housing which might be found within general real estate. Evidence suggesting that New Urbanism's price points are unaffordable to most people has lead some scholars to conclude that the design movement simply produces affluent enclaves (Irazabal, 2012). Additionally, while not using a set of specific access indicators, as used in this study, Talen has formally addressed New Urbanism as it relates to the topic of social equity. Through qualitative research, she has noted the lack of social diversity in New Urban development designed to aid in the reconstruction of Post-Katrina New Orleans (Talen, 2008). 
While Talen's research most comprehensively lays out the lack of affordability of New Urban housing, additional scholarly work has further reinforced these findings. Derienzo refers to New Urbanism as a latte-on-demand design effort, given the interest in upper middle-class preferences in rebuilding Post-Katrina New Orleans (Derienzo, 2007). While Talen has effectively demonstrated that owner-occupied New Urban homes are unaffordable, there are indications that rentals may be unaffordable as well. Research of New Urban communities in Atlanta finds very few New Urban rental units to be at or below market rate (Prater, 2011).

Trudeau and Kaplan call into question the consensus that New Urban communities are unaffordable. Their research finds that private New Urban communities have similar levels of affordability to other communities within four miles (Trudeau and Kaplan, 2015). It must be noted, however, that these findings simply deal with the affordability of New Urbanism relative to other housing within a particular radius. Nothing about the methodology addresses New Urbanism's affordability specific to lower income residents. Nor can it necessarily be claimed that this relative affordability reflects a similarity in affordability to real estate at-large. Within Trudeau and Kaplan's study, the price points are unknown for the areas which surround the New Urban communities being evaluated.

There are components of New Urbanism which would appear to be geared towards affordability. It has been noted that one way in which New Urban communities seek to create income diversity is through creating a mix of housing types and sizes (Pyatok, 2000). It is further argued that New Urban communities can potentially offer more affordable living situations by reducing transit costs, and making living without a 
car feasible (Prater, 2011). Of course, the aforementioned literature has offered little to indicate that these theoretical conditions actually create affordable private New Urban communities. Even New Urban advocates find this lack of affordability problematic, arguing that without the presence of a variety of income groups, New Urban communities simply become yuppy theme parks (Walker, 2007).

New Urbanism is, in part, attempting to combat suburban patterns creating inaccessibility to daily goods, which often rely upon massive shopping centers to serve residents as far as 10-15 miles away (Hall and Porterfield, 2001). As New Urbanism was developing, research demonstrated that it had great potential to provide daily amenities within the neighborhood. Computer simulation suggested that New Urban residents would only use automobiles at 57 percent of the rate of residents of traditional suburbs (Kulash, Anglin, and Marks, 1990). Critics argued that such a reduction would not come to fruition in practice (Crane, 1994). Moreover, Fulton’s early assessment of New Urbanism concludes that there have often been inadequate attempts in attracting retail to NU communities (Fulton, 1996). However, later research has indicated that shopping, grocery stores, and libraries are accessed through walking at a much higher rate in New Urban communities than suburban communities (Nasar, 2003).

New Urbanism attempts to create a strong business and retail presence within neighborhoods through a variety of mechanisms. From early on in the movement, New Urbanists believed that they could strongly compete with the suburbs for residents and businesses through enriched environments, filled with arts districts, festival marketplaces, and parks (Bray, 1993). Bray argues that New Urbanism is providing a public service in creating such amenities, as in most metropolitan areas, the wealthy have taken their 
support from public spaces and institutions, instead dedicating it to their own ensconced areas (Bray, 1993). Beyond tangible resources, many urbanists would argue that such environments produced intangible benefits as well. Whyte argues that there are intelligence networks in clubs, restaurants and on street corners which lead to certain neighborhoods thriving in terms of the arts, entrepreneurialism, and innovation (Whyte, 1998).

Scholars have argued that conditions are ripe for New Urban communities to replace single-use suburbs. Grant argues that conditions in the United States are likely to favor less expensive, denser, and better-connected communities (Grant, 2013). Her research suggests that consumer patterns are trending in this direction, with consumer preference surveys indicating that people would choose urban options over suburban lifestyles (Grant, 2013). While the current suburban density range in America, of 1,0003,000, is below what is necessary to support regular bus service (Nelson and Sanchez, 2005), European cities such as London have increased the density in their suburbs to levels comparable to American central cities (Grant, 2013). Grant argues that achieving this level of density in American suburbs, through a means such as New Urbanism, is what will allow American suburbs to be successful (Grant, 2013).

Research has consistently shown that private New Urban communities are located in distant, suburban locations (Ellis, 2002) and frequently built near the edge of metropolitan areas. Talen has characterized private New Urban communities as typically located at least ten miles from downtown areas (Talen, 2010). Because the recognition of communities as being “New Urban” has substantive meaning, but is informal, as there is no registration for “New Urban” status, scholars frequently rely upon lists compiled by 
proponents of New Urbanism to evaluate these communities on a mass scale (Eppli and Tu, 1999; Talen, 2010). Recent documents suggest that the vast majority of New Urban communities are located in suburban towns within the MSA (in MSAs with at least one million residents), rather than the central city itself, further demonstrating the suburban nature of New Urbanism (The Town Paper, 2015). Additionally, most private New Urban communities may be located in mid-sized cities such as Louisville, given their typical location in cities of that size (Steuteville, 2014). Indeed, New Urban communities are developed at a disproportionally higher rate in metropolitan areas with populations between one and four million, compared to metropolitan areas with populations over four million (The Town Paper, 2015). The movement's prevalence in mid-sized cities is likely due to the largest American metropolitan areas having a stronger existing urban presence.

The most obvious criticism concerning the suburban location of private New Urban communities is the degree to which such a location may be disconnected from the urban core, and thus lack transit-friendliness. There are counterarguments to this concern, offered by New Urban proponents, as well as scholars. Although the location of private New Urban communities is frequently suburban, proponents of New Urbanism suggest that these communities can potentially serve similar purposes to the streetcar suburbs of the early $20^{\text {th }}$ century (Trudeau, 2013). Additionally, Bernick and Cervero contend that New Urbanism should only be viewed as a partial solution, to function in a broader planning context which supports it. They argue that transportation subsidies must be pursued for New Urbanism to succeed; and that in evaluating New Urbanism, it should be remembered that changes happen slowly and incrementally, and that it could 
take decades for these ideas to fundamentally change the metropolitan landscape (Bernick and Cervero, 1997).

Aspirations for suburban New Urban communities to function as streetcar suburbs are primarily meant to address transit-orientation. However, it is worth noting that as it pertains to income mixing, that streetcar suburbs were primarily populated by the middle class (Jackson, 1985). Additionally, New Urban proponents acknowledge that the movement will fail if it is primarily used to create better suburbs, rather than revive downtown areas (Fulton, 1996).

There are those who argue that the suburban nature of these communities is not problematic. Ellis suggests that as 95 percent of development occurs in the suburbs, New Urbanism becomes an effective means to counteract the single-use model (Ellis, 2002). He further argues that New Urban communities can accommodate a significant share of this suburban growth (Ellis, 2002). Proponents of New Urbanism see this potential impact on the suburbs as pro-active in combating laissez-faire urban design, when such design should be public and integrative (Sternberg, 2000).

It is argued by Steuteville (2015) that the suburban nature of New Urbanism is simply part of the four stages of evolution within New Urbanism, which will ultimately result in the movement's progressive goals being realized. Suburban New Urbanism, Steuteville argues, was Stage 1 in the process, in introducing an alternative to the traditional suburban model (Steuteville, 2015). Stage 2 was marked by the introduction of New Urbanism into existing urban areas, predominantly through the creation of Hope VI’s mixed-income communities (Steuteville, 2015). Stage 3 is characterized by sprawl repair, through retrofitting suburban shopping malls as mixed-use communities 
(Steuteville, 2015). Finally, Steuteville argues that Stage 4 is yet to occur, which will be when newly built street grids and urban design (created through New Urbanism, presumably) become as normal as they were 100 years ago (Steuteville, 2015). He acknowledges that this stage is decades away, as it will require transportation reform, and for multi-lane arterials to be narrowed, redesigned, and made walk-able (Steuteville, 2015). While New Urbanism has yet to reach the level projected by Steuteville, there has long been evidence of the spread of New Urbanism, as it spread into an international movement by the early 2000s (Smith, 2002).

Others argue that the purpose of New Urbanism is not necessarily to remove the automobile from daily life (Rahmana, Roshani, Hassani, and Seyed, 2012), as much other scholarship would suggest. Rahmana and his co-authors argue that New Urbanism instead attempts to create a scene of security, comfort, satisfaction, and convenience for pedestrians, as cars move along through the rest of the metropolitan area (Rahmana et al., 2012). In the process, however, they argue that New Urbanism can chip away at some of the destructive forces of sprawl, like the profliferation of parking spaces, the severe separation of uses, and the low density of buildings (Rahmana et al., 2012).

On the whole, however, the more knowledgeable the professional, the less likely they are to advocate for New Urbanism in reaching social and transit-oriented goals. Given the choice of other sustainable development models, such as "Smart Growth" and the "Ecological City", planning directors, planners, and academics found New Urbanism to be a less affordable model across income groups (Jepson Jr. and Edwards, 2010). When comparing planners to developers and designers, research suggests that planners have the lowest level of confidence in the idea of reorganizing sprawling Amercian 
suburbs into New Urban neighborhoods and districts (Garde, 2004). All three groups of professionals (planners, developers, and designers) agree that affordable housing cannot be implemented in New Urban design (Garde, 2004). These trends suggest that it is more of a priority to planners that New Urban communities meet an affordability threshold than is the case for developers and, perhaps more disconcertingly, New Urban designers.

It is important to note, however, that there is an alignment, and to some degree a partnership, between New Urbanism and other sustainable development movements like Smart Growth. The Congress of New Urbanism helped to found the Smart Growth Network, which has principles such as: 1) strengthening and directing development towards existing communities, 2) building walkable neighborhoods, 3) mixing land uses, 4) providing a variety of transportation choices, 5) creating housing opportunities and choices, 6) fostering attractive communities with a strong sense of place, and 7) encouraging citizen participation in development decisions (Poitcha, 2000). There are many commonalities between these Smart Growth principles and the principles of New Urbanism. Although there are exceptions to these principles which are not staples of New Urbanism, such as the focus upon existing communities and encouraging citizen participation in the development process. While the differences between New Urbanism and Smart Growth are outweighed by the similarities, it is possible that an ambivalence regarding existing communities and a lack of focus upon citizen participation could contribute to the lack of affordability which many scholars have attributed to New Urbanism. However, Walker notes that New Urbanism employs affordable housing strategies that are solely reliant upon design and top-down planning. These strategies include deed-restricted affordable housing and building cheaper interiors for their units 
(Walker, 2007). Such deed-restricted affordable housing practice provides a portion of the housing, such as 20 percent, at an affordable rate, while concealing the status (“affordable” versus "market-rate”) from the general public (Walker, 2007).

Areas near New Urban communities have largely been characterized as undeveloped agricultural land (Heid, 2004), and at times a mix of suburban development and farmland (Talen, 2010). While the environmental Ahwahnee Principles are beyond the scope of this study, it is pertinent to mention one such principle. This principle dictates that all New Urban communities should have a well-defined edge, protected from development, such as a greenbelt or wildlife corridor (Fulton, 1996). The idea of an edge separating the community from nearby development is further reinforced by founders of New Urbanism, insistent upon keeping everything on a neighborhood scale (Duany and Plater-Zyberk, 1994). New Urbanism not accounting for surrounding areas has drawn criticism from Talen, due to what is lost in this lack of inter-connection (Talen, 1999).

\section{Alternatives: Fixing the Existing City through Grassroots Efforts}

The literature on grassroots neighborhood revitalization suggests that it largely occurs in three different fashions: primarily through the efforts of existing residents; the influence of (often bohemian) outsiders who have moved into the neighborhood; or through outside activists or organizations who step in to train residents or improve distressed neighborhoods.

Talen refers to grassroots efforts among existing residents as DIY (do-it-yourself) urbanism, emerging from a mistrust and lack of faith in existing planning efforts, which frequently cede to business demands (Talen, 2014). Initially, this process began as neighborhood beautification (Talen, 2014). Neighborhood beautification was seen in 
cities such as New York, where redlined black neighborhoods would invest sweat equity, creating rooftop gardens, solar heating units, and windmills to power buildings (Boyte, 1980). Given the expansion of corporate governance in the 1970s, many communities created neighborhood-owned projects and community development corporations (Boyte, 1980). A particularly acclaimed example of existing residents affecting change in their own neighborhood was the Dudley Street Neighborhood Initiative in Boston, which began in 1984 (DSNI, 2015). This struggling black neighborhood which had been ravaged by disinvestment and arson (Soifer, 2014) sought to attract development while avoiding displacement (DSNI, 2015). Through a long list of ambitious principles, such as creating a community political voice, a fair and equal share of resources, and vibrant cultural diversity (DSNI, 2002), Dudley Street has achieved successes such as creating farmers' markets, increasing home-ownership, and tackling hazardous waste sites (DSNI, 2015).

These neighborhood activist efforts often form a neighborhood social safety net, of sorts. They are often guided by communal principles, such as if a neighbor helps you build your roof, then you owe it to the community to help another neighbor build his or her roof (Derienzo, 2007). These systems can potentially create more viable alternatives to top-down revitalization efforts, as resources tend to dry up for such ventures (Derienzo, 2007). However, while arguments are made that power or capital should be disseminated downward to the neighborhood level, some scholars argue that local grassroots organizations are often ineffective at governing (Warren, 2001).

Gentrification often becomes a concern for neighborhoods, out of fear that their community will be improved to the point to where existing residents will be priced out 
(Hartman, Keating, and LeGates, 1982). However, often through the grassroots efforts of bohemian outsiders, such improvements can often be beneficial to neighborhoods. This gentrification process, through the influx of outside residents, has revived neighborhoods such as Greenwhich Village in New York, Society Hill in Philadelphia, and Georgetown in the District of Columbia (VonHoffman, 2004). All of these neighborhoods were formerly known for concentrated poverty and substandard living quarters (VonHoffman, 2004). These outsiders are often attracted to the neighborhood by the potential they see in the amenities of these urban areas. Desirable amenities include old-fashioned buildings, art galleries, theaters, and restaurants (VonHoffman, 2004). The initial wave gentrification is often welcomed by existing residents, as neighborhood improvements happen at a manageable level, at this stage (VonHoffman, 2004).

The practice of outside organizations or activists stepping in to fight for neighborhood improvements can, in many ways, be attributed to Chicagoan Saul Alinsky. Alinsky focused on achieving social stability (in the case of his work, the increase of resources for poor, often black, neighborhoods) through negotiated compromises between power groups (in this case, "power groups" relates to a battle between a city hall, or corporation and a large, organized activist group, see Bailey Jr., 1974). Alinsky’s negotiations were based upon the premise that while City Hall and corporations have a lot of money, the resource of the have-nots is their large number of people (Alinsky, 1971). In his work, he would frequently win concessions from more traditionally powerful groups through organizing or threatening large, public nuisances (Alinsky, 1971). Chicago essentially became the home of the grassroots neighborhood movement. Alinsky left behind a legacy of many groups known as “Alinsky organizations”. These 
organizations such as NCO, SCC, OBA, and TWO sprang up across Chicago, representing various neighborhoods, alleviating feelings of powerlessness for their respective residents (Bailey, Jr., 1974).

In addition to secular organization, often neighborhood organization relies heavily upon local churches to spur community action. Social welfare, social action, and social advocacy, especially in African-American communities, often stems from organizations created through church involvement (Minkler and Wallerstein, 2012). Such efforts are a primary recourse of communities in fighting off market exploitation (Minkler and Wallerstein, 2012). Additionally, they are key to fighting off the destructive forces of privatism (Schragge, 2013). Along with charity institutions, the prominence of the church in expressing community organizing dates back to the 1960s (Schragge, 2013).

Some aspects of Alinsky's activist-mentality remain in current scholarship regarding community organizing. DeFillipis, Fisher, and Schragge argue that community-based activism and organizing is part of the key to challenging centers of global power, mobilizing resistance and opposition, and fighting neoliberalism (DeFillips, Fisher, and Schragge, 2010). They argue that in order to redistribute wealth and income, power must be redistributed to the working class, the poor, and groups that have faced oppression in modern capitalism (DeFillipis et al., 2010).

While some activist-mentality remains, in many ways, modern day organizations have moved towards an organizational-orientation, rather than the protest-orientation of the Alinsky era. Such was the case with the West DePaul neighborhood in Chicago, which sought to improve the neighborhood in a way that allowed for residential stability in the face of encroaching gentrification from surrounding areas (Peterman, 2000). In 
organizing CAN (West DePaul's neighborhood organization), Peterman trained residents on the basis of the principles of Pretsby and Wandersman, which include resource acquisition, organizational maintenance, production, and goal attainment (Pretsby and Wandersman, 1985).

In addition to the proliferation within Chicago, organizations have stepped up across the country, attempting to affect neighborhoods at the grassroots level, such as IAF (Industrial Areas Foundation) in El Paso (DeFillipis, 2001). In this region, outside attention was needed to address the economic fallout from the decimation of the area's garment industry, due to deindustrialization (Staudt and Stone, 2007). Struggling neighborhoods in St. Paul, Minnesota have been revived through a movement known as "Public Achievement”, which preaches the idea of civic engagement at a young age, in teaching $5^{\text {th }}$ to $7^{\text {th }}$ graders to build a playground. Public Achievement engaged in similar pursuits in ten different regions across America (Boyte, 2004). The organization ACORN was active in New Orleans in negotiating for struggling areas. This organization was quite versatile, as it successfully shifted from oppositional to reciprocal tactics, as the city shifted from an oil and gas regime to no regime (Burns, 2007).

The aforementioned literature on grassroots efforts indicates that they are frequently applied to urban areas; that these efforts are inclusive to lower economic groups; and that there are few limitations to how frequently these efforts can potentially be attempted, as the primary resource is people, rather than money. What is covered less tangibly are specificities about the degree to which such have an impact upon the spatial distribution of resources. Broad inferences can be made that it is ultimately the process 
of revitalization, resulting from neighborhood improvements, which signifies resource acquisition for a neighborhood.

The aforementioned literature also suggests that concerns arise when revitalization becomes gentrification. Despite concerns about potential displacement occurring from gentrification, research has shown existing residents do not leave a gentrified neighborhood at any higher of a rate than they do other neighborhoods (Buntin, 2015). This fact combined with the positive initial wave of gentrification identified by VonHoffman (2004) suggests that to a degree, gentrification could be a sign of the success of local grassroots efforts. Additionally, concerns over the potential fallout of gentrification are contested by observations that it rarely occurs (Ewalt, Freeman, and Poole, 1998). Ironically, given the typical opposition to gentrification, some suggest that the problem is that too few gentry typically migrate in for American neighborhoods to be turned around (Buntin, 2015). Nonetheless, VonHoffman lauds the positive effects of gentrification across America, arguing that it has not only occurred in the United States' largest cities, but also in smaller cities such as Milwaukee, Hoboken, and Providence (VonHoffman, 2004).

Grassroots neighborhood involvement, in theory, empowers local residents. Rosenblum (2000) argues that such associations create a pluralistic power distribution, contributing to the democratization of everyday life. Through such social networks, trust is built among people, potentially creating social capital and enhancing the quality of life for those involved (Stoecker, 1995). The idea behind gaining social capital, Hyman argues, is to access resources of a desirable level of quality, which are possessed by others (Hyman, 2002). Advocating for the development of community social capital is 
not hegemonic, however. Walsh argues that community-building for the purpose of gaining social capital assumes that community capacity for analysis, planning, and convening is essential for success (Walsh, 1997).

DeFillipis' Unmaking Goliath: Community Control in the Face of Global Capital highlights many of the strengths and weaknesses which come with turning community control over to the neighborhood. DeFillipis notes that many of the roots of community organization are race-based, in the form of African-Americans creating a common front to deal with the hostile, racist environment of the United States (DeFillipis, 2004). These organizations were able to pool their resources to create mutual neighborhood aid, to deal with the inequities they face in society (DeFillipis, 2004). DeFillipis notes that activism is a key component to the success of community organization. He argues that Chicago organizations were often militant, holding rent strikes, mobilizing protests, and creating picket lines (DeFillipis, 2004). However, in the 1970s, many of these organizations began functioning as CDCs, at which point they began to lack the vision to stave off decline (DeFillipis, 2004). This shift is potentially suggestive of the need for community organizations to keep an activist component to their goals.

DeFillipis further argues that the mutual aid roots of community organizing continue to play an important role in whatever successes neighborhood organizations might achieve. Housing collectives often can help to ward off gentrification, protecting displacement in the process (DeFillipis, 2004). There is evidence that worker-owned companies are more successful than competitors with traditional ownership (DeFillipis, 2004). Ultimately, DeFillipis argues that community organizations not only help to deal with issues confronted by the larger economy, but the lack of help from local 
governments as well. He calls for progressive decentralization, suggesting that the centralized nature of the governments of most major cities ensures that they will fail to meet the needs of struggling neighborhoods (DeFillipis, 2004). There are obstacles, however, to these organizations achieving these successes, as they are frequently heterogenous and end in conflict (DeFillipis, 2004).

Successful grassroots neighborhood organizations can supplement or replace local aid which communities typically count on receiving from the federal government. Prior to the widescale aid dispensed through the New Deal during the Great Depression, fraternal societies provided their members with health and life insurance benefits (Beito, 2000). Even when the federal government does come into play, one way in which community organizations are able to avoid the paternalism that may accompany this help is through the creation of mutual aid groups, with community members controlling the distribution of the resources (Williams, 1997). In such groups, there is a strong presence of participatory democracy, equality of member status, and cooperative decision-making (Williams, 1997).

As well as their obvious role in progressive politics, there is a conservative, neoliberal perspective on the role of grassroots efforts, as well. Some scholars hold the view that community action exists as collective action, with citizens mobilized by political calculations which are accompanied by risk (Warren, 2001). There are community strategies which operate in accordance with neoliberalism, such as the distribution of microcredit to distressed communities. These are loans provided to communities which are typically overlooked, with the hopes of spurring small business (Silverman, 2004). The intention is to move in the direction of market-based solutions 
for community revitalization, rather than adding to the social safety net (Silverman, 2004). The critiques of this solution center around it doing more for job creation than reducing area poverty, as well as connecting people to business more so than leading to civic or community-mindedness (Silverman, 2004).

DeFillips, Fisher and Schragge also take note of the neoliberal side of community development. These scholars argue that the general sentiment within community development corporations is that the market is the way to develop inner cities for the benefit of their residents (DeFillipis et al., 2010). There is often the assumption that the job of local economic development is to create wealth and jobs, in order to alleviate inner-city problems, such as affordable housing, unemployment, and poverty (DeFillipis et al., 2010). DeFillipis and his collaborators note that this paradigm is philosophically leftist, in that it seeks to promote equality and justice, but simultaneously leans heavily upon conservative principles (DeFillipis et al., 2010).

Financing for community development often focuses upon the built environment, but at times it can focus upon the residents of distressed communities themselves. Community Development Financial Institutions attempt to address issues regarding personal assets of neighborhood residents, as well as business development (Benjamin, Rubin, and Zulenbach, 2004). Concerns which CDFIs focus upon include the facts that low-income people without a savings or checking account are 43 percent less likely to have positive financial assets, 13 percent less likely to own a home, and eight percent less likely to own an automobile, than those who possess such transaction accounts (Benjamin et al., 2004). CDFIs also work to improve the housing and business climates of 
distressed neighborhoods, creating nonprofit loan funds which promote affordable housing and small business development (Benjamin et al., 2004).

The goals of such community development loans are extensive. Business Development Loan Funds provide capital to business and nonprofit organizations, many of which have not been able to qualify for funding from traditional sources, with the following goals in mind: 1) promoting economic growth and job creation in low-income areas, 2) stabilizing the decline of population in distressed communities, 3) improving the availability and quality of community facilities in underserved markets, 4) increasing the number of businesses owned, 5) increasing the number of businesses owned by women, and 6) and promoting the growth of businesses that do not harm the environment (Benjamin et al., 2004). Not all funding programs for community development are so extensive, as microenterprise funds only allow communities to be ten percent selfsufficient, due to the high administrative costs attached to these funds (Sewan, 1999). At times, micro loans may help to alleviate poverty by assisting low-income individuals in starting businesses (Benjamin et al., 2004). At other times these loans may be more intended for the general economic growth of an area, being awarded primarily to proven microentrepreneurs who have already been in business for several years (Else, 2000).

One of the primary qualities which proponents favor about grassroots community organization is the idea that neighborhood development is being pursued by the stakeholders themselves (Silverman, 2004). Interactions with resource-laden institutions are critical, but there is debate surrounding what these relationships should be. Some scholars feel that it is imperative for neighborhood organizations to build bridges to larger institutions (Gittel and Vidal, 1998). Alternatively, Gindin argues that the ultimate 
goal of organizing is to put pressure upon those with authority and power, in order to precipitate change (Gindin, 2002).

One of the largest challenges for grassroots efforts are questions about the ability of such movements to connect to power structures, such as government and corporations (Bordieau, 1985). Such connections are desirable to give neighborhoods the ability to leverage for political or economic benefit (DeFillipis, 2001). Additionally, Hays and Kogl argue that such relationships subtly benefit the larger power structure, placing the burden of provisions upon citizens (Hays and Kogl, 2007). Further, there is a danger of such efforts eroding into advocacy for volunteerism (Boyte, 2004) or conservative politics (Osman, 2008). Scholars have noted that on the whole, widespread success of grassroots efforts on the national level has been quite limited, occurring only during The Great Depression and The Civil Rights movement (Cloward and Piven, 1999).

Ultimately, DeFillipis has argued that the way for grassroots organizations to succeed is to discontinue their current reliance upon corporate negotiation, taking a more oppositional tact, while also ambitiously advertising the role which local efforts can play in the greater political economy (DeFillipis, 2001).

This need of grassroots organizations to connect to power structures, such as the government, is due to the power which these entities have and the potential impact of their policies. O’Connor notes that large-scale government policies often overwhelm small-scale intervention efforts (O’Connor, 2008). Unfortunately, one reason that community developers frequently fail to get the backing of governmental policy is that the residents of their communities are often not the type of constituency which typically woos politicians (O’Connor, 2008). 
A final challenge for grassroots community efforts is the lack of longevity for such movements. Speer and Hughes argue that the most critical element in empowering community organizations is to assure that there is a sustained activity and participation level (Speer and Hughes, 1995). Galbraith argues that sustaining the existence of such organizations is dependent upon the extent to which members collectively pursue a common goal or purpose (Galbraith, 1983). Ultimately, the end goal of any grassroots movement, in fighting through the obstacles which exist, is to strengthen the resources of the neighborhood in question. As Kelly argues, the process of organizing for power can potentially create social intervention which alters the flow of resources (Kelly, 1992). In many ways, making certain that the flow of resources reaches lower-income residents is a major component of this study. The methodology behind measuring Clifton and Norton Commons' success at this goal will be covered in the next chapter. 


\section{CHAPTER IV}

\section{METHODOLOGY}

The primary focus of this chapter is to specify research questions and measures to compare Norton Commons and Clifton in potential spatial contributions to social equity at the neighborhood, inter-neighborhood, and regional levels. The independent variable in this study is the type of community being evaluated: New Urban community (Norton Commons) or existing urban neighborhood (Clifton). The dependent variable is potential spatial contributions to social equity. Specific measures and proxies of contributions for the neighborhood and inter-neighborhood comparison will be detailed in Tables 4.204.23 and in Table 4.3 for the regional comparison.

Additionally, this chapter will present the primary research questions, specific Ahwahnee Principles of interest, data collection and sources, major hypotheses of the study, benefits and limitations of the study, and IRB considerations.

\section{Primary Research Questions}

1) How do Norton Commons (New Urban community) and Clifton (urban neighborhood) compare in terms of provisions for social equity at the neighborhood level?

2) How do Norton Commons and Clifton compare in terms of provisions for social equity at the inter-neighborhood level?

3) How do Norton Commons and Clifton compare, regionally, in the capability to serve people from all income groups? 


\section{Relevant Ahwahnee Principles}

Ten of the fifteen principles within New Urbanism's Ahwahnee Principles have some relationship with social equity while the other five are primarily environmental. Table 4.1 includes the Ahwahnee Principles to be used as guidelines for establishing provisions for social equity at the neighborhood and inter-neighborhood level. The following subsections explains how they will be measured. Please note: the principle numbers will not be presented sequentially, as environmental principles are excluded.

Table 4.1- Ahwahnee Principles Used.

\begin{tabular}{|c|l|}
\hline $\begin{array}{c}\text { Principle } \\
\text { Number }\end{array}$ & \multicolumn{1}{c|}{ Description } \\
\hline 1 & $\begin{array}{l}\text { All planning should be in the form of complete, integrated } \\
\text { communities, containing the shops, workplaces, schools, } \\
\text { parks, and civic facilities essential to the daily life of its } \\
\text { residents. }\end{array}$ \\
\hline 2 & $\begin{array}{l}\text { Community size should be designed so that housing, daily } \\
\text { needs, and other activities are in easy walking distance of } \\
\text { each other. }\end{array}$ \\
\hline 3 & $\begin{array}{l}\text { As many activities as possible should be located within } \\
\text { easy walking distance from each other. }\end{array}$ \\
\hline 4 & $\begin{array}{l}\text { A community should contain a wide range of economic } \\
\text { groups, income levels, and age groups to live within the } \\
\text { boundaries. }\end{array}$ \\
\hline 5 & $\begin{array}{l}\text { Businesses in the community should provide a range of job } \\
\text { types within the community. }\end{array}$ \\
\hline 6 & $\begin{array}{l}\text { The location and character of the community should be } \\
\text { consistent with a larger transit network. }\end{array}$ \\
\hline 7 & $\begin{array}{l}\text { The community should have a center focus which } \\
\text { combines civic, cultural, and recreational uses. }\end{array}$ \\
\hline 9 & $\begin{array}{l}\text { The community should contain an ample supply of green } \\
\text { space, in the form of squares, greens, and parks whose } \\
\text { frequent use is encouraged through placement and design. }\end{array}$ \\
\hline & $\begin{array}{l}\text { Public places should be designed to encourage the presence } \\
\text { of people at all hours of the day or night. }\end{array}$ \\
\hline
\end{tabular}




\begin{tabular}{|l|l|}
\hline 11 & $\begin{array}{l}\text { Streets, pedestrian paths, and bike paths should contribute } \\
\text { to a system of fully connected and interesting routes to all } \\
\text { destinations. Their design should encourage bicycle and } \\
\text { pedestrian use by being small and spatially-defined by } \\
\text { buildings, trees, and lighting, and by discouraging high- } \\
\text { speed traffic. }\end{array}$ \\
\hline
\end{tabular}

Proxies will be created for these principles to the degree that it is practical and efficient to do so. It is important to note that the primary purpose of the proxies created is to provide further measure of provisions that can potentially contribute to social equity. The Ahwahnee Principles are a solid guideline for provisions for social equity, and relevant, as they are intended to be guidelines for New Urbanism (Fulton, 1996).

All principles will be addressed in the measures to some degree, but certain omissions are necessary. For example, as it relates to Principle 4, this study is interested in income, so the age element of this principle will not be included in the data-collection. Also, the degree to which there is a mix of housing prices can be measured without using census data, which is not the case for age. As the boundaries created by census tracts problematically alter the boundaries of the neighborhoods being compared in this study, census data cannot be used as the basis of neighborhood and inter-neighborhood information. Additionally, while demographic measures such as gender and race provide information regarding the diversity of the neighborhoods, they encounter similar censusrelated problems. Furthermore, gender and race are not part of the Ahwahnee Principles and are therefore beyond the scope of this study. Finally, measuring these demographics does not deal with the issues of access for low- income groups, due to immobility, in the same direct fashion that occurs when making income the primary demographic evaluated in the study. 
As for Principle 9, the nature of this study requires the use of certain tangible and specific proxies while other elements may not be relevant in the focus of the present analysis. For example, while bicycle and pedestrian use will be examined, data on routes, lighting, and other complex-to-measure aspects of this principle will not be part of the analysis. Principles 2 and 6 will be thoroughly acknowledged in this study but will not have their own measures. The scale of the neighborhoods involved assumes walk-able access (Principle 2), while consistency within a larger transit network will be covered within the regional comparison (Principle 6).

\section{Neighborhood-to-Neighborhood Comparison}

Tables 4.20-4.23 demonstrate the basis for determining whether Norton Commons or Clifton is superior in possessing provisions that can potentially contribute to social equity. The amenities in these tables that serve as proxies for social equity are being established using New Urbanism’s Ahwahnee Principles as a general guideline. The amenities to be included in this comparison will be explained in the "Data Collection/Sources” section of this chapter. As the amenities range widely in the degree of their potential contributions to social equity, they have been categorized according to level of importance: “central”, “high”, “medium”, and “minimal importance”. “Central importance” is used to describe amenities that involve the existence of housing affordable to lower income groups as low-mobility, low-income groups must first be able to live in a neighborhood to gain any benefit from it. "High importance” amenities refer to

provisions that address essential daily needs. "Medium importance” amenities have some importance but do not directly provide for essential needs. "Minimal importance" 
amenities potentially contribute to social equity to a minimal degree or are theoretical in nature.

A list of amenities and their descriptions is given in Tables 4.20-4.23. Please note: each organizational or business establishment can be, and often will, counted for two purposes---first for the service that it provides and, second, as a potential employer. For example, while establishments such as "bars” are given low priority from the consumer, the same establishment will also be classified as an "unskilled job facility" which is a high priority from an employment perspective. Also with regard to employment, though there is the potential for employment opportunities in private homes, these will not be included as a site for employment in the presentstudy due to the difficulty in determining this information. Table 4.4 in the "Data Collection/Sources" portion of this chapter provides specifics on how the data was collected and cataloged along with additional data sources for secondary data.

Table 4.20- Central Importance Indicators (Methods).

\begin{tabular}{|l|l|}
\hline Amenity & \multicolumn{1}{|c|}{$\begin{array}{c}\text { Description/Justification } \\
\text { for Place in Hierarchy }\end{array}$} \\
\hline $\begin{array}{l}\text { General percentage of houses } \\
\text { affordable to below average } \\
\text { income residents. }\end{array}$ & $\begin{array}{l}\text { Priced below } \$ 150,000 \text {. Establishes } \\
\text { the possibility that all income } \\
\text { groups can live in the neighborhood. } \\
\text { Basis for threshold given in follow- } \\
\text { up discussion. }\end{array}$ \\
\hline General percentage of rental & $\begin{array}{l}\text { Rent under } \$ 850 / \text { month. Establishes } \\
\text { the possibility that all income } \\
\text { units affordable to below }\end{array}$ \\
average income residents. & $\begin{array}{l}\text { Basis for threshold given in follow- } \\
\text { up discussion. }\end{array}$ \\
\hline
\end{tabular}




\begin{tabular}{|l|l|}
\hline $\begin{array}{l}\text { Percentage of two-bedroom } \\
\text { houses affordable to below } \\
\text { average income residents. }\end{array}$ & $\begin{array}{l}\text { Priced below } \$ 150,000 \text {. Establishes } \\
\text { option for low-income residents } \\
\text { which have family needs. No } \\
\text { change in threshold as criteria for } \\
\text { low income does not change. }\end{array}$ \\
\hline $\begin{array}{l}\text { Percentage of two-bedroom } \\
\text { rental units affordable to below } \\
\text { average income residents. }\end{array}$ & $\begin{array}{l}\text { Rent for under } \$ 850 / \text { month. } \\
\text { Establishes option for low-income } \\
\text { residents which have family needs. } \\
\text { No change in threshold as criteria } \\
\text { for low income does not change. }\end{array}$ \\
\hline $\begin{array}{l}\text { Percentage of three-bedroom } \\
\text { houses affordable to below } \\
\text { average income residents. }\end{array}$ & $\begin{array}{l}\text { Priced below } \$ 150,000 \text {. Establishes } \\
\text { option for low-income residents } \\
\text { which have family needs. No } \\
\text { change in threshold, because criteria } \\
\text { for low income does not change. }\end{array}$ \\
\hline $\begin{array}{l}\text { Percentage of houses affordable } \\
\text { only to extremely affluent } \\
\text { residents (less is better). }\end{array}$ & $\begin{array}{l}\text { Priced above } \$ 400,000 \text { or twice over } \\
\text { the price that is affordable to the } \\
\text { average Louisville household. }\end{array}$ \\
& $\begin{array}{l}\text { Establishes the degree to which the } \\
\text { neighborhood has ensconced itself } \\
\text { in affluence. }\end{array}$ \\
\hline
\end{tabular}

Table 4.21- High Importance Indicators (Methods).

\begin{tabular}{|l|l|}
\hline Amenity & \multicolumn{1}{|c|}{$\begin{array}{c}\text { Description/Justification } \\
\text { for Place in Hierarchy }\end{array}$} \\
\hline Number of grocery stores. & $\begin{array}{l}\text { Establishes access to goods for daily } \\
\text { needs }\end{array}$ \\
\hline $\begin{array}{l}\text { Number of convenience/drug } \\
\text { stores. }\end{array}$ & $\begin{array}{l}\text { Establishes access to goods for daily } \\
\text { needs. }\end{array}$ \\
\hline Number of clothing stores. & $\begin{array}{l}\text { Establishes access to goods for daily } \\
\text { needs. }\end{array}$ \\
\hline $\begin{array}{l}\text { Number of potential small } \\
\text { employers for unskilled labor } \\
\text { class. }\end{array}$ & $\begin{array}{l}\text { Establishes existence of local job } \\
\text { market for low-income jobs. Further } \\
\text { description in follow-up discussion. }\end{array}$ \\
\hline Number of potential medium- & $\begin{array}{l}\text { Establishes existence of local job } \\
\text { market for lower income jobs. Further } \\
\text { description in follow-up discussion. }\end{array}$ \\
\hline labor. & $\begin{array}{l}\text { Public transit is the primary form of } \\
\text { accessing other parts of town for those } \\
\text { who cannot afford an automobile. }\end{array}$ \\
\hline Number of bus stops. & \\
\hline
\end{tabular}




\begin{tabular}{|l|l|}
\hline Number of libraries. & $\begin{array}{l}\text { The public electronic access provided } \\
\text { by libraries and other resources allow } \\
\text { low-income residents the necessary } \\
\text { access and ability to seek better jobs. }\end{array}$ \\
\hline
\end{tabular}

Table 4.22- Medium Importance Indicators (Methods).

\begin{tabular}{|c|c|}
\hline Amenity & $\begin{array}{c}\text { Description/Justification } \\
\text { for Place in Hierarchy }\end{array}$ \\
\hline Number of restaurants. & Recreational amenity. \\
\hline Number of schools. & $\begin{array}{l}\text { While it may be ideal for schools to be } \\
\text { located in the neighborhood, the } \\
\text { existence of districts and the school } \\
\text { bus system often makes it less of a } \\
\text { priority than other amenities. }\end{array}$ \\
\hline $\begin{array}{l}\text { Number of miscellaneous } \\
\text { business establishments. }\end{array}$ & $\begin{array}{l}\text { A general representation of the variety } \\
\text { of consumer goods available---not a } \\
\text { primary priority as daily need is not } \\
\text { established. }\end{array}$ \\
\hline $\begin{array}{l}\text { Total number of retail/business } \\
\text { establishments. }\end{array}$ & $\begin{array}{l}\text { A representation of the volume of } \\
\text { consumer goods available in the } \\
\text { neighborhood. Does not establish } \\
\text { daily need. }\end{array}$ \\
\hline $\begin{array}{l}\text { Percentage of houses classified } \\
\text { as average income. }\end{array}$ & $\begin{array}{l}\text { Houses priced } \$ 150,000-\$ 200,000 \text {. } \\
\text { Indicative of income mixing but does } \\
\text { not directly provide access to essential } \\
\text { provisions. }\end{array}$ \\
\hline $\begin{array}{l}\text { Percentage of rental units } \\
\text { classified as average income. }\end{array}$ & $\begin{array}{l}\text { Rent between } \$ 850-\$ 1,250 \text {. Income } \\
\text { mixing variable. }\end{array}$ \\
\hline $\begin{array}{l}\text { Number of potential small, } \\
\text { skilled-labor employers. }\end{array}$ & $\begin{array}{l}\text { Income mixing variable---might } \\
\text { attract middle-class to above middle- } \\
\text { class residents to neighborhood as a } \\
\text { result of obtaining job. }\end{array}$ \\
\hline $\begin{array}{l}\text { Number of potential medium- } \\
\text { sized, skilled-labor employers. }\end{array}$ & $\begin{array}{l}\text { Income mixing variable---might } \\
\text { attract middle-class to above middle- } \\
\text { class to neighborhood as a result of } \\
\text { obtaining job. }\end{array}$ \\
\hline Number of parks. & Recreational amenity. \\
\hline $\begin{array}{l}\text { Number of museums, } \\
\text { recreation centers, and } \\
\text { miscellaneous civic facilities. }\end{array}$ & Cultural/recreational amenities. \\
\hline
\end{tabular}




\begin{tabular}{|c|c|}
\hline Number of community centers. & $\begin{array}{l}\text { Can potentially be seen as a forum for } \\
\text { community action, but while } \\
\text { meaningful, it does not inherently } \\
\text { provide a tangible daily need. }\end{array}$ \\
\hline $\begin{array}{l}\text { The proportion of streets that } \\
\text { have sidewalks. }\end{array}$ & $\begin{array}{l}\text { It is important to have a walkable } \\
\text { design, but it would be difficult to say } \\
\text { that some gaps in walkable design } \\
\text { entirely impede residential access. }\end{array}$ \\
\hline $\begin{array}{l}\text { The proportion of streets that } \\
\text { have bike lanes. }\end{array}$ & $\begin{array}{l}\text { Encouraging bike use does contribute } \\
\text { to a larger street design system which } \\
\text { may provide residents with affordable } \\
\text { inter-neighborhood transit, increasing } \\
\text { mobility in the process. This inidcator } \\
\text { could be placed as a higher priority, } \\
\text { but it is difficult to quantify the degree } \\
\text { to which the lack of bike lanes } \\
\text { altogether stops someone from using a } \\
\text { bike to gain access. }\end{array}$ \\
\hline
\end{tabular}

Table 4.23-. Low Importance Indicators (Methods).

\begin{tabular}{|c|c|}
\hline Amenity & $\begin{array}{l}\text { Description/Justification } \\
\text { for Place in Hierarchy }\end{array}$ \\
\hline $\begin{array}{l}\text { Total number of } \\
\text { bars. }\end{array}$ & $\begin{array}{l}\text { A proxy for putting eyes on the street late at } \\
\text { night; based largely upon Jacobs' work (Jacobs, } \\
\text { 1961). While its importance cannot be } \\
\text { completely dismissed, the impact upon safety is } \\
\text { indirect and theoretical. It is difficult to assess } \\
\text { the degree to which bar-presence actually impacts } \\
\text { crime. }\end{array}$ \\
\hline $\begin{array}{l}\text { The proportion of } \\
\text { amenities, other } \\
\text { than housing, on } \\
\text { streets located } \\
\text { primarily within } \\
500 \text { feet of the } \\
\text { neighborhood } \\
\text { center point. }\end{array}$ & $\begin{array}{l}\text { This measure assesses convenience to a degree, in } \\
\text { that it is the most efficient way to } \\
\text { comprehensively minimize walking distance for } \\
\text { residents. However, since all amenities within } \\
\text { these neighborhoods are theoretically within } \\
\text { walking distance of each other, it is difficult to } \\
\text { argue this indicator does as much to create } \\
\text { accessibility as other proxies. }\end{array}$ \\
\hline $\begin{array}{l}\text { The proportion of } \\
\text { streets that have } \\
\text { automobiles lanes } \\
\text { (lower is better). }\end{array}$ & $\begin{array}{l}\text { It may be preferable for residents to not walk on } \\
\text { roads with heavy automobile traffic. The degree } \\
\text { to which automobile lanes would impede a } \\
\text { pedestrian from achieving access is minimal } \\
\text { compared to other amenities. }\end{array}$ \\
\hline
\end{tabular}


For efficiency purposes, data not obtained through secondary sources were obtained through a simple count. Although such a method may cause some degree of loss in data specificity, it allows for this study to be more comprehensive. Thus, the intention is to avoid anything that requires complex or subjective categorization. The classification of each amenity is provided in Appendix A. Ambiguity regarding the type of business of a recorded establishment was resolved through consultation of the company/organization's website.

Talen’s (2010) New Urbanism affordability study evaluating loan approval processes established a range of housing prices affordable to a teacher in the South. This salary level was used as a proxy for middle-income housing for this study. As Talen's study did not include rental properties, a median level apartment rental price was created through the common practice for measuring rental affordability by taking the median household income for Louisville (United States Census Bureau, 2010) and dividing it by three. The middle range for the purposes of this study are rentals between 80 and 120 percent of this figure. Rents for lower income residents are defined as rents below this range and rents for residents with above-average income are rents above this range.

Business and organizational establishments can be, and often were, classified for two different purposes within this study: once from a consumption perspective and, second, from an employment perspective. For example, a restaurant would be counted both as a restaurant and a potential unskilled labor facility, whereas a law firm would be counted as both a miscellaneous business establishment and a potential skilled labor employment facility. Some concessions must be made in order to create these measures. For example, a law firm may also have a cleaning crew, and a highly-successful owner of 
a restaurant may have more in common with the middle- or upper-class residents of a community as compared to its low-income residents. Classifications, however, were completed based on the most likely, predominant skill-level of the employees. Churches were excluded from consideration as potential job sites as it is unclear to what degree the workers may be volunteers. This study focuses upon paid employment.

Due to the sociological definition of "small" firms having less than 100 employees, “medium”-sized firms having between 100 and 5,000 employees, and "large” firms having over 5,000 employees (Hodson and Sullivan, 2012, pp. 375-376), the neighborhood and inter-neighborhood portions of this study must rely upon sizes of these establishments being classified as "small” or “medium”. Nationally, some firms in question may qualify as "large” firms, but the establishments will be classified as "small” for the purposes of this study. For example, McDonald’s is obviously a large, global corporation, but the number of jobs available at a single job site would classify it as a “small” establishment. As this study is interested in single worksites or establishments, the threshold for large is not likely to come into play, as this volume of employees often refers to the number of employees for a large corporation across multiple sites. Louisville has eight firms with over 5,000 employees locally. Only one is located near either Clifton or Norton Commons which is the Brownsboro division of Norton Healthcare. For these purposes, establishments ranging in size from restaurants up to department stores will be classified as "small”, as they are unlikely to employ more than a hundred employees at a single site. Employment sites that are much larger, such as factories or hospitals, will be classified as “medium-sized” (as opposed to large, given that Norton Healthcare’s employment base is spread out over several sites). 
While "large" job sites were excluded from the neighborhood and interneighborhood portion of the study, they were used in conjunction with medium-sized sites in the regional comparison (to be discussed in a later section of this chapter) due to the need to look at the largest employment sites in the region. These classifications are provided for descriptive purposes and for improving the accuracy of measuring the employment landscape. This study does not seek to make any normative judgments as to which size workplace is more desirable. Skill level is measured as either "skilled" or "unskilled". "Skilled” refers to skill levels beyond "unskilled". "Skilled” positions encompass fields that are categorized within work sociology as semi-skilled up to professional, encompassing workers from hair stylists up to doctors (Hodson and Sullivan, 2006, pp. 194-195). The purpose for this broad range is based upon the notion that lack of mobility, as it relates to reaching workplaces, is most likely to affect the poorest employees, and arguably those without credentials or training for other jobs (Dreier et al., 2014).

Descriptive data is provided by industry type in Chapter V, as defined by Hodson and Sullivan (2006). The Northern American Industrial Classification System (NAICS) was consulted when there was confusion as to what type of industry a given business constitutes.

\section{Potential Inter-Neighborhood Contribution}

As articulated in Chapter III's literature review, it is not a priority for New Urban communities to connect with nearby communities (Talen, 1999). As nearby neighborhood boundaries are easily penetrable (Peterman, 2000), this lack of connection 
can deprive both the neighborhood of concern and nearby neighborhoods of the mutual benefits that would derive from the additional access to amenities in both communities.

To compare what might be gained through such connections, nearby areas were treated as potential expansions of the neighborhoods, with the intent of expanding the end-to-end walking distance of the neighborhoods by five minutes (to stay within reach of a walkable scale). The Clifton Community Council describes extensive city council relationships, day-to-day operations, and local business exchanges as occurring between Clifton and surrounding neighborhoods to the north, Clifton Heights, and to the east, in Crescent Hill. To approximate the scale desired for this portion of the study, the parameters of investigation were extended outward by $1 / 6$ of a mile into each of these neighborhoods. Doing so involved evaluating all of the roadways that exist within this range for each of these neighborhoods.

To offer a similar comparison in Norton Commons, the areas $1 / 6$ of a mile to the west and the south of Norton Commons were evaluated as these areas are most accessible to pedestrians and most likely to possess the amenities of interest. One of these areas is a suburban subdivision called "Wolf Trace”. Wolf Trace extends somewhat beyond the extended point westward, but some land to the south of this subdivision will be lost for comparison, as it is a country road that separates the land in a way not suitable for these measures. Therefore, for simplification purposes, the westward connection was defined as this subdivision which is a close approximation of the area this portion of the study seeks to evaluate. The area to the south of Norton Commons is a straight measure of areas within the 1/6-mile extension that encompasses a suburban shopping area. Some consideration was given to the possibility of measuring nearby areas in all four directions 
(north, south, east, west) for each neighborhood, in order to remove personal judgement. However, the areas to the north and east of Norton Commons have minimal development. In addition, given road crossings, pedestrian access may not be feasible and amenities would be difficult to measure on foot. Likewise, Clifton has neighboring areas that are less favorable for this measurement as well. The area south of the neighborhood and Interstate 64 is consumed disproportionately by cemetery space and less accessible to pedestrians than other nearby areas. This highway obstruction is seen in Figure 4.3 below. So with practicality in mind, the most objective compromise was to measure the two directions for each neighborhood that would be most favorable for this comparison. In Norton Commons' case, the existence of development to the west and south satisfies this criterion. While Clifton has development to the west, north, and east, the northern and eastern areas relate most with the grassroots inter-neighborhood connections which Clifton has established. 
Figure 4.3- Street Map of Clifton. Boundaries of Brownsboro Road to the north, Ewing Avenue to the east, I-64 to the south, and Melwood Avenue to the west. (Retrieved October 26, 2016, from bing.com/images, “Map of Louisville”)

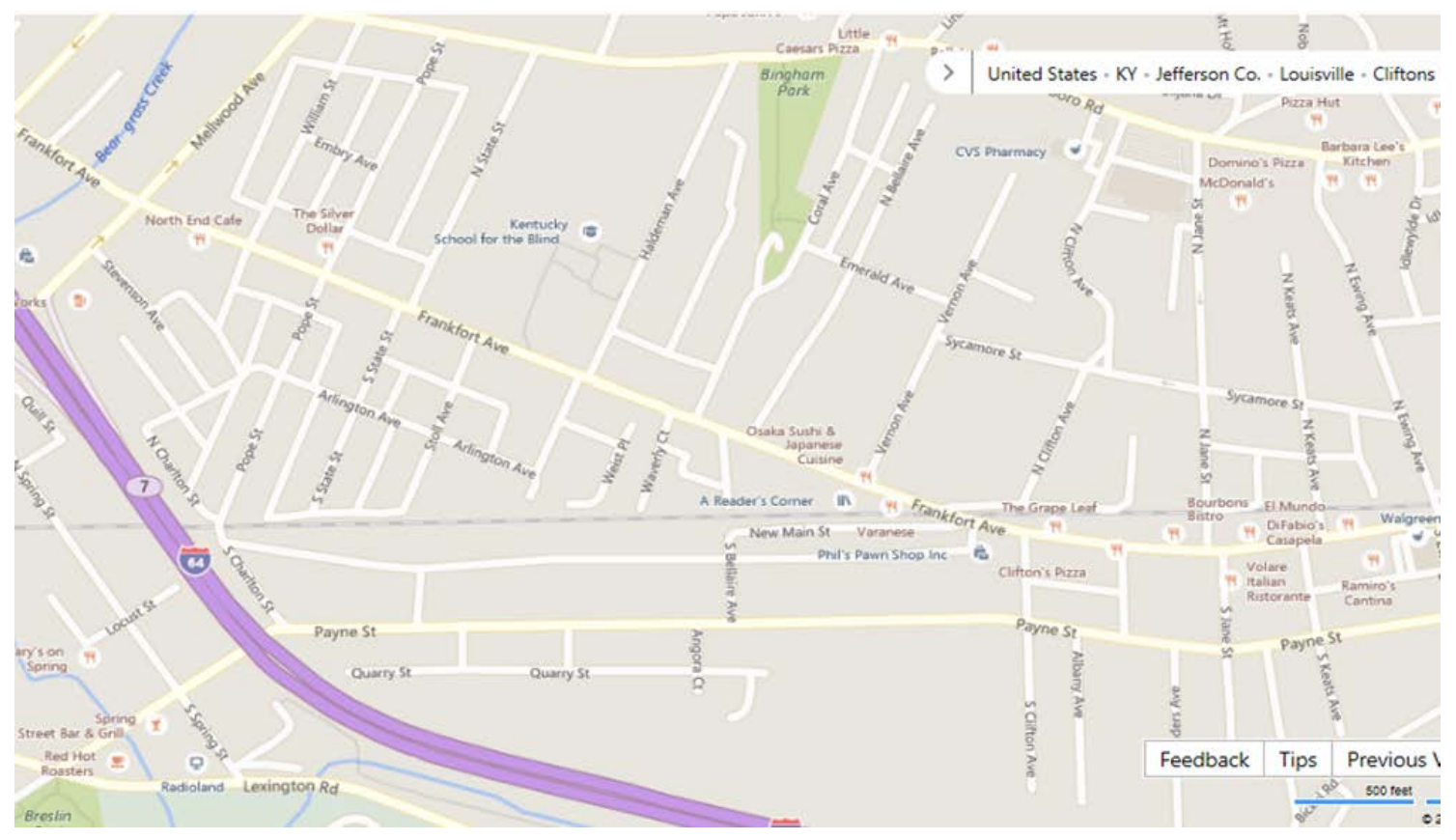

The nearby areas of Norton Commons and Clifton were evaluated using criteria specified in Tables 4.20-4.23, similar to the neighborhood comparison. The basic tenets of what constitutes potential contributions to social equity within a small area remains the same for these areas. The measure of the central location of amenities will be omitted as it is not applicable to this portion of the study. While it is possible for pedestrians to traverse back and forth between Norton Commons and its nearby areas, the walkways are more challenging than what might be expected for an area that anticipates walking between neighborhoods. The suburban subdivision to the west has to be walked to by way of roundabout, while the suburban shopping to the south requires walking along the shoulder of the road. Nonetheless, it was feasible, so these nearby areas were included in the study. 


\section{Regional Comparison}

Given that scholars have long argued that poor urban residents face difficulty in accessing suburban amenities (Wilson, 1987 and 1996; Jargowski, 1997; Dreier, et al., 2014), this comparison seeks to evaluate several factors concerning accessibility: the ability of urban residents to reach each neighborhood through public transit; how many people within Louisvillecan conveniently reach these neighborhoods through public transit and the economic groups these people come from; and finally, the accessibility that low-mobility residents in each of these neighborhoods have to major unskilled labor facilities in the county through public transit. As Chapter II noted, there are some unskilled labor facilities of note that are located outside ofJefferson County within the metropolitan area, but they did not meet the size criteria which was established for this portion of the study.

The first step in measuring regional access is to determine the transit time from the urban core. Far from a matter of small inconvenience, if extremely inefficient public transit in automobile-based mid-sized cities leads to arduously-long transit times, it can make it more difficult for a low-income resident to achieve upward mobility if he/she cannot afford an automobile (Dreier et al., 2014). Transit times were obtained through the website for the Louisville regional bus system, Transit Authority of the River City or TARC. The point of measurement was from $6^{\text {th }}$ and Market Street to the neighborhoods in question. This starting point straddles the central business district and the eastern edge of Louisville’s most concentrated high-poverty areas (Louisville GIS, 2015). This location is a compromise between downtown and the concentration of Louisville's urban poor. The rationale for measuring transit times in this fashion is rooted in the argument 
that suburban development contributes to a reverse commute for poor urban residents as unskilled labor jobs are moved to hard-to-reach suburban locations. Within the confines of this argument, the nature of the relationship for these two neighborhoods in Louisville may be adequately generalized to many American cities as poor, decimated urban cores and distant, suburban New Urban communities are common conditions in metro areas across the United States.

Another measure was needed to address the accessibility of jobs through public transit for each of these neighborhoods at the regional level. Due to the limitations as to how many job locations can be practically measured, this study focused upon four large employment facilities from three of Louisville's top ten employers. These employers and worksites were chosen as they offer predominantly unskilled positions in fields such as manufacturing or package-handling which is in keeping with the focus of studying access for low-income residents (who are likely candidates for these types of positions). The four facilities examined include: United Parcel Service (UPS) WorldPort; Kentucky Truck Plant and Louisville Assembly Plant (both Ford Motor Company sites); and General Electric Appliance Park. Each of these facilities employs at least 4,000 workers. Each of these companies actually employs at least 9,000 workers within Louisville, when both of Ford's facilities are combined (Louisville Metro Chamber of Commerce, 2016). As Chapter II noted, in addition to these facilities, the new I-265 bridge provides road access to an Amazon Fulfillment Center in Southern Indiana, which could also provide a large number of jobs to unskilled workers. However, due to the bus not travelling across this bridge, this facility has been excluded from the study. 
Given the tendency for New Urban communities to distance themselves from development and regional transit networks, it is worthwhile to see the degree to which residents in each of these neighborhoods can access major employers through public transit. Some complexities exist, in analyzing this type of access, that have implications for relating these findings to larger urban phenomena. It has been argued that employment within the metropolitan area is becoming decentralized and increasingly suburbanized in recent decades (Tomer, 2012). The location of these major employment locations within Louisville shows this decentralized pattern, as these locations are between five and 15 miles to the south or east of downtown. Suggesting that communities should be oriented towards existing employment potentially advocates that community development chase suburban development patterns. Few people in urban circles would suggest such a pursuit as a means to holistically create a sustainable development pattern. However, despite this decentralization of employment and the complications that come with measuring regional employment access, research has shown that public transit riders in suburban locations still have more difficulty accessing employment than urban riders (Tomer, 2012). Thus, a comparison of neighborhood regional employment access remains warranted.

The second part of the regional comparison involves assessing how many people and what economic demographics are able to feasibly access each neighborhood through public transit. For this assessment, demographics were evaluated by looking at all census tracts that are located within five miles of each neighborhood. A five-mile radius was used to ensure that the radius does not allow exorbitantly long transit times. As Trudeau and Kaplan (2015) found that New Urban communities have similar housing prices to 
properties within a four-mile radius and Talen (2010) found that private New Urban communities are almost universally unaffordable to even the middle class, research suggests that there may be an affluent homogeneity to the areas within four miles of New Urban communities. For these reasons, a four-mile radius would have been ideal, but a compromise was made in the choice of a five-mile radius. This decision was made to account for all areas that are substantively relevant to this portion of the study.

Also, only a half-circle for each neighborhood could be used for the regional comparison. A geographical boundary for Clifton, in the form of the Ohio River, makes the area to the north of Clifton unsuitable for comparison. While there is a significant amount of development directly across the river, the road systems provide less of a direct route, due to the interruption of the river. Given its potential to adversely affect the meaningfulness of the data, this area was excluded from the study. Thus, the area examined from Clifton includes a half-circle of areas within a five-mile radius to the west, south, and east.

The most favorable direction for Norton Commons, in this regard, is the area to the west of the neighborhood. Norton Commons' region was measured within a fivemile radius to the west, north, and east. The recent extension of the regional beltway, Interstate 265, provides Norton Commons with a direct connection to Utica, Indiana and parts of Jeffersonville, Indiana which are both directly across the Ohio River. There is greater income diversity in these areas of Indiana than other areas near Norton Commons (such as the remainder of Prospect and a significant portion of Oldham County, which represent the third-most affluent community in Kentucky and the state’s most affluent county, respectively; see United States Census Bureau, 2010). One complication is that 
the new bridge has a toll, which does not necessarily conform with providing access for low-income residents. However, if residents were to use the TARC bus system to cross the bridge, this access is toll free.

The findings to be presented in accordance with Table 4.3 represent the focal points for this regional comparison. These indicators evaluate the degree to which each community’s provisions can potentially contribute to social equity regionally and access regional necessities. Once again, all data that is reflective of greater access for lower income groups will be considered favorable findings for the purposes of this study. From Table 4.3, the total number of census tracts (likely to differ between communities as there is always some variation in census tract area) is provided solely for descriptive purposes.

Table 4.3-. Regional Comparison (Methods).

\begin{tabular}{|l|l|}
\hline Measure & Notes \\
\hline Transit time from urban core. & Regional access measure. \\
\hline $\begin{array}{l}\text { Transit time to major unskilled } \\
\text { job facilities. }\end{array}$ & Regional access measure. \\
\hline Total number of census tracts. & Descriptive statistic. \\
\hline Total number of households. & $\begin{array}{l}\text { Number of households potentially able } \\
\text { to access the neighborhood within the } \\
\text { designated transit radius. }\end{array}$ \\
\hline $\begin{array}{l}\text { Proportion of census tracts } \\
\text { with high poverty level }(25-\end{array}$ & $\begin{array}{l}\text { At least twice the poverty level of } \\
\text { Louisville’s average. Concentrated } \\
\text { poverty indicator. }\end{array}$ \\
\hline $\begin{array}{l}\text { Proportion of census tracts } \\
\text { with extremely high poverty } \\
\text { level }(50 \% \text { or higher). }\end{array}$ & \begin{tabular}{l} 
Concentrated poverty indicator. \\
\hline $\begin{array}{l}\text { Proportion of census tracts } \\
\text { with a median household } \\
\text { income below } \$ 30,000 .\end{array}$
\end{tabular} \\
\hline $\begin{array}{l}\text { Proportion of census tracts } \\
\text { with a median household } \\
\text { income } \$ 30,000-\$ 50,000 .\end{array}$ & $\begin{array}{l}\text { Indicator of accessibility for distressed } \\
\text { areas. }\end{array}$ \\
\hline $\begin{array}{l}\text { Proportion of census tracts } \\
\text { with a median household } \\
\text { income above } \$ 50,000 .\end{array}$ & $\begin{array}{l}\text { Indicator of accessibility for middle } \\
\text { income areas. }\end{array}$ \\
\hline
\end{tabular}




\begin{tabular}{|l|l|}
\hline $\begin{array}{l}\text { Proportion of census tracts } \\
\text { with a median household } \\
\text { income above } \$ 100,000 .\end{array}$ & $\begin{array}{l}\text { Indicator of the degree to which } \\
\text { community is ensconced within other } \\
\text { relatively affluent communities. }\end{array}$ \\
\hline
\end{tabular}

\section{Data Collection/Data Sources}

A significant portion of the data for the neighborhood and inter-neighborhood comparisons was gathered through primary data collection. This gathering was done through a simple count system for each street in the neighborhoods and their nearby areas. A form was developed that was used for each street to compile this data. Using fictional entities as examples, Table 4.4 illustrates a sample data collection form for one street.

Table 4.4- Primary Data Collection Tool.

\begin{tabular}{|c|c|c|c|c|}
\hline Street & $\begin{array}{l}\text { Number of } \\
\text { Bus Stops }\end{array}$ & $\begin{array}{l}\text { Sidewalk } \\
\text { Present? }\end{array}$ & $\begin{array}{l}\text { Bike Lane } \\
\text { Present? }\end{array}$ & $\begin{array}{l}\text { Automobile Lane } \\
\text { Present? }\end{array}$ \\
\hline $\begin{array}{l}\text { Johnson } \\
\text { Street, from } \\
\text { Miller } \\
\text { Street to } \\
\text { Simpson } \\
\text { Street }\end{array}$ & 1 & Yes & No & Yes \\
\hline $\begin{array}{l}\text { Business/ } \\
\text { Organiz- } \\
\text { ation }\end{array}$ & $\begin{array}{l}\text { Type of } \\
\text { Business/ } \\
\text { Organization- } \\
\text { al Establish- } \\
\text { ment }\end{array}$ & $\begin{array}{l}\text { Potential } \\
\text { unskilled } \\
\text { employer? }\end{array}$ & $\begin{array}{l}\text { Potential } \\
\text { small or } \\
\text { medium } \\
\text { employer? }\end{array}$ & Industry Type \\
\hline $\begin{array}{l}\text { Tarantino's } \\
\text { Pizzeria }\end{array}$ & Restaurant & Yes & Small & Personal Services \\
\hline $\begin{array}{l}\text { Green } \\
\text { Acres } \\
\text { Community } \\
\text { Center }\end{array}$ & $\begin{array}{l}\text { Community } \\
\text { Center }\end{array}$ & N/A & N/A & Government/Administrative \\
\hline $\begin{array}{l}\text { Barry’s } \\
\text { Market }\end{array}$ & Grocery Store & Yes & Small & Distributive Services \\
\hline
\end{tabular}




\begin{tabular}{|l|l|l|l|l|}
\hline $\begin{array}{l}\text { Rogers and } \\
\text { Clark Law } \\
\text { Firm }\end{array}$ & $\begin{array}{l}\text { Miscellaneous } \\
\text { Business } \\
\text { Establishment }\end{array}$ & No & Small & Professional Services \\
\hline
\end{tabular}

\section{$\underline{\text { Remaining Data Sources Used for Study- }}$}

1)House/Rental Prices: Housing data was obtained by using the website for Norton

Commons' real estate office and two other real estate websites, listed below. For housing and rental prices, it is not necessary to get a total count for each property within each price range; proportions will suffice (it also would be difficult to get the information needed due to limitations regarding the way census data is structured). Norton Commons advertises all homes that it has for sale, so the Norton Commons LLC website was used to determine the price ranges for homes in the area. The most extensive advertising source regarding home sales for the areas surrounding Norton Commons is the website trulia.com. The most extensive advertising source for homes for sale in Clifton, as well as its surrounding areas, is zillow.com.

For rental properties, zillow.com also has the most extensive listing of such properties for both Norton Commons and Clifton. There are no rental properties in Norton Commons’ surrounding areas and extremely limited information on rental properties for the small swath of land surrounding Clifton. Thus, comparing rental properties from the surrounding areas of these neighborhoods was omitted from the study.

While census data is available regarding housing and rental prices, using census tract information to measure these prices would greatly obscure the meaningfulness of any findings since the data from the census tracts as measured do not directly correspond to the units of measure being used in the current study. For example, the census tract for 
Norton Commons would include all of Prospect, a much larger community that includes Norton Commons as one component of its entire area. Using the census tract as the unit of analysis would lead to evaluating the New Urban neighborhood of Norton Commons while also including countryside mansions situated on enormous lots (throughout the rest of Prospect) as part of the neighborhood. Also, if consistency demanded that census tracts become the units of analysis for other elements of the study, rather than the neighborhoods, then the land area being evaluated would be so vast that walkable scale would no longer exist. Additionally, the feasibility of conducting the study could come into question. Census data also measures housing price in interquartile ranges which does not provide nearly the amount of information about the distribution of housing prices that this study demands. Thus, other methods of assessing the housing prices within these neighborhoods are needed.

2)Regional data- Transit times were collected through route information provided by TARC. United States Census Bureau data from 2010 was used for the remainder of the regional comparison.

\section{Hypotheses}

Hypothesis 1- Clifton (example of a viable urban neighborhood) compares favorably to Norton Commons (example of the prototypical private New Urban community) in terms of neighborhood provisions which contribute to social equity.

Justification: New Urbanism has struggled to provide affordable housing and serious questions have been raised about New Urbanism's ability to attract consumer goods facilities and business. In addition, New Urbanism's relative lack of emphasis upon density could potentially impact the amount of amenities Norton Commons can support. 
Thus, it was expected that Norton Commons would have difficulty in comparison to Clifton as it relates to provisions of higher importance. Norton Commons may possibly be comparable to Clifton in terms of less important provisions that are heavily reliant upon design principles, a primary emphasis for New Urbanism (Talen, 1999).

Hypothesis 2- The nearby areas of Clifton will compare favorably to those of Norton Commons in terms of provisions which contribute to social equity.

Justification: New Urbanism does not make it a focus to develop in a manner in which nearby areas are a focal point for the daily operations of the neighborhood. The areas which surround New Urban communities are typically suburban or rural in nature, which likely limits the degree to which diverse housing options and provisions can exist compared to an urban environment.

Hypothesis 3- Clifton will compare favorably to Norton Commons in terms of capability to serve people from all income groups at the regional level.

Justification: The distant suburban locations of New Urban communities make them difficult for the urban poor to access through public transit. The research findings of Talen (2010) and Trudeau and Kaplan (2015) suggest that the communities that are in close transit range of New Urban communities may primarily be affluent in nature.

\section{Benefits of Research}

- Comprehensive evaluation of the degree to which a private New Urban community does or does not tangibly address social equity.

- Provides tangible, concrete standard for comparison for a New Urban community in the form of a viable urban neighborhood. Other dialogue regarding New Urbanism may promote the attitude, "New Urbanism has limitations, but it is better than the alternative".

- Through strong ties with the Ahwahnee Principles, the present study offers a look at the degree to which New Urbanism achieves its principles.

- Opens up future research possibilities regarding the tangible success of grassroots communities and provides a systematic examination of New Urbanism. 


\section{Limitations of Research}

- Offers a rough measure and less precision regarding price points of consumer goods, but provides some valuable data.

- Is unable to address the degree to which grassroots efforts have led to the amenities which exist in Clifton.

\section{IRB Considerations}

This study is exempt from needing IRB approval as there are no human subjects and the secondary data used is data which is readily available to the public. 


\section{CHAPTER V}

\section{NEIGHBORHOOD COMPARISON OF SOCIAL EQUITY INDICATORS FOR CLIFTON AND NORTON COMMONS}

This chapter discusses the findings regarding the spatially-oriented social equity indicators for Clifton and Norton Commons. In addition to presenting the findings, figures are displayed to demonstrate how Clifton and Norton Commons stack up proportionally for various indicators. For each category of indicators (central importance, high importance, medium importance, and low importance), analysis is provided as to what the findings mean in the larger context of New Urbanism and grassroots revitalization. Potential explanations for disparities within the comparison are also provided. These analyses are followed by a comprehensive analysis of the findings for Clifton and Norton Commons at the neighborhood level.

In addition to the points of comparison discussed in Chapter IV's methodological overview, for descriptive purposes, tables and figures are presented regarding the distribution of industries for the various employment sites within the dataset. Additionally, there is commentary regarding the relevance of this distribution of industry to the study. 


\section{Central Importance Indicators}

Table 5.1- Results for Central Importance Indicators of Social Equity at the Neighborhood Level ${ }^{8}$.

\begin{tabular}{|l|c|c|c|}
\hline \multicolumn{1}{|c|}{ Indicator } & Clifton & $\begin{array}{c}\text { Norton } \\
\text { Commons }\end{array}$ & $\begin{array}{c}\text { Projected } \\
\text { Norton } \\
\text { Commons }\end{array}$ \\
\hline $\begin{array}{l}\text { Percentage of } \\
\text { Houses }\end{array}$ & $31 \%$ & $0 \%$ & N/A \\
$\begin{array}{l}\text { Affordable to } \\
\text { Below Average } \\
\text { Income } \\
\text { Residents }\end{array}$ & & & \\
\hline $\begin{array}{l}\text { Percentage of } \\
\text { Rental Units } \\
\text { Affordable to }\end{array}$ & $67 \%$ & $0 \%$ & $1 \%$ \\
Below Average & & & \\
Income & & & \\
Residents & & & \\
\hline $\begin{array}{l}\text { Percentage of } \\
\text { Two- Bedroom }\end{array}$ & $36 \%$ & & \\
Houses & & & \\
Affordable to \\
Below Average & & & \\
Income & & & \\
Residents & & & \\
\hline $\begin{array}{l}\text { Percentage of } \\
\text { Two- Bedroom }\end{array}$ & & & \\
Rental Units & & & \\
Affordable to & & & \\
Below Average & & & \\
Income & & & \\
Residents & & & \\
\hline $\begin{array}{l}\text { Percentage of } \\
\text { Three- Bedroom }\end{array}$ & & & \\
Houses \\
Affordable to & & & \\
Below Average & & & \\
Income & & & \\
Residents & & & \\
\hline
\end{tabular}

${ }^{8}$ Most favorable results italicized.

${ }^{9}$ Projected percentages for Norton Commons following the completion of the neighborhood's affordable housing project. 


\begin{tabular}{|l|c|c|c|}
\hline Percentage of & $0 \%$ & $83 \%$ & N/A \\
Houses & & & \\
Affordable only & & & \\
to Extremely & & & \\
Affluent & & & \\
Residents & $0 \%$ & $0 \%$ & N/A \\
\hline $\begin{array}{l}\text { Percentage of } \\
\text { Rental Units }\end{array}$ & & & \\
Affordable only & & & \\
to Extremely & & & \\
Affluent & & & \\
Residents & & & \\
\hline
\end{tabular}

(Sources: Norton Commons LLC, zillow.com and trulia.com-retrieved September 20, 2016)

The findings indicate that nearly one-third of houses for sale in Clifton are affordable to below average income residents, while none are affordable to this group in Norton Commons. Thirty-six percent of two-bedroom houses for sale in Clifton are affordable to below average income residents, with 14 percent of the three-bedroom houses for sale in Clifton affordable to this group. The lack of houses in Norton Commons affordable to below average income residents is largely consistent with Talen’s (2010) findings that only one percent of private New Urban communities, nationwide, have a single unit affordable to lower income residents. Regarding rental units, Clifton's units are largely affordable to below average income residents, with about two-thirds of their apartments for rent affordable to this group. Norton Commons currently does not possess any rental property affordable to below average income residents. The projected total upon completing the neighborhood's affordable housing project would only bring this total to one percent of Norton Commons' total rental stock. 
However, none of the apartments affordable to below average income residents in Clifton have two bedrooms. Thus, there could be some difficulty in finding an apartment in Clifton for lower income residents with kids. Technically, Norton Commons scores more favorably for this indicator, as it is projected that two percent of the neighborhood's two-bedroom rental units will be affordable, upon completing the affordable housing project. Substantively, it is difficult to argue that this presence presents much of an advantage, as the number of such units will be minimal. There is certainly a degree of importance to having affordable rental property, as one of the fastest growing types of communities, in terms of poverty, are ones with high levels of families renting (Pendall et al., 2014). Given the pricing trends noted for New Urban rental units (Prater, 2011), it is unsurprising that Norton Commons has a dearth of affordable rental units, as well. Alternately, Clifton's general availability of houses and rental units for below average income residents is consistent with scholarship that suggests that revitalization only prices residents out of neighborhoods on rare occasions (Buntin, 2015).

The findings indicate that the vast majority, 83 percent, of Norton Commons' homes for sale are affordable only to extremely affluent residents (those with household incomes over twice the average for Louisville). No homes for sale in Clifton are in this prohibitive price range. This high price point for Norton Commons is unsurprising, given the demographic findings of Eppli and Tu's study regarding the market value of New Urban homes. Their findings indicate median household incomes ranging between 111,000 and 191,000 dollars (in 2015 dollars) for residents in the private New Urban communities which they studied (Eppli and Tu, 1999 and 2014). Such income levels are between two to four times the national median household income (United States Census 
Bureau, 2010). No apartments for either neighborhood are priced at levels only affordable to extremely affluent residents. Looking at housing for the two neighborhoods on the whole, findings indicate that it is significantly more likely that a below average income resident would be able to find housing in Clifton than Norton Commons. The lone exception to this trend is the lack of availability of two-bedroom apartments in Clifton that are affordable to this group, while a minimal influx of such apartments are expected to come to Norton Commons, upon completion of the neighborhood's affordable housing project. Additionally, the considerable presence in Norton Commons of homes affordable to only extremely affluent residents suggests the general price points of the neighborhood may be far from reaching affordability. While these housing indicators are of central importance to this comparison, it remains important to evaluate other indicators to see if Norton Commons is structurally compatible with spatial social equity should its housing become more affordable in the future.

\section{High Importance Indicators}

Table 5.2 - Results for High Importance Indicators of Social Equity at the Neighborhood Level.

\begin{tabular}{|l|c|c|}
\hline \multicolumn{1}{|c|}{$\begin{array}{c}\text { Spatial } \\
\text { Indicator for } \\
\text { Social Equity }\end{array}$} & Clifton & Norton Commons \\
\hline Grocery Stores & 2 & 0 \\
\hline $\begin{array}{l}\text { Convenience/Drug } \\
\text { Stores }\end{array}$ & 6 & 2 \\
\hline Clothing Stores & 2 & 22 \\
\hline $\begin{array}{l}\text { Potential Small } \\
\text { Employment Facilities } \\
\text { for Unskilled Labor }\end{array}$ & 55 & \\
\hline
\end{tabular}




\begin{tabular}{|l|c|c|}
\hline $\begin{array}{l}\text { Potential Medium- } \\
\text { sized Employment }\end{array}$ & 0 & 0 \\
$\begin{array}{l}\text { Facilities for } \\
\text { Unskilled Labor }\end{array}$ & & \\
\hline Bus Stops & 19 & 0 \\
\hline Libraries & 0 & 0 \\
\hline
\end{tabular}

(Source: Appendix A)

Figure 5.2- Neighborhood to Neighborhood Ratio of Select High Importance Indicators of Social Equity ${ }^{10} 11$.

Clifton- Blue, Norton Commons- Red

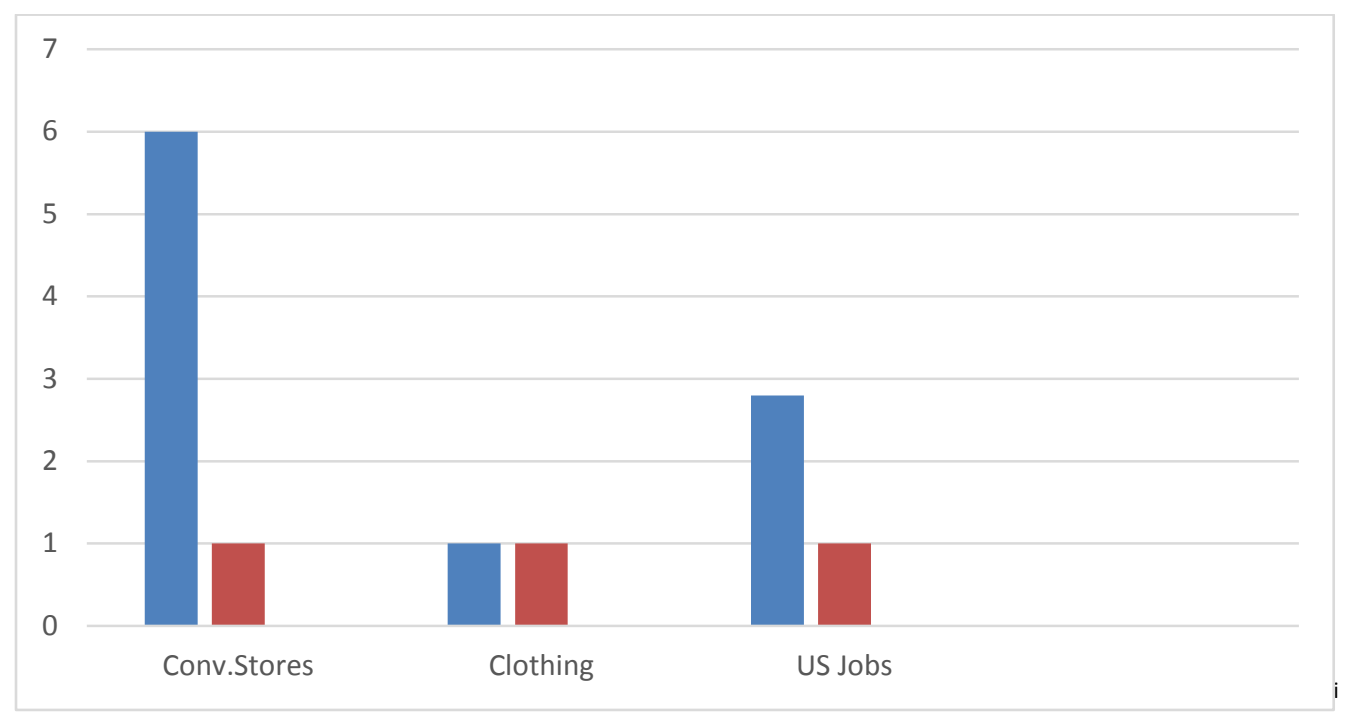

Regarding access to daily goods, Clifton fares better than Norton Commons in terms of grocery stores and convenience stores, while Norton Commons equals Clifton in terms of clothing stores. Clifton's two grocery stores, compared to none for Norton Commons, amounts to a significant advantage given the role that grocery stores play in

10“US Jobs" refers to potential small employment facilities for unskilled labor.

${ }^{11}$ In addition to the ratios listed above, Clifton has a presence of both grocery stores and bus stops, while Norton Commons has neither. 
meeting the daily needs of residents. Additionally, a six-to-one advantage for Clifton in terms of convenience/drug stores indicates that the neighborhood is significantly more equipped than Norton Commons to provide daily goods on a small scale as well. Norton Commons matches Clifton in having two clothing stores, but it would be difficult to argue that either neighborhood offers much in terms of clothing options. Neither neighborhood has a library, which could potentially pose difficulties for residents unable to afford the internet. As Chapter IV highlighted, electronic access is a central tenet to job searches in the $21^{\text {st }}$ century (Maurer, 2015). On the whole, Clifton has more favorable conditions for residents attempting to access daily goods within the neighborhood, while both neighborhoods have shortcomings in certain areas.

Clifton’s 55 small business establishments which serve as potential employment facilities for unskilled labor are two-and-a-half times the total of 22 for Norton Commons. Given the large numbers involved in this category, this ratio is particularly striking. Considering that residents employed in low-income, unskilled jobs are those most likely to lack an automobile, it is especially important that residents have access to such jobs at the neighborhood level. Clifton's relative superiority in this regard might partially be explained by having a stronger business presence than Norton Commons. This disparity may also reflect the types of businesses located in Norton Commons. Additionally, Clifton's 19 bus stops, compared to a complete lack of bus stops in Norton Commons, suggests that Clifton is much more transit-friendly than Norton Commons. This may put low-income residents in Clifton who need to seek employment outside the neighborhood at an advantage over such residents in Norton Commons. On the whole, low-income Clifton residents have a greater capability of accessing daily goods and 
employment within the neighborhood, as well as transit to meet needs outside of the neighborhood, than is the case for Norton Commons residents.

\section{Medium Importance Indicators}

Table 5.3- Results for Medium Importance Indicators of Social Equity at the Neighborhood Level.

\begin{tabular}{|c|c|c|c|}
\hline Indicator & Clifton & $\begin{array}{c}\text { Norton } \\
\text { Commons }\end{array}$ & $\begin{array}{c}\text { Norton } \\
\text { Commons } \\
\text { Projected } \\
\end{array}$ \\
\hline Restaurants & 26 & 9 & N/A \\
\hline Schools & 1 & 4 & N/A \\
\hline $\begin{array}{l}\text { Miscellaneous } \\
\text { Business } \\
\text { Establishments }\end{array}$ & 44 & 40 & N/A \\
\hline $\begin{array}{l}\text { Total Business } \\
\text { Establishments }\end{array}$ & 80 & 52 & N/A \\
\hline $\begin{array}{l}\text { Percentage of } \\
\text { Houses in } \\
\text { Middle Income } \\
\text { Range }\end{array}$ & $38 \%$ & $0 \%$ & N/A \\
\hline $\begin{array}{l}\text { Percentage of } \\
\text { Houses } \\
\text { Affordable to } \\
\text { Middle Income } \\
\text { Residents and } \\
\text { Below }\end{array}$ & $69 \%$ & $0 \%$ & N/A \\
\hline $\begin{array}{l}\text { Percentage of } \\
\text { Rental Units in } \\
\text { Middle Income } \\
\text { Range }\end{array}$ & $33 \%$ & $33 \%$ & $38 \%$ \\
\hline $\begin{array}{l}\text { Percentage of } \\
\text { Rental Units } \\
\text { Affordable to } \\
\text { Middle Income } \\
\text { Residents and } \\
\text { Below }\end{array}$ & $100 \%$ & $33 \%$ & $40 \%$ \\
\hline
\end{tabular}




\begin{tabular}{|c|c|c|c|}
\hline $\begin{array}{l}\text { Potential Small } \\
\text { Employment } \\
\text { Facilities for } \\
\text { Skilled } \\
\text { Employment } \\
\text { Only }\end{array}$ & 27 & 39 & N/A \\
\hline $\begin{array}{l}\text { Potential } \\
\text { Medium-Sized } \\
\text { Employment } \\
\text { Facilities for } \\
\text { Skilled } \\
\text { Employment } \\
\text { Only } \\
\end{array}$ & 0 & 0 & N/A \\
\hline Parks & 3 & 8 & N/A \\
\hline $\begin{array}{l}\text { Misc. Civic } \\
\text { Facilities }\end{array}$ & 9 & 5 & N/A \\
\hline $\begin{array}{l}\text { Community } \\
\text { Centers }\end{array}$ & 1 & 0 & N/A \\
\hline $\begin{array}{l}\text { Percentage of } \\
\text { Streets with } \\
\text { Sidewalks }\end{array}$ & $83 \%$ & $86 \%$ & N/A \\
\hline $\begin{array}{l}\text { Percentage of } \\
\text { Streets with } \\
\text { Bike Lanes }\end{array}$ & $0 \%$ & $0 \%$ & N/A \\
\hline
\end{tabular}

(Sources: Appendix A; Norton Commons LLC; zillow.com and trulia.com—retrieved September 20, 2016) 
Figure 5.30- Neighborhood to Neighborhood Ratio of Select Housing-Oriented Medium Importance Indicators of Social Equity.

Blue- Clifton, Red- Norton Commons Projected

\%AvgRent- Frequency of Middle Income Rent

\%AvgBelow- Frequency Middle Income Rent and Below

*In addition to average income rental units (and average income and below), Clifton possesses average income houses for sale, while Norton Commons has none.

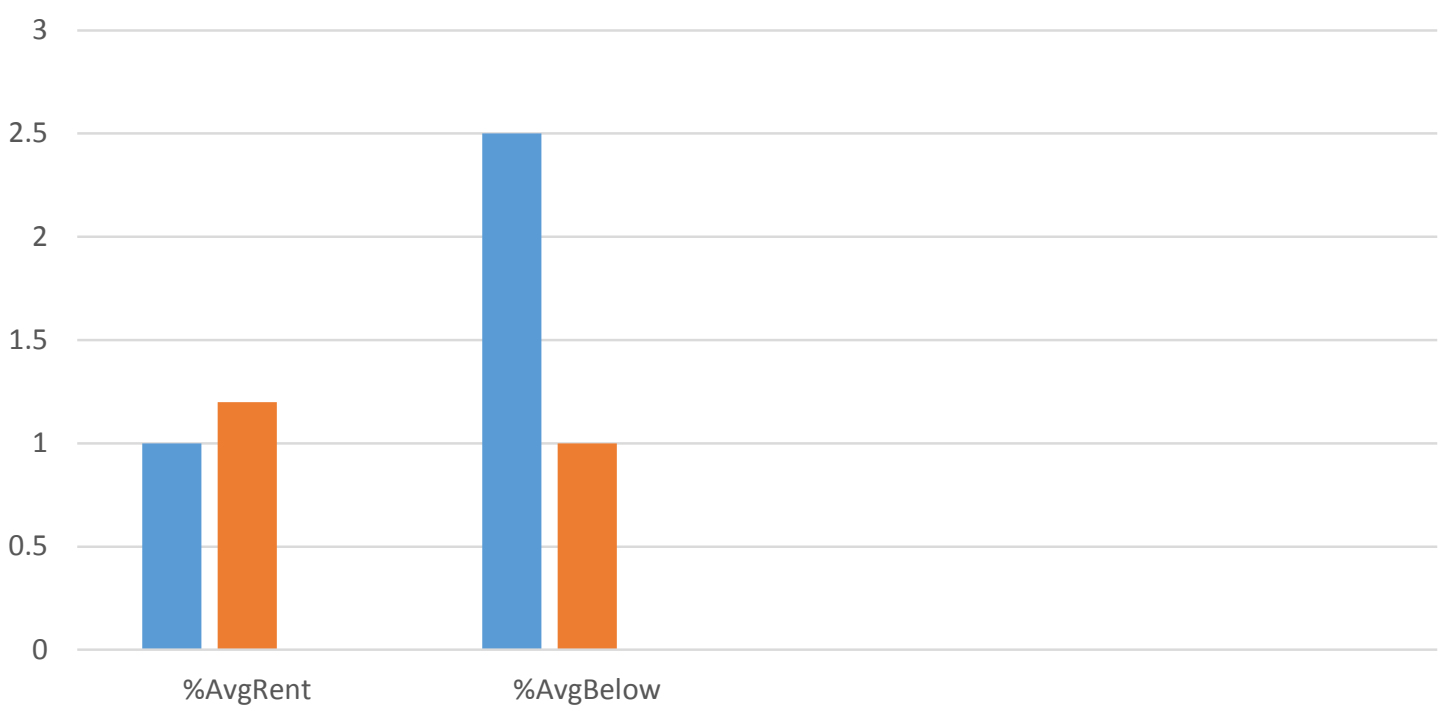


Figure 5.31- Neighborhood to Neighborhood Ratio of Select Employment-Oriented Medium Importance Indicators of Social Equity.

Blue- Clifton, Red- Norton Commons

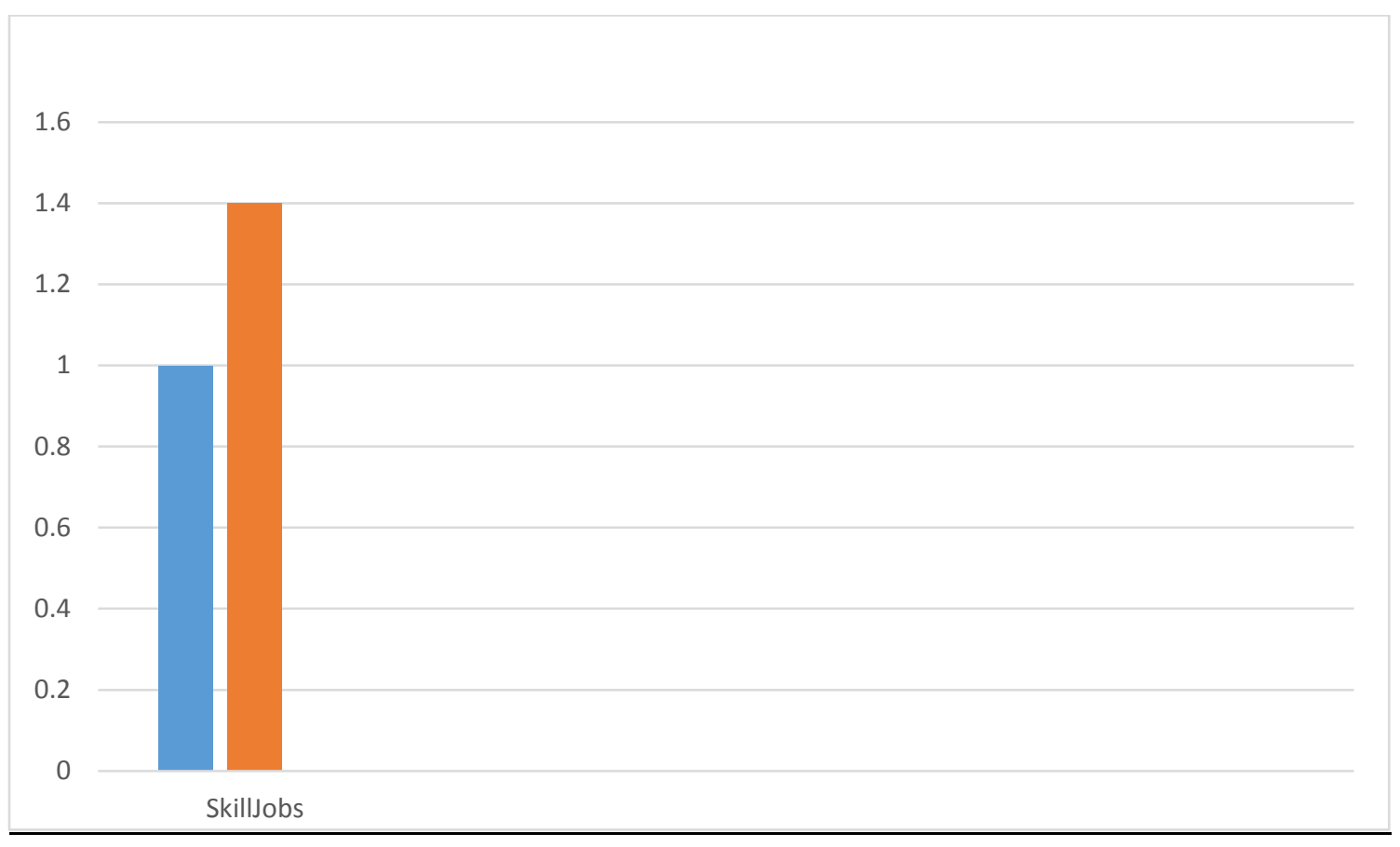


Figure 5.32- Neighborhood to Neighborhood Ratio of Select Amenity-Oriented Medium Importance Indicators of Social Equity.

Blue- Clifton, Red- Norton Commons

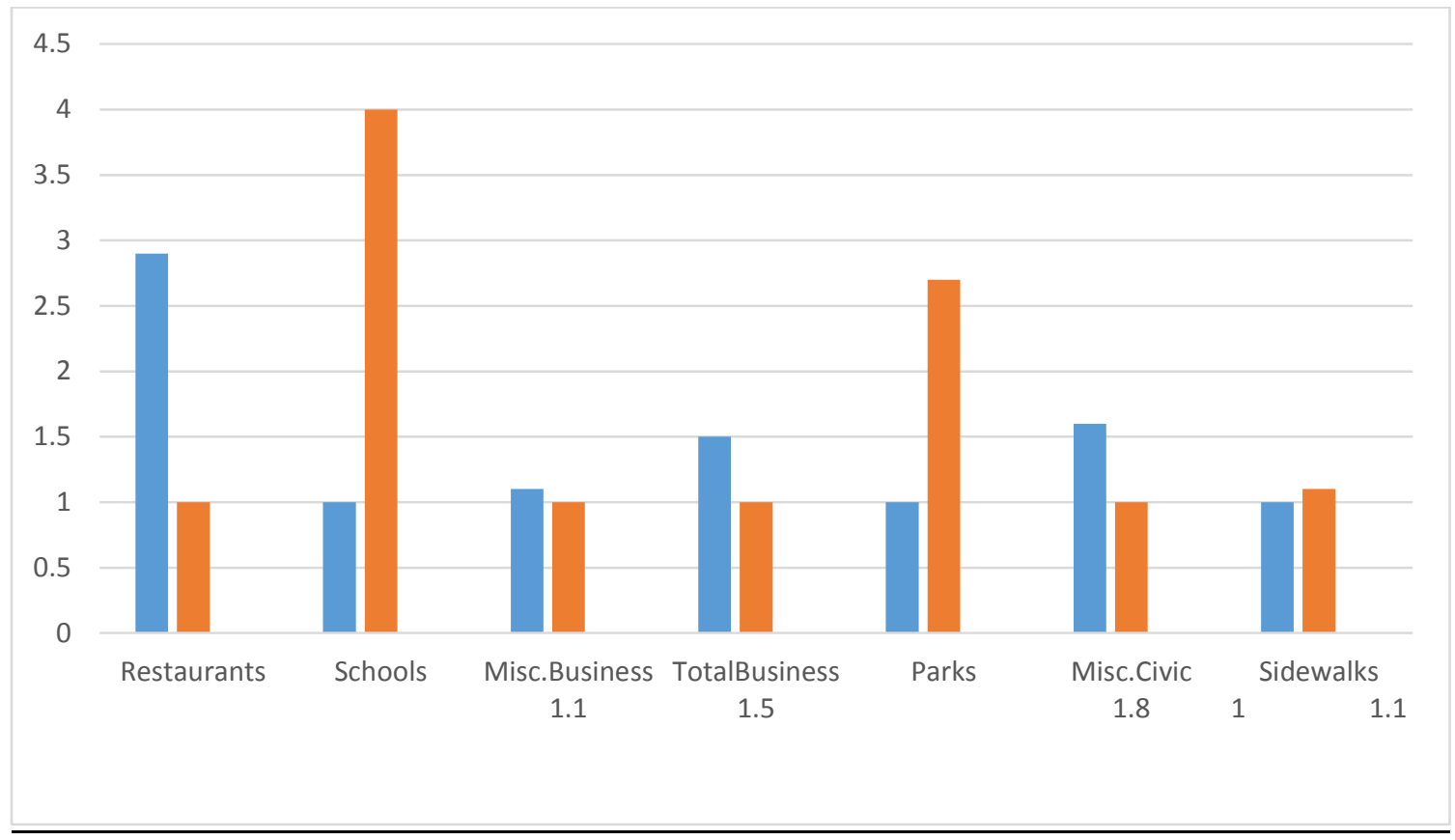

The medium importance indicators evaluated in this study cover issues such as recreation, as well as things which may have some relationship with necessity but have a less direct impact upon the daily needs of residents than the indicators of higher importance. These indicators can be further broken down into categories of housing indicators, employment indicators, and amenity-oriented indicators.

Thirty-eight percent of the homes for sale in Clifton are being sold at prices affordable to average income residents, while none are for Norton Commons. Interestingly, upon factoring in the 31 percent of homes for sale in Clifton that are affordable to below average income residents, and the remaining 31 percent that are only affordable to above average income residents, Clifton ends up having a nearly even distribution of housing prices. Around one-third are priced at below average, average, 
and above average price points, respectively. In a sense, it could be argued that Clifton is the paradigmatic mixed income community. This sort of income mixing is often favored by urban scholars, believing that such mixing promotes equitable spatial opportunity (Wilson, 1987 and 1996; Jargowski, 1997; Dreier, et al., 2014). Additionally, it is worth noting that a total of 69 percent of the houses for sale in Clifton can be described as affordable to either below average or average income residents. This data demonstrates the general level of affordability of houses in the neighborhood to the public at large. Norton Commons, conversely, has no houses for sale that are affordable to either average or below average income residents. This lack of accessibility is not uncommon for private New Urban communities, as Talen (2010) discovered that only 15 percent of private New Urban communities have a single home which is affordable to average income residents nationwide.

After accounting for the projected impact of Norton Commons' affordable housing project, Norton Commons outpaces Clifton in terms of rental units in the average income range, 38 percent to 33 percent. Even without factoring in the affordable housing project, Norton Commons matches Clifton in terms of rental units within the average income price point. These results are somewhat uncharted territory, in that prior research of private New Urban communities primarily focuses upon homes that are owned (Eppli and Tu, 1999; Talen, 2010), rather than rental units. However, these results are in contrast to Prater’s (2011) findings regarding rental units in Atlanta, which suggest a lack of affordability of New Urban rentals. Nonetheless, the data on New Urban rentals, nationally, is more limited than it is for owned New Urban homes. There are elements of these findings that deserve a critical look, but to some degree this begs for further 
research into rental prices for New Urban communities. If these findings mirror what might be found in other New Urban communities, it is possible that New Urban rental property may be somewhat more attainable, for the public-at-large, than homes for purchase.

While this is a worthwhile observation, it must be noted that Norton Commons' slight edge over Clifton in terms of rental units priced for average income residents is partially impacted by the fact that a high percentage of Clifton's rental units are affordable to below average income residents (67 percent). Only 33 percent of rental units remaining in Clifton are affordable to average income residents. Thus, Clifton outpaces Norton Commons in terms of total rental units affordable to either below average or average income residents. All 100 percent of Clifton's rental units meet this threshold, compared to 40 percent for Norton Commons. Nonetheless, the data does suggest that when compared to the possibility of home-ownership in the neighborhood, rental units in Norton Commons are available to a relatively larger pool of income groups.

In evaluating the workplaces that primarily provide skilled employment, ranging from air conditioning installation to medical care, Norton Commons, with 39, has more than Clifton, with 27. This distribution widens when considering that these worksites account for 64 percent of the sites of industry in Norton Commons, versus 33 percent for Clifton. A possible explanation for the strong frequency of such worksites in Norton Commons is that New Urbanism seeks to create communities where people can live where they work (Congress of New Urbanism, 2016). Given that price points for homes in Norton Commons likely were anticipated to be high, it is possible that the 
neighborhood felt it necessary to attract high-paid professionals in order to achieve this paradigm. From a consumer perspective, this could also be seen as responding to needs that are specific to an affluent customer base. For example, Norton Commons outnumbers Clifton in financial establishments, seven-to-two. However, it is important to note that this indicator is included as a social equity indicator of medium importance due to the possibility that skilled job opportunity will attract middle income workers. This corresponding relationship could potentially happen with such businesses, given the jobs for paralegals, receptionists, medical assistants, and other positions that might be available at such workplaces.

In terms of amenities, restaurants and parks largely represent entertainment or recreational possibilities and to some extent may also indicate the vibrancy of a community. Clifton has nearly three times the amount of restaurants as does Norton Commons, with 26 restaurants compared to Norton Commons' nine. Along with what this difference may suggest in terms of better options for consumer activity within the neighborhood, it is worth noting that this large number of restaurants is also a significant contributor to the neighborhood's total count of unskilled job facilities. Restaurants account for 26 of Clifton's 55 unskilled jobs facilities, or 47 percent. While parks do not necessarily help residents take care of their essential daily needs, it has long been argued that access to green space builds communities, for the greater social good (Olmstead, 1896). Norton Commons has an eight-to-three advantage over Clifton in terms of parks. Certainly, in terms of providing residents with this type of amenity, Norton Commons has exceeded Clifton. However, it is interesting to look at what some of the possible side effects of a potential over-indulgence in parks might be. Norton Commons boasts that, as 
a result of these eight parks, one-quarter of their land is green space (Norton Commons LLC, 2015). New Urbanism, in general, has a relatively lukewarm attitude about density (Fulton, 1996), which may in turn produce the opportunity for large amounts of green space. However, focusing on an abundance of green space rather than population density, which could be accomplished through building more homes on some of the green space, may potentially have a negative impact upon the amount of business that the neighborhood can support. This land use could contribute to deficits that may be seen in other areas, such as employment opportunity and consumer access to essential daily goods. Nonetheless, Norton Commons exceeds Clifton's capacity to provide the amenity of parks, but it is interesting to note the possible impact upon other amenities when there is too strong of a focus in a conflicting direction.

Amenities such as schools, community centers, and general civic facilities serve various public functions within a neighborhood. Norton Commons has a four-to-one advantage over Clifton in terms of schools. Three of Norton Commons' schools are private academies that charge tuition, while Clifton's one school only serves the blind population. The cost of Norton Commons' private schools, and the specialized nature of Clifton's school for the blind, make it difficult to conclude that any such schools are representative of the needs of the general public. Probably the most important fact, inside the numbers, is that Norton Commons has recently opened a public elementary school, which is less prohibitive in nature than the aforementioned schools. For this reason, even when parsing out the specifics, Norton Commons is likely stronger than Clifton at providing schooling options to a variety of residents. Putnam uses community centers as a proxy for social capital (Putnam, 2000). Clifton possessing a community center, while 
Norton Commons does not, likely reflects this principle. The Clifton Community Council does indeed use the community center as a forum for community action. Additionally, Clifton has nearly twice as many miscellaneous civic facilities as Norton Commons. Seven of these nine miscellaneous civic facilities are churches, whereas Norton Commons' five miscellaneous civic facilities range from a church, to a fire department, to an amphitheater, to a YMCA, to an arts academy. While there may be something to be said for the diversity of civic options in Norton Commons, there is also significance to the strength in numbers for Clifton in this category. While Clifton's bevy of churches may appear to indicate an over-emphasis upon religion in the neighborhood, it is important to note that churches have long been identified by scholars as potential springboards for community organization (Bailey Jr., 1974).

In terms of prevalence of sidewalks, Norton Commons and Clifton stack up nearly evenly. Norton Commons possesses sidewalks on 86 percent of the neighborhood's streets, compared to 83 percent for Clifton. While this advantage is slight, it is worth noting that in gathering this primary data, the portions of Clifton which did not have sidewalks were more problematic to walk on than those in Norton Commons, due to a higher volume of traffic. However, it is possible that Norton Commons could encounter similar issues on streets without sidewalks if the neighborhood grows. Neither neighborhood has any bike lanes on their roads, though Clifton does a have a bike path that cuts through the neighborhood, as part of the Louisville Loop bike path. This bike path is designed to give the city's residents easy routes to bicycle to and from various areas of Louisville (Louisville Metro Government, 2017). However, this does little to assist residents in riding a bicycle throughout the 
neighborhood. The lack of bike lanes is a concern shared by the creators of Clifton's new neighborhood plan, the Department of Urban and Public Affairs at the University of Louisville, citing the creation of bike lanes as a top need for Clifton (University of Louisville, 2016). Research on Norton Commons would obviously reveal the same conclusion about the lack of bike lanes. In total, it would be difficult to find a significant difference between the two neighborhoods in pedestrian and bicycle-friendliness.

Overall, in comparing the strength of each neighborhood regarding indicators of spatial social equity of medium-level importance, the results are mixed. After consolidating some categories which may contribute to redundant results, Clifton outperforms Norton Commons in six out of 11 categories, which suggests a fairly even performance between the neighborhoods. In terms of areas in which one neighborhood has a clear advantage over the other, Clifton appears to offer more restaurant choice and business in general, in addition to more sites for civic engagement, such as community centers and churches. Meanwhile, Norton Commons has a clear advantage in terms of parks, neighborhood schools, and job potential for skilled residents. 


\section{Low Importance Indicators}

Table 5.4- Results for Low Importance Indicators of Social Equity at the Neighborhood Level.

\begin{tabular}{|l|c|c|}
\hline \multicolumn{1}{|c|}{ Indicator } & Clifton & Norton Commons \\
\hline Bars & 4 & 2 \\
\hline $\begin{array}{l}\text { Proportion of } \\
\text { Amenities Located } \\
\text { within 500 feet of } \\
\text { Neighborhood Center }\end{array}$ & $31 \%$ & $80 \%$ \\
\hline $\begin{array}{l}\text { Percentage of Streets } \\
\text { with Automobile } \\
\text { Lanes }\end{array}$ & $17 \%$ & $7 \%$ \\
\hline
\end{tabular}

(Source: Appendix A) 
Figure 5.4- Neighborhood to Neighbood Ratio of Low Importance Indicators for Social Equity.

Blue-Clifton, Red- Norton Commons

*AmenCen refers to amenties located within 500 feet of the neighborhood center.

*CarLanes is a comparison of the percentage of streets with car lanes for each neighborhood, not a numeric count.

*For the purposes of this study, a lower number in the "CarLanes” category indicates a more favorable result.

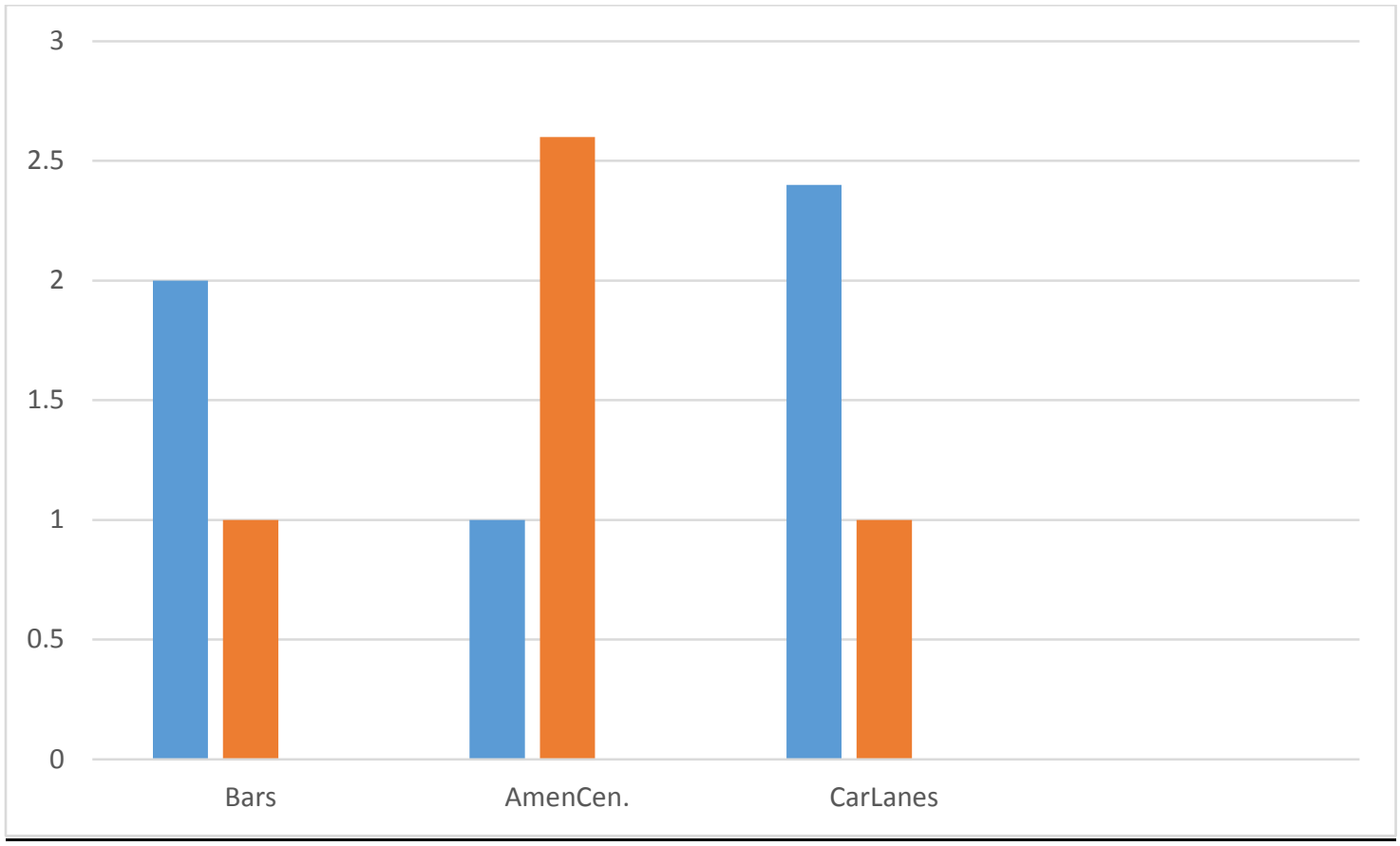

Low importance indicators may have a very limited impact upon the daily needs of residents compared to indicators denoted of higher importance. Clifton has four bars, compared to two in Norton Commons, suggesting that there may be more residents monitoring the streets late at night, in line with safety principles championed by Jane Jacobs (1961). The values of this theory have been adopted by the Ahwahnee Principles and are given some importance within this study, for whatever impact such dynamics might have. However, this indicator is not ranked with higher importance because it is difficult to tie this concept closely to the level of crime in the neighborhood, given its very anecdotal nature. Amenities in Norton Commons are over two-and-a-half times more likely to be located in the center of the neighborhood than is the case in Clifton. 
Given that both of these neighborhoods are already walkable in scale, center-orientation is not listed as a high-level priority. However, center-orientation provides general convenience for residents, and may be helpful to some residents with limited physical mobility. Clifton’s streets are nearly two-and-a-half times more likely than Norton Commons' streets to have an automobile lane. The relative prevalence of automobile lanes in Clifton would likely be seen as disadvantageous to the day-to-day lives of Clifton's pedestrians. This frequency is an indication of the degree to which residents encounter high speed traffic when walking through the neighborhood. While this disparity represents a meaningful advantage for Norton Commons, this indicator has been ranked as low importance. Given the presence of walk signals to aid residents in crossing many streets, and the absence of any significant issues regarding pedestrian casualties, the impact of this advantage on the daily lives of residents is negligible compared to other indicators.

While Clifton appears more likely to have activity on the street during late hours, Norton Commons appears to have a more convenient pedestrian design, and is also more likely to remove pedestrians from high-speed automobile traffic. This convenient, center-oriented design shows that some neighborhood benefits can be directly created by a design system, such as New Urbanism. However, the results for higher-ranking indicators of this study show that design alone is often not enough. Nonetheless, in total, it can be concluded that Norton Commons has somewhat of an advantage over Clifton in addressing these low importance indicators, though the results are somewhat mixed. 


\section{Industry Types by Neighborhood}

In this chapter, both from a consumer point-of-view and from an employment standpoint, details have been given about the establishments and organizations in Clifton and Norton Commons. But there is an additional layer to explore regarding the distribution of various business establishments and organizations in these neighborhoods: there are more formal and comprehensive ways of categorizing workplaces through the sociology of work, a subfield within sociology. Understanding these categorizations allows for a more comprehensive look at the types of work and industry that each of these two neighborhoods (and potentially grassroots revitalization efforts and New Urbanism, in general) might attract. Types of industry are thoroughly detailed in the work of Hodson and Sullivan (2006), dividing services into six categories: professional services, business services, producer services, personal services, distributive services, and social services. Table 5.50 provides definitions for each of these industry types, and Tables 5.51-5.52, as well as Figure 5.5, present the distribution of various industries within Clifton and Norton Commons. Following the presentation of this data, the remainder of this section analyzes what this distribution of industry means within the contexts of these neighborhoods and the larger paradigms that they represent. 
Table 5.50- The Six Types of Service Industries.

\begin{tabular}{|c|c|c|}
\hline Industry Type & Definition & $\begin{array}{c}\text { Examples of } \\
\text { Occupations within } \\
\text { Industry } \\
\end{array}$ \\
\hline Professional Services & $\begin{array}{l}\text { Provides knowledge-based } \\
\text { services for individuals or } \\
\text { firms who are clients. }\end{array}$ & $\begin{array}{l}\text { Doctors, Lawyers, } \\
\text { Counselors, Architects, etc. }\end{array}$ \\
\hline Business Services & $\begin{array}{l}\text { Assists individuals, firms, and } \\
\text { organizations in carrying out } \\
\text { their economic functions. }\end{array}$ & $\begin{array}{l}\text { Employees in advertising, } \\
\text { financial services, } \\
\text { accounting, real estate, } \\
\text { insurance, data-processing, } \\
\text { etc. }\end{array}$ \\
\hline Producer Services & $\begin{array}{l}\text { Helps other industries create } \\
\text { their products or services. }\end{array}$ & $\begin{array}{l}\text { Work in electricity, gas, } \\
\text { water, sanitation, garbage, } \\
\text { telecommunications, etc. }\end{array}$ \\
\hline Distributive Services & $\begin{array}{l}\text { Brings about the geographic } \\
\text { dispersion of goods. }\end{array}$ & $\begin{array}{l}\text { Warehousing, truck drivers, } \\
\text { retail workers, etc. }\end{array}$ \\
\hline Personal Services & $\begin{array}{l}\text { Delivers services directly to } \\
\text { the final consumer. }\end{array}$ & $\begin{array}{l}\text { Work in restaurants, hotels, } \\
\text { entertainment, tourism, repair } \\
\text { services, cosmetology, } \\
\text { cleaning services, etc. }\end{array}$ \\
\hline Social Services & $\begin{array}{l}\text { Frequently (but not always) } \\
\text { financed by the government } \\
\text { and benefit society as a } \\
\text { whole. }\end{array}$ & $\begin{array}{l}\text { Work in national security, } \\
\text { justice, postal services, } \\
\text { nursing homes, policing, etc. }\end{array}$ \\
\hline
\end{tabular}

*Producer services under Hodson and Sullivan's definition is quite different from advanced producer services discussed in global city literature (primarily Sassen, 2006). As the table indicates, this definition of producer services applies primarily to utilities, whereas "producer services" within the global city context refers to industries which subsist on information exchange (i.e. banking, law, insurance, etc.).

*In addition to the six types of services characterized by Hodson and Sullivan, I distinguish "educational services", "construction”, "government/administrative”, or "other". 
Table 5.51- Industry Types by Neighborhood: Clifton and Norton Commons.

\begin{tabular}{|c|c|c|}
\hline Industry Type & Clifton & $\begin{array}{c}\text { Norton } \\
\text { Commons } \\
\end{array}$ \\
\hline Professional Services & 4 & 15 \\
\hline Business Services & 2 & 9 \\
\hline Producer Services & 0 & 0 \\
\hline Distributive Services & 31 & 10 \\
\hline Personal Services & 44 & 19 \\
\hline Social Services & 1 & 1 \\
\hline Government/Administrative & 1 & 0 \\
\hline Construction & 5 & 1 \\
\hline Educational Services & 1 & 4 \\
\hline Other & 7 & 1 \\
\hline
\end{tabular}

(Source: Appendix A) 
Figure 5.5- Neighborhood-to-Neighborhood Ratio of Various Industry Types.

Blue- Clifton, Red- Norton Commons

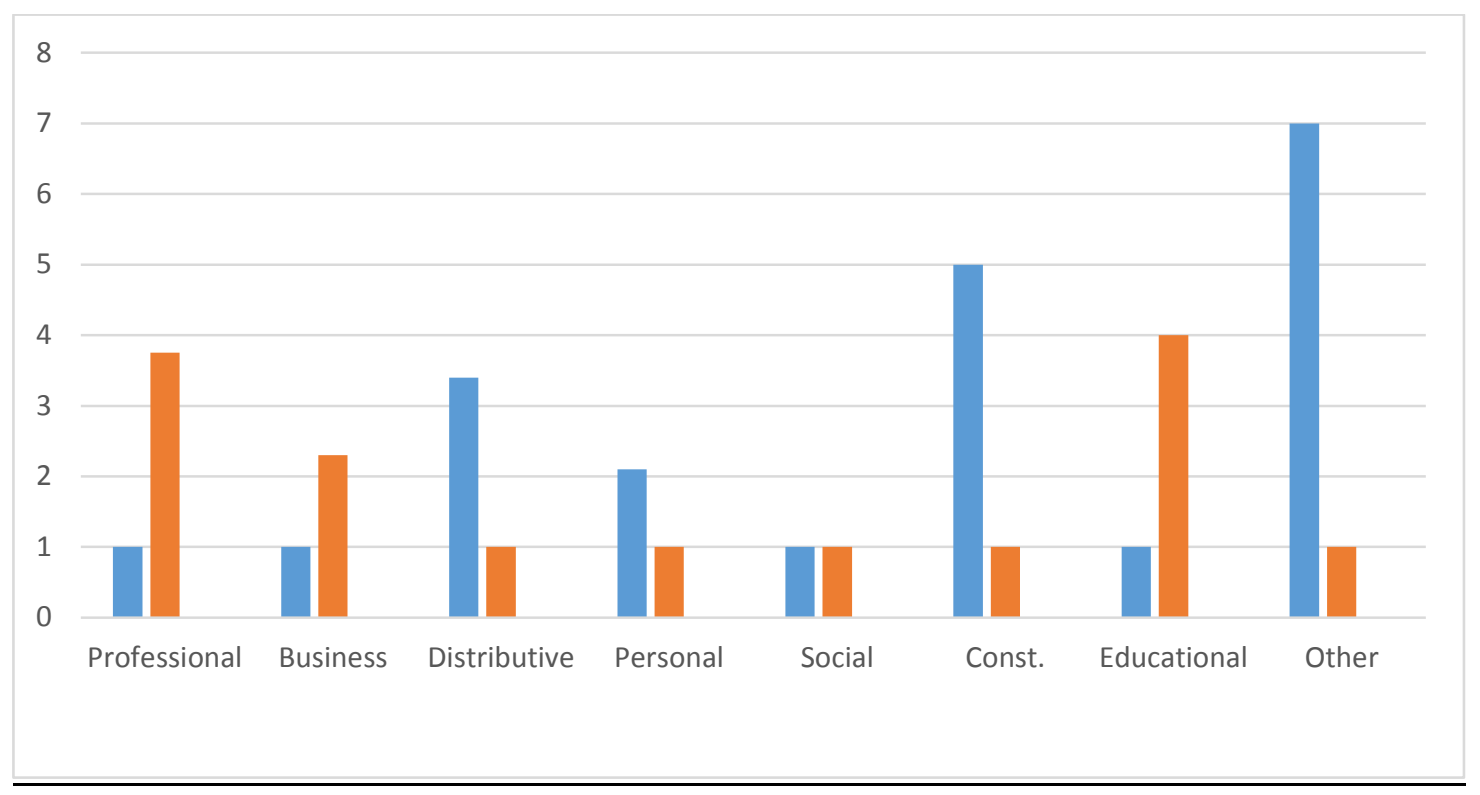

Table 5.52- Industry Types as a Percentage of Neighborhood's Total Industry.

\begin{tabular}{|c|c|c|}
\hline Industry & Clifton & $\begin{array}{c}\text { Norton } \\
\text { Commons }\end{array}$ \\
\hline Professional Services & $4 \%$ & $25 \%$ \\
\hline Business Services & $2 \%$ & $15 \%$ \\
\hline Producer Services & $0 \%$ & $0 \%$ \\
\hline Distributive Services & $32 \%$ & $17 \%$ \\
\hline Personal Services & $46 \%$ & $32 \%$ \\
\hline
\end{tabular}




\begin{tabular}{|l|c|c|}
\hline Social Services & $1 \%$ & $2 \%$ \\
\hline Government/Administrative & $1 \%$ & $0 \%$ \\
\hline Construction & $5 \%$ & $2 \%$ \\
\hline Educational Services & $1 \%$ & $7 \%$ \\
\hline Other & $7 \%$ & $2 \%$ \\
\hline
\end{tabular}

The vast majority of industry in Clifton, 78 percent, can be described as either distributive or personal services. Work within these two industry types includes retail, restaurants, hotels, entertainment, tourism, repair services, cosmetology, and cleaning services, among other types of business. These two industry types only make up 49 percent of the industry in Norton Commons. In terms of raw numbers, Clifton dwarfs Norton Commons by a count of 75 to 29 in terms of worksites that are defined as either distributive or personal services. It is evident how this gap has impacted the various social equity indicators within this study. Most unskilled job opportunities can be accounted for as either "distributive services" or "personal services”, and Clifton held a significant advantage over Norton Commons in this arena. Additionally, essential daily goods are obtained through distributive service industries. Thus, Clifton's previously discussed advantage in consumer goods access is consistent with outnumbering Norton Commons 31 to 10 in distributive service facilities. Finally, Clifton's significant advantage in restaurant choice, and its 44-to-19 advantage over Norton Commons in personal service industries, are highly intertwined. 
After personal services, at 32 percent, the most prevalent industry type in Norton Commons is professional services, at 25 percent. Following professional services, distributive services is slightly ahead of business services as the third most prevalent industry type in the neighborhood. With a combined 40 percent of industries in either professional or business services, a business establishment in Norton Commons is over six times more likely than a Clifton establishment to be in these categories, which combine to make up only 6 percent of industry in Clifton. Even with a smaller amount of business overall, Norton Commons still has four times the total number of professional and business service establishments as Clifton, outnumbering Clifton 24 to 6 in these categories. Work in these industries include doctors, lawyers, architects, accountants, realtors, and other positions. Given the level of training involved in this work, and the potential pay scale, these industries produce primarily skilled employment, and likely more affluent workers than many other industries.

The relative strength of Norton Commons, compared to Clifton, in producing skilled worksites is reflected in the prevalence of professional and business service industries in Norton Commons. Additionally, with a relatively large portion of industry in Norton Commons gravitating towards this type of work, a potential negative may be the neighborhood placing too much focus upon attracting high-end employment, at the expense of attracting unskilled job opportunity. An increase in unskilled labor facilities may cater to the more diverse socioeconomic base in which New Urbanism professes to be interested. Ultimately, the prevalence of professional and business service industries in the neighborhood may possibly be the result of Norton Commons' response to the "live where you work" principle championed within New Urbanism (Congress for the 
New Urbanism, 2016). To apply this principle in Norton Commons, the neighborhood would need to attract high-end employment to accompany the high real estate prices. While cataloging the types of industry within these neighborhoods is primarily for descriptive statistical purposes, it is apparent how the various industry types that dominate in Clifton and Norton Commons have had a significant impact upon the results for the high importance indicators for social equity within this study.

\section{Comprehensive Analysis of Social Equity Indicators at the Neighborhood Level for Clifton and Norton Commons}

As it relates to the more highly-ranked social equity indicators, those labelled as “central importance” or "high importance”, Clifton has a clear advantage over Norton Commons. Clifton's housing options are spread nearly evenly across income groups, including "below average income”. Norton Commons, conversely, will offer only a small contingency of below average income housing, upon the completion of its affordable housing project. Meanwhile, they also offer no houses for sale that are affordable to below average income residents, with the majority of houses for sale only affordable to extremely affluent residents. It is significantly more likely that Clifton residents can find workplaces that cater to unskilled employment, as well as access daily goods at grocery and convenience stores, than is the case for Norton Commons. Clifton holds an equally strong advantage in terms of accessing bus stops to travel throughout Jefferson County. Additionally, descriptive statistics highlighting the tendency of Clifton industry towards distributive and personal services, compared to Norton Commons' tendency towards professional and business services, speaks to how industry distribution 
has impacted the presence of unskilled job opportunity and access to essential daily goods in each neighborhood.

Concerning the lower-ranked social equity indicators, those labelled as "medium importance" or "low importance", Clifton and Norton Commons have performed nearly evenly. Clifton performed more strongly than Norton Commons in such areas as restaurant options, total business, civic facilities, and late-night establishments. Norton Commons performed more strongly than Clifton in areas such as green space, neighborhood schooling options, skilled job opportunities, center orientation, and protection from automobile traffic. Norton Commons' relatively strong performance among the lower-ranked indicators perhaps indicates some of what can be accomplished by design alone. The Ahwahnee Principles dictate that a New Urban community be center-oriented and provide ample green space, and Norton Commons appears to have met those design principles. New Urbanism frequently pushes the idea of "live where you work" (Congress for the New Urbanism, 2016), and it is possible that Norton Commons sought out many high-end professional and business service industries to comport with what has proven to be an affluent residential base. Of course, further empirical research could possibly demonstrate that these businesses were opened by the residents after they moved to Norton Commons. Nonetheless, design has potentially allowed Norton Commons to perform adequately in these portions of the comparison. It is perhaps some of the higher-ranked indicators, regarding issues such as affordable housing, unskilled jobs, and access to essential daily goods, which cannot be accomplished by neighborhood design alone. These indicators are potentially more influenced by things such as the market; location within the metropolitan area; and 
having a dense, thriving population base. If it is the case that New Urban design can accomplish lower- priority social goals, but not ones of greater importance, such a finding would be consistent with Talen’s (2010) argument that New Urbanism cannot accomplish its goals relying entirely upon design.

On the whole, it can be concluded that Clifton has performed more strongly than Norton Commons regarding the indicators of social equity for the neighborhood portion of the comparison. While Norton Commons held its own in terms of lower-ranked indicators, Clifton's superior performance regarding the higher-ranked indicators gives their neighborhood the advantage within the comparison. Clifton not only outperforms Norton Commons in more categories, but also outperforms Norton Commons in areas of greater importance. The next chapter, Chapter VI, presents the findings regarding the social equity indicators for the nearby areas of Clifton and Norton Commons, as well as the corresponding analysis. 


\section{CHAPTER VI}

\section{COMPARISON OF SOCIAL EQUITY INDICATORS FOR THE RESPECTIVE NEARBY AREAS OF CLIFTON AND NORTON COMMONS}

In a similar fashion as Chapter V's neighborhood-level findings, this chapter presents the results for the indicators of social equity for the nearby areas of Clifton (Clifton Heights and Crescent Hill) and Norton Commons (Wolf Trace Subdivision and suburban shopping to the south). Absent from the results are findings on rental units, due to limited data, and findings on center-orientation, due to inapplicability. In addition to presenting these results, analysis will be provided throughout the chapter, as well as comprehensively at the chapter's end, to detail what these findings mean within the context of social equity, as well as grassroots revitalization and New Urbanism.

\section{Central Importance Indicators}

Table 6.1- Results for Central Importance Indicators of Social Equity for the Nearby Areas of Clifton and Norton Commons.

\begin{tabular}{|l|c|c|}
\hline \multicolumn{1}{|c|}{ Indicator } & Clifton Nearby Area & $\begin{array}{c}\text { Norton Commons } \\
\text { Nearby Area }\end{array}$ \\
\hline $\begin{array}{l}\text { General Percentage of } \\
\text { Houses Affordable to } \\
\text { Below Average } \\
\text { Income Residents }\end{array}$ & $20 \%$ & $0 \%$ \\
\hline $\begin{array}{l}\text { Percentage of Two } \\
\text { Bedroom Houses } \\
\text { Affordable to Below } \\
\text { Average Income } \\
\text { Residents }\end{array}$ & $0 \%$ & $0 \%$ \\
\hline
\end{tabular}




\begin{tabular}{|l|c|c|}
\hline $\begin{array}{l}\text { Percentage of Three } \\
\text { Bedroom Houses } \\
\text { Affordable to Below } \\
\text { Average Income } \\
\text { Residents }\end{array}$ & $0 \%$ & $0 \%$ \\
\hline $\begin{array}{l}\text { Percentage of Houses } \\
\text { Affordable to only } \\
\text { Extremely Affluent } \\
\text { Residents }\end{array}$ & $0 \%$ & $0 \%$ \\
\hline
\end{tabular}

(Sources: zillow.com and trulia.com—retrieved September 20, 2016)

By and large, there is not much of a presence of houses for sale that are affordable to below average income residents in the areas neighboring Clifton or Norton Commons. The extent to which it is available outside of Clifton consists of only very small housing, as in less than two bedrooms. The reason for this lack of low-income housing could relate to a smaller sample size, given the smaller area available for study. Additionally, with the area near Norton Commons, it has been established that Prospect is one of the most affluent communities in Kentucky. Thus, it is unsurprising that Norton Commons' nearby areas would not produce much in the way of affordable housing. On the whole, the areas near Clifton hold a modest edge in terms of providing affordable housing, but in neither case are there strong indications of affordable housing options. 


\section{High Importance Indicators}

Table 6.2- Results for High Importance Indicators of Social Equity for the Nearby Areas of Clifton and Norton Commons.

\begin{tabular}{|l|c|c|}
\hline \multicolumn{1}{|c|}{ Indicator } & Clifton Nearby Area & $\begin{array}{c}\text { Norton Commons } \\
\text { Nearby Area }\end{array}$ \\
\hline Grocery Stores & 1 & 0 \\
\hline $\begin{array}{l}\text { Convenient/Drug } \\
\text { Stores }\end{array}$ & 0 & 3 \\
\hline Clothing Stores & 2 & 10 \\
\hline $\begin{array}{l}\text { Potential Small } \\
\text { Employment }\end{array}$ & 34 & \\
$\begin{array}{l}\text { Facilities for } \\
\text { Unskilled Labor }\end{array}$ & & 1 \\
\hline $\begin{array}{l}\text { Potential } \\
\text { Medium-Sized } \\
\text { Employment }\end{array}$ & 0 & \\
\hline $\begin{array}{l}\text { Facilities for } \\
\text { Unskilled Labor }\end{array}$ & & \\
\hline Bus Stops & & 1 \\
\hline Libraries & & 0 \\
\hline
\end{tabular}

(Source: Appendix A) 
Figure 6.2- Ratio of Select High Importance Indicators of Social Equity for the Nearby Areas of Clifton and Norton Commons.

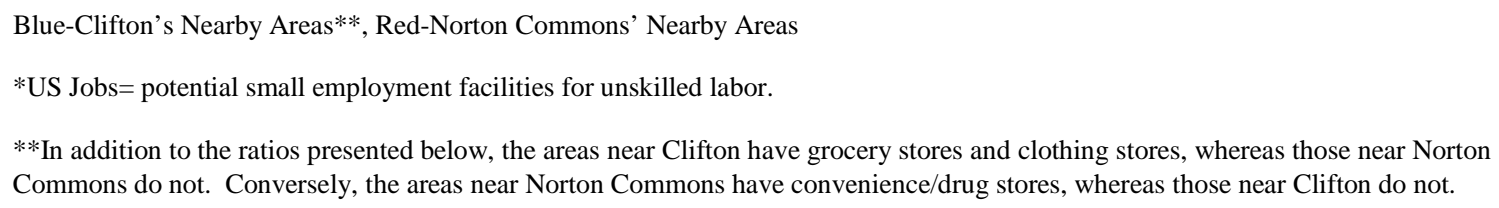

**In addition to the ratios presented below, the areas near Clifton have grocery stores and clothing stores, whereas those near Norton Commons do not. Conversely, the areas near Norton Commons have convenience/drug stores, whereas those near Clifton do not.

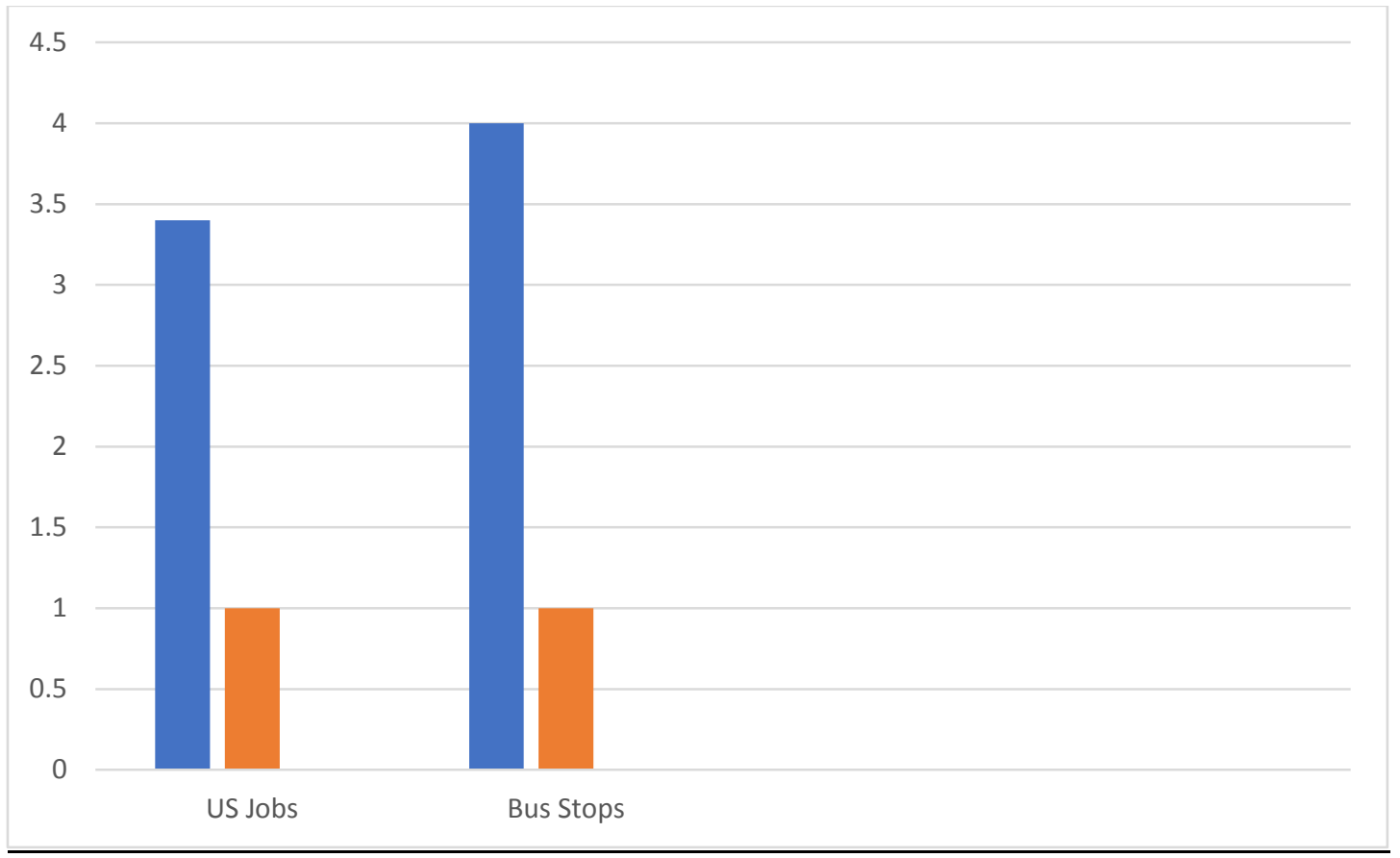

In evaluating high importance social equity indicators for the areas near Clifton and Norton Commons, results are somewhat mixed as it relates to access to daily goods. The areas near Clifton have a grocery store, whereas the areas near Norton Commons do not. However, there is a three-to-nothing advantage for the areas near Norton Commons over those near Clifton in terms of convenience/drug stores. Regarding clothing stores, the areas near Clifton have two, whereas those near Norton Commons have none. Perhaps even more encouraging, as it relates to access to daily goods, is the fact that these clothing stores are both consignment stores, suggesting they may potentially be affordable. 
In terms of unskilled labor opportunity, the areas near Clifton have over triple the facilities with such potential as the areas near Norton Commons, by a count of 34 to 10 . This difference may be partially explained by the fact that the area near Norton Commons is partially comprised of a single-use suburban subdivision, consistent with trends that have long been observed regarding private New Urbanism (Fulton, 1996; Eppli and Tu, 1999). The prevalence of unskilled labor facilities potentially further enhances the ability of a Clifton resident to walk to an unskilled job, with the areas nearby adding additional opportunity to that which already exists within the boundaries of Clifton. Regarding bus stops, the areas near Clifton outnumber the areas near Norton Commons four to one. This difference is potentially a result of the greater density of Clifton's nearby urban areas being more in alignment with the needs of efficient public transit than those near Norton Commons. Not only does this further bolster the proliferation of bus stops within Clifton and its general area, but the count of one bus stop outside of Norton Commons accounts for the only public transit access in the entire area of Norton Commons and its periphery.

The surrounding areas for each neighborhood are lacking libraries and potential medium-sized unskilled job facilities. However, there has been no occurrence of either of these indicators throughout this study, so the implications of this dearth of libraries may be somewhat limited. Across the high importance social equity indicators as a whole, the areas near Clifton have solidly outperformed those near Norton Commons. While the results regarding access to daily goods are mixed, the performance of the areas near Clifton in terms of unskilled job opportunity and transit access give these areas a clear advantage over those near Norton Commons. 


\section{Medium Importance Indicators}

Table 6.3- Results for Medium Importance Indicators of Social Equity for the Nearby Areas of Clifton and Norton Commons.

\begin{tabular}{|c|c|c|}
\hline Indicator & Clifton's Nearby Area & Norton Commons' Nearby Area \\
\hline Restaurants & 10 & 3 \\
\hline Schools & 1 & 0 \\
\hline $\begin{array}{l}\text { Miscellaneous } \\
\text { Business } \\
\text { Establishments }\end{array}$ & 31 & 17 \\
\hline $\begin{array}{l}\text { Total Business } \\
\text { Establishments }\end{array}$ & 44 & 23 \\
\hline $\begin{array}{l}\text { Percentage of Houses } \\
\text { in Middle Income } \\
\text { Range }\end{array}$ & $60 \%$ & $0 \%$ \\
\hline $\begin{array}{l}\text { Percentage of Houses } \\
\text { Affordable to Middle } \\
\text { Income Residents and } \\
\text { Below }\end{array}$ & $80 \%$ & $0 \%$ \\
\hline $\begin{array}{l}\text { Potential Small } \\
\text { Employment Facilities } \\
\text { for Skilled } \\
\text { Employment Only }\end{array}$ & 17 & 14 \\
\hline $\begin{array}{l}\text { Potential Medium- } \\
\text { Sized Employment } \\
\text { Facilities for Skilled } \\
\text { Employment Only }\end{array}$ & 0 & 1 \\
\hline Parks & 0 & 0 \\
\hline Misc. Civic Facilities & 3 & 2 \\
\hline Community Centers & 0 & 0 \\
\hline
\end{tabular}




\begin{tabular}{|l|c|c|}
\hline $\begin{array}{l}\text { Percentage of Streets } \\
\text { with Sidewalks }\end{array}$ & $58 \%$ & $65 \%$ \\
\hline $\begin{array}{l}\text { Percentage of Streets } \\
\text { with Bike Lanes }\end{array}$ & $0 \%$ & $0 \%$ \\
\hline
\end{tabular}

(Source: Primary Data Log/Appendix A; zillow.com and trulia.com—retrieved September 20, 2016) 
Figure 6.30- Ratio of Select Medium Importance Employment-Oriented Indicators of Social Equity for the Nearby Areas of Clifton and Norton Commons.

Blue- Clifton’s Nearby Areas**, Red- Norton Commons’ Nearby Areas

*SkillJobs refers to potential small employment facilities for skilled jobs only.

**In addition to small skilled job facilities, Norton Commons’ nearby areas possess a medium-sized employment facility for skilled jobs only, whereas Clifton's nearby areas do not.

*Graph not to scale

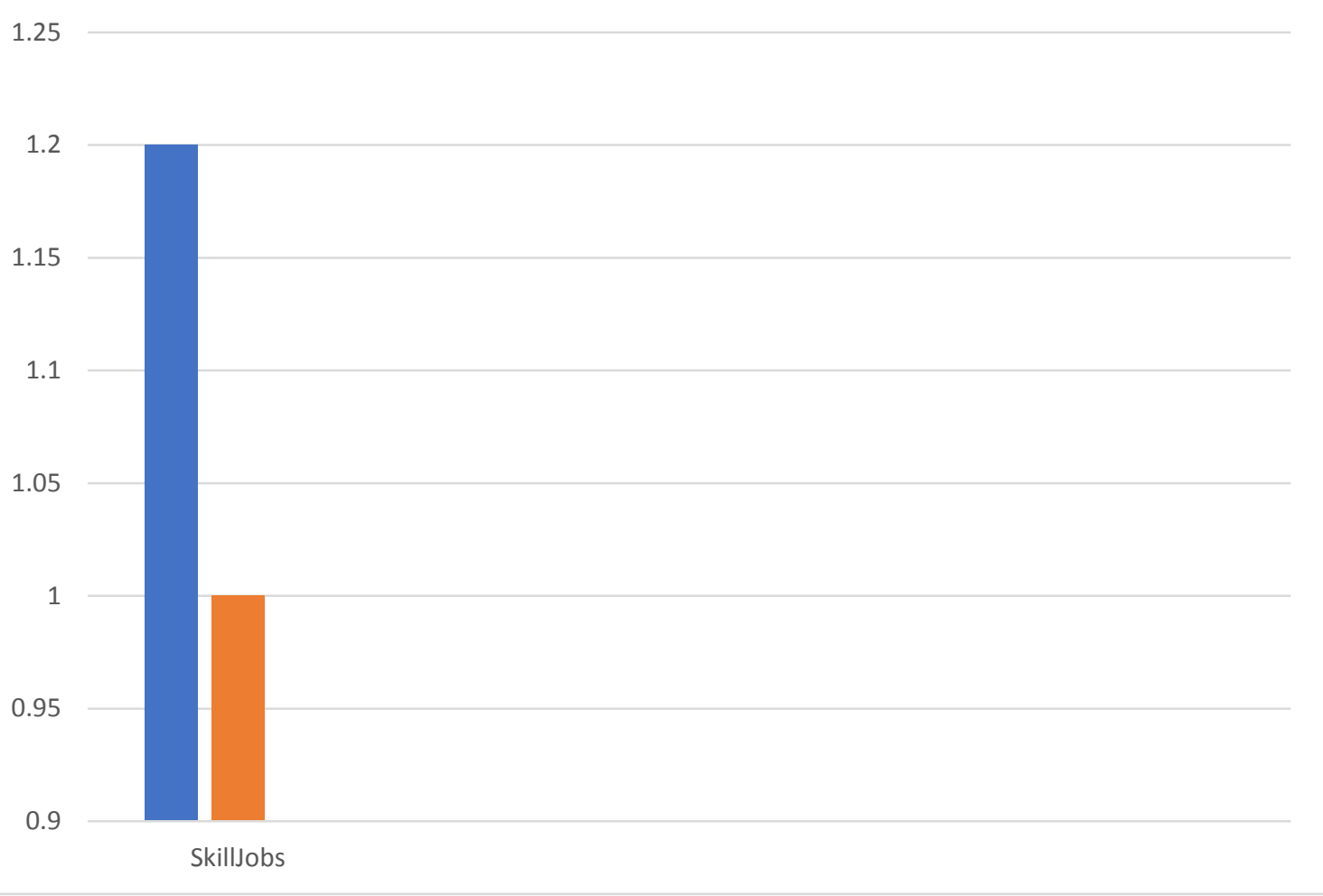


Figure 6.31- Ratio of Select Medium Importance Amenity-Oriented Indicators of Social Equity for the Nearby Areas of Clifton and Norton Commons.

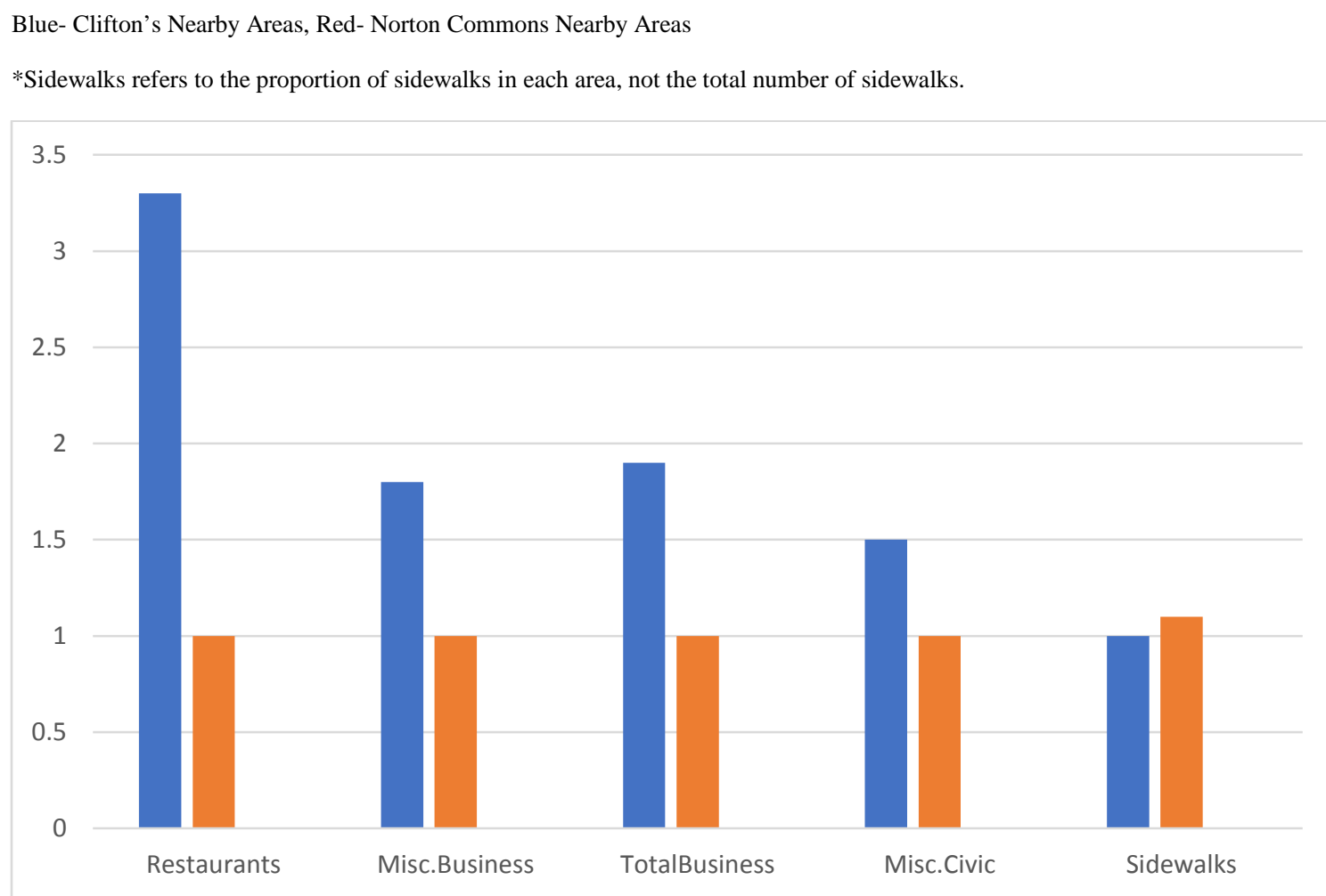

As it relates to medium importance housing-oriented indicators, the areas near Clifton perform more strongly than those near Norton Commons. Sixty percent of the houses for sale in the areas near Clifton are affordable to average income residents. Eighty percent of houses for sale in this area are affordable to either average or below average income residents. The areas near Norton Commons, meanwhile, do not have a single unit for sale that is affordable to average or below average income residents. The poor performance with these housing indicators for Norton Commons’ nearby areas could relate to Trudeau and Kaplan’s (2015) findings that housing in New Urban communities is priced similarly to housing within four miles of the NU community in question. However, this portion of the dissertation is evaluating a much smaller radius 
than their study. But it should be noted that Trudeau and Kaplan were presenting this information as an argument for the affordability of New Urban housing. In contrast, the findings of this section potentially suggest that their findings could mean that New Urban communities are typically located in expensive areas, and that New Urban communities are expensive, as well. The importance of this finding within this study, as it relates to social equity, is that it highlights how far the areas near Norton Commons are from being affordable. Thus, it is unlikely that there are low-income/low-mobility residents in the areas near Norton Commons who would benefit from its amenities.

The total count of potential small business establishments for skilled labor is higher, by a count of 17 to 14, for the nearby areas of Clifton than the nearby areas of Norton Commons. However, the areas near Clifton have more small potential employment facilities in general. Thus, the proportion of skilled job facilities among the employment facilities in Norton Commons’ nearby areas is 58 percent, versus 33 percent for the areas near Clifton. This disparity would indicate that the small business establishments near Norton Commons have a greater tendency of being geared towards skilled work. Nonetheless, the raw count would suggest that there are more total facilities where one could find skilled work in the areas outside of Clifton. Potential explanations for this are that Norton Commons' development in a less dense, suburban area, as is often the case with New Urban communities, results in fewer total businesses nearby. In some cases, the implication could be that even area business types that might exist in higher proportion, still will not match the presence of such businesses of areas that are denser.

The area near Norton Commons possesses the lone medium-sized employment facility in these neighborhoods or their surrounding areas-- Norton Brownsboro Hospital. 
This facility is geared towards skilled employment. The hospital is part of the Norton Healthcare system based in Louisville, with five hospitals, dozens of smaller facilities, and approximately 12,000 total employees. The development of Norton Commons and Norton Brownsboro Hospital in close proximity of each other is certainly not a coincidence. Both spring from the prominent Norton family of Louisville (Norton Commons LLC, 2016). Certainly, it is reasonable to argue that possessing a skilled employment facility allows Norton Commons to counteract the modest advantage that the nearby areas of Clifton have in terms of small employment facilities for skilled labor. It is possible that the large amount of affluent housing in both Norton Commons and its surrounding areas is to house the significant number of well-paid employees which Norton Brownsboro Hospital might employ. It is, however, not clear that the existence of this hospital near Norton Commons is part of any larger phenomenon that can be related to New Urbanism in general. Nonetheless, within this comparison, the nearby areas of Norton Commons likely offers more opportunity for skilled employment than the areas near Clifton, as a result of this hospital. Combined with the advantage noted in Chapter V that Norton Commons, itself, has in terms of skilled employment this nearby area further bolsters the presence of skilled employment opportunity for the area as whole.

As it relates to recreational amenities, while none of the nearby areas have a park, the nearby areas of Clifton have over three times as many restaurant options as the nearby areas of Norton Commons. This disparity is, again, likely a function of the increased business presence that can occur in a dense urban area versus less dense, single-use suburban areas. The area outside of Clifton has a middle school, whereas the area outside of Norton Commons does not have a school. This middle school likely makes up for 
some of the deficiency in schools which Clifton exhibited in the neighborhood portion of the study. Clifton's nearby areas outnumber those outside of Norton Commons in terms of miscellaneous civic facilities three to two. Subtracting the fire department and funeral home service outside of Clifton, as well as the cemetery outside of Norton Commons, this data amounts to each neighborhood having a church in its nearby areas. Thus, the nearby areas have done little to alter, either positively or negatively, the potential advantage in community involvement from an abundance of churches that was noted for Clifton in Chapter V. While neither neighborhood periphery has a bike lane, Norton Commons’ nearby areas have a 65 percent to 58 percent advantage in terms of the proportion of streets with sidewalks over Clifton's nearby areas. This finding represents somewhat of a statistical oddity in comparing single-use suburban areas to urban areas (Leyden, 2003). Nonetheless, Norton Commons' nearby areas have a modest advantage in terms of this indicator. In terms of medium importance amenities, the sizeable advantage in terms of restaurants and the presence of a school in Clifton's nearby areas likely outweighs the impact of Norton Commons’ nearby areas’ modest advantage in sidewalk frequency.

Overall, relating to social equity indicators of medium importance, the nearby areas of Clifton have a sizeable advantage in middle-income housing and restaurant options, and have a school. Norton Commons' nearby areas possess a much larger potential for employment of skilled labor, with the presence of Norton Brownsboro hospital. Overall, whatever attraction of middle class residents the hospital may bring is somewhat negated by the limited middle-income housing options in Norton Commons and its surrounding areas. The 2009 opening of the hospital post-dates the 2004 opening of Norton Commons (Norton Commons LLC, 2016), so it is possible that it was created 
to provide high-income jobs for already-existing Norton Commons residents. The availability of middle-income housing near Clifton may do more to attract middle-income residents, regardless of neighborhood job possibility, as middle-income residents are more mobile than low-income residents (Skoba and Goetz, 2013). This advantage, in addition to the area's advantage in restaurants and schooling, likely means that the areas near Clifton are doing more than the nearby areas of Norton Commons to contribute to spatial social equity, in terms of medium importance indicators.

\section{Low Importance Indicators}

Table 6.4- Results for Central Importance Indicators of Social Equity for the Nearby Areas of Clifton and Norton Commons.

\begin{tabular}{|l|c|c|}
\hline \multicolumn{1}{|c|}{ Indicator } & \multicolumn{1}{c|}{$\begin{array}{c}\text { Clifton's Nearby } \\
\text { Area }\end{array}$} & $\begin{array}{c}\text { Norton Commons' } \\
\text { Nearby Area }\end{array}$ \\
\hline Bars & 1 & 0 \\
\hline $\begin{array}{l}\text { Percentage of Streets } \\
\text { with Automobile } \\
\text { Lanes }\end{array}$ & $21 \%$ & $35 \%$ \\
\hline
\end{tabular}

(Source: Appendix A) 
Figure 6.4- Ratio of Automobile Lane Frequency for Nearby Areas of Clifton and Norton Commons.

Blue- Clifton’s Nearby Areas, Red- Norton Commons’ Nearby Areas

*CarLanes refers to the percentage of streets with automobile lanes, not the total number of streets with automobile lanes.

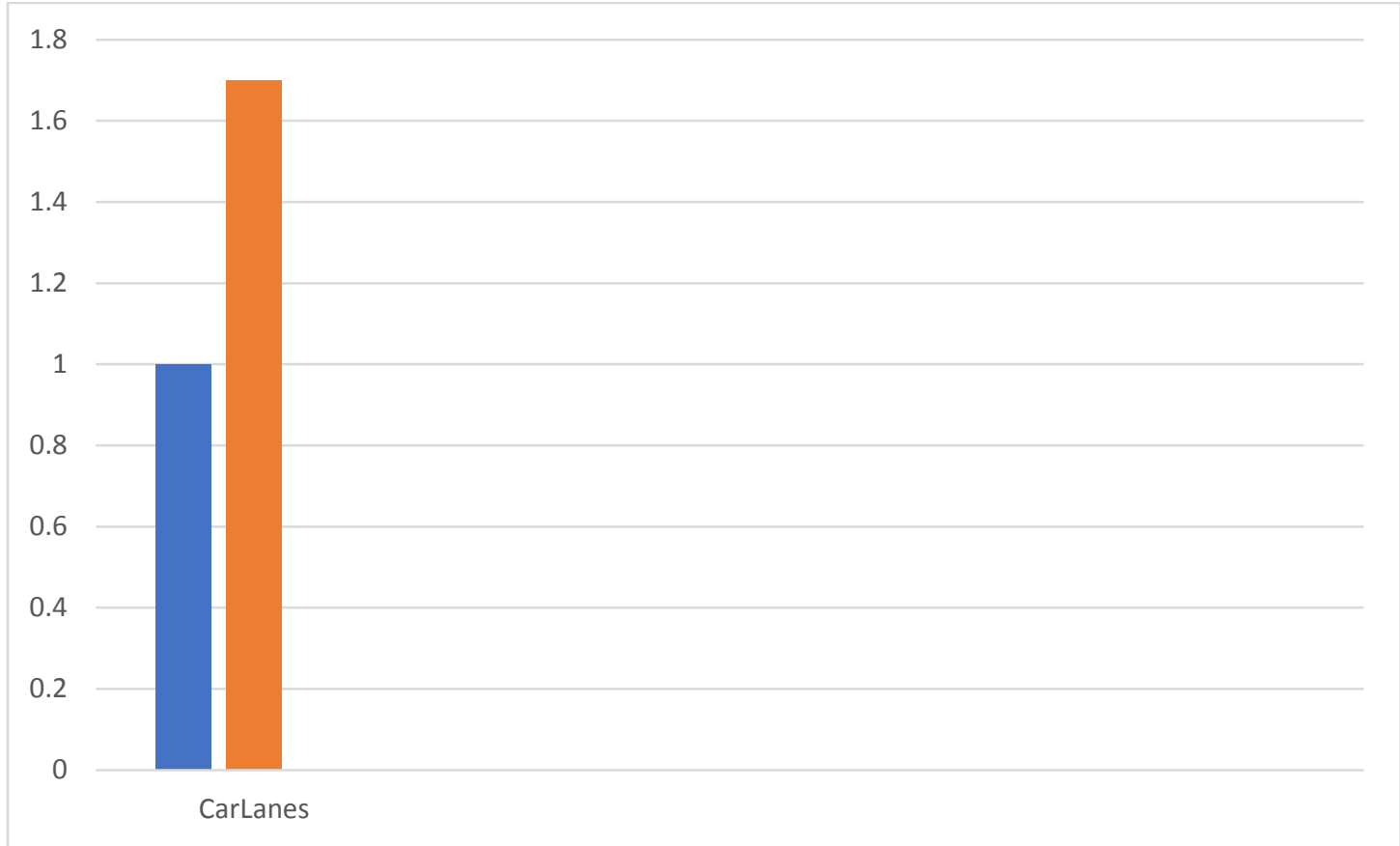

As it relates to bars, the nearby areas of Clifton have a bar, whereas the nearby areas of Norton Commons do not. Recalling in Chapter V that Clifton possesses more bars than Norton Commons, this additional bar further pads the advantage that the general area of Clifton has over the general area of Norton Commons, in terms of this amenity. As was discussed in Chapter V, the resulting implication is that there is likely more activity on the street late at night in the Clifton area than the Norton Commons area, which in some urban circles this suggests better citizen surveillance, and perhaps latenight safety (Jacobs, 1961). Again, this relationship is tenuous, which is why this Ahwahnee Principle-based indicator is categorized as being of low importance. 
Nonetheless, the areas outside of Clifton likely have moderately less isolated streets late at night than the areas outside of Norton Commons.

Clifton's nearby areas also have a lower frequency of automobile lanes on their streets than Norton Commons' nearby areas, by a count of 21 percent to 35 percent. Thus, pedestrians will have to deal with less high-speed traffic. Thus, residents walking from these nearby areas to Clifton, or vice versa, may have a somewhat safer walk than would be the case for residents of Norton Commons and its surrounding areas. This indicator is regarded as low importance because this study does not contend that pedestrians walking under conditions that are less pedestrian-friendly presents any imminent doom. While it is preferable for conditions to be safe, tangible, direct neighborhood benefits have been prioritized over this indicator. The moderate advantage of Clifton's nearby areas over those of Norton Commons in terms of bars and automobile lane-free streets indicates that Clifton's nearby areas perform more strongly in terms of these low importance indicators of social equity.

\section{Industry Types by Neighborhood}

Table 6.50- Industry Types for Nearby Areas of Clifton and Norton Commons.

\begin{tabular}{|l|c|c|}
\hline \multicolumn{1}{|c|}{ Industry Type } & Clifton's Nearby Area & $\begin{array}{c}\text { Norton Commons' } \\
\text { Nearby Area }\end{array}$ \\
\hline Professional Services & 3 & 8 \\
\hline Business Services & 2 & 2 \\
\hline Producer Services & 0 & 0 \\
\hline
\end{tabular}




\begin{tabular}{|l|c|c|}
\hline Distributive Services & 13 & 5 \\
\hline Personal Services & 31 & 11 \\
\hline Social Services & 3 & 0 \\
\hline Government/Administrative & 0 & 0 \\
\hline Construction & 0 & 0 \\
\hline Educational Services & 1 & 0 \\
\hline Other & 1 & 1 \\
\hline
\end{tabular}

(Source: Appendix A) 
Figure 6.5- Ratio of Various Industry Types for Nearby Areas of Clifton and Norton Commons.

Blue-Clifton’s Nearby Areas*, Red- Norton Commons’ Nearby Area

*In addition to the industry type comparisons listed below, Clifton's nearby areas have social and educational service industries, whereas the nearby areas of Norton Commons do not.

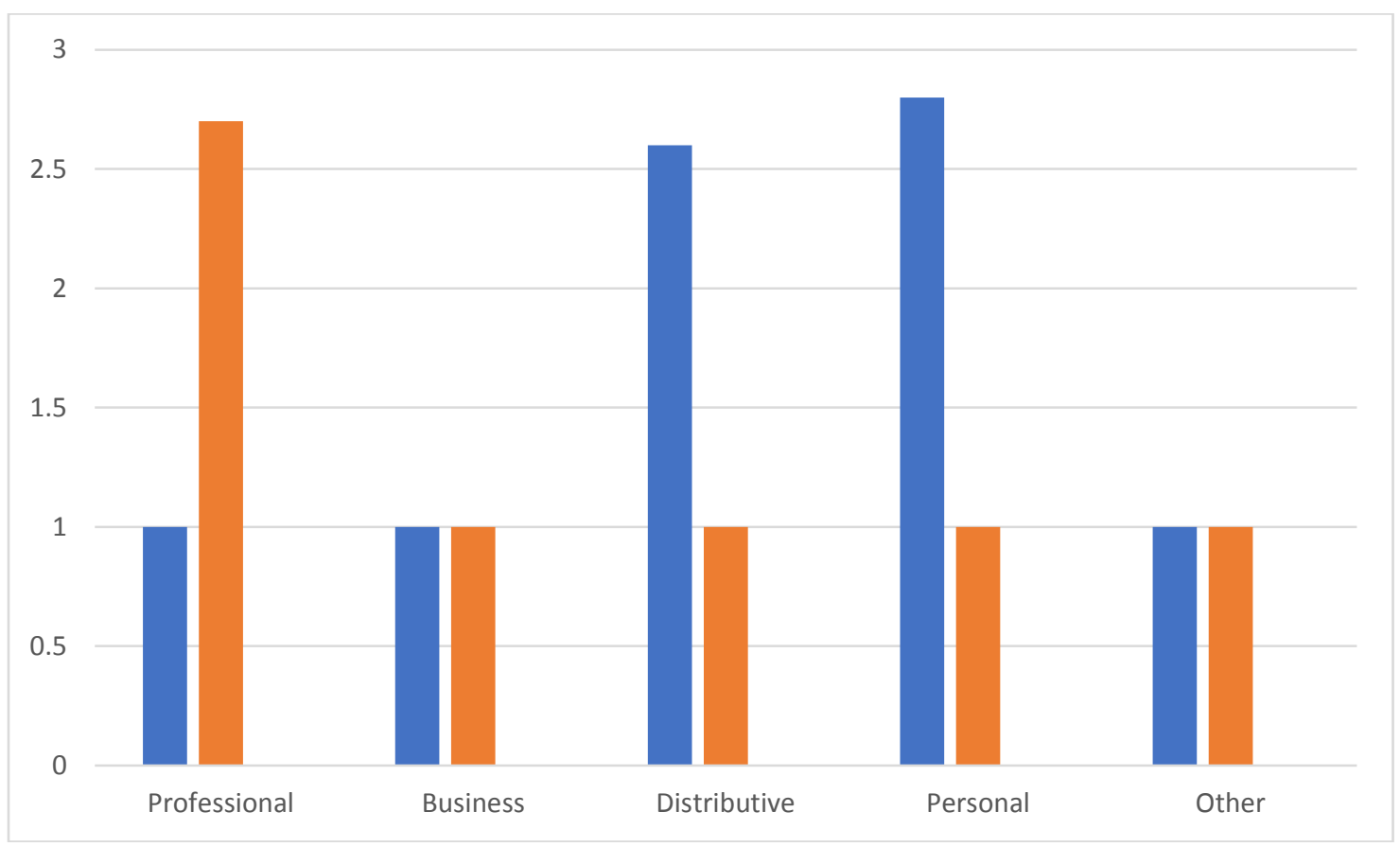

Table 6.51- Industry Types as a Percentage of Total Industry for Nearby Areas of Clifton and Norton Commons.

\begin{tabular}{|l|c|c|}
\hline \multicolumn{1}{|c|}{ Industry } & Clifton's Nearby Area & $\begin{array}{c}\text { Norton Commons' } \\
\text { Nearby Area }\end{array}$ \\
\hline Professional Services & $6 \%$ & $30 \%$ \\
\hline Business Services & $4 \%$ & $7 \%$ \\
\hline Producer Services & $0 \%$ & $0 \%$ \\
\hline Distributive Services & $24 \%$ & $19 \%$ \\
\hline
\end{tabular}




\begin{tabular}{|l|c|c|}
\hline Personal Services & $56 \%$ & $41 \%$ \\
\hline Social Services & $6 \%$ & $0 \%$ \\
\hline Government/Administrative & $0 \%$ & $0 \%$ \\
\hline Construction & $0 \%$ & $0 \%$ \\
\hline Educational Services & $2 \%$ & $0 \%$ \\
\hline Other & $2 \%$ & $2 \%$ \\
\hline
\end{tabular}

Looking at the distribution of various industry types for the nearby areas of Clifton and Norton Commons, similar patterns emerge as did in Chapter V, with the central neighborhoods. Norton Commons' nearby areas have nearly three times the professional services establishments as Clifton’s nearby areas, despite having significantly less total business. While the nearby areas of both neighborhoods have the same amount of business services establishments, business services establishments make up almost twice the proportion of industry outside of Norton Commons than is the case for Clifton's nearby areas. In total, professional services and business services establishments for the areas outside of Norton Commons double that of the areas outside of Clifton. Proportionally, the contrast is starker, as professional and business services establishments make up 37 percent of the industry outside of Norton Commons, and only 10 percent of the area outside of Clifton. This difference has primarily occurred due the area outside of Norton Commons catering to a wide range of healthcare concerns. This 
area has dental, pediatric, medical weight loss, veterinary, chiropractic, and allergytreatment establishments, as well as a full-scale hospital. Certainly, it could be surmised that with the prohibitive costs of healthcare, that an affluent area, such as that which surrounds Norton Commons, can best support such a bevy of healthcare options. Also, it is likely that this agglomeration is occurring due to proximity to the hospital. The interesting difference between these findings and those of Chapter V, is that an advantage in professional and business services industries did not translate to a greater number of skilled workplaces for the nearby areas of Norton Commons than the nearby areas of Clifton. This relationship was direct in the neighborhood-to-neighborhood comparison. The difference in this portion of the study appears to be accounted for by the sizeable advantage that the nearby areas of Clifton have over the nearby areas of Norton Commons in terms of total business. However, as stated earlier, Norton Brownsboro Hospital likely accounts for more skilled employment than all of these establishments combined.

By a count of 44 establishments to 16, the surrounding areas of Clifton have nearly three times the amount of industry classified as either distributive or personal services as do the surrounding areas of Norton Commons. As this type of work is largely made up of positions such as servers and retail workers, these totals are largely consistent with the massive advantage in unskilled job opportunity that the surrounding areas of Clifton have over the areas near Norton Commons. Proportionally, the nearby areas of Clifton still have a sizeable advantage in terms of this type of industry over the nearby areas of Norton Commons (80 percent to 60 percent), in terms of personal and distributive services establishments. The general presence of such industries is likely due 
to the total amount of business that the areas outside of Clifton are able to sustain. The presence of three social service sites (which is high within the context of this study) for the nearby areas of Clifton, with none for the areas near Norton Commons, is also significant. That Clifton or nearby residents may be able to access a childcare facility near their neighborhood is important as it relates to spatial social equity. Low-income, low-mobility parents would be able to meet this need in the Clifton area, whereas doing so would prove more difficult in the Norton Commons area.

\section{Comprehensive Analysis of Social Equity Indicators for Nearby Areas}

While there is limited data regarding the central importance housing indicators for the surrounding areas of Clifton and Norton Commons, the nearby areas of Clifton appear to have a significant overall advantage in their contributions to social equity, looking across the high importance, medium importance, and low importance indicators. As it relates to the high importance indicators, advantage for the nearby areas of Clifton shows up most strongly in terms of a prevalence of unskilled job opportunity and bus stops. These bus stops suggest that the unskilled job opportunity and transit-orientation of Clifton is reinforced by the area surrounding it. Norton Commons, conversely, gets very little help in these arenas from the areas surrounding its neighborhood. The disparity in results for these social equity indicators likely stem from the general lack of regard that New Urban communities have for the surrounding areas in planning their communities (Talen, 1999), the highly suburban and remote locations in which New Urban communities are often located (Trudeau and Kaplan, 2015), and the degree to which neighborhood boundaries are easily traversed in urban areas (Hays and Kogl, 2000). 
The nearby areas of Clifton fared moderately better than Norton Commons' nearby areas in terms of the medium importance indicators. These areas had an advantage in middle-income housing and amenities, while Norton Commons' nearby areas hold an advantage in terms of skilled labor opportunity. These advantages for Clifton's nearby areas may result from a likely correlation in high cost between New Urban communities (Jepson, Jr. and Edwards, 2010) and the areas surrounding them (Trudeau and Kaplan, 2015). An additional factor may be the level of density near Clifton, which allows for vibrant business communities (Pack, 2013), whereas Norton Commons’ nearby areas are sparsely populated, single-use suburbs. With the lower importance indicators, the strength of the performance of Clifton's nearby areas rests mainly upon its significantly lower frequency of automobile lanes, potentially contributing to the pedestrian safety of nearby residents traversing to and from Clifton.

The distribution of industry in the nearby areas of Clifton and Norton Commons mirror that of their central neighborhoods. Clifton's nearby areas are heavy in distributive and personal services, while Norton Commons' nearby areas are heavy in professional and business services. This difference is, again, likely tied to the ability of the areas near Norton Commons to sell more expensive services to affluent residents. Overall, the indicators have suggested that the nearby areas of Clifton have done more than Norton Commons' nearby areas to contribute to the social equity of the area as a whole in terms of housing accessibility, work for less mobile residents, transit, amenities, and pedestrian-safety. These findings are perhaps some indication of what New Urban communities miss out on by separating themselves from the areas that surround them. While Chapter V has presented data regarding how Clifton and Norton Commons may 
stack up in terms of social equity in a spatial sense, and Chapter VI has presented data regarding how their surrounding areas may contribute to the spatial social equity of these respective neighborhoods, Chapter VII will present data as to how the region as a whole might potentially be affected by each of these neighborhoods. 


\section{CHAPTER VII}

\section{REGIONAL COMPARISON OF SOCIAL EQUITY INDICATORS FOR CLIFTON AND NORTON COMMONS AND COMPREHENSIVE OVERVIEW OF FINDINGS}

This chapter presents the findings regarding the potential impact that Clifton and Norton Commons may have upon the region as a whole, from a social equity perspective. Additionally, these findings demonstrate the degree to which residents of each neighborhood may be able to access key parts of the region. These findings will address issues such as the ability of the urban poor to access each neighborhood, the ability of residents without cars to reach key regional unskilled employment centers, the total population that may exist within a reasonable transit radius of each neighborhood, and the economic diversity of the people within this transit range. The findings regarding lowmobility residents travelling to and from the neighborhood, within the region, will be addressed in the "regional transit orientation" section of this chapter. Then, the findings regarding the population that can reasonably access the neighborhoods through public transit will be addressed in the "potential demographic reach" section. After discussing the findings of both of these sections comprehensively, this chapter will conclude by summarizing the comprehensive findings from the neighborhood, nearby area, and regional comparisons of Clifton and Norton Commons. 


\section{Regional Transit Orientation}

Table 7.1- Results for Social Equity Indicators Related to Regional Transit Orientation for Clifton and Norton Commons 13.

\begin{tabular}{|c|c|c|c|c|}
\hline Indicator & Clifton & $\begin{array}{c}\text { Clifton } \\
\text { Transit Details }\end{array}$ & $\begin{array}{c}\text { Norton } \\
\text { Commons }\end{array}$ & $\begin{array}{c}\text { Norton } \\
\text { Commons } \\
\text { Transit Details }\end{array}$ \\
\hline $\begin{array}{l}\text { Transit Time } \\
\text { from Urban } \\
\text { Core to } \\
\text { Respective } \\
\text { Neighborhood }\end{array}$ & 21 minutes & No transfers & 91 minutes & $\begin{array}{l}1 \text { transfer, } 13 \\
\text { minutes } \\
\text { walking }\end{array}$ \\
\hline $\begin{array}{l}\text { Transit Time } \\
\text { to UPS } \\
\text { Worldport }\end{array}$ & 73 minutes & 1 transfer & 103 minutes & $\begin{array}{l}1 \text { transfer, } 13 \\
\text { minutes } \\
\text { walking }\end{array}$ \\
\hline $\begin{array}{l}\text { Transit Time } \\
\text { to Kentucky } \\
\text { Truck Plant }\end{array}$ & 84 minutes & $\begin{array}{l}1 \text { transfer, } 24 \\
\text { minutes } \\
\text { walking }\end{array}$ & 31 minutes & $\begin{array}{l}24 \text { minutes } \\
\text { walking }\end{array}$ \\
\hline $\begin{array}{l}\text { Transit Time } \\
\text { to Louisville } \\
\text { Assembly } \\
\text { Plant }\end{array}$ & 73 minutes & 1 transfer & 103 minutes & $\begin{array}{l}1 \text { transfer, } 13 \\
\text { minutes } \\
\text { walking }\end{array}$ \\
\hline $\begin{array}{l}\text { Transit Time } \\
\text { to General } \\
\text { Electric } \\
\text { Appliance } \\
\text { Park }\end{array}$ & 58 minutes & $\begin{array}{l}1 \text { transfer, } 11 \\
\text { minutes } \\
\text { walking }\end{array}$ & 105 minutes & $\begin{array}{l}105 \text { minutes, } 13 \\
\text { minutes } \\
\text { walking }\end{array}$ \\
\hline $\begin{array}{l}\text { Average } \\
\text { Transit Time } \\
\text { to Major } \\
\text { Regional } \\
\text { Unskilled } \\
\text { Labor } \\
\text { Employment } \\
\text { Facilities }\end{array}$ & 72 minutes & & 86 minutes & \\
\hline
\end{tabular}

(Source: Transit Authority of the River City) 
Figure 7.1- Ratio of Transit Times for Clifton and Norton Commons 14.

Blue- Clifton, Red- Norton Commons

*UrbanCore refers to transit from the urban core to the neighborhoods, while other trips are from the neighborhoods to various destinations.

*UnskilledJobs refers to the average transit times to major unskilled labor facilities in Jefferson County.

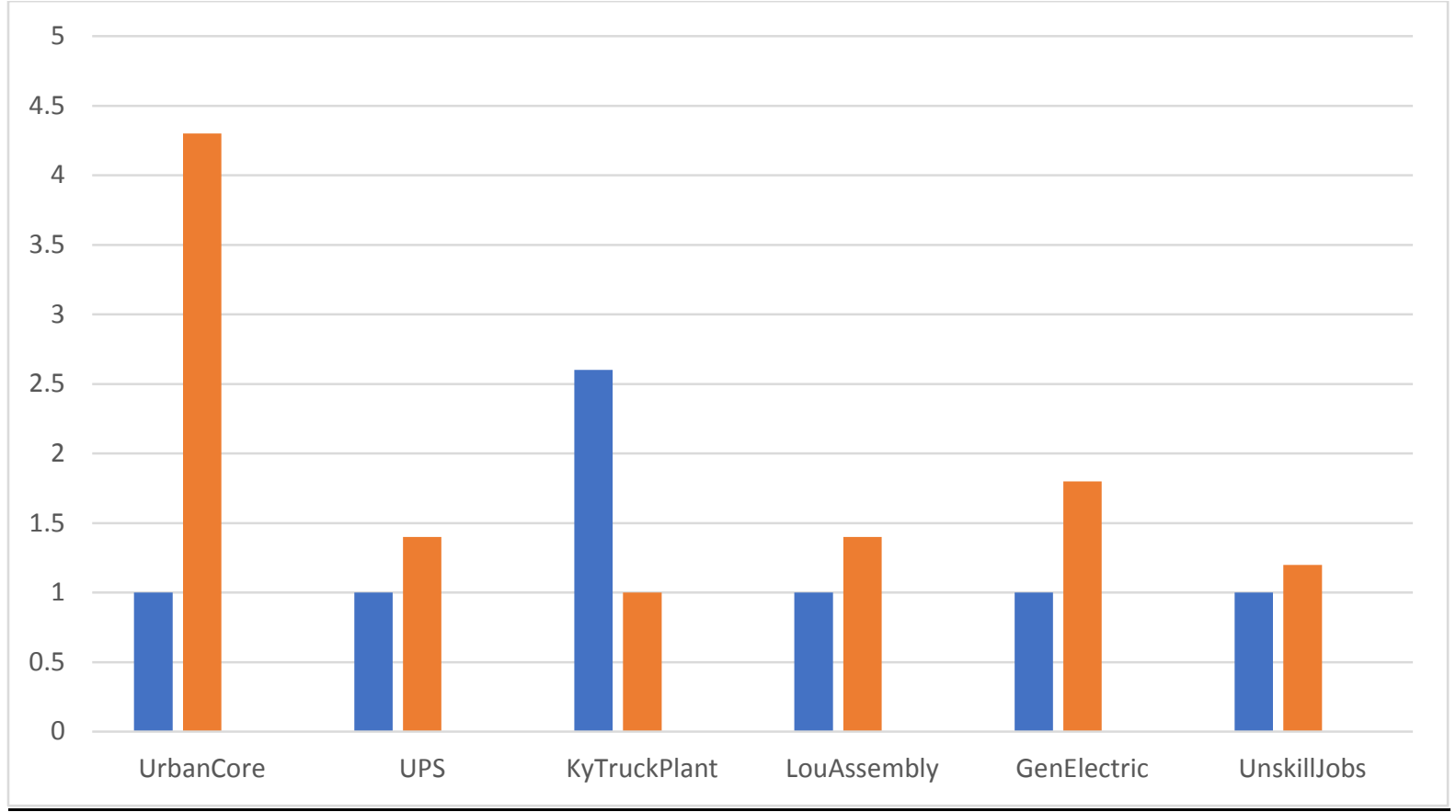

14 Lower totals are more favorable.

It takes over four times as long for an urban core resident to get to Norton Commons via city bus than it does to get to Clifton. The exact times are 21 minutes for the trip to Clifton and 91 minutes for the trip to Norton Commons. The average work commute time for all American residents is 25 minutes (United States Census Bureau, 2010). For the transit time of a poor urban core resident to Clifton to be shorter than the average American work commute, given the built-in advantage of factoring car drivers into that average, is a testament to how accessible job opportunities in Clifton may be for low-mobility residents. The 91-minute transit time from the urban core to Norton 
Commons mirrors the hopelessly long commutes that poor urban residents may generally face, when working in the suburbs (Dreier et al., 2014). These transit times are likely a problem that private New Urban communities, which are generally located in distant suburban areas, will often have difficulty reconciling.

Regarding transit to Jefferson County’s major unskilled labor employers, the average bus ride for Norton Commons residents is only about 20 percent longer than it is for Clifton residents. This average ride is 86 minutes for Norton Commons residents, compared to 72 minutes for Clifton residents. The relatively small disparity is due to the location of the Kentucky Truck Plant in northeast Jefferson County, allowing low mobility residents to access the plant from Norton Commons in 31 minutes. However, due to less than convenient bus stop locations in the Norton Commons area, 24 minutes of this commute are consumed by walking (with only seven minutes being on the bus).

It is worth noting, however, that Clifton offers shorter transit rides for three of these four major employment centers, with an average transit time 35 minutes shorter than transit from Norton Commons for these facilities. All three of these facilities require Norton Commons residents to travel over 100 minutes. To be fair, Clifton's transit times to these facilities, averaging 72 minutes, with the shortest time being 58 minutes (nearly an hour), are not especially efficient either. It would take low mobility Clifton residents over twice the national average for job commute time to reach each one of these facilities, and on average nearly three times as long. Thus, Clifton's moderate edge regarding these indicators is best described as a success only in relative terms.

The fact that public transit may not be an easy option for getting to work from either one of these neighborhoods may be partially attributed to the decentralization of 
employment nationwide (Tomer, 2012). It is likely also due to the general inefficiency of public transit in automobile-oriented, midsized cities (Jorge, 2012). The lack of a bus stop in Norton Commons, highlighted in Chapter V, is a significant factor in creating these long transit times for neighborhood residents. Residents must walk for 13 minutes, and outside of the neighborhood, to access the bus. Conversely, Clifton residents are likely to always be near one of the neighborhood's 19 bus stops. While neither neighborhood offers strong public transit options to major employers in the county, the two-way trips for Norton Commons residents would be nearly half an hour longer than they would for Clifton residents, on average. Additionally, such trips would be an hour longer or more to three of the four facilities when travelling from Norton Commons, as opposed to Clifton. Given the additional obstacles such difficult could bring to low mobility residents pursuing economic opportunity, it is fair to say that Clifton is at least moderately better in terms of its bus access to regional unskilled labor opportunity than Norton Commons. In addition to the findings of this section, it is worth noting that at some point in the future there may be access to additional major unskilled job facilities for Norton Commons if the I-265 bridge opens to bus traffic. As chapters II and IV discussed, the Amazon Fulfillment Center in Jeffersonville, Indiana, could be more accessible to northeastern Jefferson County if the Transit Authority of the River City incorporates the bridge into its transit system.

On the whole, Clifton is more transit-oriented than Norton Commons. Potential urban poor residents can access opportunity in Clifton substantially easier than they can opportunity in Norton Commons. Additionally, low-mobility Clifton residents are more able to access major unskilled labor facilities than are Norton Commons residents. In 
these regards, Clifton is more spatially-oriented towards social equity than Norton

\section{Commons.}

\section{Potential Demographic Reach}

Table 7.2- Households and Income Demographics of Census Tracts located within Five Miles of Clifton and Norton Commons.

* As stated in the Chapter IV (the "Methodology" chapter), the radii are five mile half-radiuses for each of these neighborhoods.

\begin{tabular}{|c|c|c|}
\hline Indicator & Clifton & Norton Commons \\
\hline $\begin{array}{l}\text { Total Number of } \\
\text { Census Tracts }\end{array}$ & 36 & 16 \\
\hline $\begin{array}{l}\text { Total Number of } \\
\text { Households }\end{array}$ & 43,784 & 26,538 \\
\hline $\begin{array}{l}\text { Proportion of Census } \\
\text { Tracts with } 25 \% \\
\text { Poverty Level or } \\
\text { Higher }\end{array}$ & $47 \%$ & $0 \%$ \\
\hline $\begin{array}{l}\text { Proportion of Census } \\
\text { Tracts with 50\% } \\
\text { Poverty Level or } \\
\text { Higher }\end{array}$ & $11 \%$ & $0 \%$ \\
\hline $\begin{array}{l}\text { Proportion of Census } \\
\text { Tracts with a Median } \\
\text { Income Below 30k } \\
\text { dollars per year }\end{array}$ & $22 \%$ & $0 \%$ \\
\hline $\begin{array}{l}\text { Proportion of Census } \\
\text { Tracts with a Median } \\
\text { Income } 30-50 k \text { dollars } \\
\text { per year }\end{array}$ & $31 \%$ & $13 \%$ \\
\hline $\begin{array}{l}\text { Proportion of Census } \\
\text { Tracts with a Median } \\
\text { Income above 50k } \\
\text { dollars per year }\end{array}$ & $47 \%$ & $87 \%$ \\
\hline $\begin{array}{l}\text { Proportion of Census } \\
\text { Tracts with a Median } \\
\text { Income above } 100 \mathrm{k} \\
\text { dollars per year }\end{array}$ & $0 \%$ & $33 \%$ \\
\hline
\end{tabular}

(Source: United States Census Bureau) 
Figure 7.2- Ratio for Clifton and Norton Commons of Various Indicators of Potential Regional Reach.

Blue- Clifton*, Red- Norton Commons

*In addition to these indicators, Clifton's potential reach has census tracts with high poverty levels, as well as census tracts with median householld incomes below 30,0000 dollars, whereas Norton Commons' potential reach has neither. Additionally, Norton Commons' potential reach has census tracts with median household incomes above 100,000 dollars, whereas Clifton's potential reach has none.

*These numbers refer to the ratio of the proportion of census tracts within a particular income range for each neighborhood, not the total number of census tracts for that neighborhood.

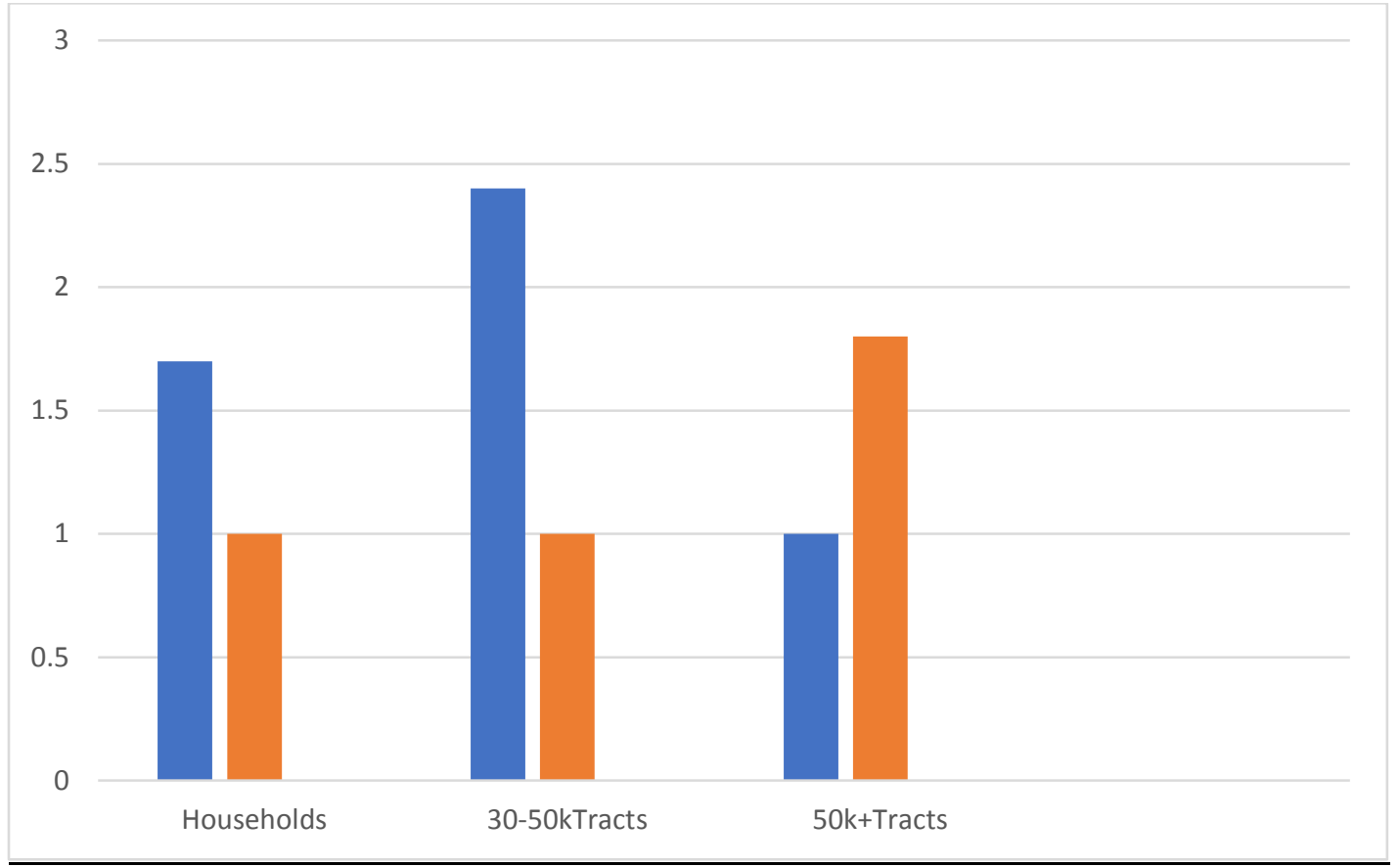

There are nearly twice as many households within Clifton’s potential regional reach than Norton Commons'. Thus, it is likely that far more people, in general, are able to reach Clifton at a reasonable pace through public transit than is the case for Norton Commons. The number of low-mobility, low-income residents within Clifton's transit range is quite large, as 47 percent of the census tracts within Clifton's potential reach have poverty levels above $25 \%$. This level of poverty is over twice that of the city of Louisville as a whole (United States Census Bureau, 2010). Several, or 11 percent, of the census tracts within Clifton's potential reach have poverty levels above 50 percent. 
Additionally, 22 percent of the census tracts within Clifton's reach have median household incomes below 30,000 dollars. The prevalence of low-income census tracts within Clifton's potential reach is indicative of the degree to which Clifton is accessible to low mobility residents throughout the region. Norton Commons has no census tracts within its potential reach matching any of the aforementioned low-income indicators. Thus, there is a significant disparity between the neighborhoods regarding transit accessibility to low-income residents in the region (in addition to the data from the previous section).

Nearly a third of the census tracts within Clifton's potential reach are middle income census tracts, while only 13 percent are middle income within Norton Commons' reach. Regarding affluent areas, 87 percent of the census tracts within Norton Commons' reach have median household incomes above 50,000 dollars, with one-third over 100,000 dollars. Alternately, 47 percent of census tracts within Clifton's reach exceed 50 thousand dollars for median household income, with none exceeding 100 thousand dollars. This exorbitant amount of affluent census tracts within Norton Commons' reach likely means that the people who could easily reach the neighborhood by public transit are unlikely to need or use this transit. On the whole, with a clear advantage in terms of low-mobility residents within an easy bus ride of its neighborhood, Clifton's potential regional reach appears more capable of impacting spatial social equity within Jefferson County.

\section{Comprehensive Analysis of Social Equity Indicators at the Regional Level for Clifton and Norton Commons}

Clifton performed more strongly than Norton Commons as it relates to indicators for transit-orientation to low-income residents. Potential consumer goods and 
employment in Clifton are significantly more accessible via public transit, for lowincome residents in the urban core than is the case for Norton Commons. Major unskilled labor employment facilities are moderately more accessible via public transit for Clifton residents than they are for Norton Commons residents. This advantage could, however, be impacted should the I-265 bridge open to public transit, affecting the transit landscape in the process. In terms of the income demographics of people located a reasonable transit ride away from each neighborhood, a significant number of census tracts within Clifton's transit range have large numbers of low-income residents. Conversely, Norton Commons' range is almost entirely affluent.

On the whole, Clifton has significantly greater potential than Norton Commons to spatially impact social equity in Jefferson County. As the results of Chapter V demonstrated, Norton Commons is an affluent neighborhood. Trudeau and Kaplan found that New Urban communities have similar housing costs to other housing within four miles (Trudeau and Kaplan, 2015). Norton Commons seems to be in keeping with these findings. Thus, it is likely that residents of Norton Commons and anywhere within several miles of the neighborhood are mostly affluent. Trudeau and Kaplan use their findings to defend the affordability of New Urban communities. However, these findings are relative to the surrounding communities of New Urban neighborhoods and do not provide absolute indicators of affordability. It is reasonable to speculate that such findings unintentionally point out that unaffordable New Urban communities, nationwide, may be located in equally affluent portions of their respective regions. 


\section{Comprehensive Overview of Neighborhood, Surrounding Area, and Regional Comparison}

On the whole, indicators used in this study have suggested that Clifton has greater potential to impact social equity on a spatial level than Norton Commons. Clifton has outperformed Norton Commons within this study at the neighborhood, inter-

neighborhood, and regional levels. This contrast suggests that urban neighborhoods that successfully undergo grassroots revitalization may have a greater chance of providing access to the poor than the typical New Urban community. This capability, for revitalized urban areas, applies not only to the confines of the neighborhood, but also adjacent areas, and the entire region.

Clifton's performance, regarding social equity at the neighborhood level, was strongest with the study's higher importance indicators. This success showed up primarily in the form of affordable housing, access to unskilled work for low-income citizens, access to essential daily goods, and access to public transit. Norton Commons was competitive with Clifton regarding other amenities that were given lower priority in the context of this study. Clifton has many more restaurants and total businesses, while Norton Commons was stronger in terms of parks and neighborhood schooling options. Additionally, Norton Commons had a higher degree of center-orientation for amenities, possibly making walking times for residents to these more balanced than is the case for Clifton. It is possible that New Urbanism is able to achieve some things through design, which has allowed Norton Commons to be competitive with traditional vibrant, urban areas on some indicators. However, there likely are highly important access issues that are impacted by market values, density, and metropolitan area location, which are not accounted for by New Urbanism’s design system. 
There is limited data upon which to make conclusions about low-income housing for the areas near Clifton and Norton Commons. However, as it relates to other socialequity indicators, the areas outside of Clifton outperform the areas outside of Norton Commons across the board. The areas near Clifton offer more unskilled labor opportunity than Norton Commons' nearby areas, as well as more accessibility to essential daily goods, more public transit access, and more amenities such as restaurants and schools. Such defecits for Norton Commons can likely be attributed to the lack of importance, during the development process, that New Urbanism places upon connecting with viable nearby areas. Additionally, these results are possibly impacted by the fact that New Urban communities, like Norton Commons, are typically built near undeveloped farm land or single-use suburbs (Talen, 2010). In Norton Commons’ case, the nearby area being evaluated is suburban in character, which offers an interesting observation, if the nature of this comparison is similar to what might be seen with other New Urban neighborhoods. Norton Commons did perform moderately better, within the context of this study, than did its nearby areas. While Norton Commons, on the whole, does not appear to have the same impact upon spatial social equity as strong, revitalized urban areas, this raises the question as to whether New Urban communities may fare somewhat better than suburbs by these standards. Nevertheless, regarding highly important issues such as the affordability of housing, and access to essential daily goods, Norton Commons offers little more than the suburbs which surround it.

According to the indicators of this study, Clifton has more potential than Norton Commons to impact the social equity of the region as a whole. The urban poor can more easily access Clifton than Norton Commons; unskilled employment opportunity is 
moderately easier to access through public transit from Clifton than Norton Commons; and many more low-income, low-mobility residents are within close public transit range of Clifton than Norton Commons. These observations may typify many private New Urban communities, as scholars have consistently found, over time, that New Urban communities are located at least ten miles away from the urban core (Fulton, 1996; and Talen, 2010). Additionally, private New Urban communities are found to be expensive in most cases (Talen, 2010; Prater, 2011; and Irazabal, 2013), with research showing that areas within several miles of these communities are priced similarly to the New Urban neighborhoods which they surround (Trudeau and Kaplan, 2015). Thus, there is reason to believe that there may be primarily affluent residents in the portions of the regions in which most New Urban communities are located.

Certainly, there are certain limitations within this study as to what can be stated by its findings. This study only serves as a microcosm of the potential impact of New Urbanism on social equity, but many of the conditions of Norton Commons are similar to most private New Urban communities. These similarities include Norton Commons' level of affluence, lack of focus upon density, and location within the metropolitan area. This study compares Norton Commons to what has been identified as a vital urban community within Louisville. It could be argued that a valuable study would be to compare the prototypical private New Urban community to a prototypical suburban community within the same region, considering New Urban communities are intended to be improvements upon the conditions of suburbs (Grant, 2013). However, if revitalization of urban communities such as Clifton is achievable, and the spatial impact upon social equity, as a result, is vastly superior to what is offered by New Urbanism, 
questions are raised about the ability of New Urbanism to achieve social equity goals. Additionally, the affluence and location of New Urban communities make unclear how private New Urban communities are likely to even have much more impact upon social equity than suburbs. With many of this study's findings being potentially relatable to New Urban communities nationwide, they offer a comprehensive look at how New Urbanism may have very little impact upon spatial social equity. Instead, this study suggests that a more fruitful pursuit would be to pursue urban revitalization. These weaknesses should be concerning to proponents of New Urbanism, given the progressive, social equity-oriented goals to which the movement has attached itself (Congress for the New Urbanism, 2016), as well as the principles upon which the movement was founded.

Scholars have noted some of the issues with New Urbanism highlighted in this study, such as a lack of affordable housing and the suburban location of New Urban communities within the metropolitan area. They have offered observations, suggestions, and policy recommendations as to what New Urbanism needs to do to be successful, or that will allow New Urbanism to be salvaged (Fulton, 1996 and Talen, 2010). However, sometimes it may not be appropriate to work too hard to make a concept viable. It could be the case, rather than fixing an existing concept so that it can remain in the intellectual lexicon, that similar goals might be better achieved by completely abandoning the concept and looking elsewhere. The policy recommendations later in this dissertation pursue such a direction, in advocating for the use of grassroots urban revitalization to achieve spatial social equity goals. However, in forgoing an attempt to fix or salvage New Urbanism, it must be articulated why potential observations or suggestions in support of New Urbanism should be bypassed. Thus, the next chapter (Chapter VIII) 
addresses likely defenses of New Urbanism, in the face of abandoning it for other concepts (Chapter VIII). Chapter VIII is followed by a thorough articulation of how grassroots neighborhood revitalization might be implemented in a fashion that produces more impactful results upon spatial social equity than New Urbanism (Chapter IX). 


\section{CHAPTER VIII}

\section{COUNTERARGUMENTS WITHIN NEW URBANISM}

The findings of this study suggest the use of New Urbanism to achieve spatial social equity would not be a fruitful path. The next chapter, Chapter IX, will offer alternative strategies to achieve spatial social equity, through grassroots neighborhood revitalization. Prior to discussing these strategies, this chapter will explain why it is necessary to bypass repairing New Urbanism, and instead focus upon altogether different strategies for achieving urban social equity.

Fulton (1996) argues that New Urbanism can only be part of the solution in achieving a desirable urban environment within a region. However, there should be concerns in allowing New Urbanism to even attract attention as a strategy to be used in conjunction with other strategies. This concern is especially warranted if New Urbanism offers very little in terms of social equity. There is the possibility that New Urbanism could divert focus and resources from strategies that have a much better chance of impacting urban social equity. For these reasons, in addition to discussing potential counterarguments as to how New Urbanism might possibly impact social equity, this chapter will also discuss counterarguments for New Urbanism based upon other relevant reasons, as well. The counterarguments discussed within this chapter are: 1) New Urbanism may not positively impact social equity, but it is essentially innocuous, having 
no negative impact either; 2) New Urbanism may not impact social equity, but it plays an important role in furthering environmental goals for cities; 3) New Urbanism should primarily be used in conjunction with Hope VI/Choice Neighborhood housing projects;

4) New Urbanism should form a marriage with dispersal ideology. In discussing each of these counterarguments, significant flaws with each of them will be articulated, in constructing an argument as to why it is necessary to turn to other strategies altogether.

\section{Counterargument 1: New Urbanism may not Positively Impact Social Equity, but it is Innocuous}

While it may be difficult to argue that New Urbanism positively impacts social equity, at first glance, it is challenging to see what harm the movement does either. It could be argued that, at worst, the creation of private New Urban communities essentially amounts to the continuation of suburban development. It may be difficult to see any additional harm that private New Urban communities do beyond what already occurs with existing suburban development. Certainly, Talen’s (2010) findings suggest that housing in private New Urban communities usually costs more than the average suburban home. These findings potentially suggest these communities have become enclaves for the affluent. But affluent subdivisions already existed without New Urbanism, so it could be argued that New Urbanism does little to negatively impact existing development patterns. Additionally, it is plausible that residents of private New Urban communities may very much enjoy living at these locations (Sands and Reese, 2007). It could be argued that these communities capture the appropriate level of density which people desire, as well as the nearby amenities which they value (Nelson, 2016). Ultimately, it could be argued that if affluent communities are to exist, then residents may as well have them designed in a fashion which they enjoy. 
Without a socially progressive component, however, private New Urban communities become the equivalent of a city building a really nice golf course, or an amusement park. Thus, private New Urban communities are essentially business products, or high-end amenities. It is problematic for New Urban communities to primarily serve such a purpose, given the social equity message which is embedded within New Urbanism. Also, with places like Norton Commons, there are planners, government officials, educators, and others lauding these communities, and working hard to create them (Norton Commons LLC, 2016). These contributions and this praise from community leaders could be derisively seen as growth machine politics (Molotch, 1976). Certainly, it could be argued that celebrating a high-quality amenity coming to the region is understandable, as long as there is no misconception that it serves some social reform purpose. However, there is something unseemly about having an expensive business product being celebrated as a harbinger for social justice.

Additionally, significant problems may arise if the focus of community leaders is misplaced, when they are presumably interested in improving quality of life for all people in the region. While it is difficult to quantify, such a misplaced focus would likely result in a significant amount of time, energy, and resources being diverted from pursuits which might actually impact social equity within the region. If all that New Urbanism is creating are fancy communities that the affluent enjoy living in, there needs to be a disconnect between New Urbanism and the lexicon of socially progressive ideology. This delineation could come in the form of referring to these communities as "New Urban resort communities”, for example. This disconnect could also be achieved by the founders of New Urbanism making a concerted effort to distance the movement, itself, 
from the creation of these affluent private New Urban communities. Doing so would be quite difficult, considering that many such communities, including Norton Commons, are designed by these founders 16 . Ultimately, though, scholars .cannot allow New Urbanism's inclusion in the discourse of social movements simply because NU arguably does no harm. The paradox is that allowing a seemingly benign business product to be categorized as socially progressive may result in damage, in the form of misplaced resources.

\section{Counterargument 2: New Urbanism may not Positively Impact Social Equity, but it Positively Impacts the Environment}

It has been argued that discussion of New Urbanism should move towards impact upon the environment, as well as the notion of community (Nasar, 2003). While the potential environmental impact of New Urbanism is not a focal point of this study, it must be acknowledged that the movement could still receive validation if it has substantial positive environmental impact. Even if New Urbanism does not impact the current day-to-day life of diverse income groups, a positive impact upon the environment would be a noteworthy social contribution. Environmental deterioration is a concern that could impact all of humanity at some point. For example, it is generally agreed upon that the increasing temperatures due to carbon emissions (often from driving), and the corresponding problem of rising sea levels, could destroy coastal cities within a century, if current habits are continued at the same rate (McKie, 2009).

More so than environmental issues, this study focuses upon the ten of the 15 Ahwahnee Principles that deal with access to various amenities. However, the remaining

16 Derived from DPZ.com, the website for the Duany/Plater-Zyberk architectural firm; May 2017 
five Ahwahnee Principles focus upon environmental issues, such as solar use and the preservation of the wild-life areas that surround a neighborhood (Fulton, 1996). It is difficult to say the degree to which Norton Commons achieves such environmental principles, given the limitations of this study. It likely requires a scholar specializing in environmental planning to adequately analyze these matters. However, the walkability of a neighborhood has an inherent environmental component to it (Lwin and Muriyama, 2011), along with the social components analyzed throughout this study. Studies have demonstrated through both computer analysis and practice that residents of New Urban communities drive less frequently than suburban residents (Kulash et al., 1990; Nasar, 2003). This New Urban-suburban dichotomy is presumably a function of there being more facilities within walking distance in a New Urban neighborhood, as opposed to a suburban neighborhood.

Norton Commons has just over 700 residents (Norton Commons LLC, 2016). If Louisville's suburban areas are defined as the portion of the metropolitan area outside of pre-merger Louisville, then the metro area's suburban population comes to about one million residents (United States Census Bureau, 2010). While small contributions to the greater ecological good should not be minimized, it should be noted that to whatever degree that Norton Commons residents reduce their driving, these residents only account for less than one-tenth of a percent of the Louisville metropolitan area's suburban residents (United States Census Bureau, 2010).

While potential environmental impact of New Urbanism through walk-ability is worth noting, the centerpiece of New Urbanism's goals for environmental impact is likely its principle of transit-oriented design. New Urban communities are supposed to 
act as streetcar suburbs of sorts, or as transit hubs (Nasar, 2003), facilitating the use of public transportation in the region. It must be noted that there are primarily two situations in which people use public transit: 1) If they are low-income and unable to afford a car, or 2) If driving a car from Point A to Point B is a more arduous task than taking public transit (Laffel, 2006). The first of these conditions is not by design, or through any planning goal. It is simply a side-effect of the social inequality and the sprawl that occurs in many mid-sized cities. As a city experiences sprawling development its urban core deteriorates. Low-income residents are forced to take long and inefficient bus rides to work, or to the grocery store, as a result of not being able to afford an automobile (Dreier et al., 2014). The latter of these two conditions represents the urban form that most in urban studies circles would prefer. Ideally, cities are designed or constructed to make residents want to use public transit instead of driving, regardless of income class (Laffel, 2006). An obvious example is New York City, where public transit use is far from limited to the poorest residents of the city. Residents use public transit, even when they can afford a car, because the level of population and density is able to support an effective public transit system (Laffel, 2006). The lack of availability of parking as well as traffic congestion also creates a scenario in which driving a car is quite unpleasant (Laffel, 2006). Thus, New York residents choose to use public transit, because it is a preferable option to driving.

While the example of New York is not reflective of what can be achieved in most cities, the aforementioned public transit principles must be adopted in other cities in order to improve their transit-orientation. Norton Commons is not geared towards these public transit principles in many regards. The data-gathering process for this dissertation 
revealed that Norton Commons' town center has an ample parking lot, which seems to concede that people will be driving to the neighborhood. Additionally, as Chapter V demonstrated, Norton Commons has not worked with TARC to produce a bus stop within the neighborhood. However, it could be argued that these deficiencies could be easily corrected. The larger problem with Norton Commons and other New Urban communities, as it relates to public transit, are fundamental regional issues that carry even greater weight than a neighborhood's design for transit use. Assuming that a transit-oriented design has been achieved for a New Urban neighborhood, with a town center with a transit stop and a lack of available parking, the next question is what places residents leaving the neighborhood will be able to access. Also, questions must be answered as to how residents throughout the region are going to be able to access public transit, in order to ride into a New Urban neighborhood.

Once again, Norton Commons accounts for less than one-tenth of a percent of Louisville’s suburban population. Additionally, mid-sized metropolitan areas nationally, where New Urban communities are most likely to be located (Talen, 2010), average only two New Urban communities per million residents (Town Paper, 2015). Thus, these communities are likely surrounded by an enormous amount of single-use suburban development. Residents exiting a New Urban community would almost certainly be headed somewhere that is not designed for efficient public transit use. In addition, residents travelling to a New Urban community from another part of the region would likely be coming from an area that is not designed for efficient transit use, either. Thus, as suburban infrastructures currently stand, residents within most regions are likely 
induced to use cars, rather than public transportation, to get to and from a given New Urban community.

New Urbanism was formalized as a movement nearly a quarter-century ago (Fulton, 1996). There is no indication that the pace of New Urban development can challenge America's existing single-use suburban infrastructure in order to facilitate public transit use. To be fair, perhaps parts of Fulton's (1996) suggestion that New Urban communities need to be part of a larger planning network may be occurring in Norton Commons and Louisville. The \$1.3 billion “Move Louisville” project intends to create 17 suburban transit hubs by 2035 (Fischer, 2016). Thus, it is possible that New Urbanism's transit hub principles may be complemented by additional efforts outside of New Urbanism. However, it has been 17 years since New Urbanism was formally introduced into Louisville's planning mission for its suburbs (Louisville and Jefferson County Planning Commission, 2000), with only one suburban New Urban community produced or proposed during that period of time. Thus, the proposal of planning goals, such as the production of an abundance of suburban transit hubs, may not necessarily equate to such goals being realized. It is quite common that major regional planning goals never reach fruition (Vogel and Harrigan, 2007).

Nonetheless, there are scholars suggesting that the next one hundred million Americans (a population to be added between 2010 and 2050) will be seeking small housing units, and advocating that abandoned suburban shopping malls be repurposed to suit these demands (Kotkin, 2010). These trends suggest that there may be a market for such suburban transit nodes. It could also be argued that this section's criticism, that suburban New Urban communities are incompatible with the large number of single-use 
suburbs that surround them, actually justifies the creation of a massive amount of suburban New Urban communities to combat this incompatibility. However, it remains unclear as to why a significant amount of focus and resources should be given to a goal that may or may not be attainable. It is not apparent why this time and money would be spent creating suburban New Urban communities and suburban transit hubs, rather than focusing upon revitalizing the urban core.

These concerns reflect the debate that has long occurred among scholars. Ellis (2002) argues that if New Urban communities are simply islands overwhelmed by a sea of freeway-oriented suburbs, then increasing public transit use will not happen. The sea of single-use development that surrounds New Urban communities is immense. The American suburban population grew from 27 percent of America's total population in 1950 to 52 percent in 2000 (Hobbs and Stoops, 2002). The counterargument is that transit investments, such as New Urbanism, are long-term, intergenerational, city-shaping investments that may not produce quick results (Bernick and Cervero, 1997). Questions remain as to whether patience in this process is truly warranted, as opposed to investing in other ideas.

Aside from allowing residents to ride public transit from suburb to suburb, another way a neighborhood can function as a transit hub is through possessing a centerorientation that allows people to congregate for travel to the urban core. Such a setup allows a neighborhood to essentially function as a streetcar suburb (Jackson, 1985), but this usually requires the urban core to have a level of density and vitality that makes parking problematic enough to dissuade driving to downtown (Laffel, 2006). This suggests that the primary urban strategy needs to be urban revitalization, with New 
Urbanism only serving a more limited role later, as a complement to this revitalization. It could not be argued that New Urbanism does much to help with revitalization of "innerring” suburbs, given the aforementioned distant location from the urban core.

There are some modest ways in which New Urbanism may positively impact the environment, if the movement implements things such as solar design (Rahnama et al. 2012), and if residents have more businesses to walk to in their neighborhoods than do suburban residents (Nasar, 2003). The danger, however, lies in allowing the movement to be embraced too heavily. Doing so amounts to embracing incrementalism, with no clear picture of where the movement is going (Forester, 1984). Also, similar to issues addressed in this chapter's previous section, overstating the potential impact of New Urbanism and drawing attention away from more fruitful pursuits can be problematic. While the focal point of this study relates more to the social components of sustainability than environmental components, it is important to discuss the limitations of New Urbanism's contributions to ecological sustainability. It could be argued that there is a degree of social good that is perceived to occur when something is done for the betterment of the environment. Thus, there is a concern that needed attention to urban revitalization, which might have a stronger impact upon both social equity and decreasing automobile use, may be diminished if planners do not take into account the limitations of New Urbanism's impact upon public transit use.

\section{Counterargument 3: New Urbanism will work as a Means of Revitalizing Public Housing through HUD}

Soon after the inception of New Urbanism, housing professionals were calling for increased economic diversity in public housing communities (Cavenaugh, 1992 and Spence, 1993). In many ways, the walk-able, income-diverse communities that Hope VI 
tried to create (Leinberger, 2008) may intuitively seem to represent a format that would allow New Urbanism to thrive as a mechanism for social equity. At face value, centrallylocated urban conditions, with the presence of low-income residents appear to create a situation that is compatible with the progressive goals of New Urbanism. Scholars argue that such strategies can end the uneven geography of economic and social opportunities (Briggs, 2005).

The program Hope VI began in 1992, evolving from an existing act known as Urban Revitalization Demonstration, which authorized the use of massive amounts of federal dollars to revitalize America’s public housing stock (Cisneros, 2009). Hope VI adopted a New Urban design, with leaders such as former HUD secretary Henry Cisneros concluding that the volatility and crime seen in existing public housing projects were partly created by inferior physical design (Cisneros, 2009). Through this federal funding there are many communities that Hope VI proponents claim as successes, such as Holly Park in Seattle, which was revitalized through a 500,000 dollar planning grant in 1993 and a 48 million dollar revitalization grant in 2005 (Engdahl, 2009). Aside from housing, the community consists of a learning center, a public library, several classrooms attached to South Seattle Community College, a Head Start Preschool, as well as other amenities (Engdahl, 2009).

While business development was not a focal point of Holly Park's revitalization, it must be noted that the neighborhood added many amenities that deal with access issues for low-mobility residents, something in which this study is greatly interested. As Chapter IV highlighted, the electronic access and other resources provided by libraries are key for job-seeking low-mobility residents (Maurer, 2015). Furthermore, Holly 
Park’s learning center and its access to South Seattle Community College provides career-development amenities that may not be available in many other neighborhoods. However, as will be discussed further later in this section, the question is whether such Hope VI communities are the most effective way of providing these amenities to urban communities, on a larger scale.

In addition to fixing the public housing communities themselves, Hope VI also played a significant role in the ideology of dispersal, an ideology to be discussed more in depth in the next section of this chapter. In short, the premise behind dispersal is that moving poor urban residents to better-off suburbs will increase their life opportunities (Imbroscio, 2010). Cisneros' decision to relax expectations for Section 8 vouchers allowed residents who left Hope VI communities to be dispersed into more affluent suburbs (Katz, 2009). Cisneros introduced many extensive policies to advance this larger goal of dispersal. Such policies included providing housing counseling to those who were dispersed under Hope VI, as well as funding clearinghouses to coordinate information regarding regional availability of housing and assistance (Katz, 2009).

There has been debate as to the effectiveness of Hope VI New Urban communities. Popkin and her collaborators laud the general success of many Hope VI communities, claiming that these communities have also revitalized the communities that surround them (Popkin, Katz, Cunningham, Brown, Gustafson, and Turner; 2004). Conversely, others have argued that constructing New Urban communities on former public housing sites has often left them unable to effectively integrate with the neighborhoods that surround them (Gilderbloom, 2008). 
In Louisville, one such Hope VI New Urban community is Park Duvalle. The assessments of this neighborhood have been mixed. Popkin and her co-authors argue that Park Duvalle is one of the Hope VI New Urban communities that has been successful at uplifting its surrounding areas (Popkin et al., 2004). Meanwhile, Hanka (2009) argues that Park Duvalle has failed to reach the level of cohesion with its surrounding areas of another Hope VI New Urban community in Louisville, Liberty Green. In addition, Park Duvalle has failed to achieve diversity, as only two of 1,273 residents are white (Hanka, 2009). Given the generalities of the comments of Popkin and her colleagues about Park Duvalle, it is unclear exactly what the referenced revitalization of nearby areas entails. Broadly, it does not appear that revitalization of the areas near Park Duvalle has happened in any meaningful way. While Park Duvalle has a poverty level of 6-25\% on the Louisville Poverty Map (recall Figure 2.1, from Chapter II), all of its surrounding areas remain in the $25-50 \%$ range, meaning that all of these census tracts still have poverty levels at least twice the city average (United States Census Bureau, 2010). While income-mixing is not the only way of measuring revitalization, looking at the level of poverty concentration in an area does offer a crude assessment of neighborhood improvement.

While this study deals primarily with how strategies provide access (to things such housing, employment, consumer goods, and public transit), it is important to also note the sociological questions surrounding Hope VI’s effectiveness. Hyra (2013) suggests that living next to more affluent people does not necessarily lead to increased levels of employment for low-income residents. Additionally, he finds that meaningful interaction across social classes is minimal in mixed-income neighborhoods (Hyra, 
2013). Martin (2007) asserts that in many cases social inequalities may be exacerbated in such neighborhoods, as low-income people withdraw from the community out of mistrust.

Often these mixed-income Hope VI neighborhoods have been accompanied with a programmatic attitude of behavioral training. Management of these programs often zero in on benign behavior that may be seen as less-civilized, such as drying clothes on one's balcony, congregating in the parking lot, barbecuing on patios, and other behaviors (Chaskin and Joseph, 2015). There are often double standards to these expectations, as the market-rate renters within the community are not held to these expectations (Chaskin and Joseph, 2015). For example, a group of low-income black youths congregating outdoors is often viewed differently in these communities than white college students engaging in the same activities (Chaskin and Joseph, 2015). Additionally, as Chaskin and Joseph (2015) examined Hope VI New Urban communities in Chicago, they discovered that low-income residents had their apartments inspected at seven times the rate of market-rate residents.

The findings are consistent with Marcuse' (2000) early assessment of New Urbanism, stating that the movement will be harmful to disadvantaged groups in the inner city, through creating social exclusion. Such divisions are seen in New Urban communities like Alexandria, Virginia’s Hope VI community. This development pairs residents making over 150,000 dollars per year with residents making less than 15,000 dollars per year (Hyra, 2013).

Several arguments have been made against top-down practices like those employed by Hope VI. Lin (2011) argues that efforts to salvage distressed areas must be 
spearheaded by the lower-income individuals themselves. DeFillipis and Fraser argue that internal networking will not only revitalize neighborhoods as a whole, but also enhance the employment prospects for the residents (DeFillipis and Fraser, 2010). United neighborhood efforts, like those discussed by the aforementioned scholars, can be difficult to create in Hope VI or Choice Neighborhood communities. Hyra notes that in such communities there are often separate resident associations for market-rate owners and subsidized renters (Hyra, 2013).

The primary goal of programs like Hope VI and Choice Neighborhoods is to tackle concentrated poverty, one of the most devastating urban phenomena, according to many scholars. There has been a general consensus across literature and policy to define neighborhoods with a 40 percent or higher poverty rate as having a high concentration of poverty (Wilson, 1987 and 1996; Jargowsky 1997 and 2013). Areas meeting this threshold come to be seen as distressed areas. However, studies have shown that residents from neighborhoods with 15-30 percent poverty grow up to have an 18 percent lower income than those growing up in neighborhoods with less than 5 percent poverty (Vartanian, 1999). Additional findings show residents from neighborhoods with over 30 percent poverty having annual incomes 21 percent lower than people growing up in low poverty neighborhoods (Vartanian, 1999). While this 30 percent threshold does not match up with the 40 percent threshold often used, these findings do indicate that moderate and high-level poverty neighborhoods are fairly similar in terms of the outcomes produced. Thus, there is a high burden upon Hope VI or Choice Neighborhood developments to drastically reduce a neighborhood's poverty level in order to achieve 
results. The gains produced by simply removing neighborhoods from "high" poverty level classification may be minimal.

There are those who disagree that it is necessary to move the poor to mixedincome areas for sociological purposes. Sampson, Morenoff, and Gannon-Rowley (2002) argue that there are methodological shortcomings to assertions that concentrated poverty affects social outcomes like educational attainment, fertility, marriage, and psychological and physical health. Imbroscio (2016) argues that the meritocratic notions of such arguments regarding concentrated poverty inaccurately suggest that people are denied opportunity by this phenomenon.

The largest fundamental problem with using Hope VI/Choice Neighborhoods New Urban communities to address social equity is not questions about effectiveness, but rather the cost of constructing them. In Louisville, both Park Duvalle and Liberty Green cost 200 million dollars to construct, apiece (Louisville Metro Housing Authority, 2016). For Park Duvalle, this cost averages out to approximately 170,000 dollars per unit (Louisville Metro Housing Authority, 2016), which is around twice the cost of the public housing which pre-dated New Urbanism, when adjusting for inflation (Schnave, 1992). While a price cannot necessarily be put upon progressive goals, funding for these pursuits is precious. Thus, the use of massive amounts of money for these goals needs to be very results-oriented. Chapter IX will get into this matter further, discussing how this money might be better used on urban grassroots efforts, potentially producing much furtherreaching results than Hope VI or Choice Neighborhoods.

There are other fundamental questions, aside from cost-inefficiency, regarding the expense of revitalizing public housing communities through New Urbanism. If such a 
practice does improve a neighborhood, and positively impact social equity in the process, it is unclear if this improvement would be due to New Urbanism, or simply due to a very large monetary investment. The question is, should the improvement be attributed to New Urbanism's supposedly innovative design scheme, or attributed to the massive amount of money that the neighborhood has attracted? It is arguable that New Urbanism's greatest success in revitalizing neighborhoods may be its ability to attract large public and private investments, rather than anything inherently productive about its ideology.

This question gets at what might be the largest inherent flaw of New Urbanism, which could potentially be an issue with both Hope VI New Urban and private New Urban communities. This flaw is that the rationale behind New Urbanism is essentially tautological in nature. Prior to New Urbanism formalizing as a movement in the early 1990s, scholars had already spent over a quarter-century lamenting the loss of the urban environment, perhaps most famously beginning with Jane Jacobs (1961). Eventually this study of urban decimation progressed towards William Julius Wilson's analytics-driven magnum opus, The Truly Disadvantaged. This book highlighted how the deterioration of urban areas left behind an enormous amount of racially-segregated, poverty-concentrated areas (Wilson, 1987). The problem is, New Urbanism has treated urban deterioration as a "what" question, rather than a "how" question. The aforementioned work of Jacobs and Wilson illustrate that it has long been obvious that urban, mixed-use, mixed-income, walk-able, transit-oriented communities rapidly disappeared in American cities. It is generally agreed upon that it would be nice for a variety of reasons, including spatial social equity, if cities could bring back such communities (Jacobs, 1961; Glaeser, 2011; 
Dreier et al., 2014). New Urbanism radically over-simplifies the issue by simply asserting, "let's bring these neighborhoods back”, without addressing the "how" question.

Though they have drastically different strategies for how to address urban deterioration, scholars typically address the issue with some recommendation of how to address the problem. These strategies range from public works (Wilson 1987 and 1996), to regional governance (Rusk, 1993), to mobility programs (Dreier et al., 2014), to innovative local developmental strategies (Imbroscio, 2010). Whether or not these various strategies are effective is open to debate. However, in each case, at least an attempt is made to explain how to deal with the loss of resources in struggling urban areas. In only asserting that what was lost from the urban environment needs to be replaced, New Urbanism's tautological approach shows up in how their communities have developed. One way to evaluate why urban areas have deteriorated is to say that the money, and thus the resources, have left the area. In keeping with this phenomenon, private New Urbanism has developed where money and resources are (Eppli and Tu, 1999 and 2013; Talen, 2010; Irazabal, 2013). Additionally, this section has discussed Hope VI New Urban communities that were created by stumping for large amounts of federal and private money. Ultimately, simply stating that the urban environment needs to be rebuilt in some form, as New Urbanism does, is essentially the equivalent of stating that a starving man in Africa needs to acquire food. The problem in such a case is not the need for identification of the obvious resource that the man needs. It is rather the more complex issue of how the man, and others like him, will be provided with food. This is to say that if New Urbanism's observations are largely derivative, and their approach is largely tautological, the movement begins to appear somewhat vacuous in nature. As 
different layers of New Urbanism are peeled back, it becomes increasingly questionable as to how it can be viewed as a viable strategy for addressing urban decimation. This is the case both from a social equity perspective and otherwise.

\section{Counterargument 4: A Marriage between Private New Urbanism and Dispersal Ideology will Aid in Creating Spatial Social Equity}

David Imbroscio (2010) has coined the term the "dispersal consensus" in critiquing the propensity of scholars to suggest that residents from high-poverty urban areas should be moved, through mobility programs, to affluent suburbs in order to improve their life chances. There is much to debate regarding the merit of dispersal ideology itself. However, there is a fit between the logic of both proponents of dispersal ideology and New Urbanism, suggesting that the two concepts could arguably be merged for progressive goals. Ultimately, it could be argued that such a marriage would be an improvement upon the initial premise of dispersal ideology. The leaders of dispersal ideology, including Dreier, Mollenkopf and Swanstrom, argue that the perimeteroriented, single-use design of suburbs have sucked access to jobs and consumer goods away from urban areas (Dreier et al.,2014). This shift potentially isolates low-income, low-mobility urban residents from these daily essentials. An obvious structural shortcoming in moving these residents to more affluent suburbs is that while there is supposedly more opportunity in these suburbs, suburban design is not such that lowmobility residents could easily access this opportunity. Ironically, this point is acknowledged by Dreier and his collaborators, as they point to the dangerous walking conditions and the inconvenient public transit in single-use suburbs (Dreier et al., 2014).

Within the thinking of dispersal proponents, an intuitive argument could be made that low-income urban residents should be moved to affluent private New Urban 
communities, instead of single-use suburbs. Doing so would theoretically offer the opportunity that supposedly exists in affluent suburbs, while also connecting lowmobility individuals with a design system that is friendlier towards accessing daily goods than is the case for traditional suburbs. The intuitive nature of this logic is seen in Talen's argument for improving New Urbanism. After critiquing the lack of affordability of private New Urban neighborhoods, she states that these communities need to do more to incorporate subsidies for public housing (Talen, 2010). Additionally, this marriage of ideologies is occurring conceptually in Norton Commons, with the neighborhood's affordable housing project. Chapter V identified this housing as being more of the lowermiddle class variety, but the project is still an example of an attempt to disperse poorer residents to an affluent New Urban neighborhood through public programs.

Imbroscio’s critique of dispersal ideology is a critique in a general sense, as opposed to a critique of its fusion with New Urbanism. Nonetheless, Imbroscio’s critique is that the concept of dispersal is ethically questionable and elitist, while it is also unclear that the life opportunities of a person are greatly enhanced by mobility (Imbroscio, 2010). Imbroscio argues that mobility programs do not take into account that residents may want to remain in their neighborhoods, while also assuming that the urban poor are intellectually incapable of determining what place of residence is in their best interest (Imbroscio, 2010). He further argues that data demonstrates that only a small fraction of a person's life trajectory is determined by the neighborhood they live in (Imbroscio, 2010). Ultimately, studies have found that at least 90 percent of difference between students in academic performance can be attributed to factors other than neighborhood factors (Elliot, D.; Menard; Rankin; Elliot, A.; Wilson; and Huizinga; 2006). In addition 
to the aforementioned issues, Chapter II of this study highlighted the NIMBY-ism (once again, NIMBY is an acronym for "not in my backyard”) which may occur towards lowincome residents if they are dispersed into affluent neighborhoods. Such a sentiment calls into question whether residents would even feel welcome in the neighborhoods to which they are dispersed.

In addition to the aforementioned general issues of dispersal ideology, there are also concerns that relate to the social access issues covered by this study which come into play with the fusion of dispersal ideology and New Urbanism. While private New Urban communities may seem like an improvement upon single-use suburbs in terms of providing access to daily needs, there is little reason to believe that they are strong enough in this regard to greatly benefit low-income residents. The findings of this study regarding Norton Commons, in addition to research regarding the fringe locations of private New Urban communities, suggests that many of these communities may be transit islands, very disconnected from the rest of the metropolitan area, in terms of public transit access (Ellis, 2002). Such conditions would not be ideal for low-income, lowmobility residents, and largely puts the burden upon a private New Urban community to be completely self-sustaining.

If the case of Norton Commons is representative of other private New Urban communities, then it would be hard to argue that private New Urban communities are self-sustaining. Norton Commons has considerably fewer unskilled labor facilities and consumer goods facilities geared towards daily needs than Clifton, the revitalized urban area analyzed in this study. It is quite possible that other private New Urban communities experience such deficiencies as well, considering they are noted to have an 
uphill battle in attracting retail (Gattis, 2008). As Chapter V noted, retail accounts for a great deal of access to daily necessities and unskilled job opportunity present in neighborhoods. These concerns about self-sustainability are corroborated by some current residents of Norton Commons. These residents state that while they don't mind low-income residents moving into the neighborhood, there is not enough development within the community, or enough transit access, to allow low-mobility residents to sustain themselves (Ryan, 2016).

Thus, it appears that the ability of dispersal ideology and private New Urbanism to fuse for the purposes of impacting spatial social equity is quite limited. While Chapter V's findings only represent Norton Commons, as a prototypical private New Urban community, the issues at play there are likely similar to other private NU neighborhoods. Research has noted that many such communities are isolated from transit at the fringes of metropolitan areas (Trudeau and Kaplan, 2015), and are relatively weak at attracting workplaces and consumer goods facilities (Gattis, 2008) for low-income individuals. Private New Urban neighborhoods would simply not offer low-mobility residents enough of an upgrade in access over their existing neighborhoods, or traditional suburbs, to warrant a marriage between mobility programs and private New Urbanism.

\section{Chapter Summary}

This chapter has discussed reasons why potential counterarguments to the findings of this dissertation within New Urbanism may not justify pushing the movement forward. Instead, it may be advisable to address urban decimation through other social equity-oriented strategies, such as grassroots neighborhood revitalization. In concluding, one point to remember is that New Urbanism cannot be viewed as a progressive 
movement simply by being innocuous. Second to, New Urbanism is potentially an inefficient means of making transit more eco-friendly. Third, the cost of New Urban Hope VI/Choice Neighborhoods developments call into question if there are more fiscally efficient ways to fix distressed urban areas. Finally, the infusion of low-income housing into affluent private New Urban communities does not seem to address the lack of mobility of low-income residents. The next chapter, Chapter IX, will explain how the strategy of grassroots neighborhood revitalization may be a more favorable approach than New Urbanism in addressing urban decimation and spatial social equity. 


\section{CHAPTER IX}

\section{EXPLORING THE GRASSROOTS ALTERNATIVE FOR SPATIAL SOCIAL EQUITY}

It is perhaps easier to empirically highlight why a particular strategy is ineffective at creating spatial social equity than to demonstrate why an alternative strategy will work better. To be certain, articulating the reasons why grassroots revitalization is the right strategy to replace the failings of New Urbanism presents certain challenges. As scholars have pointed out, there has been limited history of widespread, transformative success of grassroots revitalization in the United States (Cloward and Piven, 1999 and DeFillipis, 2001). In this sense, grassroots revitalization joins most other urban strategies, in that there is no existing record to show that either have been a revolutionary means of reversing urban decimation. If such a strategy existed, then likely it would have already emerged as the preeminent go-to method for such purposes.

Thus, it is not the aim of this chapter to demonstrate that grassroots neighborhood revitalization had an air-tight record of producing spatial social equity in the past. Rather this chapter will articulate why exploring grassroots alternatives, in new and innovative fashions, has strong potential to be a fruitful path toward social equity compared to New Urbanism and other strategies. In addition to serving as a strong point of comparison for evaluating Norton Commons throughout this study, the neighborhood of Clifton demonstrates what spatial conditions may look like when grassroots neighborhood 
revitalization is done well, and in the right situation. The results of this dissertation show that when compared to the typical New Urban community, successful urban regeneration may produce more affordable housing, more access to consumer goods, more access to employment, more access to such amenities in surrounding areas, and greater transitaccessibility. Thus, as such results are desirable, it is the aim of this chapter to present an argument for how to achieve these results through grassroots urban regeneration. In doing so, this chapter develops a specific proposal designed towards this end. At its heart lies a plan using redirected federally-funding to support community organizers to advocate for the needs of urban neighborhoods within the local political economy.

It must be noted that while there will be an experimental element to the suggestions offered in this chapter, other urban strategies such as New Urbanism have also been largely launched on experimental premises. In the time since its inception, New Urbanism has hardly offered enough evidence of success to warrant ignoring other experimental ideas. This lack of success, coupled with the fact that exorbitant amounts of resources have been dedicated to movements such as NU, calls for new strategies for urban revitalization (and achieving spatial social equity in the process) to be met with an open mind.

The results presented in Chapters V-VII do not examine the process behind them. They demonstrate how urban vitality may be more likely to achieve spatial social equity than New Urbanism. These results, however, cannot provide insight into how Clifton has achieved these results through grassroots organization. Nonetheless, in many ways this study has served as an expansion of the social equity considerations in Talen’s 2010 study, which thoroughly established the lack of affordability of New Urban communities 
(Talen, 2010). While Talen’s findings highlighted definitive problems with New Urbanism, these findings did not offer an obvious solution to the problem. However, in forming her policy prescription, Talen simply built an argument rooted in secondary research that incorporating public subsidies was the best way to address this problem (Talen, 2010). Similarly, rather than using information from the results of this study, this chapter will rely upon an argument rooted in secondary research positing that federallyfunded urban advocacy can achieve spatial social equity.

The remainder of this chapter will highlight the key elements of my proposal in brief, give an in-depth description of what the proposed federally-funded urban advocacy might look like in practice, discuss this proposal's relationship with existing research, and provide concluding thoughts about its potentialities.

\section{Proposed Federally-funded Urban Advocacy: An Overview}

My plan calls for funding urban advocacy by using federal dollars. Specifically, it calls for 200 million dollars to be allocated for a given mid-sized city, over a thirty-year period of time. A significant portion of this money would be used to hire advocates to be dispersed throughout its urban neighborhoods. Ultimately, the role of these federal employees will vary based upon the needs of a given community. But, in general, these hired advocates would spend their time fighting for policies favorable to neighborhood development within the local political system, as well as trying to foster community development and create grassroots neighborhood organizations. As this plan may allow as many as 40 advocates to work on the ground in a given city, it is possible that they could be deployed throughout the entire urban core. Thus, nearly every urban area has 
someone working on its viability. The precise number of employees, or the salary for that matter, is open to discussion. The point of these suggested numbers is to present a feasible framework by which large-scale, federally-funded urban neighborhood advocacy can occur. In addition to their individual neighborhood advocacy programs, these advocates could work to create citywide political coalitions to work for the regeneration of the urban core as a whole.

The following five key elements of this chapter's proposal for federally-funded urban advocacy are presented below: 1) The number of advocates needed for such a project, 2) the cost of such a project, 3) the distribution of funding, 4) the urban coalitions created within the project, and 5) the possibility of a nationwide replication of the project.

\section{1)Proposed Manpower for Federally-funded Urban Advocacy-}

In revitalizing urban neighborhoods, this proposal calls for hiring approximately fifty professional urban advocates for each city. The primary function of these advocates would be to work with a particular neighborhood, both establishing resident organizations and advocating for the viability of the neighborhood (perhaps through fighting for subsidies from the city for business development, promoting general policies which benefit distressed neighborhoods, or taking many other possible measures). If half of the two hundred million dollars (or one hundred million dollars) is used for personnel, this would allow for each of these advocates to earn about 50 to 70 thousand dollars over a thirty-year period of time. This salary range mirrors the median income of about 60 thousand dollars for city-county, county, and metro planners nationwide (American Planning Association, 2014). Admittedly, the median income of city planners (around 70 
thousand dollars) exceeds the salary range offered by this proposal (American Planning Association, 2014). However, this proposed salary range is still over twice the national median per capita income (United States Census Bureau, 2010), so it likely represents a comfortable professional salary by most standards.

Additionally, if this plan is replicated in many cities, it likely creates a vast job market for advocacy planners, which does not currently exist. Around two-thirds of urban planners are employed by local governments, with most of the other third employed either by state governments, or for technical services within private consulting firms (United States Bureau of Labor Statistics, 2015). Paul Davidoff (1965) called for competing plans within a city, which advocate for social problems to be addressed, outside of the plans created within local governments. The aforementioned employment landscape for urban planners does not suggest that there is much stable employment within advocacy planning, thus the jobs created within this proposal may be a welcome addition for idealistic planners.

Certainly, there is a degree to which advocacy planners may resemble community organizers in this context. However, the difference lies in the nuances of the goals of community organizers versus the hired advocates for which my plan calls. Many comparisons could be drawn between my plan and organizations such as the now-defunct Association for Community Organizations for Reform Now (ACORN) or National People's Action (NPA). Prior to its 2010 demise, some of ACORN's primary goals included creating affordable housing, increasing funding for struggling schools, and improving voter registration conditions for poor and minority residents (ACORN, 2002). It had an annual budget of 25 million dollars, with only 10 percent coming from federal 
funding (Theimer and Yost, 2009). It may have, in some ways, resembled a nationwide urban advocacy network in that at its peak it had over 1,200 neighborhood chapters in over 100 U.S. cities (Farrel, 2009).

The goals of my proposed advocacy network are more spatially-oriented than those of ACORN. My plan is centered primarily on revitalization of the area, rather than social justice for specific individuals, as is the case with ACORN. Also, the budget for my plan allows for the annual budget nationally to exceed 400 million dollars, which is 16 times ACORN's budget. From a federal-funding perspective, my plan allows for well over one hundred times the annual federal contribution of ACORN. The large number of paid employees resulting from this funding would allow much more expansive coverage of urban areas nationally than ACORN, as well as presumably generating a larger total membership.

\section{2) Proposed Budget for Federally-funded Urban Advocacy-}

The proposed budget for this plan is 200 million dollars, to be used over a thirtyyear period of time, which is intended to replicate the common cost of a Hope VI/Choice Neighborhood development. The key element of this dollar amount is that such a budget gives an idea of how much can be done through urban advocacy, if the enormous funds of HUD-initiated New Urban communities were redirected away from physical development, and toward grassroots involvement. Chapter VIII argued that Hope VI/Choice Neighborhood communities require a tremendous amount of money to be spent revitalizing one neighborhood, while largely ignoring the need for revitalization of the neighborhood's surrounding urban core as a whole. Redirecting such funds towards 
urban advocacy opens up the possibility for more of a city-wide approach to revitalization, as opposed to resting hopes so heavily upon one neighborhood.

\section{3) Proposed Budget for Non-personnel Purposes-}

If only half of the budget for a given city is used to staff their advocacy efforts over a thirty-year period of time, then one hundred million dollars remains for other purposes. These remaining funds illustrate how much further a large source of funding goes for the purposes of manpower, as opposed to using this money for elaborate construction, such as HUD-initiated New Urban development. The remaining money could function as a funding bank for a given city, with different neighborhood groups petitioning for funds for things such as small business loans, small parks, or other needs.

This one hundred million-dollar funding bank should not be interpreted to be a finite source of funding for urban regeneration. It is assumed that the advocates and the organizations that they create will be fighting for additional city, state and federal dollars to support their neighborhoods, and the urban core in general.

\section{4) Proposed Creation of Urban Coalitions-}

Upon advocates establishing their positions in a given neighborhood or area, it is then possible for advocates throughout a given city to also create a citywide urban coalition, amongst themselves, and potentially the organizations which they create. The creation of such coalitions allows for this advocacy project to serve not only the needs of individual neighborhoods, but also address general needs relating to the vitality of the corresponding urban core. In the process, this coalition can fight to improve things like transit access, job accessibility, and access to consumer goods for residents across income groups. 


\section{5) Proposed Replication of Project as a Nationwide Urban Policy-}

The 71 largest metropolitan areas in the United States all have over 750,000 residents (United States Census Bureau, 2010). A few of the largest cities, such as New York, San Francisco, and Washington, D.C., have problems which are quite the opposite of urban decimation —-their urban cores are so thriving that they face issues with the rising costs of gentrification (Freeman and Braconi, 2004; Smith, 2007; Hyra and Prince, 2016). For the purposes of discussion, it could be argued that the cities of all metropolitan areas smaller than San Francisco, which is ranked $11^{\text {th }}$ in the United States in population (United States Census Bureau, 2010), could be included in this project. Thus, the project would apply to metropolitan areas with populations between 750,000 and 4.2 million residents. To say that this program could potentially be applied to 60 cities nationwide suggests that a tremendous amount of the mid-sized American cities that have a large population living in, or surrounding, decimated urban areas could be covered by this plan. Applying this program to 60 cities would roughly cost only one percent of HUD’s annual budget (HUD, 2016). Of course, the program could be launched as an experiment in a smaller number of cities first, but the point is that it is quite feasible for this to function as a nationwide urban policy. The exact parameters could be debated, but the focal point would be mid-sized cities.

\section{Proposed Federally-funded Urban Advocacy: Discussion}

There are a number of things to understand in implementing this proposed plan for federally-funded urban advocacy: 1) revitalizing “urban areas” can refer to either distressed areas or areas ripe for revitalization, 2) this plan's commonalities with the argument for progressive localism, 3) federally-funded community organization from the past, through President Lyndon B. Johnson's Great Society, and 4) Louisville’s current 
relationship with neighborhood organizations. Each of these considerations will be described in this section.

Following these considerations, this section will conclude with a detailed discussion of the implementation of this chapter's plan.

\section{Two Types of Urban Revitalization}

In introducing these policy prescriptions, it must be understood that for the purposes of these recommendations there are two types of urban revitalization. The first type could be referred to as "general urban revitalization”, which is likely how Clifton’s revitalization efforts would be classified. General urban revitalization could be described as revitalization occurring in an area which is not necessarily in distress. Such an area may have conditions which make it more favorable to revitalization. Nonetheless, after such revitalization, many of the structural elements which contribute to spatial social equity are in place, in the form of mixed-income housing, access to daily goods, access to employment opportunity, and transit-orientation. Many Hope VI New Urban developments occurred in areas where conditions were ripe for revitalization (Popkin et al., 2004; Katz, 2009), a fact which Popkin and her co-authors critiqued. It could be argued that while there are fundamental issues with Hope VI/Choice Neighborhood New Urbanism, revitalization occurring where conditions are favorable is not necessarily problematic. Again, within the paradigm of grassroots revitalization, it could be argued that Clifton is such a neighborhood. It is clear that meaningful results may occur in Clifton and other similar areas, in that they structurally support spatial conditions which favor social equity. Thus, while strategies for urban revitalization should not only focus 
upon ready-made areas, it would be ignoring opportunity to impact social equity if urban strategists did not make general urban revitalization part of the plan.

The second type of revitalization which this chapter will focus upon could be referred to as "distressed area revitalization”, which would often refer to urban areas with heavily-concentrated poverty, such as those seen in west Louisville. Typically, these are communities which would be considered to be in urgent need of revitalization. These impoverished areas are generally the places which have most troubled scholars, in terms of the devastating social effects of urban decimation. The number of concentratedpoverty census tracts tripled in size and doubled in population over the last quarter of the 20th century, while retaining these totals well into the 21st century (Jargowski, 2013). Thus, it remains a noble and necessary cause to address revitalization in distressed areas, in addition to general urban revitalization.

Some might argue that a third type of revitalization, with a potentially negative connotation, exists in the form of gentrification. As Chapter III discusses, gentrification rarely occurs to the point to where property prices force out existing residents, which only happens in select, large cities (Buntin, 2015). With this fact in mind, the strategies discussed in this chapter are primarily aimed at mid-sized cities which may be less susceptible to such gentrification. Also, displacement from gentrification is more of a negative side-effect than an intended goal of urban advocates. Thus, the strategies of this chapter will focus more upon the other two types of revitalization mentioned above.

\section{Comparison to Progressive Localism}

Prior to describing these revitalization strategies, it important to note the parallels between the work of Imbroscio and this study's preference for grassroots neighborhood 
revitalization, while critiquing New Urbanism. As outlined in Chapter VIII, Imbroscio condemns dispersal, a top-down strategy like New Urbanism, as a means for addressing the social inequity incurred from urban decimation. Imbroscio claims that such strategies are elitist, obstruct residential autonomy, and are limited in effectiveness (Imbroscio, 2010). Following up this criticism, Imbroscio advocates a set of progressive localist policies instituted on-site, at the neighborhood level, within distressed urban areas. He calls for communities to adopt strategies like calculating the public cost and benefits of various developments and policies, in order to influence decision-making (Imbroscio, 2010). Additionally, Imbroscio advocates for economic development detached from the typical inequities of the neoliberal corporate economy, by promoting community ownership of business (Imbroscio, 2010). Imbroscio’s critique amounts to favoring urban revitalization at the grassroots level, as opposed to moving residents out of decimated areas to "better" suburbs.

The premise of this dissertation similarly relies upon grassroots revitalization to deal with urban decimation. In the case of the recommendations of this chapter, they are in opposition to artificially manufacturing urban areas in the suburbs, as New Urbanism attempts to accomplish. Of course, this chapter's condemnation of these artificiallymanufactured communities applies to the idea of placing them in distressed urban areas as well, due to the over-simplification of such ideology (discussed in Chapter VIII). There is much in common with New Urbanism as a planning strategy and the liberal expansionist urban governance strategies which Imbroscio criticizes. Similarly to the arguments of this dissertation, he argues that such strategies wrongfully insist upon 
methods of connecting the struggling city to outside areas within the region or county, rather than pursuing on-site community development (Imbroscio, 2010).

While there is much that this chapter's recommendations will borrow from Imbroscio's ideology, where they will diverge is that I call for grassroots revitalization efforts to form a connection with a major funding source. This funding should perhaps be in the form of HUD, or the federal government in general, in creating a large-scale formal organizational structure to support such efforts. There is a degree to which this may create a bit of a paradox in referring to such efforts as "grassroots". However, regardless of the terminology, such efforts would continue to be on-site and heavily dependent upon residential involvement. Certainly, such a strategy may be open to some of the similar criticism which Imbroscio forwards regarding liberal expansionism. Ultimately, the proposal of this chapter will require a degree of paternalism which is absent from Imbroscio’s progressive localism (Imbroscio, 2010). Thus, there is a degree of compromise to be acknowledged in the forthcoming suggestions. Nonetheless, these are concessions made in order to put grassroots neighborhood revitalization in touch with substantial resources, to get a large-scale movement off the ground.

\section{Louisville and Neighborhood Organizations}

It must be acknowledged that some cities do already have formal organizations which attempt to facilitate grassroots neighborhood revitalization. In Luisville such an organization is the Center for Neighborhoods. The Center for Neighborhoods does appear to have positive goals for communities through training courses for neighborhood activism, connecting neighborhoods to economic development, accessing the power structure, organization building, strategic planning, and other pursuits (Center for 
Neighborhoods, 2015). However, what may vary substantially between such organizations and the strategies to be suggested in this chapter is the scope and ambition of the outreach. The Center for Neighborhoods boasts that it is has hired two new employees to serve as neighborhood liaisons (Center for Neighborhoods, 2015). Conversely, the number of activists my plan will call for being dispensed into various neighborhoods, on a daily basis, is vast in nature.

Additionally, there is some concern that the Center for Neighborhoods relies too heavily upon collaborating with the city government (Center for Neighborhoods, 2015), which could set up a dynamic that too much resembles the negotiations of Urban Regime politics (Stone, 1989). The result could potentially dull or limit the gains of activist efforts. In short, Urban Regime Theory rests on the notion that a particular corporate regime exists for each city, with which local governments must negotiate (Stone, 1989). Questions arise as to whether Louisville’s Center for Neighborhoods has more of a cooperative relationship with the city government than a combative relationship. Given the business dynamics which may dominate a city government, a cooperative relationship with the local government may lead an organization to achieving neighborhood gains which a regime allows (Holman, 2007), rather than achieving gains which the organization has demanded.

\section{Cost of Plan/Counterargument for Non-spatial Redistribution}

The final point to be addressed before introducing this proposal’s large-scale grassroots measures is the relationship between the cost of such a project and counterarguments for non-spatially oriented redistribution. The recommendations of this 
chapter will call for a 200-million-dollar expenditure spread out over a thirty-year period of time, for a given city. The total dollar amount is intended to replicate the level of expenditure for creating a Hope VI/Choice Neighborhood New Urban community, to create a framework for comparison. The funding for such New Urban communities come from some combination of HUD funding and private contribution (Cisneros, 2009). With some of the funding being private, it is possible that some of it is in the form of investors who expect some return on their investments. Thus, it may not be reasonable to state that the money for a HUD-created New Urban community could be directly used for the project proposed in this chapter. However, the budget for HUD has ballooned to 48 billion dollars (HUD, 2016). The roughly seven-million-dollar per year expenditure called for by this chapter's proposal would require just over one one-hundredth of a percent of HUD's annual budget. This budget is reasonable for a project which is designed to impact an entire city, rather than a select community. Moreover, such a comprehensive city-wide project could be instituted in over sixty mid-sized cities nationally, for less than one percent of HUD’s annual budget. Given that this proposal could nearly be described as a nationwide urban policy, it also constitutes a very reasonable request from HUD. Ultimately, it would still leave the department with almost all its entire budget to address whatever other needs may remain.

Heretofore, using large amounts of funds for Hope VI and Choice Neighborhoods has been a dominant federal urban strategy. Implementation grants as high as 50 million dollars were granted to the 40 largest housing authorities which were struggling (Turbov and Piper, 2005). Again, Park Duvalle in Louisville is one of these heavily-financed projects. Turbov and Piper claim that the neighborhood is more economically viable as a 
result, highlighting that Park Duvalle’s median household income grew by 193 percent between 1990 and 2000 (Turbov and Piper, 2005). It is possible that this growth is a result of attracting more middle-class residents into the neighborhood, as poorer residents left. Nonetheless, an argument could be made that an increased median income brings the possibility of attracting more resources into the neighborhood. This migration could theoretically create more accessibility to daily needs for neighborhood residents, through an enhanced business presence. Additionally, this income shift likely satisfies the threshold discussed by this dissertation which supposedly creates the social benefits of mixed income (Dreier et al., 2014). However, it must be reiterated that it is unclear how gains which may be experienced in Park Duvalle have much impact on the rest of the struggling urban core.

Through facilitating grassroots operations, the proposal of this chapter is intended to impact social equity spatially. Certainly, some may argue that if previously misappropriated funds are to be redirected, they may be better served through peoplebased, rather than place-based, redistribution. There is a compelling argument that issues such as job loss from globalization, the roll-back of social programs, and corporate governance have had a greater impact than spatial phenomena upon spatial social equity (Sclar, 2002 and Sassen, 2012). This study and its corresponding proposal does not dispute such a notion. Rather, it has simply been the aim of this study to focus upon place-oriented issues within the context of the degree to which they are important, more so than over-inflating their importance. But in this particular case, it is quite possible that the place-based goals within this chapter's strategy will be more impactful than what could be accomplished for Louisville through people-based redistribution. Commonly, 
such people-based redistribution comes in the form of direct cash transfers to reduce inequity (Lustig, 2012). As opposed to my proposed strategy, a redistribution of 200 million dollars to all of the impoverished residents of Jefferson County would amount to a one-time payment of approximately two thousand dollars per person. Alternately, such a transfer could come in the form of 70 dollars per year, spread out over a thirty-year time period. Conversely, the plan this chapter is calling for is an attempt at a comprehensive revitalization of the urban core. Thus, it could reasonably be argued that place-based policies would be more impactful, in this case.

Lessons from the Past: The Great Society and Community Organization

It could be argued that the most prominent examples of federal urban policy existed under President Lyndon B. Johnson, with programs he instituted through "The Great Society”. The corresponding creation of community action agencies (Kurian, 1998) and The Model Cities Program (Klemens, 2007) particularly reflected a concern for declining urban neighborhoods within the Johnson administration. These programs focused heavily upon economic development (Kurian, 1998) and providing boots on the ground (Walka, 1972) for these neighborhoods. This section discusses these Great Society urban programs and how they inform my proposed federal urban policy.

In the case of my proposed plan, the primary resource called for is manpower. Manpower is a relatively cheap resource, compared to reconstruction of the built environment, such as with a 200- million-dollar New Urban community. Under this plan, only half of the proposed 200 million dollars for a city would need to be spent on personnel. The other hundred million dollars could be put in an account to provide other resources to help the cause. With this funding, a city like Louisville could hire 
approximately fifty career-long professionals to earn $\$ 50,000-\$ 70,000$ over the course of their thirty-year career. Assuming an office-based staff of ten or so, for bureaucratic, data-analysis, and planning purposes, forty employees could be dispersed into various urban areas throughout the city. Their work days could primarily be spent identifying the needs of their assigned neighborhoods, as well as advocating to government and business leaders, and working to build strong neighborhood activist groups. While it might seem strange for the federal government to fund advocacy groups, there is some precedence for this. Voter education projects are heavily advised by the federal government (United States Election Assistance Commission, 2014).

In addition to voter education projects, this strategy shares commonalities with elements of the President Lyndon Johnson's Economic Opportunity Act. As part of the 1964 Economic Opportunity Act, Community Action Agencies were formed in conjunction with the War on Poverty. The act also created the Economic Opportunity Council, which launched smaller independent groups to work with communities to establish better economic climates (Kurian, 1998). Usage of this program has been on the decline. President Obama cut the 654-million-dollar annual budget for the program by 350 million dollars in 2011 (Lew, 2011). Data available from the use of this program in the state of New York indicates that the program may be geared more towards general federal assistance than spatial inequity. The program provided 131,000 New York City residents with additional financial assets or skills, but only lead to 38,000 residents becoming engaged in community empowerment (Cuomo, 2015). Certainly, there is nothing wrong with programs which contribute to the social safety net for struggling communities. However, the programs set up by the Economic Opportunity Act do not 
constitute comprehensive urban advocacy programs. Thus, programs proposed within this chapter provide a meaningful addition to existing federal urban policy.

The Model Cities Program was also created out of the War on Poverty. More so than the aforementioned aspects of the War on Poverty, the Model Cities Program did focus on citizen involvement (Klemens, 2007). Many urban leaders were created from this program, particularly African-Americans (Klemens, 2007). Ultimately, the program was discontinued in 1974, as American political sentiment became more conservative in the late 1960s, as a result of urban riots (Weber and Wallace, 2012). Federal urban aid moved much more in the direction of the built environment after the dissolution of the Model Cities Program (Weber and Wallace, 2012).

Research that was contemporary to the Model Cities Program suggests that within the program's neighborhoods, the participation of residents often hovered at only one percent (Walka, 1972). Walka notes that there are also issues regarding the ability of residents to relate to Model Cities staff members, as this staff was often educated and upwardly mobile (Walka, 1972). The impact of this disconnect, and residential perception of patronization, often led residents to feel as if they were clients addressing professional planners (Walka, 1972).

Certainly, there are lessons to be learned from the Model Cities Program, which sheds light on potential issues with this chapter’s proposal for federally-funded urban advocacy. Societal attitudes may be more favorable for community action than what was experienced during the Model Cities Program, as racial attitudes have advanced significantly since the late 1960s. However, there is a need to ensure that nothing similar 
to the urban riots of that time period are repeated, thus peaceful activism must be encouraged.

While Walka's (1972) research bemoaned the low numbers of participation within the Model Cities Program, it must be noted that the Clifton Community Council also represented a very small portion of Clifton's population. The lesson from this level of participation within the CCC may be that a lot can be accomplished within a neighborhood with a relatively small number of residents (when they are organized). Thus, while there should always be considerations as to how to increase citizen participation in neighborhood organizations, groups of twenty or thirty residents should not be dismissed as useless. This involvement still provides a meaningful base of residents to organize festivals, attend city hall meetings, and fight for funding and favorable local legislation.

Additionally, the disconnect which Model City residents felt towards the paid program workers in their neighborhoods (Walka, 1972) needs to be addressed. This problem can partially be addressed by targeting advocates who are demographically representative of the neighborhoods, as well as accounting for a portion of these hired advocates with residents who have achieved their skillset through activist experience rather than formal education. These practices can only go so far, however. Within this chapter's proposed plan, there almost certainly will remain a sizable contingency of advocates who may not be relatable, on paper, to low-income residents. Also, the cities within this chapter's plan will not be able to only use advocates with experiential knowledge, as there needs to be a reasonable number of formally-trained advocates within a city's urban coalition to help shape the direction of that city, as well as to inform 
experience-reliant advocates, when necessary. Thus, the goal needs to be to understand how to manage the disconnect with assigned advocates that neighborhood residents can potentially feel.

It is important for the advocates to remember that they work for their neighborhoods and their residents, not vice versa. The assigned advocate needs to sense when residents are resistant to certain pursuits and adjust accordingly. There are still many things that an advocate can do behind the scenes for a neighborhood, if conditions are not yet ripe for citizen involvement. The advocate also needs to simply identify his/herself as a planner for the federal government. Establishing this role will make clear that it is the advocate's job to help to improve urban conditions in general, rather than identifying the neighborhood as their personal project. Certainly, there needs to be an effort to recruit a volunteer resident leader, in addition to the advocate, to create a sense of ownership of the effort with neighborhood residents. Ultimately, a relationship should be established which highlights how the advocate can serve the community. This process should lead to understanding what the neighborhood wants, and conveying that the advocates role is to use their training to help them achieve these goals.

An additional takeaway from the failures of the Model Cities Program is the need for patience. With the program lasting only nine years (Weber and Wallace, 2012), there simply was not enough time to declare federally-funded urban advocacy a failure. Instead questions needed to be asked as to how to fix such a program, and what had been learned. New Urbanism has been given over 25 years, and counting, in urban studies dialect, with little indication of success within the movement. In the case of New Urbanism, it is a fixed design movement. Neighborhood activism is a broad concept, 
which can be adapted based upon what a neighborhood needs. Thus, giving federallyfunded urban activism less than a decade before declaring it a lost cause is premature.

\section{How the Plan for Federally-funded Urban Advocacy will Work}

There is much to consider when implementing my plan for federally-funded urban advocacy: 1) how the funding structure might work, 2) the distribution of the advocates, 3) the plan's local economic development strategies, 4) the political components of the plan, 5) the role of the plan's urban coalitions, 6) the type of training which the advocates may receive, 7) and how the plan can potentially impact the urban power structure. The remainder of this section will outline all of these components of my plan.

Relating to the funding of this chapter's proposal, the additional one hundred million dollars (aside from the hundred million used for hired advocates) could be used for various needs which are vied for by neighborhoods throughout the city. The portion of the staff for this project which is not working in the neighborhoods could be in charge of managing the budget. Advocates for various neighborhoods would present their needs to this budgetary department. There are specifics to work out regarding what organizational structure would be used to determine budgetary priorities for a given city, which is something that could be resolved. Use of this funding could include small business loans, park construction, or other needs. This budget should not be seen as a finite source of funding, as there are currently activist groups, without any such funding pool, frequently advocating for miscellaneous government money for projects to improve their neighborhoods (Libby, 2012).

The proposed activists can be distributed somewhat evenly, both in neighborhoods which may be candidates for general revitalization and in distressed 
neighborhoods. There are many ways in which their efforts can generate activity which can lead to revitalization. Creating things such as neighborhood festivals may seem trivial, but making neighborhoods more appealing often results in attracting more diverse economic groups (VonHoffman, 2004). Generating activism, itself, has a high correlation with the first wave of gentrification (VonHoffman, 2004), which amounts to a desirable influx of support for neighborhoods looking to revitalize. Hired activists could encourage small business ownership in the neighborhoods, perhaps funded through loans coming from the 100-million-dollar reserve this plan proposes (and other funding sources), with low-interest incentives. Certainly, there may be more limitations to small business success in distressed neighborhoods (Porter, 1997). However, creative measures can be taken to determine which businesses may succeed in the neighborhood. These might be grocery stores, for example, as even the poor must buy groceries, with programs like SNAP helping residents with affordability issues (Shaeffer and Gutierrez, 2013). Wilson argues that one struggle for distressed neighborhoods is that they cannot retain successful residents, who exit the neighborhood upon achieving upward mobility (Wilson, 1987). In a revitalizing neighborhood with a heavy activist effort, it is possible that residents who achieve upward mobility may feel some pride in being part of rebuilding their neighborhood. As a result, they may be more reluctant to leave the neighborhood behind, strengthening the possibility of a distressed neighborhood achieving mixed income (Drukker and Kaplan, 2005).

Obviously, much of what this plan needs to address is regeneration of small local businesses, in order to provide the access to employment and consumer goods for which this dissertation advocates (Arnold, 2010). The struggle for small businesses to succeed 
is a problem which goes well beyond the spatial issues addressed by this study. The failure rate of small businesses increased by 40 percent between 2006 and 2010 (Blakely and Leigh, 2013). Much of this failure is a result of ever-increasing levels of corporate control, which affects not only local businesses, but also gains from employment. The share of national income going to wages and salaries fell below 50 percent for the first time in 2010 (Norris, 2011).

These proposed advocacy groups would pursue strategies which promote urban development that counteracts this climate which is unfriendly to small business. It is typical for local governments to rely primarily upon tax abatement and tax increment financing to pursue local economic development (Koven and Lyons, 2005). However, some scholarship has identified places where policy is trending more towards progressive local economic development policy. Morgan's research identifies communities which seek to serve the broader public interest, benefit disadvantaged communities, and ensure accountability (Morgan, 2009). Such strategies are pursued through policies such as impact fees, requirements for hiring local residents, using minority-owned firms, and business performance guarantees (Morgan, 2009). The presence of strong neighborhood advocates and urban coalitions could pressure local governments to pursue such policies. Targeting progressive local development policies is crucial in allowing urban neighborhoods to thrive. But this specificity has often eluded economic development policy for local governments. Rubin (1988) long ago claimed that local economic development policy was akin to indiscriminate duck hunting, arguing that local governments shoot anything that flies and claim anything that falls to the ground. Louisville may be particularly de-incentivized from pursuing urban core development, 
given the nature of its consolidated city-county. Research suggests that the primary goal of local government is to expand their tax base (Kantor, 1995 and Morgan, 2009), meaning the urban-suburban dichotomy of local development could be blurred in a consolidated city-county. Thus, there may be less reason to focus upon the urban core, when suburban areas may be under the same tent. Admittedly, some research has revealed that city-county consolidation has jumpstarted urban development, but this is more in the form of corporatized urban renewal than neighborhood revitalization (Crooks, 2004). One of the many roles of these proposed advocacy groups and coalitions would be to fight off such indiscriminate development practices.

On the whole, it is unclear how the typical practices of local governments have benefited the majority of their residents. Enrich argues that giving money to large white collar corporations is the modern version of smokestack-chasing, doling out subsidies with questionable welfare benefits (Enrich, 1996). True interest in public welfare would involve attracting small firms, which are more likely to be attached to their region, thus limiting disinvestment (Schragger, 2011). The advocacy groups and urban coalitions proposed in this chapter would work to fight for more egalitarian local development policy, geared towards small business.

There is great capacity for a proposal such as this to influence the local and state governments in a fashion which can help to revitalize neighborhoods, and the urban core in general-- it has long been noted that there is a heavy correlation between neighborhood involvement and voting (Bailey Jr., 1974). A galvanized voting base may be able to heavily influence government leaders to make urban-oriented decisions. For example, in Louisville, former Kentucky Governor Steve Beshear and Mayor Greg Fischer celebrated 
the hundreds of jobs created by the 2015 opening of a Teleperformance call center in suburban eastern Jefferson County (Louisville Metro Government, 2015). This area is a low poverty part of the county (United States Census Bureau, 2010), located about a dozen miles from the urban core. This job facility offers easy-to-obtain unskilled labor, along with wages of twelve dollars and hour, and full-time employment. This work could be argued to be quite a find in today's economy, given the scant opportunity for entrylevel, living wage, full-time employment (Zuckerman, 2014). Spatially, there is no logical reason for such a facility to be located in affluent suburbs on the county periphery. It would make more sense to be located downtown, closer to the poor areas of the urban core. Such a location would allow the job site to be easily accessed by the eager, hungry employment base of these urban neighborhoods (Wilson, 1996). Any argument that the business needs to be located near an affluent customer base to support sales would not apply, as there are no on-site purchases.

If these neighborhood groups are able to form an urban coalition, they can potentially put activist and voting pressure upon leading public officials. The coalition could implore the local government to do things such as offer attractive subsidies to bring opportunity (like Teleperformance) to the urban core (Bingham and Zhang, 2001). These advocacy groups can also work to create a voice in decisions, such as the recent construction of a bridge in northeast Jefferson County. This bridge furthers pulls development away from the urban core, serving as another example of the type of regional development policies which these urban coalitions must combat.

It is possible that one positive side effect of the creation of strong urban coalitions would be an impact upon political issues at the national level, as well (as metropolitan 
coalition building impacts national elections, see Dreier et al., 2014). In the aftermath of the 2016 presidential election, there are many different reasons which political analysts point to as to why Hillary Clinton lost the electoral college to Donald Trump, losing several key states by narrow margins in the process. One observation is that if Clinton had done more to turn out struggling urban residents in large population centers, such as Philadelphia, Detroit, and Milwaukee, there might have been an impact on the outcome in their corresponding states (Jackson, 2016). As stated in the literature review, a byproduct of community involvement is increased involvement in voting (Hays and Kogl, 2000). In an election such as 2016, influencing the outcome of the presidential election could greatly impact issues such as healthcare and aggressive policing in urban neighborhoods (Habercorn, 2016 and Nelson, 2016). These sorts of issues can have great impact upon the resources and resilience of the residents in these areas (Wacquant, 2002, and Dreier et al., 2014), so increased voting at the national level will only aid neighborhoods in the revitalization process.

These hired activists could come from planning, public administration, political science, or perhaps other fields. Increasing the role of advocacy in planning has long been a goal in urban circles, primarily due to the introduction of advocacy planning by Paul Davidoff in 1965. The ideas of this chapter offer an alternative to what is traditionally offered through planning commissions and local public policy. This alternative can create a fleet of viable jobs in advocacy planning, spawning debate and pluralism in planning, and the competition with local planning commissions which Davidoff had envisioned (Davidoff, 1965). In addition to educated professionals, people identified in these cities as informally demonstrating the capacity for neighborhood- 
building could potentially be sought after for employment, as well. These sort of informal qualifications are seen in neighborhoods such as Clifton, with volunteer residents leading neighborhood activism. There have been actual rubrics created for the purposes of measuring activist acumen, evaluating experience for things such as public speeches, canvassing door-to-door, and writing letters-to-the-editor (Schutt, 2001).

Recalling the literature review in Chapter III of this dissertation, James DeFillipis argued that the largest problem which grassroots activism has encountered was its inability to connect to the larger political economy (DeFillipis, 2001). Creating widespread neighborhood and urban coalitions go a long way towards addressing the concerns of DeFillipis. These proposed neighborhood and urban coalitions could be seen in a similar fashion as labor unions. Essentially, these organizations function as unions protecting urban residents and urban areas from the self-interested behavior of local governments and business elites. Such coalitions can also be seen as a spatial version of the redistribution which Paul Peterson calls for in City Limits. Peterson (1981) argues that redistribution must come from the federal government rather than the local government, because local governments must pursue developmental policies to bring growth and jobs to the city. In this proposal, rather than redistributing income, the federal government would be redistributing power. This would be done through placing some of the power back in the hands of urban residents, rather than local elites. These organizations would also challenge the limitations which Peterson (1981) insists exists in cities, regarding only pursuing developmental policies. Peterson's assertion assumes that developmental policy is highly correlated with earning votes. If strong urban coalitions disrupt the calculus of such a premise, local government officials may have to think twice about 
simply serving the interests of the elite. Failing to address the interests of a strong urban coalition may ultimately result in them no longer remaining in office (Yin, 2001).

\section{Proposed Plan's Relationship with Existing Research}

Other scholars have also noted the need for community-based programs to attract more resources. In one prominent example, Stoecker has noted that community development corporations (CDCs) have been severely undercapitalized, struggling to keep up with the accelerating decay of the communities which they service (Stoecker, 1997). In addition to the lack of resources, Stoecker has been troubled by other aspects of CDC implementation, as well. He argues that the resource base for CDCs are controlled outside of the neighborhood, limiting community control and delegitimizing empowerment-oriented community organizing efforts (Stoecker, 1997).

At times, getting outside help in attracting resources can allow CDCs to be more effective. Stoecker points to Cedar-Riverside in Minneapolis as an example. In CedarRiverside, enormous resources were attracted by a Project Area Committee, while the local CDC was able to focus upon community organizing (Stoecker, 1997). This shift is in contrast to what has been argued by some proponents of corporate-based CDCs, who argue that the poor do not have the time, the interest, or the skills to participate in community-based CDCs (Stoecker, 1997).

In the larger American landscape, Stoecker believes that the CDC can have much a more powerful role than what has traditionally been the case. He points to socially democratic European countries like Sweden and the Netherlands, where CDCs produce 55 and 35 percent of the housing nationally, respectively (Stoecker, 1997). Stoecker supports cases where the American federal government is willing to spend significant 
amounts of money on CDCs, especially those in which the government is willing to invest in excess of ten million dollars per neighborhood (Stoecker, 1997).

Stoecker has further noted that in turning the attention of community groups towards activism and organization, a challenge becomes the problem of activists and nonactivists being grouped together within these communities (Stoecker, 1995). Stoecker argues that a common bond is often necessary to get community organization moving forward. He points to East Toledo, which was composed of a variety of ethnic groups such as Slovaks, Hungarians, African-Americans and Latinos, who embraced this diversity and formed a community organization around preserving this identity (Stoecker, 1995). One of the signature achievements of this group was the creation of the Birmingham Ethnic Festival, one of the largest festivals in Toledo, which greatly increased the political capital of the organization (Stoecker, 1995). The impact of this festival demonstrates how seemingly minor developments in a community can potentially shift its trajectory in terms of political and economic standing. This point bolsters the argument of this chapter that putting boots on the ground in neighborhoods merits serious consideration as a primary urban policy.

An Alinsky-style organization known as ETCO formed in this Toledo neighborhood, with some residents concerned that its tactics were too confrontational (Stoecker, 1995). Initially, this group would fight for social needs such as relocations benefits, due to the neighborhood trailer park being located near a toxic waste dump (Stoecker, 1995). During the 1980s, this organization moved towards a more neoliberal focus, instead working on things like housing rehabilitation assistance and creating job 
banks (Stoecker, 1995). Stoecker bemoans this transformation as part of a larger trend of community organizations losing their activist edge and political teeth (Stoecker, 1995).

Clavell, Pitt and Yin joined Stoecker in arguing that community groups need to be given more power in the American political economy. They argue that community-based efforts should be a primary consideration for both local and national urban policy (Clavel, Pitt, and Yin, 1997). They further argue that grassroots efforts could present a possible new reality to urban scholars and professionals, in the face of the growth-oriented and top-down approaches which dominate urban policy (Clavel et al., 1997). There have been significant efforts, in the past, to give neighborhood groups a more dominant role in urban politics. In the late 1970s, the active political climate throughout the neighborhoods of Cleveland led to the election of populist mayor Dennis Kucinich (Yin, 2001). Kucinich won by running on such community-based issues as saving the municipally-owned power company (Yin, 2001). On the whole, however, Kucinich was ultimately unable to push across the progressive agenda needed to satisfy his communityactivist base (Clavel, 1986). Nonetheless, scholars continue to argue that communities need to be given a strong voice in urban politics. DeFillipis shares this view, arguing that the centralized nature of city governments leads to a disconnection from the needs of citizens across various neighborhoods, and that community control is the only way to address social needs (DeFillipis, 2004).

There are parallels between the strategies proposed in this chapter and the arguments of these scholars, particularly Stoecker. Certainly, Stoecker’s (1997) argument that massive amounts of resources, in the form of the tens of millions of dollars per neighborhood, need to be poured into CDCs, is indicative of how he wants to see 
national urban policy be much more robust in cultivating community development. This sentiment is consistent with this proposal's call for widespread urban and neighborhood advocacy groups to become a potentially national urban policy. Additionally, Stoecker's concerns that community development has taken a more neoliberal turn, away from activism and engagement, are consistent with the call for unceasing activism across America's urban neighborhoods called for by my proposal.

Stoecker’s (1997) focus upon the undercapitalization of community groups, specifically CDCs, is where his work and my proposal differ, however. This chapter has highlighted the concern that through programs such as Hope VI or Choice Neighborhoods, which focus heavily upon design, that resources are drained into what essentially operate as model neighborhoods. To go too far in heavily financing individual neighborhoods through a community development paradigm could result in a model neighborhood phenomenon, as well. The proposal presented in this chapter is one which hopes to test the sustainability of urban regeneration efforts across all urban neighborhoods. Thus, while monetary resources are certainly part of the plan, the primary purpose of these resources is to provide constant manpower. As Speer and Hughes (1995) argue, the largest obstacle to community organizations being successful is their inability to maintain constant participation. It is the argument of this proposal that transferring resources from money to manpower can potentially spread these resources much further, when trying to address urban regeneration nationally (as well as within each individual metropolitan area). 


\section{Concluding Thoughts on Federally-Funded Urban Advocacy}

The exact figures, budget, and expenditures for this program can be slightly modified if needed. The numbers used in this chapter are primarily to illustrate the economic feasibility of this strategy. Given the conceptual nature of this strategy, it is not really possible to offer specific projections as to what the total impact of these suggestions will be. Mainly, this chapter tries to make a compelling argument that such policies can have a significant and comprehensive impact upon revitalizing American cities. Urban neighborhoods would be revitalized in the process, greatly impacting spatial social equity. It is important to remember that the launch of New Urbanism as a movement was largely experimental in nature. Yet it continues to be a source of vast promotion and development, with little evidence that its progressive promises have been achieved. Additionally, it has become a go-to development style for HUD, attracting massive amounts of public and private funds in the process (Cisneros, 2009). It is challenging to argue that these Hope VI/Choice Neighborhoods communities have the capacity to impact the spatial social equity of cities to the degree that the program recommended in this chapter does. If there is hesitancy from policy-makers to pursue experimental strategies, it would be possible to begin by just testing out this proposed program on one city. However, to give an experimental city a chance to succeed means an all-in, long-term commitment to that particular city. Again, the creation of one of these city-wide programs would require only a very small fraction of HUD’s budget (HUD, 2016), so its compelling arguments regarding urban regeneration should be considered. 
One criticism of this program could be the concern that it would work too well. There are potential downsides to a city's urban core becoming revitalized to the point that the city becomes a highly-desirable destination. Cities like New York, San Francisco, and Washington, D.C. have experienced gentrification to the point that housing has become unaffordable (Freeman and Braconi, 2004; Smith, 2007; Hyra and Prince, 2016). However, it may be overstating the potential of this strategy to say that the impact will be this resounding. Though I would argue that the impact can indeed be substantial. Hypothetically, if this movement did achieve an exorbitant level of success, it is possible that a principle introduced in Talen's (2010) New Urbanism research could save cities from becoming unaffordable: Talen argues that one way for New Urban communities to lower the cost of their housing would be for to developers to flood the market with NU communities. This practice would expand the supply, while lowering the market rate in the process (Talen, 2010). Similarly, if the strategies discussed in this chapter are so successful that major concerns over gentrification occur, it is helpful to remember that this program is proposed as a nationwide urban policy. Thus, if one city reached such a level of desirability, it is quite possible that many others could as well. Ultimately, it would become the norm for American residents to live in cities with vital urban cores, which could address some of the supply issues which make living in one city more expensive than another. After all, Guyorko, Mayer, and Sanai (2013) have illustrated the connection between supply and high cost of living in cities.

In short, the focal point of this program is the organized infusion of urban advocates, en masse across American cities, funded by the federal government. Again, there is the possibility of starting with one city and testing the program, as long as there is 
a willingness to commit to the program for an extended period of time, and hire these advocates for urban neighborhoods throughout the entire city. The specific needs of the urban area or city in question can vary greatly, so the precise focus of the advocates will depend on the situation. It may be the case that there is history to a particular neighborhood, and various amenities which have fallen out of use possess a certain character which may be attractive to consumers (VonHoffman, 2004). In such a case, the urban advocate working on such a neighborhood, in working with the larger urban coalition, may identify that such an area is ripe for revitalization. Such a neighborhood may qualify as an opportunity for the "general urban revitalization" characterized earlier in this chapter. The assigned advocate might identify historic preservation, aiding in the marketing of local businesses and other strategies as appropriate for this neighborhood. Working towards revitalizing the neighborhood would potentially contribute towards the revitalization of the urban core as a whole. Alternately, an advocate may work for a distressed neighborhood, characterized as poverty-concentrated. This advocate may work on things such as fighting for regulations on nearby power plants, which negatively impact the neighborhoods air and environmental quality, or pushing for voter participation so that the neighborhood's needs will be more strongly considered in city politics. These aforementioned examples are a small sample of the various goals an advocate could establish, depending upon the neighborhood. While these needs will vary, the central point of this plan is to create a system by which there are always people working on these things, whatever they may be.

With the creation of the neighborhood activist groups, it may be possible to create citywide urban coalitions. These coalitions can fight for policies which may be citywide 
in nature, which will help to revitalize the urban core. Previous attempts to connect federal funding to community control have missed the boat. Clinton's Empowerment Zone Program sought to provide federal funding for neighborhoods which could present compelling mission statements to the government (McFarlane, 2000). The plan ultimately failed, because distressed neighborhoods often did not possess residents with the skills necessary to present the applications effectively to the federal government (McFarlane, 2000). The plan offered by this chapter assures that someone will always be there in a neighborhood to articulate the community's needs. The constancy of this presence is, in many ways, one of the key components of this plan. This constancy allows for neighborhood advocacy to survive the waxing and waning fortitude which may otherwise be a part of neighborhood organizations (Speer and Hughes, 1995). Again, DeFillipis, Fisher and Schragge (2010) argue that the key to success of community organizations is for them to be sustained over time, for advocates to politically-educated, and to have the ability to connect to larger social movements. The permanence, training, and coalition-building behind this proposed advocacy takes all three of these requirements into account.

The anticipated result of such a program would be a regenerated urban core, or at least one which is further in the direction of regeneration. Revitalizing business in the urban core potentially creates both job opportunity and consumer access within the neighborhood. The results of this dissertation, presented in earlier chapters, demonstrate how New Urbanism does not appear to have the same potential to produce such amenities as does revitalization of the existing urban core (Bingham and Zhang, 2001). These results also demonstrate how a regenerated urban neighborhood may be more likely than 
a New Urban community to help the low-mobility residents who particularly need access to these amenities, both within the neighborhood, and through a stronger relationship with the city and region’s public transit system.

Amongst the stated goals of New Urbanism, through the Ahwahnee Principles, are many goals relating to spatial social equity: access to employment and consumer goods for all income groups; access to transit; and mixed-income housing, all within walking distance of the same neighborhood (Fulton, 1996). Scholars continue to defend New Urbanism's potential to achieve such goals (Trudeau and Kaplan, 2015). The findings of this study, with Norton Commons representing the prototypical New Urban neighborhood, suggest there may be better ways to promote spatial social equity when addressing urban decimation. Clifton's stronger performance with the social equity criteria of this study offers a glimpse at how spatial social equity may be achieved through revitalizing existing urban areas. The proposal of this chapter offers a potential road map for how this might be done, through federally-sponsored grassroots community efforts.

Certainly, implementation of the policies proposed in this chapter would require a very progressive federal government to back them. This political composition is something which is far from existing in the United States, at the moment, with Republicans controlling the executive branch, as well as both congressional houses. Nonetheless, it is the primary aim of this chapter to advocate for policies which, if implemented, would stand the greatest chance for success in revitalizing urban areas and improving spatial social equity. It could be the case that those in power, regardless of 
administration, are perfectly satisfied dedicating large amounts of federal money to programs which promise limited impact. Such a dynamic would allow high-ranking government officials to claim to their constituencies that real urban concerns are being taken seriously, all the while making sure not to disrupt the power structure in the process. However, the recommendations of this chapter are based upon the assumption that urban policy makers truly do want to want to achieve meaningful results. If this is not the case, then any policy recommendation regarding spatial social equity is rendered meaningless.

This chapter attempts to offer effective methods for addressing spatial social equity and urban revitalization. It does so through arguing for extensive, city-wide neighborhood advocacy networks, funded by the federal government. The final and following chapter, Chapter X, will offer a synthesis and summary of the work and contents of this study. In doing so, it will review the premise, literature, findings, and policy implications which comprise this dissertation. 


\section{CHAPTER X}

\section{CONCLUSIONS}

It has been the aim of this dissertation to take a comprehensive, micro-level look at a prototypical New Urban neighborhood, in Louisville’s Norton Commons, through comparing it to a viable urban neighborhood in Louisville, in Clifton. In doing so, the goal is to gain some insight into which construct is more likely to support spatial social equity. In the process, this dissertation has: 1) highlighted New Urbanism's intended commitment to social equity, 2) investigated the intersection between the literature on New Urbanism and social equity, as well as the literature on how neighborhood revitalization is achieved through grassroots means, 3) empirically highlighted the ways in which Norton Commons does not match up with Clifton in terms of addressing spatial social equity, and speculated as to what this may mean for New Urbanism on the whole, 4) highlighted some of the challenges to simply tweaking New Urbanism, rather than developing a new strategy for urban revitalization and spatial social equity, and 5) explained how it may be possible to meaningfully pursue neighborhood and urban revitalization through strong grassroots coalitions, in an effort to create spatial social equity.

The literature has established that along with its mixed-use design, which strives for mixed income and transit orientation, proponents of New Urbanism have attempted to sell it as a vehicle for addressing social equity. This stance is evidenced by its principles, 
founders, and congressional body (Duany et al., 1991 and 2000; Congress for the New Urbanism, 1996 and 2008). Additionally, the movement's commitment to inclusiveness and affordability is noted by scholars (MacLeod, 2013). Considerable questions have been raised by scholars as to the degree which New Urbanism has met certain goals which would advance social equity in a spatial sense, such as affordability (Irazabal, 2012). Additionally, there are questions as to whether the regional location is consistent with transit access and if there are effective retail presences in New Urban neighborhoods (Fulton, 1996).

In addition, the literature has shown that grassroots neighborhood revitalization is a process which can potentially help create areas which lead to spatial social equity. Access to consumer goods and employment are potentially improved in the process, through enhancing business presence. Grassroots neighborhood revitalization typically occurs either through existing residents working to improve a neighborhood, bohemian outsiders moving into the neighborhood and catalyzing changes, or outside professional activists or organizations stepping in to create neighborhood organizations. Existing residents have revitalized neighborhoods in major cities such as New York and Boston, amongst others. They have done so by creating makeshift gardens (Talen, 1999), community development corporations (Boyte, 1980) and giving their communities having a voice in local politics (Hays and Kogl, 2007).

Though there is sometimes the risk of gentrification, bohemian outsiders bring a welcome initial wave of revitalization to neighborhoods. They flock to these areas due to their attraction to locations near downtown, old-fashioned buildings, and cultural amenities (Ley, 1996). Revitalization occurring through the presence of outside activists 
and organizations initially began in the form of Alinsky-style organizations. These organizations relied heavily upon protest as a resource (Alinsky, 1971) and have recently progressed towards teaching residents general neighborhood organizational skills (Peterman, 2000). The challenge with grassroots neighborhood organization, in general, is its ability to connect to the larger political economy. There have been few periods in American history where nationwide gains have been experienced from grassroots movements (DeFillipis, 2001).

The potential for social equity for each neighborhood was evaluated through many indicators by this study. The findings speak to the potential larger phenomena which each neighborhood represents: vibrant urban neighborhoods, revitalized through grassroots activism, in the case of Clifton; as well as the prototypical affluent suburban New Urban neighborhood, in the case of Norton Commons. At the neighborhood and inter-neighborhood levels, these elements of spatial social equity are captured by the Ahwahnee Principles which New Urbanism strives to meet. Looking at the neighborhoods themselves, Clifton has significantly more affordable housing, access to unskilled employment opportunity, access to consumer goods for daily needs, and access to public transit than does Norton Commons. Meanwhile Norton Commons is comparable to Clifton in terms of lower priority principles, such as recreational amenities and walk-able sidewalk design. Clifton is able to benefit from its nearby areas more so than Norton Commons, through unskilled job opportunity, transit access, recreational amenities, and walk-able conditions, among other indicators. This benefit is largely a function of urban neighborhoods being able to blend together, while New Urban neighborhoods typically make little effort to take surrounding areas into account during 
the development process (Talen, 1999). Regionally, low-mobility residents from the urban core are much more easily able to access Clifton through public transit than Norton Commons. Likewise, low-mobility residents in Clifton are more easily able to access major regional unskilled labor facilities through public transit than is the case for Norton Commons, though this lack of access to unskilled labor facilities for Norton Commons may improve if public transit begins to cross the region’s I-265 bridge. Within a short transit range of the neighborhood, Clifton has a wide variety of economic groups, including many impoverished areas which can access the neighborhood. Conversely, much of the areas within this range for Norton Commons are among the most affluent in Louisville's metropolitan area.

These observations do not offer potential solutions, but certainly highlight a problem. It is not necessarily a binary choice as to whether to pursue New Urbanism or grassroots urban revitalization. However, there are limited resources for progressive goals, and misguided strategies can often consume too much of the focus of those pursuing equitable urban development. Additionally, given that each strategy deals directly with reversing the forces of urban decimation, it is of great use to get a sense of which strategy may be more effective.

In comparing these findings to a general synthesis of the literature on New Urbanism, there is much reason to believe that the challenges seen in this study for Norton Commons may be seen in most private New Urban communities. This dissertation has argued that due to the progressive proclamations that declare NU a movement for social equity (Duany et al., 2000 and CNU, 2016), that it is not enough for New Urban communities to simply be desirable communities for the affluent. 
It is unclear how New Urbanism will untangle its logic to reach a point where it resembles the progressive goals it espouses. One of the founders of the movement, Andres Duany, argues that the only known technique for keeping housing affordable is bad design (Walker, 2002). Thus, it is implied that any development, New Urbanist or otherwise, will not be seen as a success unless its prices rise. It may indeed be the case, through gentrification, or high property values in general, that the premise of Duany's argument is correct. But it also seems to concede that it would be challenging to argue that a design movement could create mixed-income housing.

Advocates of New Urbanism suggest that they offer physical design concepts to facilitate environmentally responsible developments (Kellbaugh, 2002). Though this study focuses upon social equity, it is important to understand whether or not New Urbanism can impact the environment. Environmental impact could potentially be used to excuse the movement's lack of social impact. There is little in the composition of metropolitan areas to suggest that New Urbanism is on track to radically impact public transit use. Sustainable growth is often the paradigm for many comprehensive plans (Berke and Conroy, 2000), but it is argued that the idea New Urbanism can have any impact on suburban sprawl development is unlikely (Garde, 2004).

Louisville’s Park DuValle has frequently been lauded as a success story for Hope VI New Urbanism. Certainly, early research suggested that Park DuValle may serve as an example of how New Urbanism can achieve income-mixing through Hope VI. The neighborhood was found to have 43 percent of its household with incomes less than 80 percent of local median income, 27 percent with incomes between 80 and 115 percent of local median income, and 30 percent with incomes above 115 percent local median 
income (Turbov and Piper, 2002). This distribution is reasonably even across incomelevels.

However, this dissertation argues that trying to fix New Urbanism by focusing primarily upon creating urban NU communities through HUD is an unsatisfactory answer. Not only is it debatable as to whether there is significant impact upon social equity in these communities, but the enormous funding required calls into question whether other methods might spread these dollars further, in addressing social equity. Finally, it is argued that merging New Urbanism with another debatable urban strategy, in dispersal, to bring more low-income housing into affluent, suburban NU communities will not be effective. This lack of effectiveness is partially due to how inaccessible to transit, employment, and essential daily goods such New Urban communities are.

New Urban principles ultimately became the model for Hope VI construction (Bohl, 2000). In addition to the sites of Hope VI construction themselves, hope was that providing housing vouchers for low-income residents exiting the areas would spur new construction for affordable housing (Wexler, 2001). But questions remain as to what happens to these departing residents (Popkin et al., 2004). To the extent to which Hope VI New Urban communities can theoretically have a positive impact, this dissertation raises major questions regarding how expansive the strategy can be, given the price tag. Ultimately, there has typically been insufficient funds to meet the level of demand for such communities (Levy, 2004).

This dissertation concludes by arguing that the spatial social equity seen in Clifton, an urban neighborhood with a grassroots activist presence, needs to be replicated as often as possible. In the case of highly-distressed neighborhoods, in the least, 
measures need to be taken to move further in this direction. These measures should happen on a city-wide level, by reallocating misused federal funds towards hiring advocacy planners and urban advocates in general. These advocates would be dispersed throughout the urban core of mid-sized cities. Their work would be to diligently focus upon creating active neighborhood organizations, identify the possibilities for revitalization within urban neighborhoods, and to go to bat with local political and business elites to get policies which benefit these neighborhoods.

These advocacy networks and coalitions will allow for urban neighborhoods to combat negligent or oppressive local governments. Local development scholars have found social equity to be far down on the priority list for local governments (Morgan, 2009). Additionally, due to focus upon export production and growth (North, 1955), small business has long been left out of local economic development strategy. Grassroots urban regeneration can potentially spur such a business presence, which in turn would promote consumer and employment access to diverse income groups, in centralized, urban locations.

It is this comprehensive, on-the-ground focus which gives this strategy promise. These methods are certainly preferable to the creation of expensive, fancy, gimmick neighborhoods, as happens through New Urbanism. These misguided New Urban developments occur through both private developers in affluent suburbs, and through bloated federal government spending on HUD’s New Urban communities. The centerorientation of this dissertation's policy recommendations are innately geared towards spatial social equity. There would also be a diverse economic base to be served which may not exist with the highly-mobile customer base of affluent, suburban New Urban 
communities (who may not need such intervention). All that remains is to advance the strength of business in urban neighborhoods, providing access to consumer goods and employment in the process. While there may be mixed results, the potential for creating socially equitable environments is there, with the aid of focused and extensive, but quite feasible, urban activism. 


\section{REFERENCES}

ACORN. 2002. “Accomplishments”. American Community Organizations for Reform Now. Retrieved July 20, 2017, from acorn.org.

Alinsky, S. 1971. Rules or Radicals: A Practical Primer for Realistic Radicals. New York: Random House.

Alperovitz, G. 2004. America Beyond Capitalism: Reclaiming Our Wealth, Our Liberty, and Our Democracy. Hoboken, New Jersey: John Wiley \& Sons.

American Planning Association. 2014. “2014 Salary Survey Summary”. Retrieved July 14, 2017, from planning.org.

Arnold, J. 2010. "Recession to Regeneration: The Importance of Community Renewal in Current Economic Circumstances.” Center for Local Economic Strategies. Manchester, England.

Bailey Jr., Robert. 1974. Radicals in Urban Politics. Chicago: University of Chicago Press.

Benjamin, L., Rubin, J., and Zulenbach, S. 2004. "Community Development Financial Institutions.” Journal of Urban Affairs, 26(2), pp. 177-195.

Berke, P. and Conroy, M. 2000. “Are we Planning for Sustainable Development?” Journal of American Planning Association, (66)1, pp.21-23.

Bernick, M. and Cervero, R. 1997. Transit Villages in the $21^{\text {st }}$ Century. New York: McGraw-Hill Publishing.

Berube, A. and Katz, B. 2005. “Louisville and New Orleans.” Washington, D.C.: Brookings Institute.

Bingham, R. and Zhang, Z. 2001. The Economies of Central-City Neighborhoods. Boulder: Westview Press.

Blakely, E. and Leigh, N. 2013. Planning and Local Development: Theory and Practice. Los Angeles: Sage Publications.

Bieto, D. 2000. From Mutual Aid to the Welfare State: Fraternal Societies and Social Services, 1940-1967. Chapel Hill, North Carolina: University of North Carolina Press. 
Bohl, C. 2000. "New Urbanism and the City: Potential Applications and Implications for Distressed Inner-City Neighborhoods.” Housing Policy Debate, 11(4), pp. 761-801.

Bordieau, P. 1985. “The Forms of Capital.” Handbook of Theory and Research for the Sociology of Education. Greenwood Press: New York.

Boyte, H. 1980. The Backyard Revolution: Understanding the New Citizen Movement. Philadelphia: Temple University Press.

Boyte, H. 2004. Everyday Politics: Reconnecting Citizens and Public Life. Lawrence, Kansas: University of Kansas Press.

Bray, P. 1993. “New Urbanism: Celebrating the City.” Places, 8(4), pp. 56-65.

Briggs, X. 2005. “The Geography of Opportunity: Race and Housing Choice in Metropolitan America”. Washington, D.C.: Brookings Institute.

Buntin, J. 2015. “The Myth of Gentrification”. Slate. New York.

Burns, P. 2007. "Community Organizing in a Non-regime City: The New Orleans Experience.” In Orr, M. (ed.), Transforming the City: Community Organizing and the Challenge of Political Change. Lawrence, Kansas: University Press of Kansas.

Cavenaugh, G. 1992. “To Whom Should Limited Housing Resources be Directed?” Housing Policy Debate, 3(1), pp. 1-40.

Center for Neighborhoods. 2015. Retrieved January 11, 2017, from: www.centerforneighorhoods.org. Louisville, Kentucky.

Chan, E. and Lee, G. 2008. "Critical Factors for Improving Social Sustainability of Urban Renewal Projects.” Sustainability, 16, 353-364.

Chaskin, R. and Joseph, M. 2015. "Contested Space: Design Principles and Regulatory Regimes in Mixed-Income Communities in Chicago.” Annals of the American Academy of Political and Social Science, 660 (1), pp. 136-154.

Cisneros, H. 2009. “A New Moment for People and Cities.” In Cisneros, H. and Engdahl, L. (eds.), From Despair to Hope: Hope VI and the New Promise of Public Housing in America's Cities, pp. 3-14. Washington, D.C.: Brookings Institution Press: Washington, D.C.

Clavell, P. 1986. The Progressive City. New Brunswick, New Jersey: Rutgers University Press. 
Clavell, P., Pitt, J., and Yin, J. 1997. “The Community Option in Urban Policy.” Urban Affairs Review, 3(24), pp. 435-458.

Clifton Community Council. 2014. “Meeting Minutes, 2013-2014.” Louisville, Kentucky.

Cloward, R. and Piven, F. 1999. “Disruptive Dissensus.” In Rothman, J. (ed.), Reflections on Community Organizing. Belmont, CA: Cengage Press.

Congress for the New Urbanism. 1996. Charter of New Urbanism. San Francisco.

Congress for the New Urbanism. 2008. "Canons of Sustainable Architecture and Urbanism: A Companion to the Charter of New Urbanism”. Austin, Texas.

Congress of New Urbanism. 2016. CNU.org. Washington, D.C.

Couch, L. 2015. “Public Housing: Choice Neighborhoods Initiative and Hope VI.” 2015 Advocates Guide. National Low-Income Housing Commission. Washington, D.C.

Crane, R. 1996. "Cars and Drivers in the New Suburbs: Linking Access to Travel in Neo-traditional planning.” Journal of American Planning Association, 62(1), pp. 51-65.

Crooks, J. 2004. Jacksonville: The Consolidation Story, from Civil Rights to the Jaguars. Gainesville, Florida: University of Florida Press.

Cuomo, A. 2015. “2014 Annual Report: Community Services Block Grant Program.” New York Department of State. Albany, New York.

Davidoff, P. 1965. “Advocacy and Pluralism in Planning.” Journal of the American Institute of Planners, 31(4), pp. 421-432.

Dear, M. 2007. "Understanding and Overcoming the 'NIMBY' Syndrome.” Journal of the American Planning Association, 58(3), pp. 288-300.

DeFillipis, J. 2001. “The Myth of Social Capital in Community Development.” Housing Policy Debate, 12(4), pp. 781-806.

DeFillipis, J. 2004. Unmaking Goliath: Community Control in the Face of Global Capital. New York: Routledge Press.

DeFillipis, J., Fisher, R., and Schragge, E. 2010. Contesting Community: The Limits and Potential of Local Organizing. New Brunswick, New Jersey: Rutgers University Press. 
DeFillipis, J. and Fraser, J. 2010. “Why do we want Mixed-Income Neighborhoods?” In Davies, J. and Imbroscio, D. (eds.) Critical Urban Studies: New Directions (pp. 135-148). Albany, New York: State University of New York Press.

Dempsey, N. 2009. "Are Good Quality Environments Socially Cohesive? Measuring Quality and Cohesion in Urban Neighborhoods?” The Town Planning Review, 80(3), 315-345.

Dempsey, N., Bramley, G., and Power, S. 2009. "The Social Dimension of Sustainable Development: Defining Urban Social Sustainability.” Sustainable Development, 19(5), pp. 289-300.

Derienzo, H. 2007. “Rebuilding Community.” National Civic Review, 96(3), pp. 16-26.

Dreier, P., Mollenkopf, J., and Swanstrom, T. 2014. Place Matters: Metropolitics for the Twenty-First Century ( $3^{\text {rd }}$ ed.). Lawrence, Kansas: University of Kansas Press.

Drukker, M. and Kaplan, C. 2005. "Residential Instability in Economically Deprived Neighborhoods”. Health \& Place, 11(2), pp. 121-129.

DSNI. 2015. “Dudley Street Initiative.” Boston. From: www.dnsi.org.

DSNI. 2002. “The Boston Foundation Persistent Poverty Project Records.” Dudley Street Neighborhood Initiative Mission Statement. Boston.

Duany, A. and Plater-Zyberk, E. 1991. Town and Town Making Principles. New York: Rizoli Publishing.

Duany, A. and Plater-Zyberk, E. 1994. "The Neighborhood and the District.” In Katz, P. (ed.) The New Urbanism: Towards an Architecture of Community. New York: McGraw-Hill Education.

Duany, A.; Plater-Zyberk, E.; and Speck, J. 2000. Suburban Nation: The Rise of Sprawl and the Decline of the American Dream. New York: North Point Press.

Elliot, D.; Menard, S.; Rankin, B.; Elliot, A.; Wilson, W.; and Huizinga, D. 2006. Good Kids from Bad Neighborhoods. Boston: Cambridge University Press.

Ellis, C. 2002. “The New Urbanism: Critiques and Rebuttals.” Journal of Urban Design, 3(7), pp. 261-291.

Else, J. 2000. “Microenterprise Development in the U.S.” International Labor Office. Geneva, Switzerland. 
Engdahl, L. 2009. “An Overview of Hope VI Revitalization Grants.” In Cisneros, H. and Engdahl, L. (eds.), From Despair to Hope: Hope VI and the New Promise of Housing in America's Cities (pp. 121-144). Washington, D.C.: Brookings Institution Press.

Enrich, P. 1996. "Saving the States from Themselves: Commercial Clause Restraints on State Tax Incentives for Business.” Harvard Law Review, 110(2), pp. 377.398.

Entmacher, J.; Robbins, K.; Vogtman, J.; and Frohlich, L. 2014. "Insecure and Unequal: Poverty and Income among Women and Families, 2000-2012.” National Women's Law Center. Washington, D.C.

Eppli, M. and Tu, C. 1999. "Valuing the New Urbanism.” Real Estate Economics, 27(3), pp. 425-451.

Eppli, M. and Tu, C. 2014. "The Market Acceptance of Single-Family Housing Units in Smart Growth Communities.” Environmental Protection Agency. Washington, D.C.

Ewalt, P., Freeman, E., and Poole, D. 1998. Community Building: Renewal, Well-being, and Shared Responsibility. Washington, D.C.: NASW Press.

Ewing, R. and Hamidi, S. 2014. “Measuring Sprawl: 2014.” Washington, D.C.: Smart Growth America.

Farrell, M. 2009. "What is the ACORN Controversy About?” Christian Science Monitor. Boston.

Fischer, G. 2016. “Move Louisville: 2035 Transportation Plan.” Louisville Metro Government. Louisville, Kentucky.

Forester, J. 1984. "Bounded Rationality and the Politics of Muddling Through.” Public Administration Review 44, pp. 23-31.

Florida, R. 2002. The Rise of the Creative Class: And How It's Transforming our Work, Leisure, and Everyday Life. New York: Basic Books.

Freeman, L. and Braconi, F. 2004. "Gentrification and Displacement: New York City in the 1990s.” Journal of the American Planning Association, 70(1), pp. 39-52.

Fulton, W. 1996. The New Urbanism: Hope or Hype for American Communities. Lincoln Institute of Land Policy. Cambridge, Massachusetts.

Galbraith, J. 1983. The Anatomy of Power. Boston: Houghton Mifflin. 
Garde, A. 2004. “New Urbanism as Sustainable Growth”. Journal of Planning Education and Research 24, pp. 154-170.

Garr, E. and Kneebone, E. 2010. “The Suburbanization of Poverty.” Washington, D.C.: Brookings Institution.

Garr, R. 2017. “5 Great Neighborhoods in Louisville.” Great American Country. Retrieved May 22, 2017, from: greatamericancountry.com.

Gattis, T. (2008, July 14). "Why there aren’t more New Urban Developments.” The Houston Chronicle. Retrieved from: www.chron.com/news/Houston.

Gilderbloom, J. 2008. “Newport’s Hope VI Project Evaluation.” University of Louisville’s Center for Sustainable Neighborhoods. Louisville, Kentucky.

Gindin, S. 2002. "Social Justice and Globalization: Are they Compatible?.” Monthly Review, 54(2), pp. 1-23.

Gittell, R. and Vidal, A. 1998. Community Organizing, Building Social Capital as a Development Strategy. New York: Sage Publications.

Glaser, E. 2011. Triumph of the City: How Our Greatest Invention Makes Us Richer, Smarter, Healthier, Greener, and Happier. London: Penguin Press.

Grant, J. 2013. “The Future of the Suburbs: Suburbs in Transition.” Planning Theory and Practice, 13(3), pp. 391-415.

Gyourko, J.; Saiz, A.; and Summers, A. 2008. “A New Measure of the Local Regulatory Environment for Housing Markets: The Wharton Residential Land Use Regulatory Index.” Urban Studies, 45(3), pp. 1-58.

Gyourko, J.; Mayer, C.; and Sanai, T. 2013. “Superstar Cities.” American Economic Journal: Economic Policy, 5(4), pp. 67-99.

Habercorn, J. 2016, (November 9). “Trump Victory puts Obamacare Dismantling within Reach.” Politico. Retrieved from www.politico.com.

Hall, K. and Porterfield, G. 2001. Community by Design: New Urbanism for Suburbs and Small Communities. New York: McGraw- Hill Publishing.

Hanka, M. 2009. From Vice to Nice: A Case Study of Newport, Kentucky's Hope VI Program. University of Louisville Institutional Repository. Louisville, Kentucky. 
Hays, R. and Kogl, A. 2007. "Neighborhood Attachment, Social Capital Building, and Political Participation: A Case Study of Low and Moderate-Income Residents of Waterloo, Iowa.” Journal of Urban Affairs, 25(2), pp. 181-205.

Hartman, C.; Keating, D.; and LeGates, R. 1982. Displacement and How to Fight It. National Housing Project. Berkeley, California.

Heid, J. 2004. “Greenfield Development without Sprawl: The Role of Planned Communities.” Urban Land Institute. Washington, D.C.

Hobbs, F. and Stoops, N. 2002. "Demographic Trends in the $20^{\text {th }}$ Century." United States. Census Bureau 2000: United States Government Printing Office. Washington, D.C.

Hodson, R. and Sullivan, T. 2006. Social Organization of Work, (4 ${ }^{\text {th }}$ ed.). Boston: Wadsworth Publishing.

Holman, Nancy. 2007. "Following the Signs: Applying Urban Regime Analysis to a UK Case Study.” Journal of Urban Affairs, 29(5), pp. 435-453.

Hochschild, J. and Danielson, M. 1998. "Can we Desegregate Public Schools and Subsidized Housing? Lesson from Yonker’s New York.” In Stone, C. (ed.) Changing Urban Education. Lawrence, Kansas: University of Kansas Press.

Howard, E. 1902. Garden Cities of Tomorrow. London: Swan Sonnenschein and Company.

HUD. 2016. "HUD Resources.” United States Department of Housing and Urban Development. Washington, D.C.

Hyman, J. 2002. "Exploring Social Capital and Civic Engagement to Create a Framework for Community Building.” Applied Developmental Science, 6(2), pp. 196-202.

Hyra, D. 2013. "Causes and Consequences of Gentrification and the Future of Equitable Development Policy.” Cityscape: A Journal of Policy Debate and Research, 15(2), pp. 123-132.

Hyra, D. and Prince, S. Capital Dilemma: Growth and Inequality in Washington, D.C. London: Routledge Press.

Imbroscio, D. 2010. Urban America Reconsidered. Ithaca, New York: Cornell University Press. 
Imbroscio, D. 2016. “Urban Policy as Meritocracy: A Critique.” Journal of Urban Affairs, 38(1), pp.79-104.

Irazabal, Clara. 2012. “Beyond ‘Latino New Urbanism': Advocating Ethnurbanisms.” Journal of Urbanism, 5(2), pp. 241-268.

Jackson, K. 1985. Crabgrass Frontier: The Suburbanization of the United States. Oxford, England: Oxford University Press.

Jackson, N. (2016, November 15). “Trump’s Win isn’t all about White People: Clinton Lost Black and Brown Votes in Key States.” Huffington Post. Retrieved from: www.huffingtonpost.com.

Jacobs, J. 1961. Death and Life of Great American Cities. New York: Random House.

Jargowski, P. 1997. Poverty and Place. New York: Sage Publications.

Jargowski, P. 2013. "Concentration of Poverty in the New Millenium: Changes in the Prevalance, Composition, and Location of High-Poverty Neighborhoods." Rutgers Center for Urban Research and Education. New Brunswick, New Jersey.

Jepson Jr., E. and Edwards, M. 2010. "How Possible is Sustainable Urban Development? An Analysis of Perceptions about New Urbanism, Smart Growth and the Ecological City.” Planning Practice and Research, 4, pp. 417-437.

Jorge, D. 2012. "Public Transit Challenges in America: What can we Learn from Midsized Cities in Latin America?” University of the Bio Bio Press. Concepcion, Chile.

Kantor, P. 1995. The Dependent City Revisited: The Political Economy of Urban Development and Social Policy. Boulder, Colorado: Westview Press.

Katz, B. 2009. “The Origins of Hope VI.” In Cisneros, H. and Engdahl, L. (eds.), From Despair to Hope: Hope VI and the New Promise of Public Housing in America's Cities (pp. 15-30). Washington, D.C.: Brookings Institution Press.

Katz, M. 1996. In the Shadow of the Poorhouse. New York: Basic Books.

Kellbaugh, D. 2002. Repairing the American Metropolis: Commonplace Revisited. Seattle: University of Washington Press.

Kelly, J. 1992. "On Teaching the Process of the Practice of Prevention: Integrating the Concept of Prevention.” In Albee, G., Kessler, M., Goldston, S. and Joffe, J. (eds.), The Present and Future of Prevention. pp. 251-264. Beverly Hills: Sage Publications. 
Kenworthy, L. 2014. “America’s Social Democratic Future.” Foreign Affairs. Council on Foreign Relations. New York.

King, P. 1978. "Exclusionary Zoning and Open Housing: A Brief Judicial Review.” Journal of Housing Research, 68(4), pp. 459-469.

Klemens, C. 2007. “Model Cities”, in Goldfield, D. (ed.), Encyclopedia of American Urban History (pp. 484-486). Thousand Oaks, California: Sage Publications.

Kotkin, J. 2010. The Next Hundred Million: America in 2050. Penguin Press. London.

Koven, S. and Lyons, T. 2005. "Economic Development: What Local Governments Do.” International Management Association: Special Data Issue 2, pp. 1-12.

Kulash, W., Anglin, J., and Marks, D. 1990. “Traditional Neighborhood Development: Will the Traffic Work?” Development, 21, pp. 21-24.

Kurian, G. 1998. A Historical Guide to the U.S. Government, 1964-1984. Oxford, England: Oxford University Press.

Laffel, N. 2006. Promoting Public Transportation for Sustainable Development. Princeton University Institutional Repository. Princeton, New Jersey.

Leinberger, C. 2008. The Option of Urbanism. Island Press. Washington, D.C.

Levy, D. 2004. "Re-Envisioning Public Housing: Hope VI and the U.S. Federal Government's Role in Public Housing Provision.” In Thomas-Houston, M. and Schuller, M. (eds.), Homing Devices: The Poor as Targets of Public Housing Policy and Practice. Idaho Falls, Idaho: Lexington Books.

Lew, J. (2011, February 11). “The Easy Cuts are Behind Us.” New York Times. Retrieved from: www.nytimes.com.

Ley, D. 1996. The New Middle Class and the Remaking of the Central City. Oxford, England: Oxford University Press.

Leyden, K. 2003. "Social Capital and the Built Environment: The Importance of Walkable Neighborhoods”. American Journal of Public Health, 93(9), pp. 1546-1551.

Libby, P. 2012. The Lobbying Strategy Handbook. Sage Publications: Thousand Oaks, California.

Lin, J. 2011. The Power of Urban Ethnic Places: Cultural Heritage and Community Life. London: Routledge Press.

Louisville and Jefferson County Planning Commission. 2000. "Guideline 1: Community Form.” Cornerstone 2020. Louisville Metro Government. Louisville, Kentucky. 
Louisville GIS. 2015. “Neighborhood Poverty in Louisville.” Geographic Information Systems. Louisville, Kentucky.

Louisville Metro Chamber of Commerce. 2016. “Top 20 Private Sector Companies.” Greater Louisville Incorporated. Louisville, Kentucky.

Louisville Metro Government. 2015. “City News.” Louisville, Kentucky. Retrieved November 17, 2016, from: louisvilleky.gov.

Louisville Metro Government. 2015. “Louisville: A Focus on Poverty.” Greater Louisville Project. Louisville, Kentucky.

Louisville Metro Housing Authority. 2016. Louisville Metro Government. Louisville, Kentucky. Retrieved December 15, 2016, from: lmha1.org.

Louisville Metro Government. 2017. “Louisville Loop Trail.” Louisville, Kentucky. Retrieved November 19, 2016, from: louisvilleky.gov.

Lwin, K. and Muriyama, Y. 2011. "Modelling of Urban Green Space Walk-ability: EcoFriendly Walk-Score Calculator.” Computer, Environment and Urban Systems, 35(5), pp. 408-420.

Lustig, N. 2012. “Taxes, Transfers, and Income Redistribution in Latin America.” The World Bank, 1(2), pp. 1-8.

MacLeod, G. 2013. "New Urbanism/Smart Growth in the Scottish Highlands: Mobile Policies as Post Politics in Local Development Planning.” Urban Studies, 50(11), pp. 2196-2221.

Marcuse, P. 2000. “The New Urbanism: The Dangers so Far.” DISP- The Planning Review, 36(1), pp. 4-6.

Maurer, R. 2015. “Online Job Searching has Doubled since 2005.” Society for Human Resource Management. Alexandria, Virginia.

Martin, L. 2007. "Fighting for Control: Political Displacement in Atlanta's Gentrifying Neighborhoods.” Urban Affairs Review, 42(5), pp. 603-628.

McFarlane, A. 2000. "Race, Space and Place: The Internal Critique of the Empowerment Zone Program.” San Diego Law Review 36(295), pp. 1-38.

McKie, R. (2009, March 7). "Scientists to Issue Stark Warning over Dramatic New Sea Level Changes.” The Guardian. Retrieved from: www.theguardian.com. 
Minkler, M and Wallerstein, N. 2012. Community Organizing and Community Building for Health and Welfare. Third Edition. New Brunswick, New Jersey: Rutgers University Press.

Molotch, H. 1976. "The City as a Growth Machine.” American Journal of Sociology, 82(2), pp. 309-332.

Morgan, J. 2009. “The Role of Local Government in Economic Development.” University of North Carolina School of Government. Chapel Hill, North Carolina.

Nasar, J. 2003. “Does Neotraditional Development Build Community?” Journal of Planning Education and Research, 31(2), pp. 58-68.

National Park Service. 2010. National Register of Historic Places. United States Department of the Interior. Washington, D.C.

Neff, G. 2004. "The Failure of Finding Social Capital: An Evaluation of Microfinance Funding in the United States, 1996-1999.” In Sullivan, R. (ed.), CommunityBased Organizations: The Interaction of Social Capital and Local Context in Contemporary Urban Society. Detroit: Wayne State University Press.

Nelson, A. and Sanchez, T. 2005. "The Effectiveness of Urban Containment Regimes.” DISP: The Planning Review, 160(1), pp. 42-47.

Nelson, G. (2016, October 26). “The Deception of Density.” The Atlantic. Retrieved from www.theatlantic.com.

Nelson, L. (2016, August 11). “Trump: 'I am the Law and Order Candidate'.” Politico. Retrieved from: www.politico.com.

Norris, F. (2011, November 11.) “As Corporate Profits Rise, Workers Income Decreases.” New York Times. Retrieved from: www.nytimes.com.

North, D. 1955. "Location Theory and Regional Economic Growth.” Journal of the Political Economy, 63(3), pp. 243-251.

Norton Commons LLC. 2016. "Norton Commons: More Life per Square Foot.” Prospect, Kentucky. From: nortoncommons.com.

O’Connor, A. 2008. "Swimming against the Tide: A Brief History of Federal Policy in Poor Communities.” Brookings Institution. Washington, D. C.

Olmstead, F. 1896. “Report to United States Congress.” United States Congress. Washington, D.C. 
Orr, M. 2007. Transforming the City: Community Organizing and the Challenge of Political Change. Lawrence, Kansas: University of Kansas Press.

Osman, S. 2008. “The Decade of the Neighborhood.” In Schulman, E. and Zelizer, J. (eds.), Rightward Bound: Making America Conservative in the 1970s. Boston: Harvard University Press.

Pack, A. 2013. “Increasing Density: A Small-Town Approach to New Urbanism.” St. Louis Federal Reserve Bank. St. Louis.

Pendall, R. Theodos, B., and Hildner, K. 2014. "Why High-Poverty Neighborhoods Persist: The Role of Precarious Housing.” Urban Affairs Review, 22(1), pp. 3365.

Peterman, W. 2000. Neighborhood Planning and Community-Based Development. New York: Sage Publications.

Peterson, P. 1981. City Limits. Chicago: University of Chicago Press.

Pogodzinski, J. 2008. "The Effects of Exclusionary Zoning on Household Location: A Critical Review”. Journal of Housing Research, 2(2), pp. 145-160.

Poitcha, S. 2000. "Smart Growth and New Urbanism: What's the Difference?” New Urban News. Emmaus, Pennsylvania.

Popkin, S., Katz, B., Cunningham, M., Brown, K., Gustafson, J., and Turner, M. 2004. “A Decade of Hope VI.” Urban Institute. Washington, D.C.

Porter, M. 1997. "New Strategies for Inner-city Economic Development.” Economic Development Quarterly, 11(1), pp. 11-17.

Prater, S. 2011. The Affordability of New Urbanism in Atlanta. Georgia Institute of Technology Institutional Repository. Atlanta.

Pretsby, J. and Wandersman, A. 1985. "Capacity for Effectiveness: The Relationship between Coalition Structure and Community Impact.” Evaluation and Program Planning, 23(3), pp. 373-379.

Putnam, R. 2000. Bowling Alone. New York: Simon and Schuster.

Pyatok, M. 2000. Comment on Charles C. Bohl's "New Urbanism and the City: Potential Application and the Implications for Distressed Inner-City Neighborhoods" - the Politics of New Urban Design: New Urbanism vs. the Grassroots. Housing Policy Debate 11, pp. 803-804. 
Rahnama, M., Roshani, P., Hassani, A., and Seyed, H. 2012. "Use Principles of New Urbanism in Designing Sustainable Urban Places.” International Journal of Applied Science and Technology, 2(7), pp. 195-203.

Rosenbaum, J. 1995. "Changing Geography of Opportunity by Expanding Residential Choice.” Housing Policy Debate, 6(1), pp. 231-269.

Rosenblum, N. 2000. Membership and Morals: The Personal Uses of Pluralism in America. Princeton, New Jersey: Princeton University Press.

Rubin, H. 1988. "Shoot Anything that Flies, Claim Anything that Falls: Conversation with Econonomic Development Practitioners.” Economic Development Quarterly, 2(3), pp. 236-254.

Rusk, D. 1993. Cities without Suburbs. Washington, D.C.: Woodrow Wilson Center.

Ryan, D. 2016. "Fight over Affordable Housing in Norton Commons.” WFPL News. Retrieved December 10, 2016, from: wfpl.org. Louisville, Kentucky.

Sampson, R., Morenoff, J., and Gannon-Rowley, T. 2002. “Assessing Neighborhood Effects: Social Processes and New Directions in Research.” Annual Review of Sociology, 28, pp. 443-478.

Sands, G. and Reese, L. 2007. "Well-made Places: Resident Satisfaction in New Urban Communities.” Sustainable Development and Planning, 102, pp. 43-53.

Sassen, S. 2012. Cities in a World Economy (4 $4^{\text {th }}$ ed.). New York: Sage Publications.

Savitch, H. and Vogel, R. 2004. "Suburbs without a City: Power and City-County Consolidation.” Urban Affairs Review, 39(6), pp. 758-790.

Schnave, A. 1992. The Cost of HUD Multifamily Housing Programs. United States Department of Housing and Urban Development: Office of Policy Development and Research. Washington, D.C.

Schragge, E. 2013. Activism and Social Change: Lessons for Community Organizing. Toronto: University of Toronto Press.

Schragger, R. 2011. "Rethinking the Theory and Practice of Local Economic Development.” The University of Chicago Law Review, 77, pp. 311-340.

Schutt, R. 2001. “Activist Skills and Experience Questionnaire.” Vernal Education Project. Cleveland. 
Sclar, E. 2002. "Place Matters Somewhat, but Social Class Matters Even More.” Dissent, 49(2).

Self, R. 2003. American Babylon: Race and Struggle for Post-War Oakland. Princeton, New Jersey: Princeton University Press.

Sewan, L. 1999. "Bootstrap Capital: Microenterprise and the American Poor." Brookings Institution. Washington, D.C.

Shaeffer, H. and Gutierrez, I. 2013. "The Supplemental Nutrition Assistance Program and Material Hardships among Household with Children.” Social Service Review, 87(4), pp. 753-779.

Siranni, C. and Friedland. 2001. Civic Innovation in America: Community Empowerment, Public Policy, and the Movement for Civic Renewal. Berkeley, California: University of California Press.

Skobba, K. and Goetz, E. 2013. "Mobility Decisions of Very Low-Income Households." Cityscape, 15(2), pp. 158-172.

Smith, N. 2002. "New Globalism, New Urbanism, and Gentrification, as a Global Urban Strategy.” Antipode, 34(3), pp. 427-450.

Smith, N. 2007. "Toward a Theory of Gentrification: A Back to the City Movement by Capital, not the People.” Journal of the American Planning Association, 45(4), pp. 538-548.

Soifer, S. 2014. Community Economic Development in Social Work. New York: Columbia University Press.

Speer, P. and Hughes, J. 1995. "Community Organizing: An Ecological Route to Empowerment and Power.” American Journal of Community Psychology, 23(5), pp. 729-748.

Spence, L. 1993. "Rethinking the Social Role of Public Housing.” Housing Policy Debate, 4(3), pp. 355-368.

Staudt, K. and Stone, C. 2007. "Division and Fragmentation: The El Paso Experience in Global- Local Perspective.” In Orr, M. (ed.), Community Organizing and the Challenge of Political Change. Lawrence, Kansas: University of Kansas Press.

Sternberg, E. 2000. “An Integrative Theory of Urban Design.” Journal of American Planning Association, 66(3), pp. 265-278. 
Stueteville, R. 2014. “New Urbanism’s Impact on Midsized and Smaller Cities.” Better Cities and Towns. May Edition. Retrieved March 21, 2017, from: www.bettercities.net.

Steuteville, R. 2015. “The Four Stages of New Urbanism.” Better Cities and Towns. February Edition. Retrieved May 20, 2017, from: www.bettercities.net.

Stoecker, R. 1995. “Community, Movement, Organization: The Problem of Identity Convergence in Collective Action.” The Sociological Quarterly, 36(1), pp. 111130.

Stoecker, R. 1997. "The CDC Model of Urban Redevelopment: A Critique and an Alternative.” Journal of Urban Affairs, 19(1), pp. 1-22.

Stone, C. 1989. Regime Politics: Governing Atlanta, 1946-1988. Lawrence, Kansas: University of Kansas Press.

Talen, E. 1999. "Sense of Community and Neighborhood Form: An Assessment of the Social Doctrine of New Urbanism.” Urban Studies, 36(8), pp. 1361-1379.

Talen, E. 2008. "New Urbanism, Social Equity, and Post-Katrina Rebuilding in Mississippi.” Journal of Planning Education and Research, 27(3), pp. 277-293.

Talen, E. 2010. "Affordability in New Urbanist Development: Principle, Practice, and Strategy.” Journal of Urban Affairs, 32(4), pp. 489-510.

Talen, E. 2014. “Do-it-Yourself Urbanism: A History.” Journal of Planning History, 14(2), pp. 135-148.

Theimer, S. and Yost, P. 2009. "Did ACORN get too Big for its Own Good?” Associated Press. New York. Retrieved July 20, 2017, from nbcnews.com.

Tomer, A. 2012. "Where the Jobs Are: Employee Access to Jobs by Transit.” Brookings Institute. Washington, D.C.

Town Paper Publications. 2015. The Town Paper. Gaithersburg, Maryland. Retrieved from: thdtownpaper.com.

Transit Authority of the River City. 2016. "Routes and Schedules.” Louisville, Kentucky. Retrieved from: ridetarc.org.

Trudeau, D. 2013. “New Urbanism as Sustainable Development.” Geography Compass, 7, pp. 435-448. 
Trudeau, D. and Kaplan, J. 2015. "Is there the Diversity in the New Urbanism?: Analyzing the Demographic Characteristics of New Urbanist Neighborhoods in the United States.” Urban Geography, 36, pp. 1-25.

Turbov, M. and Piper, V. 2005. "Hope VI and Mixed-Finance Redevelopments: A Catalyst for Neighborhood Revival.” The Brookings Institution. Washington, D.C.

United States Bureau of Labor Statistics. 2015. Occupation Outlook Handbook. United States Department of Labor. Washington, D.C.

University of Louisville. 2016. “Clifton Neighborhood Plan Project.” Department of Urban and Public Affairs. Louisville, Kentucky.

United States Census Bureau. 1970. “Population and Housing.” United States Department of Commerce. Suitland, Maryland.

United States Census Bureau. 2000. “Population and Housing.” United States Department of Commerce. Suitland, Maryland.

United States Census Bureau. 2010. “Population and Housing.” United States Department of Commerce. Suitland, Maryland.

United States Census Bureau. 2010. “Commuting/Place of Work/Travel Time.” United States Department of Commerce. Suitland, Maryland.

United States Election Commission. 2014. "7 Tips to Strengthen Voter Education Programs.” Retrieved January 4, 2017, from: eac.gov. Washington, D.C.

Varady, D., Preiser, W., and Russel, F. 1998. New Directions in Public Housing. Rutgers Center for Urban Policy Research. New Brunswick, New Jersey.

Vartanian, T. 1999. "Adolescent Neighborhood Effects on Labor Market and Economic Outcomes.” Social Service Review, 73(2), pp. 142-167.

Von Hoffman, A. 2004. House by House, Block by Block. Oxford, England: Oxford University Press.

Wacquant, L. 2002. "From Slavery to Mass Incarceration: Rethinking the Race Question.” New Left Review, 13, pp. 41-60.

Walsh, J. 1997. "Stories of Renewal: Community-building and the Future of Urban America.” The Rockefeller Foundation. New York. 
Walka, A. 1972. Resident Participation in the Tucson Model Cities Program. University of Arizona Institutional Repository. Tucson, Arizona.

Walker, R. 2007. "The Affordability Paradox: New Urbanism is Great, but can it be Affordable?” Town Paper Publications. Gaithersburg, Maryland.

Warren, M. 2001. Democracy and Association. Princeton, New Jersey: Princeton University Press.

Weber, B. and Wallace, A. 2012. "Revealing the Empowerment Revolution: A Literature Review of the Model Cities Program.” Journal of Urban History 38(1), pp. 173-192.

Wekerle, G.R. 1985. "From Refuge to Service Center: Neighborhoods that Supports.” Sociological Focus, 18(2), pp. 79-95.

Wexler, H. 2001. "Hope VI: Market Means/Public Ends- The Goals, Strategies, and Midterm Lessons of HUD's Revitalization Demonstration Program.” Journal of Affordable Housing, 10(3), pp. 195-233.

Whyte, W. 1988. Rediscovering the Center. New York: Anchor Books.

Williams, D. 1997. The Road to Now: A History of Blacks in Montreal. Montreal: Vehicule Press.

Wilson, W. 1987. The Truly Disadvantaged. Chicago: University of Chicago Press.

Wilson, W. 1996. When Work Disappears. New York: Random House.

World Commission on Environment and Development. 1987. Our Common Future. Oxford England: Oxford University Press.

Yin, J. 2001. The Community Development System: Urban Politics and the Practice of Neighborhood Redevelopments in Two American Cities from the 1960s to the 1990s. Cornell University Institutional Repository. Ithaca, New York.

Zuckerman, M. (2014, July 13). “The Full-Time Scandal of Part-Time America.” Wall Street Journal. Retrieved from wsj.com. 


\begin{abstract}
APPENDIX A
PRIMARY DATA LOG: SPECIFIC AMENITIES OF CLIFTON, NORTON COMMONS, AND THE SURROUNDING AREAS OF EACH NEIGHBORHOOD
\end{abstract}

The following six tables list all of the amenities in Clifton, Norton Commons, and their surrounding areas, as well as the skill-level categorizations of potential employment facilities. This data was used for the presentation of the results in Chapters V-VII. The tables include Clifton; its nearby areas of Clifton Heights and Crescent Hill; Norton Commons; the suburban shopping area near Norton Commons; and the Wolf Trace subdivision near Norton Commons.

Table A.1- Clifton’s Specific Amenities.

\begin{tabular}{|l|l|l|l|l|}
\hline Street & $\begin{array}{l}\text { Number of Bus } \\
\text { Stops }\end{array}$ & $\begin{array}{l}\text { Side- } \\
\text { walk? }\end{array}$ & $\begin{array}{l}\text { Bike } \\
\text { Lane } \\
\text { Present? }\end{array}$ & $\begin{array}{l}\text { Automobile } \\
\text { Lane } \\
\text { Present? }\end{array}$ \\
\hline Jane & & Yes & No & No \\
\hline Keats & & Yes & No & No \\
\hline Street & & & & \\
\hline Payne & $\begin{array}{l}\text { Number of Bus } \\
\text { Stops }\end{array}$ & $\begin{array}{l}\text { Side- } \\
\text { walk? }\end{array}$ & $\begin{array}{l}\text { Bike } \\
\text { Lane } \\
\text { Present? }\end{array}$ & $\begin{array}{l}\text { Automobile } \\
\text { Lane } \\
\text { Present? }\end{array}$ \\
\hline & 7 & Yes & No & Yes \\
\hline
\end{tabular}




\begin{tabular}{|c|c|c|c|c|}
\hline $\begin{array}{l}\text { Establishment/ } \\
\text { Organization }\end{array}$ & $\begin{array}{l}\text { Type (Ahwahnee } \\
\text { Principle } \\
\text { Category) }\end{array}$ & Size & $\begin{array}{l}\text { Unskilled } \\
\text { Jobs } \\
\text { Available? }\end{array}$ & Industry \\
\hline $\begin{array}{l}\text { Bear Grass Missionary } \\
\text { Baptist Church }\end{array}$ & Misc. Civic & Small & No & Other \\
\hline $\begin{array}{l}\text { Clifton Universalist Unitarian } \\
\text { Church }\end{array}$ & Misc. Civic & Small & No & Other \\
\hline $\begin{array}{l}\text { St. Francis of Rome Catholic } \\
\text { Church }\end{array}$ & Misc. Civic & Small & No & Other \\
\hline Clifton Center & $\begin{array}{l}\text { Community } \\
\text { Center }\end{array}$ & Small & Yes & $\begin{array}{l}\text { Personal } \\
\text { Services }\end{array}$ \\
\hline Dharma Magela Yoga & $\begin{array}{l}\text { Misc. Business } \\
\text { Establishment }\end{array}$ & Small & No & $\begin{array}{l}\text { Personal } \\
\text { Services }\end{array}$ \\
\hline Sacred Heart Church & Misc. Civic & Small & No & Other \\
\hline $\begin{array}{l}\text { Louisville Paving and } \\
\text { Construction }\end{array}$ & $\begin{array}{l}\text { Misc. Business } \\
\text { Establishment }\end{array}$ & Small & No & Construction \\
\hline Street & $\begin{array}{l}\text { Number of Bus } \\
\text { Stops }\end{array}$ & $\begin{array}{l}\text { Side- } \\
\text { walk? }\end{array}$ & $\begin{array}{l}\text { Bike } \\
\text { Lane } \\
\text { Present? }\end{array}$ & $\begin{array}{l}\text { Automobile } \\
\text { Lane } \\
\text { Present? }\end{array}$ \\
\hline Ewing & 2 & Yes & No & No \\
\hline $\begin{array}{l}\text { Establishment/ } \\
\text { Organization }\end{array}$ & $\begin{array}{l}\text { Type (Ahwahnee } \\
\text { Principle } \\
\text { Category) }\end{array}$ & Size & $\begin{array}{l}\text { Unskilled } \\
\text { Jobs } \\
\text { Available? } \\
\end{array}$ & Industry \\
\hline League of Women Voters & Misc. Civic & N/A & N/A & Govt./Adm. \\
\hline $\begin{array}{l}\text { Create Diversity Studio and } \\
\text { Gallery }\end{array}$ & $\begin{array}{l}\text { Misc. Business } \\
\text { Establishment }\end{array}$ & Small & No & $\begin{array}{l}\text { Distributive } \\
\text { Services }\end{array}$ \\
\hline Street & $\begin{array}{l}\text { Number of Bus } \\
\text { Stops }\end{array}$ & $\begin{array}{l}\text { Side- } \\
\text { walk? }\end{array}$ & $\begin{array}{l}\text { Bike } \\
\text { Lane } \\
\text { Present? }\end{array}$ & $\begin{array}{l}\text { Automobile } \\
\text { Lane } \\
\text { Present? }\end{array}$ \\
\hline Rastetter & & Yes & No & No \\
\hline Street & $\begin{array}{l}\text { Number of Bus } \\
\text { Stops }\end{array}$ & $\begin{array}{l}\text { Side- } \\
\text { walk? }\end{array}$ & $\begin{array}{l}\text { Bike } \\
\text { Lane } \\
\text { Present? }\end{array}$ & $\begin{array}{l}\text { Automobile } \\
\text { Lane } \\
\text { Present? }\end{array}$ \\
\hline Clifton & & Yes & No & Yes \\
\hline $\begin{array}{l}\text { Establishment/ } \\
\text { Organization }\end{array}$ & $\begin{array}{l}\text { Type (Ahwahnee } \\
\text { Principle } \\
\text { Category) }\end{array}$ & Size & $\begin{array}{l}\text { Unskilled } \\
\text { Jobs } \\
\text { Available? }\end{array}$ & Industry \\
\hline $\begin{array}{l}\text { The Real Bryant-Burnett } \\
\text { Heating/Air Conditioning }\end{array}$ & $\begin{array}{l}\text { Misc. Business } \\
\text { Establishment }\end{array}$ & Small & No & Construction \\
\hline Street & $\begin{array}{l}\text { Number of Bus } \\
\text { Stops }\end{array}$ & $\begin{array}{l}\text { Side- } \\
\text { walk? }\end{array}$ & $\begin{array}{l}\text { Bike } \\
\text { Lane } \\
\text { Present? }\end{array}$ & $\begin{array}{l}\text { Automobile } \\
\text { Lane } \\
\text { Present? }\end{array}$ \\
\hline
\end{tabular}




\begin{tabular}{|c|c|c|c|c|}
\hline Frankfort & 2 & Yes & No & Yes \\
\hline $\begin{array}{l}\text { Establishment/ } \\
\text { Organization }\end{array}$ & $\begin{array}{l}\text { Type (Ahwahnee } \\
\text { Principle } \\
\text { Category) }\end{array}$ & Size & $\begin{array}{l}\text { Unskilled } \\
\text { Jobs } \\
\text { Available? }\end{array}$ & Industry \\
\hline Hair en Vogue Salon & $\begin{array}{l}\text { Misc. Business } \\
\text { Establishment }\end{array}$ & Small & No & $\begin{array}{l}\text { Personal } \\
\text { Services }\end{array}$ \\
\hline Walgreens & $\begin{array}{l}\text { Convenience } \\
\text { Store/Drug Store }\end{array}$ & Small & Yes & $\begin{array}{l}\text { Distributive } \\
\text { Services }\end{array}$ \\
\hline At the Italian Table & Restaurant & Small & Yes & $\begin{array}{l}\text { Personal } \\
\text { Services }\end{array}$ \\
\hline Matt Anthony's Record Shop & $\begin{array}{l}\text { Misc. Business } \\
\text { Establishment }\end{array}$ & Small & Yes & $\begin{array}{l}\text { Distributive } \\
\text { Services }\end{array}$ \\
\hline Panther Motors & $\begin{array}{l}\text { Misc. Business } \\
\text { Establishment }\end{array}$ & Small & No & $\begin{array}{l}\text { Distributive } \\
\text { Services }\end{array}$ \\
\hline Kamino’s Cantina & Restaurant & Small & Yes & $\begin{array}{l}\text { Personal } \\
\text { Services }\end{array}$ \\
\hline El Mundo & Restaurant & Small & Yes & $\begin{array}{l}\text { Personal } \\
\text { Services }\end{array}$ \\
\hline Bennie and Friends & $\begin{array}{l}\text { Misc. Business } \\
\text { Establishment }\end{array}$ & Small & Yes & $\begin{array}{l}\text { Personal } \\
\text { Services }\end{array}$ \\
\hline Please and Thank You & Restaurant & Small & Yes & $\begin{array}{l}\text { Personal } \\
\text { Services }\end{array}$ \\
\hline $\begin{array}{l}\text { Dan Burch Associates, } \\
\text { Incorporated (advertising and } \\
\text { communications) }\end{array}$ & $\begin{array}{l}\text { Misc. Business } \\
\text { Establishment }\end{array}$ & Small & No & $\begin{array}{l}\text { Business } \\
\text { Services }\end{array}$ \\
\hline Con Huevos & Restaurant & Small & Yes & $\begin{array}{l}\text { Personal } \\
\text { Services }\end{array}$ \\
\hline $\begin{array}{l}\text { Redefine Design (furniture } \\
\text { store) }\end{array}$ & $\begin{array}{l}\text { Misc. Business } \\
\text { Establishment }\end{array}$ & Small & Yes & $\begin{array}{l}\text { Distributive } \\
\text { Services }\end{array}$ \\
\hline Irish Rover & Bar & Small & Yes & $\begin{array}{l}\text { Personal } \\
\text { Services }\end{array}$ \\
\hline Vint & Restaurant & Small & Yes & $\begin{array}{l}\text { Personal } \\
\text { Services }\end{array}$ \\
\hline Volaire & Restaurant & Small & Yes & $\begin{array}{l}\text { Personal } \\
\text { Services }\end{array}$ \\
\hline $\begin{array}{l}\text { Crescent Hill Animal } \\
\text { Hospital }\end{array}$ & $\begin{array}{l}\text { Misc. Business } \\
\text { Establishment }\end{array}$ & Small & No & $\begin{array}{l}\text { Professional } \\
\text { Services }\end{array}$ \\
\hline Dave’s Import Auto Sales & $\begin{array}{l}\text { Misc. Business } \\
\text { Establishment }\end{array}$ & Small & No & $\begin{array}{l}\text { Distributive } \\
\text { Services }\end{array}$ \\
\hline Crave Café and Restaurant & Restaurant & Small & Yes & $\begin{array}{l}\text { Personal } \\
\text { Services }\end{array}$ \\
\hline Bourbon's Bistro & Restaurant & Small & Yes & $\begin{array}{l}\text { Personal } \\
\text { Services }\end{array}$ \\
\hline Four Sisters & Restaurant & Small & Yes & $\begin{array}{l}\text { Personal } \\
\text { Services }\end{array}$ \\
\hline
\end{tabular}




\begin{tabular}{|c|c|c|c|c|}
\hline Basa Moder Vietnamese & Restaurant & Small & Yes & $\begin{array}{l}\text { Personal } \\
\text { Services }\end{array}$ \\
\hline Zen Garden & Restaurant & Small & Yes & $\begin{array}{l}\text { Personal } \\
\text { Services }\end{array}$ \\
\hline Asian Wok & Restaurant & Small & Yes & $\begin{array}{l}\text { Personal } \\
\text { Services }\end{array}$ \\
\hline 50 Lou (gift shop) & $\begin{array}{l}\text { Misc. Business } \\
\text { Establishment }\end{array}$ & Small & Yes & $\begin{array}{l}\text { Distributive } \\
\text { Services }\end{array}$ \\
\hline The Hub Louisville & Bar & Small & Yes & $\begin{array}{l}\text { Personal } \\
\text { Services }\end{array}$ \\
\hline $\begin{array}{l}\text { European Splendor } \\
\text { (furniture) }\end{array}$ & $\begin{array}{l}\text { Misc. Business } \\
\text { Establishment }\end{array}$ & Small & Yes & $\begin{array}{l}\text { Distributive } \\
\text { Services }\end{array}$ \\
\hline Clifton Pizza Company & Restaurant & Small & Yes & $\begin{array}{l}\text { Personal } \\
\text { Services }\end{array}$ \\
\hline Lexie’s Trading Port & $\begin{array}{l}\text { Misc. Business } \\
\text { Establishment }\end{array}$ & Small & Yes & $\begin{array}{l}\text { Distributive } \\
\text { Services }\end{array}$ \\
\hline $\begin{array}{l}\text { Blackburn and Davis Air } \\
\text { Conditioning }\end{array}$ & $\begin{array}{l}\text { Misc. Business } \\
\text { Establishment }\end{array}$ & Small & No & Construction \\
\hline Comfy Cow & Restaurant & Small & Yes & $\begin{array}{l}\text { Personal } \\
\text { Services }\end{array}$ \\
\hline Friends Jewelry & $\begin{array}{l}\text { Misc. Business } \\
\text { Establishment }\end{array}$ & Small & Yes & $\begin{array}{l}\text { Distributive } \\
\text { Services }\end{array}$ \\
\hline Doodle’s Antiques & $\begin{array}{l}\text { Misc. Business } \\
\text { Establishment }\end{array}$ & Small & Yes & $\begin{array}{l}\text { Distributive } \\
\text { Services }\end{array}$ \\
\hline Casablanca & Restaurant & Small & Yes & $\begin{array}{l}\text { Personal } \\
\text { Services }\end{array}$ \\
\hline Five Star Tattoo & $\begin{array}{l}\text { Misc. Business } \\
\text { Establishment }\end{array}$ & Small & No & $\begin{array}{l}\text { Personal } \\
\text { Services }\end{array}$ \\
\hline Time 4 Thai & Restaurant & Small & Yes & $\begin{array}{l}\text { Personal } \\
\text { Services }\end{array}$ \\
\hline The Grape Leaf & Restaurant & Small & Yes & $\begin{array}{l}\text { Personal } \\
\text { Services }\end{array}$ \\
\hline $\begin{array}{l}\text { Kentucky School for the } \\
\text { Blind }\end{array}$ & School & Small & No & $\begin{array}{l}\text { Educational } \\
\text { Services }\end{array}$ \\
\hline Third Lutheran Church & Misc. Civic & Small & No & Other \\
\hline The Reynolds Grocery & Grocery Store & Small & Yes & $\begin{array}{l}\text { Distributive } \\
\text { Services }\end{array}$ \\
\hline Guest Room Records & $\begin{array}{l}\text { Misc. Business } \\
\text { Establishment }\end{array}$ & Small & Yes & $\begin{array}{l}\text { Distributive } \\
\text { Services }\end{array}$ \\
\hline Props Barber Shop & $\begin{array}{l}\text { Misc. Business } \\
\text { Establishment }\end{array}$ & Small & No & $\begin{array}{l}\text { Personal } \\
\text { Services }\end{array}$ \\
\hline $\begin{array}{l}\text { Sweet Surrender Dessert Cafe } \\
\end{array}$ & Restaurant & Small & Yes & $\begin{array}{l}\text { Personal } \\
\text { Services }\end{array}$ \\
\hline Hilltop Tavern & Bar & Small & Yes & $\begin{array}{l}\text { Personal } \\
\text { Services }\end{array}$ \\
\hline
\end{tabular}




\begin{tabular}{|c|c|c|c|c|}
\hline $\begin{array}{l}\text { Kavier Forge Architectural } \\
\text { Gallery }\end{array}$ & $\begin{array}{l}\text { Misc. Business } \\
\text { Establishment }\end{array}$ & Small & Yes & $\begin{array}{l}\text { Distributive } \\
\text { Services }\end{array}$ \\
\hline North End Cafe & Restaurant & Small & Yes & $\begin{array}{l}\text { Personal } \\
\text { Services }\end{array}$ \\
\hline $\begin{array}{l}\text { SPA Tax and Wealth } \\
\text { Services }\end{array}$ & $\begin{array}{l}\text { Misc. Business } \\
\text { Establishment }\end{array}$ & Small & No & $\begin{array}{l}\text { Business } \\
\text { Services }\end{array}$ \\
\hline Silver Dollar & Bar & Small & Yes & $\begin{array}{l}\text { Personal } \\
\text { Services }\end{array}$ \\
\hline $\begin{array}{l}\text { Barro de 1758- Member of } \\
\text { Osaka }\end{array}$ & Restaurant & Small & Yes & $\begin{array}{l}\text { Personal } \\
\text { Services }\end{array}$ \\
\hline Clifton Food Mart & $\begin{array}{l}\text { Convenience } \\
\text { Store }\end{array}$ & Small & Yes & $\begin{array}{l}\text { Distributive } \\
\text { Services }\end{array}$ \\
\hline Frankfort Avenue Church & Misc. Civic & Small & No & Other \\
\hline Clifton Baptist Church & Misc. Civic & Small & No & Other \\
\hline $\begin{array}{l}\text { The Finishing Touch Cross- } \\
\text { Stitch Shop }\end{array}$ & $\begin{array}{l}\text { Misc. Business } \\
\text { Establishment }\end{array}$ & Small & Yes & $\begin{array}{l}\text { Distributive } \\
\text { Services }\end{array}$ \\
\hline $\begin{array}{l}\text { Avatar Holistic Veterinary } \\
\text { Services }\end{array}$ & $\begin{array}{l}\text { Misc. Business } \\
\text { Establishment }\end{array}$ & Small & No & $\begin{array}{l}\text { Professional } \\
\text { Services }\end{array}$ \\
\hline Core Fluency Pilates & $\begin{array}{l}\text { Misc. Business } \\
\text { Establishment }\end{array}$ & Small & No & $\begin{array}{l}\text { Personal } \\
\text { Services }\end{array}$ \\
\hline Scissors/Rock/Paper Salon & $\begin{array}{l}\text { Misc. Business } \\
\text { Establishment }\end{array}$ & Small & No & $\begin{array}{l}\text { Personal } \\
\text { Services }\end{array}$ \\
\hline Sister Dragonfly Gallery & $\begin{array}{l}\text { Misc. Business } \\
\text { Establishment }\end{array}$ & Small & No & $\begin{array}{l}\text { Distributive } \\
\text { Services }\end{array}$ \\
\hline Nussbaum Antiques & $\begin{array}{l}\text { Misc. Business } \\
\text { Establishment }\end{array}$ & Small & Yes & $\begin{array}{l}\text { Distributive } \\
\text { Services }\end{array}$ \\
\hline $\begin{array}{l}\text { Maid in Louisville } \\
\text { Professional Cleaning } \\
\text { Services }\end{array}$ & $\begin{array}{l}\text { Misc. Business } \\
\text { Establishment }\end{array}$ & Small & Yes & $\begin{array}{l}\text { Personal } \\
\text { Services }\end{array}$ \\
\hline A Reader’s Corner Bookstore & $\begin{array}{l}\text { Misc. Business } \\
\text { Establishment }\end{array}$ & Small & Yes & $\begin{array}{l}\text { Distributive } \\
\text { Services }\end{array}$ \\
\hline Osaka Sushi Bar & Restaurant & Small & Yes & $\begin{array}{l}\text { Personal } \\
\text { Services }\end{array}$ \\
\hline Elizabeth’s Timeless Attire & Clothing Store & Small & Yes & $\begin{array}{l}\text { Distributive } \\
\text { Services }\end{array}$ \\
\hline Varanese & Restaurant & Small & Yes & $\begin{array}{l}\text { Personal } \\
\text { Services }\end{array}$ \\
\hline Nancy’s Bagel Grounds & Restaurant & Small & Yes & $\begin{array}{l}\text { Personal } \\
\text { Services }\end{array}$ \\
\hline J. Gumbo’s & Restaurant & Small & Yes & $\begin{array}{l}\text { Personal } \\
\text { Services }\end{array}$ \\
\hline Doggy Boot Camp & $\begin{array}{l}\text { Misc. Business } \\
\text { Establishment }\end{array}$ & Small & Yes & $\begin{array}{l}\text { Personal } \\
\text { Services }\end{array}$ \\
\hline $\begin{array}{l}\text { Electric Blueprint Supply } \\
\text { Company }\end{array}$ & $\begin{array}{l}\text { Misc. Business } \\
\text { Establishment }\end{array}$ & Small & No & $\begin{array}{l}\text { Distributive } \\
\text { Services }\end{array}$ \\
\hline
\end{tabular}




\begin{tabular}{|c|c|c|c|c|}
\hline $\begin{array}{l}\text { Chris Papp Frames/Yvonne } \\
\text { Rapp Gallery }\end{array}$ & $\begin{array}{l}\text { Misc. Business } \\
\text { Establishment }\end{array}$ & Small & No & $\begin{array}{l}\text { Distributive } \\
\text { Services }\end{array}$ \\
\hline $\begin{array}{l}\text { Cunningham Doors and } \\
\text { Windows }\end{array}$ & $\begin{array}{l}\text { Misc. Business } \\
\text { Establishment }\end{array}$ & Small & No & Construction \\
\hline Phil’s Pawn Shop & $\begin{array}{l}\text { Misc. Business } \\
\text { Establishment }\end{array}$ & Small & Yes & $\begin{array}{l}\text { Distributive } \\
\text { Services }\end{array}$ \\
\hline Street & $\begin{array}{l}\text { Number of Bus } \\
\text { Stops }\end{array}$ & $\begin{array}{l}\text { Side- } \\
\text { walk? }\end{array}$ & $\begin{array}{l}\text { Bike } \\
\text { Lane } \\
\text { Present? }\end{array}$ & $\begin{array}{l}\text { Automobile } \\
\text { Lane } \\
\text { Present? }\end{array}$ \\
\hline New Main & & Yes & No & No \\
\hline $\begin{array}{l}\text { Establishment/ } \\
\text { Organization }\end{array}$ & $\begin{array}{l}\text { Type (Ahwahnee } \\
\text { Principle } \\
\text { Category) }\end{array}$ & Size & $\begin{array}{l}\text { Unskilled } \\
\text { Jobs } \\
\text { Available? }\end{array}$ & Industry \\
\hline $\begin{array}{l}\text { Bradford Newhall } \\
\text { Construction Company }\end{array}$ & $\begin{array}{l}\text { Misc. Business } \\
\text { Establishment }\end{array}$ & Small & No & Construction \\
\hline Street & $\begin{array}{l}\text { Number of Bus } \\
\text { Stops? }\end{array}$ & $\begin{array}{l}\text { Side- } \\
\text { walk? }\end{array}$ & $\begin{array}{l}\text { Bike } \\
\text { Lane } \\
\text { Present? }\end{array}$ & $\begin{array}{l}\text { Automobile } \\
\text { Lane } \\
\text { Present? }\end{array}$ \\
\hline Waverly & & Yes & No & No \\
\hline Weist & & Yes & No & No \\
\hline Street & $\begin{array}{l}\text { Number of Bus } \\
\text { Stops? }\end{array}$ & $\begin{array}{l}\text { Side- } \\
\text { walk? }\end{array}$ & $\begin{array}{l}\text { Bike } \\
\text { Lane } \\
\text { Present? }\end{array}$ & $\begin{array}{l}\text { Automobile } \\
\text { Lane } \\
\text { Present? }\end{array}$ \\
\hline Brownsboro & 1 & Yes & No & Yes \\
\hline $\begin{array}{l}\text { Establishment/ } \\
\text { Organization }\end{array}$ & Type & Size & $\begin{array}{l}\text { Unskilled } \\
\text { Jobs } \\
\text { Available? }\end{array}$ & Industry \\
\hline Kroger Gas Station & $\begin{array}{l}\text { Convenience } \\
\text { Store/Drug Store }\end{array}$ & Small & Yes & $\begin{array}{l}\text { Distributive } \\
\text { Services }\end{array}$ \\
\hline McDonald's & Restaurant & Small & Yes & $\begin{array}{l}\text { Personal } \\
\text { Services }\end{array}$ \\
\hline Speedway & $\begin{array}{l}\text { Convenience } \\
\text { Store/Drug Store }\end{array}$ & Small & Yes & $\begin{array}{l}\text { Distributive } \\
\text { Services }\end{array}$ \\
\hline Kroger & Grocery Store & Small & Yes & $\begin{array}{l}\text { Distributive } \\
\text { Services }\end{array}$ \\
\hline CVS & $\begin{array}{l}\text { Convenience/Drug } \\
\text { Store }\end{array}$ & Small & Yes & $\begin{array}{l}\text { Distributive } \\
\text { Services }\end{array}$ \\
\hline Phenomenal Salon & $\begin{array}{l}\text { Misc. Business } \\
\text { Establishment }\end{array}$ & Small & No & $\begin{array}{l}\text { Personal } \\
\text { Services }\end{array}$ \\
\hline Café Aroma Mexican Food & Restaurant & Small & Yes & $\begin{array}{l}\text { Personal } \\
\text { Services }\end{array}$ \\
\hline Family Dentistry & $\begin{array}{l}\text { Misc. Business } \\
\text { Establishment }\end{array}$ & Small & No & $\begin{array}{l}\text { Professional } \\
\text { Services }\end{array}$ \\
\hline
\end{tabular}




\begin{tabular}{|c|c|c|c|c|}
\hline Liberty Tax & $\begin{array}{l}\text { Misc. Business } \\
\text { Establishment }\end{array}$ & Small & No & $\begin{array}{l}\text { Business } \\
\text { Services }\end{array}$ \\
\hline Louisville Sports Cards & $\begin{array}{l}\text { Misc. Business } \\
\text { Establishment }\end{array}$ & Small & Yes & $\begin{array}{l}\text { Distributive } \\
\text { Services }\end{array}$ \\
\hline $\begin{array}{l}\text { Kentuckiana Children’s } \\
\text { Center: The Center for } \\
\text { Chiropractic Healthcare }\end{array}$ & $\begin{array}{l}\text { Misc. Business } \\
\text { Establishment }\end{array}$ & Small & No & $\begin{array}{l}\text { Professional } \\
\text { Services }\end{array}$ \\
\hline Street & $\begin{array}{l}\text { Number of Bus } \\
\text { Stops }\end{array}$ & $\begin{array}{l}\text { Side- } \\
\text { walk? }\end{array}$ & $\begin{array}{l}\text { Bike } \\
\text { Lane } \\
\text { Present? }\end{array}$ & $\begin{array}{l}\text { Automobile } \\
\text { Lane } \\
\text { Present? }\end{array}$ \\
\hline Vernon & & Yes & No & No \\
\hline Sycamore & & Yes & No & No \\
\hline Pope & & Yes & No & No \\
\hline Charlton & & Yes & No & No \\
\hline Arlington & & Yes & No & No \\
\hline Stevenson & & Yes & No & No \\
\hline William & & Yes & No & No \\
\hline Street & $\begin{array}{l}\text { Number of Bus } \\
\text { Stops }\end{array}$ & $\begin{array}{l}\text { Side- } \\
\text { walk? }\end{array}$ & $\begin{array}{l}\text { Bike } \\
\text { Lane } \\
\text { Present? }\end{array}$ & $\begin{array}{l}\text { Automobile } \\
\text { Lane } \\
\text { Present? }\end{array}$ \\
\hline Melwood & 1 & Yes & No & Yes \\
\hline Establishment/Organization & $\begin{array}{l}\text { Type (Ahwahnee } \\
\text { Principle } \\
\text { Category) }\end{array}$ & Size & $\begin{array}{l}\text { Unskilled } \\
\text { Jobs } \\
\text { Available? }\end{array}$ & Industry \\
\hline Bob Collet Auto Wreckers & $\begin{array}{l}\text { Misc. Business } \\
\text { Establishment }\end{array}$ & Small & No & $\begin{array}{l}\text { Distributive } \\
\text { Services }\end{array}$ \\
\hline Allison's Garden and Gifts & $\begin{array}{l}\text { Misc. Business } \\
\text { Establishment } \\
\end{array}$ & Small & Yes & $\begin{array}{l}\text { Distributive } \\
\text { Services }\end{array}$ \\
\hline $\begin{array}{l}\text { Excel Shop (furniture } \\
\text { restoration) }\end{array}$ & $\begin{array}{l}\text { Misc. Business } \\
\text { Establishment }\end{array}$ & Small & No & $\begin{array}{l}\text { Personal } \\
\text { Services }\end{array}$ \\
\hline Street & $\begin{array}{l}\text { Number of Bus } \\
\text { Stops }\end{array}$ & $\begin{array}{l}\text { Side- } \\
\text { walk? }\end{array}$ & $\begin{array}{l}\text { Bike } \\
\text { Lane } \\
\text { Present? }\end{array}$ & $\begin{array}{l}\text { Automobile } \\
\text { Lane } \\
\text { Present? }\end{array}$ \\
\hline Halderman & & No & No & No \\
\hline Coral & & Yes & No & No \\
\hline Emerald & & No & No & No \\
\hline
\end{tabular}




\begin{tabular}{|l|l|l|l|l|}
\hline Onyx & & Yes & No & No \\
\hline & & & & \\
& & & & \\
\hline Saunders & & Yes & No & No \\
\hline Albany & & No & No & No \\
\hline Sturgis & & No & No & No \\
\hline Stoll & & No & No & No \\
\hline State & Yes & No & No \\
\hline William & Yes & No & No \\
\hline
\end{tabular}

Table A.2- Clifton Heights' Specific Amenities.

\begin{tabular}{|l|l|l|l|l|}
\hline Street & $\begin{array}{l}\text { Number of Bus } \\
\text { Stops }\end{array}$ & $\begin{array}{l}\text { Sidewalk } \\
\text { Present? }\end{array}$ & $\begin{array}{l}\text { Bike Lane } \\
\text { Present? }\end{array}$ & $\begin{array}{l}\text { Automobile } \\
\text { Lane } \\
\text { Present? }\end{array}$ \\
\hline Brownsboro & Yes & No & Yes \\
\hline $\begin{array}{l}\text { Establishment/ } \\
\text { Organization }\end{array}$ & $\begin{array}{l}\text { Type (Ahwahnee } \\
\text { Principle } \\
\text { Category) }\end{array}$ & $\begin{array}{l}\text { Size } \\
\text { Misc. Business } \\
\text { Establishment }\end{array}$ & $\begin{array}{l}\text { Unskilled } \\
\text { Jobs } \\
\text { Available? }\end{array}$ & Industry \\
\hline Family Dollar & $\begin{array}{l}\text { Misc. Business } \\
\text { Establishment }\end{array}$ & Small & Yes & $\begin{array}{l}\text { Yistributive } \\
\text { Services }\end{array}$ \\
\hline $\begin{array}{l}\text { The Laundry Basket } \\
\text { (laundromat) }\end{array}$ & Restaurant & Small & Yes & $\begin{array}{l}\text { Personal } \\
\text { Services }\end{array}$ \\
\hline Papa John's & $\begin{array}{l}\text { Mersonal } \\
\text { Services }\end{array}$ \\
\hline $\begin{array}{l}\text { LB's Business Electric Beach } \\
\text { Tanning Center }\end{array}$ & $\begin{array}{l}\text { Misc. Business } \\
\text { Establishment }\end{array}$ & Small & Yes & $\begin{array}{l}\text { Personal } \\
\text { Services }\end{array}$ \\
\hline $\begin{array}{l}\text { Brownsboro Road } \\
\text { Quality Childcare }\end{array}$ & $\begin{array}{l}\text { Misc. Business } \\
\text { Establishment }\end{array}$ & Small & Yes & $\begin{array}{l}\text { Social } \\
\text { Services }\end{array}$ \\
\hline H \& R Block & Clothing Store & Small & Yes & $\begin{array}{l}\text { Business } \\
\text { Services }\end{array}$ \\
\hline BJ's Consignment & Restaurant & Small & Yes & $\begin{array}{l}\text { Persibutive } \\
\text { Services }\end{array}$ \\
\hline Little Caesar's & $\begin{array}{l}\text { Misc. Business } \\
\text { Establishment }\end{array}$ & Small & No & $\begin{array}{l}\text { Personal } \\
\text { Services }\end{array}$ \\
\hline New York Nails & $\begin{array}{l}\text { Sersonal } \\
\text { Services }\end{array}$ \\
\hline Subway & Small & Yes & \\
\hline
\end{tabular}




\begin{tabular}{|c|c|c|c|c|}
\hline $\begin{array}{l}\text { Great Wall Chinese } \\
\text { Restaurant }\end{array}$ & Restaurant & Small & Yes & $\begin{array}{l}\text { Personal } \\
\text { Services }\end{array}$ \\
\hline StorAll Storage & $\begin{array}{l}\text { Misc. Business } \\
\text { Establishment }\end{array}$ & Small & Yes & $\begin{array}{l}\text { Personal } \\
\text { Services }\end{array}$ \\
\hline $\begin{array}{l}\text { Brownsboro Auto } \\
\text { Detail }\end{array}$ & $\begin{array}{l}\text { Misc. Business } \\
\text { Establishment }\end{array}$ & Small & Yes & $\begin{array}{l}\text { Personal } \\
\text { Services }\end{array}$ \\
\hline $\begin{array}{l}\text { Kremer’s Smoke } \\
\text { Shop }\end{array}$ & $\begin{array}{l}\text { Misc. Business } \\
\text { Establishment }\end{array}$ & Small & Yes & $\begin{array}{l}\text { Distributive } \\
\text { Services }\end{array}$ \\
\hline $\begin{array}{l}\text { Thomas R Clark PSC } \\
\text { CPA }\end{array}$ & $\begin{array}{l}\text { Misc. Business } \\
\text { Establishment }\end{array}$ & Small & No & $\begin{array}{l}\text { Business } \\
\text { Services }\end{array}$ \\
\hline $\begin{array}{l}\text { Macc and Company } \\
\text { Hair Salon }\end{array}$ & $\begin{array}{l}\text { Misc. Business } \\
\text { Establishment }\end{array}$ & Small & No & $\begin{array}{l}\text { Personal } \\
\text { Services }\end{array}$ \\
\hline Lampshade, Etc. & $\begin{array}{l}\text { Misc. Business } \\
\text { Establishment }\end{array}$ & Small & Yes & $\begin{array}{l}\text { Distributive } \\
\text { Services }\end{array}$ \\
\hline Urban Betty Salon & $\begin{array}{l}\text { Misc. Business } \\
\text { Establishment }\end{array}$ & Small & No & $\begin{array}{l}\text { Personal } \\
\text { Services }\end{array}$ \\
\hline $\begin{array}{l}\text { Pay Less Phone } \\
\text { Repair }\end{array}$ & $\begin{array}{l}\text { Misc. Business } \\
\text { Establishment }\end{array}$ & Small & No & $\begin{array}{l}\text { Personal } \\
\text { Services }\end{array}$ \\
\hline $\begin{array}{l}\text { Whiskey By the } \\
\text { Drink Tavern }\end{array}$ & Bar & Small & Yes & $\begin{array}{l}\text { Personal } \\
\text { Services }\end{array}$ \\
\hline $\begin{array}{l}\text { Davis Electronics: } \\
\text { Two Way Radios }\end{array}$ & $\begin{array}{l}\text { Misc. Business } \\
\text { Establishment }\end{array}$ & Small & No & $\begin{array}{l}\text { Distributive } \\
\text { Services }\end{array}$ \\
\hline $\begin{array}{l}\text { Advance America } \\
\text { Cash Advance }\end{array}$ & $\begin{array}{l}\text { Misc. Business } \\
\text { Establishment }\end{array}$ & Small & Yes & $\begin{array}{l}\text { Personal } \\
\text { Services }\end{array}$ \\
\hline Dixie Dry Cleaners & $\begin{array}{l}\text { Misc. Business } \\
\text { Establishment }\end{array}$ & Small & Yes & $\begin{array}{l}\text { Personal } \\
\text { Services }\end{array}$ \\
\hline Rally's & Restaurant & Small & Yes & $\begin{array}{l}\text { Personal } \\
\text { Services }\end{array}$ \\
\hline Thornton's & $\begin{array}{l}\text { Convenience/Drug } \\
\text { Store }\end{array}$ & Small & Yes & $\begin{array}{l}\text { Distributive } \\
\text { Services }\end{array}$ \\
\hline $\begin{array}{l}\text { Louisville’s O2: } \\
\text { "Helping you } \\
\text { Breathe Easier" }\end{array}$ & $\begin{array}{l}\text { Professional } \\
\text { Services }\end{array}$ & Small & No & $\begin{array}{l}\text { Professional } \\
\text { Services }\end{array}$ \\
\hline $\begin{array}{l}\text { Classical } \\
\text { Acupuncture and } \\
\text { Herbs }\end{array}$ & $\begin{array}{l}\text { Misc. Business } \\
\text { Establishment }\end{array}$ & Small & No & $\begin{array}{l}\text { Personal } \\
\text { Services }\end{array}$ \\
\hline $\begin{array}{l}\text { La Bella Donna } \\
\text { Salon }\end{array}$ & $\begin{array}{l}\text { Misc. Business } \\
\text { Establishment }\end{array}$ & Small & No & $\begin{array}{l}\text { Personal } \\
\text { Services }\end{array}$ \\
\hline $\begin{array}{l}\text { Check Into Cash } \\
\text { Payday Advance } \\
\text { Center }\end{array}$ & $\begin{array}{l}\text { Misc. Business } \\
\text { Establishment }\end{array}$ & Small & Yes & $\begin{array}{l}\text { Personal } \\
\text { Services }\end{array}$ \\
\hline Metro PCS & $\begin{array}{l}\text { Misc. Business } \\
\text { Establishment }\end{array}$ & Small & Yes & $\begin{array}{l}\text { Distributive } \\
\text { Services }\end{array}$ \\
\hline $\begin{array}{l}\text { Sam's Hot Dog } \\
\text { Stand }\end{array}$ & Restaurant & Small & Yes & $\begin{array}{l}\text { Personal } \\
\text { Services }\end{array}$ \\
\hline
\end{tabular}




\begin{tabular}{|l|l|l|l|l|}
\hline Picture Perfect Salon & $\begin{array}{l}\text { Misc. Business } \\
\text { Establishment }\end{array}$ & Small & Yes & $\begin{array}{l}\text { Personal } \\
\text { Services }\end{array}$ \\
\hline Street & $\begin{array}{l}\text { Number of Bus } \\
\text { Stops }\end{array}$ & $\begin{array}{l}\text { Sidewalk } \\
\text { Present? }\end{array}$ & $\begin{array}{l}\text { Bike Lane } \\
\text { Present? }\end{array}$ & $\begin{array}{l}\text { Automobile } \\
\text { Lane } \\
\text { Present? }\end{array}$ \\
\hline Kenilworth & & Yes & No & No \\
\hline Lindsay & 2 & Yes & No & No \\
\hline Mount Holly & & Yes & No & No \\
\hline Cleveland & & Yes & No & No \\
\hline Melwood & & Yes & No & Yes \\
\hline Prescher Ridge & & Yes & No & No \\
\hline Delmont & & Yes & No & No \\
\hline Thompson & & No & No & No \\
\hline
\end{tabular}

Table A.3-Crescent Hill’s Specific Amenities.

\begin{tabular}{|l|l|l|l|l|}
\hline Street & $\begin{array}{l}\text { Number of } \\
\text { Bus Stops }\end{array}$ & $\begin{array}{l}\text { Sidewalk } \\
\text { Present? }\end{array}$ & $\begin{array}{l}\text { Bike Lane } \\
\text { Present? }\end{array}$ & $\begin{array}{l}\text { Automobile } \\
\text { Lane } \\
\text { Present? }\end{array}$ \\
\hline Frankfort & 3 & Yes & No & Yes \\
\hline $\begin{array}{l}\text { Establishment/ } \\
\text { Organization }\end{array}$ & $\begin{array}{l}\text { Type } \\
\text { (Ahwahnee } \\
\text { Principle } \\
\text { Category) }\end{array}$ & Size & $\begin{array}{l}\text { Unskilled } \\
\text { Jobs } \\
\text { Available? }\end{array}$ & Industry \\
\hline Art and Soul Jewelry & $\begin{array}{l}\text { Misc. Business } \\
\text { Establishment }\end{array}$ & Small & Yes & $\begin{array}{l}\text { Distributive } \\
\text { Services }\end{array}$ \\
\hline Craft House & Restaurant & Small & Yes & $\begin{array}{l}\text { Personal } \\
\text { Services }\end{array}$ \\
\hline The Wino Rack (wine store) & $\begin{array}{l}\text { Misc. Business } \\
\text { Establishment }\end{array}$ & Small & Yes & $\begin{array}{l}\text { Distributive } \\
\text { Services }\end{array}$ \\
\hline Oscar's Hardware & $\begin{array}{l}\text { Misc. Business } \\
\text { Establishment }\end{array}$ & Small & Yes & $\begin{array}{l}\text { Distributive } \\
\text { Services }\end{array}$ \\
\hline $\begin{array}{l}\text { Crescent Hill Fire } \\
\text { Department }\end{array}$ & Misc. Civic & Small & No & $\begin{array}{l}\text { Social } \\
\text { Services }\end{array}$ \\
\hline US Nails and Spa & $\begin{array}{l}\text { Misc. Business } \\
\text { Establishment }\end{array}$ & Small & Yes & $\begin{array}{l}\text { Personal } \\
\text { Services }\end{array}$ \\
\hline Crescent Hill Childcare & $\begin{array}{l}\text { Misc. Business } \\
\text { Establishment }\end{array}$ & Small & Yes & $\begin{array}{l}\text { Social } \\
\text { Services }\end{array}$ \\
\hline $\begin{array}{l}\text { Side-by-Side Family Arts } \\
\text { and Crafts Studio }\end{array}$ & $\begin{array}{l}\text { Misc. Business } \\
\text { Establishment }\end{array}$ & Small & No & $\begin{array}{l}\text { Distributive } \\
\text { Services }\end{array}$ \\
\hline
\end{tabular}




\begin{tabular}{|c|c|c|c|c|}
\hline $\begin{array}{l}\text { Fond Louisville’s } \\
\text { Homemade Grocery }\end{array}$ & Grocery Store & Small & Yes & $\begin{array}{l}\text { Distributive } \\
\text { Services }\end{array}$ \\
\hline Center for Healing Arts & $\begin{array}{l}\text { Misc. Business } \\
\text { Establishment }\end{array}$ & Small & No & $\begin{array}{l}\text { Personal } \\
\text { Services }\end{array}$ \\
\hline $\begin{array}{l}\text { Crescent Hill United } \\
\text { Methodist Church }\end{array}$ & Misc. Civic & Small & No & Other \\
\hline $\begin{array}{l}\text { Arch L. Heady and Son } \\
\text { Funeral Home and Services }\end{array}$ & Misc. Civic & Small & No & $\begin{array}{l}\text { Personal } \\
\text { Services }\end{array}$ \\
\hline $\begin{array}{l}\text { Evolve- The Men’s Resale } \\
\text { Store }\end{array}$ & $\begin{array}{l}\text { Clothing } \\
\text { Store }\end{array}$ & Small & Yes & $\begin{array}{l}\text { Distributive } \\
\text { Services }\end{array}$ \\
\hline $\begin{array}{l}\text { F.G. Eddingfield Family } \\
\text { Chiropractic }\end{array}$ & $\begin{array}{l}\text { Misc. Business } \\
\text { Establishment }\end{array}$ & Small & No & $\begin{array}{l}\text { Professional } \\
\text { Services }\end{array}$ \\
\hline Barre 3- Ballet/Yoga/Pilates & $\begin{array}{l}\text { Misc. Business } \\
\text { Establishment }\end{array}$ & Small & No & $\begin{array}{l}\text { Personal } \\
\text { Services }\end{array}$ \\
\hline Street & $\begin{array}{l}\text { Number of } \\
\text { Bus Stops }\end{array}$ & $\begin{array}{l}\text { Sidewalk } \\
\text { Present? }\end{array}$ & $\begin{array}{l}\text { Bike Lane } \\
\text { Present? }\end{array}$ & $\begin{array}{l}\text { Automobile } \\
\text { Lane } \\
\text { Present? }\end{array}$ \\
\hline Franck & & Yes & No & No \\
\hline Payne & & No & No & No \\
\hline Street & $\begin{array}{l}\text { Number of } \\
\text { Bus Stops }\end{array}$ & $\begin{array}{l}\text { Sidewalk } \\
\text { Present? }\end{array}$ & $\begin{array}{l}\text { Bike Lane } \\
\text { Present? }\end{array}$ & $\begin{array}{l}\text { Automobile } \\
\text { Lane } \\
\text { Present? }\end{array}$ \\
\hline Peterson & & No & No & No \\
\hline $\begin{array}{l}\text { Establishment/ } \\
\text { Organization }\end{array}$ & $\begin{array}{l}\text { Type } \\
\text { (Ahwahnee } \\
\text { Principle } \\
\text { Category) }\end{array}$ & Size & $\begin{array}{l}\text { Unskilled } \\
\text { Jobs } \\
\text { Available? }\end{array}$ & Industry \\
\hline Barret Middle School & School & Small & No & $\begin{array}{l}\text { Educational } \\
\text { Services }\end{array}$ \\
\hline Street & $\begin{array}{l}\text { Number of } \\
\text { Bus Stops }\end{array}$ & $\begin{array}{l}\text { Sidewalk } \\
\text { Present? }\end{array}$ & $\begin{array}{l}\text { Bike Lane } \\
\text { Present? }\end{array}$ & $\begin{array}{l}\text { Automobile } \\
\text { Lane } \\
\text { Present? }\end{array}$ \\
\hline Lexington & & No & No & No \\
\hline Street & $\begin{array}{l}\text { Number of } \\
\text { Bus Stops }\end{array}$ & $\begin{array}{l}\text { Sidewalk } \\
\text { Present? }\end{array}$ & $\begin{array}{l}\text { Bike Lane } \\
\text { Present? }\end{array}$ & $\begin{array}{l}\text { Automobile } \\
\text { Lane } \\
\text { Present? }\end{array}$ \\
\hline Brownsboro & 1 & No & No & Yes \\
\hline $\begin{array}{l}\text { Establishment/ } \\
\text { Organization }\end{array}$ & Type & Size & $\begin{array}{l}\text { Unskilled } \\
\text { Jobs } \\
\text { Available? }\end{array}$ & Industry \\
\hline Penn Station & Restaurant & Small & Yes & $\begin{array}{l}\text { Personal } \\
\text { Services }\end{array}$ \\
\hline Domino’s & Restaurant & Small & Yes & $\begin{array}{l}\text { Personal } \\
\text { Services }\end{array}$ \\
\hline
\end{tabular}




\begin{tabular}{|c|c|c|c|c|}
\hline Cash Express (check cash) & $\begin{array}{l}\text { Misc. } \\
\text { Business } \\
\text { Establishment }\end{array}$ & Small & Yes & $\begin{array}{l}\text { Personal } \\
\text { Services }\end{array}$ \\
\hline Barbara Lee’s Kitchen & Restaurant & Small & Yes & $\begin{array}{l}\text { Personal } \\
\text { Services }\end{array}$ \\
\hline Deck Veterinary Services & $\begin{array}{l}\text { Misc. } \\
\text { Business } \\
\text { Establishment }\end{array}$ & Small & No & $\begin{array}{l}\text { Professional } \\
\text { Services }\end{array}$ \\
\hline Street & $\begin{array}{l}\text { Number of } \\
\text { Bus Stops }\end{array}$ & $\begin{array}{l}\text { Sidewalk } \\
\text { Present? }\end{array}$ & $\begin{array}{l}\text { Bike Lane } \\
\text { Present? }\end{array}$ & $\begin{array}{l}\text { Automobile } \\
\text { Lane } \\
\text { Present? }\end{array}$ \\
\hline Hite & & Yes & No & No \\
\hline Idlewylde & & No & No & No \\
\hline Calvin & & No & No & No \\
\hline Ewing & & No & No & No \\
\hline
\end{tabular}

Table A.4- Norton Commons’ Specific Amenities.

\begin{tabular}{|c|c|c|c|c|}
\hline Street & $\begin{array}{l}\text { Number of } \\
\text { Bus Stops }\end{array}$ & $\begin{array}{l}\text { Sidewalk } \\
\text { Present? }\end{array}$ & $\begin{array}{l}\text { Bike Lane } \\
\text { Present? }\end{array}$ & $\begin{array}{l}\text { Automobile } \\
\text { Lane } \\
\text { Present? }\end{array}$ \\
\hline Featherbell & & Yes & No & No \\
\hline $\begin{array}{l}\text { Establishment/ } \\
\text { Organization }\end{array}$ & $\begin{array}{l}\text { Type } \\
\text { (Ahwahnee } \\
\text { Principle } \\
\text { Category) }\end{array}$ & Size & $\begin{array}{l}\text { Unskilled } \\
\text { Jobs } \\
\text { Available? }\end{array}$ & $\begin{array}{l}\text { Industry } \\
\text { Type }\end{array}$ \\
\hline $\begin{array}{l}\text { Best Coins and } \\
\text { Collectibles }\end{array}$ & $\begin{array}{l}\text { Misc. Business } \\
\text { Establishment }\end{array}$ & Small & Yes & $\begin{array}{l}\text { Distributive } \\
\text { Services }\end{array}$ \\
\hline Worthington Fire Station & Misc. Civic & Small & No & $\begin{array}{l}\text { Social } \\
\text { Services }\end{array}$ \\
\hline Street & $\begin{array}{l}\text { Number of } \\
\text { Bus Stops }\end{array}$ & $\begin{array}{l}\text { Sidewalk } \\
\text { Present? }\end{array}$ & $\begin{array}{l}\text { Bike Lane } \\
\text { Present? }\end{array}$ & $\begin{array}{l}\text { Automobile } \\
\text { Lane } \\
\text { Present? }\end{array}$ \\
\hline Adams Pointe & & Yes & No & No \\
\hline Hobblebush & & Yes & No & No \\
\hline Harlequin & & Yes & No & No \\
\hline Bergamot & & Yes & No & No \\
\hline
\end{tabular}




\begin{tabular}{|c|c|c|c|c|}
\hline Street & $\begin{array}{l}\text { Number of } \\
\text { Bus Stops }\end{array}$ & $\begin{array}{l}\text { Sidewalk } \\
\text { Present? }\end{array}$ & $\begin{array}{l}\text { Bike Lane } \\
\text { Present? }\end{array}$ & $\begin{array}{l}\text { Automobile } \\
\text { Lane } \\
\text { Present? }\end{array}$ \\
\hline Meeting & & Yes & No & No \\
\hline $\begin{array}{l}\text { Establishment/ } \\
\text { Organization }\end{array}$ & $\begin{array}{l}\text { Type } \\
\text { (Ahwahnee } \\
\text { Principle } \\
\text { Category) }\end{array}$ & Size & $\begin{array}{l}\text { Unskilled } \\
\text { Jobs } \\
\text { Available? }\end{array}$ & $\begin{array}{l}\text { Industry } \\
\text { Type }\end{array}$ \\
\hline $\begin{array}{l}\text { Citizen 7- Tacos and } \\
\text { Margaritas }\end{array}$ & Restaurant & Small & Yes & $\begin{array}{l}\text { Personal } \\
\text { Services }\end{array}$ \\
\hline $\begin{array}{l}\text { Johnny Brusco’s New } \\
\text { York Style Pizza }\end{array}$ & Restaurant & Small & Yes & $\begin{array}{l}\text { Personal } \\
\text { Services }\end{array}$ \\
\hline Mercato Italiano & Restaurant & Small & Yes & $\begin{array}{l}\text { Personal } \\
\text { Services }\end{array}$ \\
\hline The 502 Bar and Bistro & Bar & Small & Yes & $\begin{array}{l}\text { Personal } \\
\text { Services }\end{array}$ \\
\hline Verbana Cafe & Restaurant & Small & Yes & $\begin{array}{l}\text { Personal } \\
\text { Services }\end{array}$ \\
\hline $\begin{array}{l}\text { Chateau Bourbon Bed and } \\
\text { Breakfast }\end{array}$ & $\begin{array}{l}\text { Misc. Business } \\
\text { Establishment }\end{array}$ & Small & Yes & $\begin{array}{l}\text { Personal } \\
\text { Services }\end{array}$ \\
\hline 7 Southern Giraffes & $\begin{array}{l}\text { Clothing } \\
\text { Store }\end{array}$ & Small & Yes & $\begin{array}{l}\text { Distributive } \\
\text { Services }\end{array}$ \\
\hline Lulubelle’s Boutique & $\begin{array}{l}\text { Clothing } \\
\text { Store }\end{array}$ & Small & Yes & $\begin{array}{l}\text { Distributive } \\
\text { Services }\end{array}$ \\
\hline The Sewing Shop & $\begin{array}{l}\text { Misc. Business } \\
\text { Establishment }\end{array}$ & Small & Yes & $\begin{array}{l}\text { Distributive } \\
\text { Services }\end{array}$ \\
\hline $\begin{array}{l}\text { Advanced Dermatology } \\
\text { and Dermaesthetics of } \\
\text { Louisville }\end{array}$ & $\begin{array}{l}\text { Misc. Business } \\
\text { Establishment }\end{array}$ & Small & No & $\begin{array}{l}\text { Professional } \\
\text { Services }\end{array}$ \\
\hline $\begin{array}{l}\text { Anderson Financial } \\
\text { Network }\end{array}$ & $\begin{array}{l}\text { Misc. Business } \\
\text { Establishment }\end{array}$ & Small & No & $\begin{array}{l}\text { Business } \\
\text { Services }\end{array}$ \\
\hline Artisan Signature Homes & $\begin{array}{l}\text { Misc. Business } \\
\text { Establishment }\end{array}$ & Small & No & Construction \\
\hline $\begin{array}{l}\text { Atkins and Atkins } \\
\text { Attorneys }\end{array}$ & $\begin{array}{l}\text { Misc. Business } \\
\text { Establishment }\end{array}$ & Small & No & $\begin{array}{l}\text { Professional } \\
\text { Services }\end{array}$ \\
\hline $\begin{array}{l}\text { Clinical Audiology of } \\
\text { Louisville }\end{array}$ & $\begin{array}{l}\text { Misc. Business } \\
\text { Establishment }\end{array}$ & Small & No & $\begin{array}{l}\text { Professional } \\
\text { Services }\end{array}$ \\
\hline $\begin{array}{l}\text { CMTA Consulting } \\
\text { Engineers }\end{array}$ & $\begin{array}{l}\text { Misc. Business } \\
\text { Establishment }\end{array}$ & Small & No & $\begin{array}{l}\text { Professional } \\
\text { Services }\end{array}$ \\
\hline $\begin{array}{l}\text { Commonwealth Bank and } \\
\text { Trust }\end{array}$ & $\begin{array}{l}\text { Misc. Business } \\
\text { Establishment }\end{array}$ & Small & No & $\begin{array}{l}\text { Business } \\
\text { Services }\end{array}$ \\
\hline $\begin{array}{l}\text { First Liberty Financial } \\
\text { Mortgage }\end{array}$ & $\begin{array}{l}\text { Misc. Business } \\
\text { Establishment }\end{array}$ & Small & No & $\begin{array}{l}\text { Business } \\
\text { Services }\end{array}$ \\
\hline $\begin{array}{l}\text { Freeman and Associates } \\
\text { Certified Public } \\
\text { Accountants }\end{array}$ & $\begin{array}{l}\text { Misc. Business } \\
\text { Establishment }\end{array}$ & Small & No & $\begin{array}{l}\text { Business } \\
\text { Services }\end{array}$ \\
\hline
\end{tabular}




\begin{tabular}{|c|c|c|c|c|}
\hline Jill M. Luckett Dentistry & $\begin{array}{l}\text { Misc. Business } \\
\text { Establishment }\end{array}$ & Small & No & $\begin{array}{l}\text { Professional } \\
\text { Services }\end{array}$ \\
\hline Kentucky Arts Academy & School & Small & No & $\begin{array}{l}\text { Educational } \\
\text { Services }\end{array}$ \\
\hline Kidz Life Pediatrics & $\begin{array}{l}\text { Misc. Business } \\
\text { Establishment }\end{array}$ & Small & No & $\begin{array}{l}\text { Professional } \\
\text { Services }\end{array}$ \\
\hline $\begin{array}{l}\text { Legacy Financial Group } \\
\text { LLC }\end{array}$ & $\begin{array}{l}\text { Misc. Business } \\
\text { Establishment }\end{array}$ & Small & No & $\begin{array}{l}\text { Business } \\
\text { Services }\end{array}$ \\
\hline Minnick Media & $\begin{array}{l}\text { Misc. Business } \\
\text { Establishment }\end{array}$ & Small & No & $\begin{array}{l}\text { Business } \\
\text { Services }\end{array}$ \\
\hline Northeast Barbers & $\begin{array}{l}\text { Misc. Business } \\
\text { Establishment }\end{array}$ & Small & No & $\begin{array}{l}\text { Personal } \\
\text { Services }\end{array}$ \\
\hline $\begin{array}{l}\text { Norton Commons Realty } \\
\text { LLC }\end{array}$ & $\begin{array}{l}\text { Misc. Business } \\
\text { Establishment }\end{array}$ & Small & No & $\begin{array}{l}\text { Business } \\
\text { Services }\end{array}$ \\
\hline $\begin{array}{l}\text { Onsite Health Solutions } \\
\text { LLC }\end{array}$ & $\begin{array}{l}\text { Misc. Business } \\
\text { Establishment }\end{array}$ & Small & No & $\begin{array}{l}\text { Professional } \\
\text { Services }\end{array}$ \\
\hline Premiere Flooring & $\begin{array}{l}\text { Misc. Business } \\
\text { Establishment }\end{array}$ & Small & No & $\begin{array}{l}\text { Distributive } \\
\text { Services }\end{array}$ \\
\hline $\begin{array}{l}\text { Salon Muse and Blow Dry } \\
\text { Lounge }\end{array}$ & $\begin{array}{l}\text { Misc. Business } \\
\text { Establishment }\end{array}$ & Small & No & $\begin{array}{l}\text { Personal } \\
\text { Services }\end{array}$ \\
\hline State Farm Insurance & $\begin{array}{l}\text { Misc. Business } \\
\text { Establishment }\end{array}$ & Small & No & $\begin{array}{l}\text { Business } \\
\text { Services }\end{array}$ \\
\hline $\begin{array}{l}\text { Turner, Keal and Dallas } \\
\text { PLLC }\end{array}$ & $\begin{array}{l}\text { Misc. Business } \\
\text { Establishment }\end{array}$ & Small & No & $\begin{array}{l}\text { Professional } \\
\text { Services }\end{array}$ \\
\hline $\begin{array}{l}\text { Valhalla Dental Care at } \\
\text { Norton Commons }\end{array}$ & $\begin{array}{l}\text { Misc. Business } \\
\text { Establishment }\end{array}$ & Small & No & $\begin{array}{l}\text { Professional } \\
\text { Services }\end{array}$ \\
\hline $\begin{array}{l}\text { Witzke Studios at Norton } \\
\text { Commons (professional } \\
\text { photography) }\end{array}$ & $\begin{array}{l}\text { Misc. Business } \\
\text { Establishment }\end{array}$ & Small & No & $\begin{array}{l}\text { Personal } \\
\text { Services }\end{array}$ \\
\hline Street & $\begin{array}{l}\text { Number of } \\
\text { Bus Stops }\end{array}$ & $\begin{array}{l}\text { Sidewalk } \\
\text { Present? }\end{array}$ & $\begin{array}{l}\text { Bike Lane } \\
\text { Present? }\end{array}$ & $\begin{array}{l}\text { Automobile } \\
\text { Lane } \\
\text { Present? }\end{array}$ \\
\hline Kings Crowne & & Yes & No & No \\
\hline $\begin{array}{l}\text { Establishment/ } \\
\text { Organization }\end{array}$ & $\begin{array}{l}\text { Type } \\
\text { (Ahwahnee } \\
\text { Principle } \\
\text { Category) }\end{array}$ & Size & $\begin{array}{l}\text { Unskilled } \\
\text { Jobs } \\
\text { Available? }\end{array}$ & $\begin{array}{l}\text { Industry } \\
\text { Type }\end{array}$ \\
\hline $\begin{array}{l}\text { Norton Commons } \\
\text { Elementary School }\end{array}$ & School & Small & No & $\begin{array}{l}\text { Educational } \\
\text { Services }\end{array}$ \\
\hline Street & $\begin{array}{l}\text { Number of } \\
\text { Bus Stops }\end{array}$ & $\begin{array}{l}\text { Sidewalk } \\
\text { Present? }\end{array}$ & $\begin{array}{l}\text { Bike Lane } \\
\text { Present? }\end{array}$ & $\begin{array}{l}\text { Automobile } \\
\text { Lane } \\
\text { Present? }\end{array}$ \\
\hline Moonseed & & No & No & No \\
\hline Mayapple & & Yes & No & No \\
\hline
\end{tabular}




\begin{tabular}{|c|c|c|c|c|}
\hline Peppermint & & Yes & No & No \\
\hline Mistflower & & No & No & No \\
\hline Street & $\begin{array}{l}\text { Number of } \\
\text { Bus Stops }\end{array}$ & $\begin{array}{l}\text { Sidewalk } \\
\text { Present? }\end{array}$ & $\begin{array}{l}\text { Bike Lane } \\
\text { Present? }\end{array}$ & $\begin{array}{l}\text { Automobile } \\
\text { Lane } \\
\text { Present? }\end{array}$ \\
\hline $\begin{array}{l}\text { Norton Commons } \\
\text { Boulevard }\end{array}$ & & Yes & No & Yes \\
\hline Establishment/Organization & $\begin{array}{l}\text { Type } \\
\text { (Ahwahnee } \\
\text { Principle } \\
\text { Category) } \\
\end{array}$ & Size & $\begin{array}{l}\text { Unskilled } \\
\text { Jobs } \\
\text { Available? }\end{array}$ & $\begin{array}{l}\text { Industry } \\
\text { Type }\end{array}$ \\
\hline Commonwealth Tap & Bar & Small & Yes & $\begin{array}{l}\text { Personal } \\
\text { Services }\end{array}$ \\
\hline Gelato Gilberto & Restaurant & Small & Yes & $\begin{array}{l}\text { Personal } \\
\text { Services }\end{array}$ \\
\hline Karem’s Grill and Pub & Restaurant & Small & Yes & $\begin{array}{l}\text { Personal } \\
\text { Services }\end{array}$ \\
\hline Legend of China & Restaurant & Small & Yes & $\begin{array}{l}\text { Personal } \\
\text { Services }\end{array}$ \\
\hline $\begin{array}{l}\text { Meeting Street Coffee } \\
\text { House }\end{array}$ & Restaurant & Small & Yes & $\begin{array}{l}\text { Personal } \\
\text { Services }\end{array}$ \\
\hline Tea Asian Bistro & Restaurant & Small & Yes & $\begin{array}{l}\text { Personal } \\
\text { Services }\end{array}$ \\
\hline Cale and Cole (jewelry) & $\begin{array}{l}\text { Misc. } \\
\text { Business } \\
\text { Establishment }\end{array}$ & Small & Yes & $\begin{array}{l}\text { Distributive } \\
\text { Services }\end{array}$ \\
\hline $\begin{array}{l}\text { Commons Community } \\
\text { Pharmacy }\end{array}$ & $\begin{array}{l}\text { Convenience } \\
\text { Store/Drug } \\
\text { Store }\end{array}$ & Small & Yes & $\begin{array}{l}\text { Distributive } \\
\text { Services }\end{array}$ \\
\hline $\begin{array}{l}\text { Saratoga's Accessories and } \\
\text { Design }\end{array}$ & $\begin{array}{l}\text { Misc. } \\
\text { Business } \\
\text { Establishment }\end{array}$ & Small & Yes & $\begin{array}{l}\text { Distributive } \\
\text { Services }\end{array}$ \\
\hline $\begin{array}{l}\text { Something Blue (wedding } \\
\text { accessories) }\end{array}$ & $\begin{array}{l}\text { Misc. } \\
\text { Business } \\
\text { Establishment }\end{array}$ & Small & Yes & $\begin{array}{l}\text { Distributive } \\
\text { Services }\end{array}$ \\
\hline Belleza Family Salon & $\begin{array}{l}\text { Misc. } \\
\text { Business } \\
\text { Establishment }\end{array}$ & Small & No & $\begin{array}{l}\text { Personal } \\
\text { Services }\end{array}$ \\
\hline $\begin{array}{l}\text { Burrus Architecture and } \\
\text { Construction LLC }\end{array}$ & $\begin{array}{l}\text { Misc. } \\
\text { Business } \\
\text { Establishment }\end{array}$ & Small & No & $\begin{array}{l}\text { Professional } \\
\text { Services }\end{array}$ \\
\hline Cores Pilates and Yoga & $\begin{array}{l}\text { Misc. Business } \\
\text { Establishment }\end{array}$ & Small & No & $\begin{array}{l}\text { Personal } \\
\text { Services } \\
\end{array}$ \\
\hline Draped in Style & $\begin{array}{l}\text { Misc. Business } \\
\text { Establishment }\end{array}$ & Small & Yes & $\begin{array}{l}\text { Distributive } \\
\text { Services }\end{array}$ \\
\hline
\end{tabular}




\begin{tabular}{|c|c|c|c|c|}
\hline Enesa Skin Institute & $\begin{array}{l}\text { Misc. Business } \\
\text { Establishment }\end{array}$ & Small & No & $\begin{array}{l}\text { Professional } \\
\text { Services }\end{array}$ \\
\hline T-Town Nails & $\begin{array}{l}\text { Misc. Business } \\
\text { Establishment }\end{array}$ & Small & No & $\begin{array}{l}\text { Personal } \\
\text { Services } \\
\end{array}$ \\
\hline $\begin{array}{l}\text { The Gleason Group } \\
\text { (financial services) }\end{array}$ & $\begin{array}{l}\text { Misc. Business } \\
\text { Establishment }\end{array}$ & Small & No & $\begin{array}{l}\text { Business } \\
\text { Services }\end{array}$ \\
\hline $\begin{array}{l}\text { The Pet Station Salon and } \\
\text { Boutique }\end{array}$ & $\begin{array}{l}\text { Misc. Business } \\
\text { Establishment }\end{array}$ & Small & No & $\begin{array}{l}\text { Personal } \\
\text { Services }\end{array}$ \\
\hline Thomas Law Offices & $\begin{array}{l}\text { Misc. Business } \\
\text { Establishment }\end{array}$ & Small & No & $\begin{array}{l}\text { Professional } \\
\text { Services }\end{array}$ \\
\hline Town Family Doctor & $\begin{array}{l}\text { Misc. Business } \\
\text { Establishment }\end{array}$ & Small & No & $\begin{array}{l}\text { Professional } \\
\text { Services }\end{array}$ \\
\hline Street & $\begin{array}{l}\text { Number of } \\
\text { Bus Stops }\end{array}$ & $\begin{array}{l}\text { Sidewalk } \\
\text { Present? }\end{array}$ & $\begin{array}{l}\text { Bike Lane } \\
\text { Present? }\end{array}$ & $\begin{array}{l}\text { Automobile } \\
\text { Lane } \\
\text { Present? }\end{array}$ \\
\hline Impaticus & & Yes & No & No \\
\hline Jimson & & Yes & No & No \\
\hline Street & $\begin{array}{l}\text { Number of } \\
\text { Bus Stops }\end{array}$ & $\begin{array}{l}\text { Sidewalk } \\
\text { Present? }\end{array}$ & $\begin{array}{l}\text { Bike Lane } \\
\text { Present? }\end{array}$ & $\begin{array}{l}\text { Automobile } \\
\text { Lane } \\
\text { Present? }\end{array}$ \\
\hline Dayflower & & Yes & No & No \\
\hline $\begin{array}{l}\text { Establishment/ } \\
\text { Organization }\end{array}$ & $\begin{array}{l}\text { Type } \\
\text { (Ahwahnee } \\
\text { Principle } \\
\text { Category) }\end{array}$ & Size & $\begin{array}{l}\text { Unskilled } \\
\text { Jobs } \\
\text { Available? }\end{array}$ & $\begin{array}{l}\text { Industry } \\
\text { Type }\end{array}$ \\
\hline $\begin{array}{l}\text { Cassis Dermatology and } \\
\text { Aesthetics Center }\end{array}$ & $\begin{array}{l}\text { Misc. Business } \\
\text { Establishment }\end{array}$ & Small & No & $\begin{array}{l}\text { Professional } \\
\text { Services }\end{array}$ \\
\hline $\begin{array}{l}\text { Goldberg and Simpson } \\
\text { Attorneys }\end{array}$ & $\begin{array}{l}\text { Misc. Business } \\
\text { Establishment }\end{array}$ & Small & No & $\begin{array}{l}\text { Professional } \\
\text { Services }\end{array}$ \\
\hline The Vanguard Academy & School & Small & No & $\begin{array}{l}\text { Educational } \\
\text { Services }\end{array}$ \\
\hline Street & $\begin{array}{l}\text { Number of } \\
\text { Bus Stops }\end{array}$ & $\begin{array}{l}\text { Sidewalk } \\
\text { Present? }\end{array}$ & $\begin{array}{l}\text { Bike Lane } \\
\text { Present? }\end{array}$ & $\begin{array}{l}\text { Automobile } \\
\text { Lane } \\
\text { Present? }\end{array}$ \\
\hline Cranesbill & & Yes & No & No \\
\hline Angel Trumpet & & Yes & No & No \\
\hline Delphinium & & Yes & No & No \\
\hline Catfoot & & Yes & No & No \\
\hline Civic & & Yes & No & No \\
\hline Ceralda & & Yes & No & No \\
\hline
\end{tabular}




\begin{tabular}{|l|l|l|l|l|}
\hline Street & $\begin{array}{l}\text { Number of } \\
\text { Bus Stops }\end{array}$ & $\begin{array}{l}\text { Sidewalk } \\
\text { Present? }\end{array}$ & $\begin{array}{l}\text { Bike Lane } \\
\text { Present? }\end{array}$ & $\begin{array}{l}\text { Automobile } \\
\text { Lane } \\
\text { Present? }\end{array}$ \\
\hline Saint Bernadette Avenue & & Yes & No & No \\
\hline $\begin{array}{l}\text { Establishment/ } \\
\text { Organization }\end{array}$ & $\begin{array}{l}\text { Type } \\
\text { (Ahwahnee } \\
\text { Principle } \\
\text { Category) }\end{array}$ & Size & $\begin{array}{l}\text { Unskilled } \\
\text { Jobs } \\
\text { Available? }\end{array}$ & $\begin{array}{l}\text { Industry } \\
\text { Type }\end{array}$ \\
\hline Saint Bernadette Church & Misc. Civic & Small & No & Other \\
\hline Street & $\begin{array}{l}\text { Number of } \\
\text { Bus Stops }\end{array}$ & $\begin{array}{l}\text { Sidewalk } \\
\text { Present? }\end{array}$ & $\begin{array}{l}\text { Bike Lane } \\
\text { Present? }\end{array}$ & $\begin{array}{l}\text { Automobile } \\
\text { Lane } \\
\text { Present? }\end{array}$ \\
\hline Saint Mary Lane & $\begin{array}{l}\text { Type } \\
\text { (Ahwahnee } \\
\text { Principle } \\
\text { Category) }\end{array}$ & Size & $\begin{array}{l}\text { No } \\
\text { Onskilled } \\
\text { Jobs } \\
\text { Available? }\end{array}$ & $\begin{array}{l}\text { Industry } \\
\text { Type }\end{array}$ \\
\hline Saint Mary Academy & School & Small & No & $\begin{array}{l}\text { Educational } \\
\text { Services }\end{array}$ \\
\hline $\begin{array}{l}\text { Establishment/ } \\
\text { Organization }\end{array}$ & $\begin{array}{l}\text { Type } \\
\text { (Ahwahnee } \\
\text { Principle } \\
\text { Category) }\end{array}$ & Size & $\begin{array}{l}\text { Unskilled } \\
\text { Jobs } \\
\text { Available? }\end{array}$ & $\begin{array}{l}\text { Industry } \\
\text { Type }\end{array}$ \\
\hline YMCA & Misc. Civic & Small & No & $\begin{array}{l}\text { Personal } \\
\text { Services }\end{array}$ \\
\hline Amphitheater & Misc. Civic & Small & $\begin{array}{l}\text { Yes } \\
\text { Sersonal }\end{array}$ \\
\hline
\end{tabular}

Table A.5- Specific Amenities for Suburban Shopping Area South of Norton Commons.

\begin{tabular}{|l|l|l|l|l|}
\hline Street & $\begin{array}{l}\text { Number of Bus } \\
\text { Stops }\end{array}$ & $\begin{array}{l}\text { Sidewalk } \\
\text { Present? }\end{array}$ & $\begin{array}{l}\text { Bike Lane } \\
\text { Present? }\end{array}$ & $\begin{array}{l}\text { Automobile } \\
\text { Lane } \\
\text { Present? }\end{array}$ \\
\hline Summit Park Plaza & & Yes & No & No \\
\hline Telford Lane & & Yes & No & Yes \\
\hline Chamberlain Lane & & No & No & Yes \\
\hline Glasgow Blvd. & & No & No & No \\
\hline Cottonhole Place & & No & No & No \\
\hline Magdalen Square & & No & No & No \\
\hline Tanton Square & & No & No & No \\
\hline
\end{tabular}




\begin{tabular}{|c|c|c|c|c|}
\hline US Highway 1094 & & No & No & Yes \\
\hline Street & $\begin{array}{l}\text { Number of Bus } \\
\text { Stops }\end{array}$ & $\begin{array}{l}\text { Sidewalk } \\
\text { Present? }\end{array}$ & $\begin{array}{l}\text { Bike Lane } \\
\text { Present? }\end{array}$ & $\begin{array}{l}\text { Automobile } \\
\text { Lane } \\
\text { Present? }\end{array}$ \\
\hline $\begin{array}{l}\text { Brownsboro from } \\
\text { Chamberlain to } \\
\text { Highway } 1094\end{array}$ & 1 & Yes & No & Yes \\
\hline $\begin{array}{l}\text { Establishment/ } \\
\text { Organization }\end{array}$ & $\begin{array}{l}\text { Type (Ahwahnee } \\
\text { Principle } \\
\text { Category) }\end{array}$ & Size & $\begin{array}{l}\text { Unskilled } \\
\text { Jobs } \\
\text { Available? }\end{array}$ & $\begin{array}{l}\text { Industry } \\
\text { Type }\end{array}$ \\
\hline Walgreen's & $\begin{array}{l}\text { Convenience/Drug } \\
\text { Store }\end{array}$ & Small & Yes & $\begin{array}{l}\text { Distributive } \\
\text { Services }\end{array}$ \\
\hline $\begin{array}{l}\text { Family Allergy and } \\
\text { Asthma }\end{array}$ & $\begin{array}{l}\text { Misc. Business } \\
\text { Establishment }\end{array}$ & Small & No & $\begin{array}{l}\text { Professional } \\
\text { Services }\end{array}$ \\
\hline $\begin{array}{l}\text { Growing Healthy } \\
\text { Children }\end{array}$ & $\begin{array}{l}\text { Misc. Business } \\
\text { Establishment }\end{array}$ & Small & No & $\begin{array}{l}\text { Professional } \\
\text { Services }\end{array}$ \\
\hline $\begin{array}{l}\text { Brownsboro Road } \\
\text { Pediatric }\end{array}$ & $\begin{array}{l}\text { Misc. Business } \\
\text { Establishment }\end{array}$ & Small & No & $\begin{array}{l}\text { Professional } \\
\text { Services }\end{array}$ \\
\hline Nail Spa & $\begin{array}{l}\text { Misc. Business } \\
\text { Establishment }\end{array}$ & Small & No & $\begin{array}{l}\text { Personal } \\
\text { Services }\end{array}$ \\
\hline $\begin{array}{l}\text { Home Now Medical } \\
\text { Supplies }\end{array}$ & $\begin{array}{l}\text { Misc. Business } \\
\text { Establishmnt }\end{array}$ & Small & Yes & $\begin{array}{l}\text { Distributive } \\
\text { Services }\end{array}$ \\
\hline $\begin{array}{l}\text { First Capital Bank of } \\
\text { Kentucky }\end{array}$ & $\begin{array}{l}\text { Misc. Business } \\
\text { Establishment }\end{array}$ & Small & No & $\begin{array}{l}\text { Business } \\
\text { Services }\end{array}$ \\
\hline Cardinal Uniforms & $\begin{array}{l}\text { Misc. Business } \\
\text { Establishment }\end{array}$ & Small & Yes & $\begin{array}{l}\text { Distributive } \\
\text { Services }\end{array}$ \\
\hline $\begin{array}{l}\text { Springhurst Animal } \\
\text { Hospital }\end{array}$ & $\begin{array}{l}\text { Misc. Business } \\
\text { Establishment }\end{array}$ & Small & No & $\begin{array}{l}\text { Professional } \\
\text { Services }\end{array}$ \\
\hline Dunkin Donuts & Restaurant & Small & Yes & $\begin{array}{l}\text { Personal } \\
\text { Services }\end{array}$ \\
\hline Speedway & $\begin{array}{l}\text { Convenience/Drug } \\
\text { Store }\end{array}$ & Small & Yes & $\begin{array}{l}\text { Distributive } \\
\text { Services }\end{array}$ \\
\hline Iron Tribe Fitness & $\begin{array}{l}\text { Misc. Business } \\
\text { Establishment }\end{array}$ & Small & No & $\begin{array}{l}\text { Personal } \\
\text { Services }\end{array}$ \\
\hline Red Robin & Restaurant & Small & Yes & $\begin{array}{l}\text { Personal } \\
\text { Services } \\
\end{array}$ \\
\hline $\begin{array}{l}\text { Norton Brownsboro } \\
\text { Hospital }\end{array}$ & $\begin{array}{l}\text { Misc. Business } \\
\text { Establishment }\end{array}$ & Medium & No & $\begin{array}{l}\text { Professional } \\
\text { Services }\end{array}$ \\
\hline Thornton’s & $\begin{array}{l}\text { Convenience/Drug } \\
\text { Store }\end{array}$ & Small & Yes & $\begin{array}{l}\text { Distributive } \\
\text { Services }\end{array}$ \\
\hline $\begin{array}{l}\text { Worthington } \\
\text { Cemetery }\end{array}$ & Misc. Civic & Small & Yes & $\begin{array}{l}\text { Personal } \\
\text { Services }\end{array}$ \\
\hline $\begin{array}{l}\text { Ken Towery's } \\
\text { AutoCare }\end{array}$ & $\begin{array}{l}\text { Misc. Business } \\
\text { Establishment }\end{array}$ & Small & No & $\begin{array}{l}\text { Personal } \\
\text { Services }\end{array}$ \\
\hline
\end{tabular}




\begin{tabular}{|l|l|l|l|l|}
\hline $\begin{array}{l}\text { Casa Gusta Mexican } \\
\text { Restaurant }\end{array}$ & Restaurant & Small & Yes & $\begin{array}{l}\text { Personal } \\
\text { Services }\end{array}$ \\
\hline $\begin{array}{l}\text { Sam Meyer's Dry } \\
\text { Cleaners }\end{array}$ & $\begin{array}{l}\text { Misc. Business } \\
\text { Establishment }\end{array}$ & Small & Yes & $\begin{array}{l}\text { Personal } \\
\text { Services }\end{array}$ \\
\hline Custom 502 Pizza & $\begin{array}{l}\text { Misc. Business } \\
\text { Establishment }\end{array}$ & Small & Yes & $\begin{array}{l}\text { Personal } \\
\text { Services }\end{array}$ \\
\hline Ollis Chiropractic & $\begin{array}{l}\text { Misc. Business } \\
\text { Establishment }\end{array}$ & Small & No & $\begin{array}{l}\text { Professional } \\
\text { Services }\end{array}$ \\
\hline $\begin{array}{l}\text { Edward Jones } \\
\text { Financial Planning }\end{array}$ & $\begin{array}{l}\text { Misc. Business } \\
\text { Establishment }\end{array}$ & Small & No & $\begin{array}{l}\text { Business } \\
\text { Services }\end{array}$ \\
\hline $\begin{array}{l}\text { Northeast Barber } \\
\text { Shop }\end{array}$ & $\begin{array}{l}\text { Misc. Business } \\
\text { Establishment }\end{array}$ & Small & No & $\begin{array}{l}\text { Personal } \\
\text { Services }\end{array}$ \\
\hline Cornerstone Dental & $\begin{array}{l}\text { Misc. Business } \\
\text { Establishment }\end{array}$ & Small & No & $\begin{array}{l}\text { Professional } \\
\text { Services }\end{array}$ \\
\hline $\begin{array}{l}\text { Kentuckiana Medical } \\
\text { Weight Loss Center }\end{array}$ & $\begin{array}{l}\text { Misc. Business } \\
\text { Establishment }\end{array}$ & Small & No & $\begin{array}{l}\text { Professional } \\
\text { Services }\end{array}$ \\
\hline $\begin{array}{l}\text { Northeast Christian } \\
\text { Church }\end{array}$ & Misc. Civic & Small & No & Other \\
\hline
\end{tabular}

Table A.6- Wolf Trace Subdivision's Specific Amenities.

\begin{tabular}{|l|l|l|l|l|}
\hline Street & $\begin{array}{l}\text { Number } \\
\text { of Bus } \\
\text { Stops }\end{array}$ & $\begin{array}{l}\text { Sidewalk } \\
\text { Present? }\end{array}$ & $\begin{array}{l}\text { Bike Lane } \\
\text { Present? }\end{array}$ & $\begin{array}{l}\text { Automobile Lane } \\
\text { Present? }\end{array}$ \\
\hline Bingham View & & Yes & No & No \\
\hline Waveland & & Yes & No & No \\
\hline Horton & & Yes & No & No \\
\hline Chamberlain Drive & & Yes & No & Yes \\
\hline Hensley & & Yes & No & No \\
\hline Merribrook & & Yes & No & No \\
\hline Mozart & & Yes & No & No \\
\hline Tuscott Falls & & Yes & No & No \\
\hline
\end{tabular}




\section{APPRENDIX B}

\section{CENSUS TRACTS WITHIN TRANSIT RANGE FOR CLIFTON AND NORTON COMMONS}

The tables below contain the census tracts used for the regional comparison of Chapter VII, as well as the median household income, and total number of households for these census tracts. Income has been rounded to the nearest thousand, as exact averages are not part of the calculations. The first table has data for the census tracts within Clifton's transit range, while the second table has data for the census tracts within Norton Common's transit range. As explained in Chapter IV, the transit range is comprised of a half-circle within a five-mile radius to the south of Clifton, and a half-circle within a fivemile radius to the west of Norton Commons. Justification for this range has been provided in the methodology chapter, Chapter, IV.

Table B.1- Census Tracts within Transit Range of Clifton.

\begin{tabular}{|l|l|l|}
\hline Census Tract & Median Household Income & Total Households \\
\hline 24 & $19 \mathrm{k}$ & 2,018 \\
\hline 27 & $23 \mathrm{k}$ & 1,152 \\
\hline 30 & $9 \mathrm{k}$ & 1,312 \\
\hline 49 & $16 \mathrm{k}$ & 1,538 \\
\hline 51 & $37 \mathrm{k}$ & 2,258 \\
\hline
\end{tabular}




\begin{tabular}{|c|c|c|}
\hline 52 & $28 \mathrm{k}$ & 1,966 \\
\hline 59 & $25 \mathrm{k}$ & 2,361 \\
\hline 63 & $37 \mathrm{k}$ & 876 \\
\hline 84 & $54 \mathrm{k}$ & 848 \\
\hline 65 & $21 \mathrm{k}$ & 1,157 \\
\hline 66 & $30 \mathrm{k}$ & 999 \\
\hline 69 & $38 \mathrm{k}$ & 972 \\
\hline 70 & $49 k$ & 384 \\
\hline 71 & $31 \mathrm{k}$ & 2,090 \\
\hline 82 & $73 \mathrm{k}$ & 548 \\
\hline 83 & $63 \mathrm{k}$ & 1,246 \\
\hline 84 & $93 \mathrm{k}$ & 652 \\
\hline 85 & $60 \mathrm{k}$ & 1,107 \\
\hline 88 & $73 \mathrm{k}$ & 1,505 \\
\hline 89 & $95 \mathrm{k}$ & 1,594 \\
\hline 93 & $64 \mathrm{k}$ & 2,195 \\
\hline 94 & $71 \mathrm{k}$ & 2,789 \\
\hline 96 & $84 \mathrm{k}$ & 1,369 \\
\hline 97 & $74 \mathrm{k}$ & 1,278 \\
\hline 105 & $91 \mathrm{k}$ & 694 \\
\hline 106.01 & $73 \mathrm{k}$ & 1,524 \\
\hline 106.02 & $65 \mathrm{k}$ & 2,372 \\
\hline 108 & $64 \mathrm{k}$ & 1,531 \\
\hline 109.02 & $52 \mathrm{k}$ & 1,107 \\
\hline 110.02 & $26 \mathrm{k}$ & 2,342 \\
\hline 110.03 & $43 \mathrm{k}$ & 2,691 \\
\hline 110.04 & $41 \mathrm{k}$ & 2,873 \\
\hline 112 & $26 \mathrm{k}$ & 1,104 \\
\hline 113.01 & $30 \mathrm{k}$ & 994 \\
\hline 114.04 & $30 \mathrm{k}$ & 1,477 \\
\hline 128.02 & $30 \mathrm{k}$ & 1,081 \\
\hline
\end{tabular}

Table B.2- Census Tracts within Transit Range of Norton Commons.

\begin{tabular}{|l|l|l|}
\hline Census Tract & Median Household Income & Total Households \\
\hline 103.17 & $112 \mathrm{k}$ & 1,439 \\
\hline 103.18 & $86 \mathrm{k}$ & 2,524 \\
\hline 103.19 & $70 \mathrm{k}$ & 1,829 \\
\hline
\end{tabular}




\begin{tabular}{|l|l|l|}
\hline 104.03 & $84 \mathrm{k}$ & 1,568 \\
\hline 103.13 & $104 \mathrm{k}$ & 1,288 \\
\hline 101.03 & $45 \mathrm{k}$ & 2,021 \\
\hline 103.09 & $95 \mathrm{k}$ & 1,936 \\
\hline 100.05 & $52 \mathrm{k}$ & 1,740 \\
\hline 100.06 & $51 \mathrm{k}$ & 1,580 \\
\hline 100.07 & $86 \mathrm{k}$ & 1,551 \\
\hline 100.08 & $53 \mathrm{k}$ & 1,611 \\
\hline 75.02 & $110 \mathrm{k}$ & 2,094 \\
\hline 510 & $36 \mathrm{k}$ & 776 \\
\hline 307.01 & $136 \mathrm{k}$ & 760 \\
\hline 307.02 & $111 \mathrm{k}$ & 1,715 \\
\hline 306.02 & $75 \mathrm{k}$ & 2,106 \\
\hline
\end{tabular}

(Source: United States Census Bureau) 


\title{
CURRICULUM VITAE
}

\author{
Aaron Stephenson \\ 6404 Fern Valley Way, Apt. 6, Louisville, Kentucky, 40219 \\ 859.963.6909 \\ aaron.stephenson@louisville.edu
}

\section{EDUCATION}

Doctor of Philosophy, Urban and Public Affairs-December 2017

University of Louisville, Kentucky

Dissertation: Norton Commons, Clifton, and Social Equity: A Neighborhood, Inter-

Neighborhood, and Regional Comparison of New Urbanism and "Old" Urbanism

Masters in the Art of Teaching-2012

Spalding University, Kentucky

Concentration: Middle and Secondary English

Bachelor of Arts in English-2007

University of Kentucky, Kentucky

\section{FIELDS OF SPECIALIZATION}

New Urbanism, Social Equity, Urban Planning and Sustainability, Workplace Insubordination, Grassroots/Neighborhood Organization

\section{RESEARCH}

\section{Ongoing Research}

1. The Place of New Urbanism: A Macro-Level loo at New Urbanism and what Type of Cities New Urbanism Proliferate. Aaron Stephenson.

2. The Tautology of New Urbanism. Aaron Stephenson.

3. Donald, C. \& Stephenson, A. Insubordination in the Workplace: Arbitrators and Application of Workplace Standards.

4. Theft in the Workplace. Carrie Donald and Aaron Stephenson.

5. Safety and Health in the Workplace. Carrie Donald and Aaron Stephenson. 


\section{TEACHING EXPERIENCE}

Student Teacher-Middle School and High School English (Spring 2012)

Conway Middle School and Liberty High School

Louisville, Kentucky

Instructor-Urban Politics (Spring 2017)

Political Science Department

University of Louisville, Kentucky

\section{PRESENTATIONS}

1. "Insubordination in the Workplace: Arbitrators and the Application of Just Cause Standards", paper presented at the Annual Labor and Employment Relations Association Conference, Portland, OR, 2014 (Co-author: Carrie Donald).

2. "Theft in the Workplace" paper presented at the Annual UALE Conference, Orlando Florida, 2015 (Co-author: Carrie Donald).

3. "Safety and Health in the Workplace" presented at the Annual Labor and Employment Relations Association Conference, Pittsburgh, PA, 2015 (Co-author: Carrie Donald).

4. "Theft in the Workplace", Annual UALE Conference, Washington, D.C., 2016 (Coauthor: Carrie Donald).

\section{OTHER RELEVANT WORK EXPERIENCE}

Graduate Research Assistant- 2013 to 2016

University of Louisville, Kentucky.

Conference Presentations, Qualitative Research, Document Analysis, and Administrative Support.

\section{SERVICE}

1. Graduate Student Council Representative (2013-2015), University of Louisville.

2. Clifton Community Council (2014-2015); Louisville, Kentucky.

3. Election Work for Teamsters' Local No. 783 Union Election; Louisville, Kentucky.

4. Phi Kappa Phi Honor Society Administrative Support, University of Louisville.

5. President of Urban and Public Affairs Ph.D. Student Association (2015-2016), University of Louisville. 


\section{REFERENCES}

Dr. David Imbroscio

Professor, Department of Political Science \&Urban and Public Affairs

Director, Ph.D. Program in Urban and Public Affairs

University of Louisville

426 W Bloom Street

Louisville, KY 40208

Phone: (502) 852-6005

Email: david.imbroscio@,louisville.edu

Dr. Cynthia Negrey

Professor Sociology \& Urban and Public Affairs

University of Louisville

125 Lutz Hall

Louisville, Kentucky 40292

Phone: (502) 852-8053

Email: cynthia.negrey@louisville.edu

Dr. David Simpson

Professor Urban and Public Affairs

Department Chair Urban and Public Affairs

University of Louisville

426 W Bloom Street

Louisville, KY 40208

Phone: (502) 852-8019

Email:david.simpson@louisville.edu

Jack Trawick

Instructor Urban and Public Affairs

University of Louisville

426 W Bloom Street

Louisville, Kentucky 40208

Email: jack.trawick@louisville.edu 